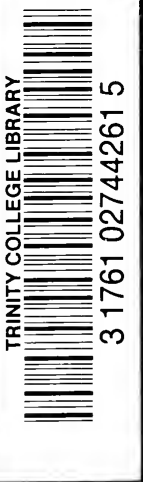




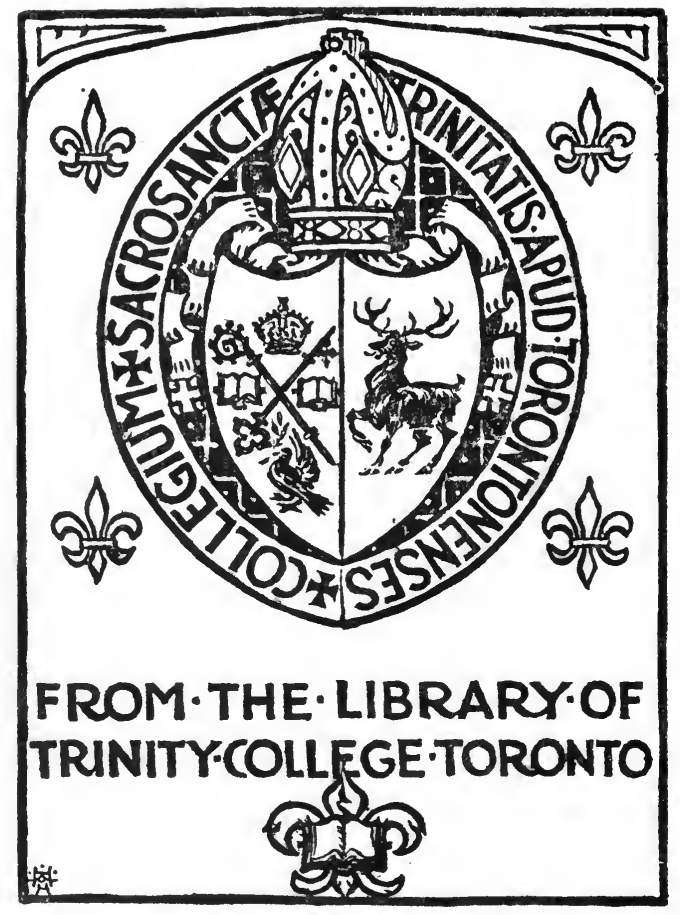

PRESENTED .... A.D. 1967 BYProfessor E.R.Fairweather 



\section{-}




\section{THE CHURCH OF ENGLAND AND EPISCOPACY}




\section{CAMBRIDGE UNIVERSITY PRESS}

C. F. CLAY, Manager

Zloñon: FETTER LANE, E.C.

jerinburgh : 100 PRINCES STREET

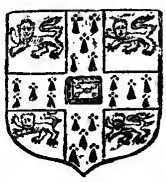

Berlin: A. ASHER AND CO.

Ileipsig: F. A. BROCKHAUS

fiew gork: G. P. PUTNAM'S SONS

bombay and Calcutta: MACMILLAN AND CO., LTD.

Toranta: J. M. DENT AND SONS, LTD.

đokno: THE MARUZEN-KABUSHIKI-KAISHA 


\title{
THE CHURCH OF ENGLAND AND EPISCOPACY
}

\author{
BY \\ A. J. MASON, D.D. \\ Honorary Fellow of Pembroke and Jesus Colleges, and formerly \\ Fellow of Trinity College, Cambridge \\ Canon of Canterbury
}

Cambridge :

at the University Press

I 9 I 4 
$B X$

$5+96$

$M=$

Cambrioge:

PRINTED BY JOHN CLAY, M.A.

AT THE UNIVERSITY PRESS

$\operatorname{arT} 131967$

$-75.58$ 
TO THE MOST REVEREND FATHER IN GOD

\section{RANDALL}

CALLED BY DIVINE PROVIDENCE TO BE ARCHBISHOP OF CANTERBURY AND

PRIMATE OF ALL ENGLAND

AT A TIME WHICH PECULIARLY NEEDS

THOSE GIFTS OF COURAGE AND CAUTION, OF LARGENESS OF MIND AND FIRMNESS OF PRINCIPLE, WITH WHICH IT HAS PLEASED GOD TO ENDOW HIM. 



\section{PREFACE}

WHEN tidings reached England of the now famous conference of last year at Kikuyu, and of the offence taken at it by the Bishop of Zanzibar, it became my duty to investigate certain points in the controversy on behalf of the Archbishop of Canterbury, whose chaplain I have the honour to be. Encouraged by some kind words that fell from his Grace in that connexion, I was drawn on into putting together a kind of catena of passages from Anglican writers, from the Reformation to the Catholic Revival of the nineteenth century, for the purpose of showing their views on the origin, the sanction, and the obligation of episcopacy, and on the position which we ought to hold in relation to non-episcopal communities both abroad and at home. That was the origin of this book. I need not say that his Grace is not committed to a single expression in it except those taken from formularies to which the whole church of England is pledged. It is, however, 
humbly offered as a contribution towards the solution of questions which the Kikuyu Conference has raised, and to which an authoritative answer has been promised.

It is by no means the first time that a collection of this kind has been attempted. Some writers have endeavoured to prove that Anglicans have always treated episcopacy as of the esse of the church. Others have endeavoured to prove that Anglicans have always fraternized with protestants, episcopal or not. It has been my endeavour to show both sides of the question. I do not profess to be impartial. I am convinced that to tamper with episcopacy would be to throw away all that is most distinctive in the character and prospects of the church of England. But I have desired to show fairly how matters have stood, and to bring out not only the earnestness with which our writers have contended for the apostolic and divine institution of episcopacy, but also their wish to make out the best possible case for those who had a different polity, while aiming in the main at promoting a scriptural and spiritual Christianity.

I have not tried to make my catena complete or exhaustive. I might have quoted from other divines besides those here mentioned-especially seventeenth century divines. But to have gone to more recondite sources, to have ransacked the 
pamphlet literature of a couple of hundred years, to have given every passage bearing upon the subject, would have swollen a book already perhaps too long without enhancing its value. I believe that the passages here given represent accurately and with sufficient fulness the mind of the English church from age to age, as seen both in its great scholars, its philosophical divines, its statesmen, and also in specimens of its average pastors, preachers, and teachers. The impression left is complex; but I think that no one who follows the evidence can doubt that the church of England stands for episcopacy with a resolution peculiarly its own.
A. J. M.

Canterbury,

St Peter's Day, r914. 


\section{CONTENTS}

CHAP.

PAGE

I. The Appeal to Antiguity . . . . . . . I

II. Episcopacy and the Elizabethans . • . $\quad 23$

III. Under James I AND Charles I * * . $\quad . \quad 65$

IV. The Restoration Period . . . . . . . $\quad$ i67

V. The Revolution and" Since . . . . . . . 277

VI. Modern Anglican Criticism . $\quad . \quad$. $\quad . \quad$. 449

Appendix A. Has the Reformed Church of England eVer Admitted into her Ministry Men NOT EPIscopally ORdained? • . . $\quad 489$

B. The Foreign Reformed Churches and the Plea of Necessity . . . . . . 512

C. Ordination among the Nonconformists OF ENGLAND $\quad . \quad \cdot \quad \cdot \quad \cdot \quad \cdot \quad \cdot \quad 528$

D. Schism and Communion $\quad$ - $\quad . \quad$. $\quad 534$

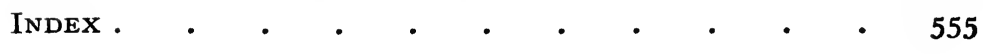




\section{ADDENDUM}

I ought to have mentioned on p. 475 an early testimony to the exceptional powers ascribed to the Alexandrian presbyters which seems to have been unknown to Lightfoot.

"Certain heretics came one day to Poemen, and began to run down the Archbishop of Alexandria, saying that he received his ordination from presbyters. The old man said nothing, but called his brother and said, 'Set the table, and make them eat, and send them away with peace." "

The story is found in a collection of Apophthegms of the Fathers printed in Migne's Patrologia Graeca Lxv. Abbot Butler, to whose Lausiac History of Palladius (vol. I. p. 213) I owe my knowledge of the story, thinks that the apophthegm "can hardly have originated out of Egypt or after the fourth century." Poemen is generally supposed to have died about 460 ; but as Rufinus visited him in his monastery about 375 (Butler, ut supra, p. 223), this date is too late.

A. J. M. 


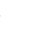




\section{CHAPTER I}

THE APPEAL TO ANTIQUITY

BEFORE a complete answer can be given to the question how the reformed church of England regards episcopacy, it is necessary to remember that the reformed church of England has always refused to be considered as an offspring of the age of the Reformation. It does not start with a constitution drawn up for the first time in the sixteenth or seventeenth century. It claims continuity with the church of apostolic times. It inherits the vast store of earlier traditions, except where it has expressly or tacitly repudiated any part of the store. Whatever can be shown to be the teaching of scripture and of the unanimous voice of the early church is for that very reason the teaching of the church of England, even if it has not been explicitly accepted and professed. If in any point her formularies themselves should be found to contradict what is shown by a sounder exegesis to be the meaning of scripture,if a more thorough knowledge of history should prove that her divines misunderstood the practice or doctrine of the fathers,- the representatives of the 
church of England today would not stand committed to the mistake. The appeal to antiquity has already been provided for them in advance. The wise and learned men who shaped the system under which we live, consistently maintained that they were devising nothing new, but returning to the old,-and to the old, not as contained only in the New Testament, but as exhibited in the early undivided church. They did not treat the New Testament, as some of the continental reformers and of their scholars in this island treated it, or as many critics of the present day treat it, as if it had come into their hands from an unknown world, to be deciphered for the first time, regardless of the church life out of which it sprang. Their one desire was to be faithful to the scripture; but for that very reason they used for its interpretation, though not without criticism, the commentary supplied by the fathers, and by the histories and by the enactments of primitive Christianity.

This is the meaning of that magnificent appeal which Cranmer made at the time of his degradation, on behalf of others as well as for himself.

First, my plain protestation made, that I intend to speak nothing against one holy catholic and apostolical church, or the authority thereof, (the which authority I have in great reverence, and to whom my mind is in all things to obey)...I do challenge and appeal from the pope... as well for myself as for all and every one that cleaveth to me or will hereafter be on my side, unto a free general council.... And touching my doctrine of the sacrament, and other my doctrine, of what kind soever it be, I protest that it was 


\section{The Appeal to Antiquity}

never my mind to write, speak, or understand anything contrary to the most holy word of God, or else against the holy catholic church of Christ ; but purely and simply to imitate and teach those things only, which I had learned of the sacred scripture, and of the holy catholic church of Christ from the beginning, and also according to the exposition of the most holy and learned fathers and martyrs of the church. And if anything hath peradventure chanced otherwise than I thought, I may err, but heretic I cannot be, forasmuch as I am ready to follow the judgment of the most sacred word of God and of the holy catholic church, desiring none other thing than meekly and gently to be taught, if anywhere (which God forbid) I have swerved from the truth $\mathbf{1}$.

Beneath the broad aegis which Cranmer threw over us who in subsequent ages have been on his side, the church of England has developed freely, making always the same appeal to the unalterable testimony of antiquity. It may seem strange, perhaps, that Cranmer himself, and that some of his followers, whose doctrine on many points has a revolutionary appearance, could make this appeal. Yet it was sincerely made and meant. Those who represent the main stream of Anglican tradition, however protestant their language may at times have been, have believed that they were acting and teaching in the spirit, not only of the apostles, but also of the fathers, and carrying on unchanged the life of the church of the first six centuries.

Jewel's famous challenge, in I559, sounded the same note which Cranmer had uttered.

1 The Remains of T. Cranmer (ed. Jenkins), vol. IV. pp. I2I, I26. 
The words that I then spake, as near as I can call them to mind, were these : If any learned man of all our adversaries, or if all the learned men that be alive, be able to bring any one sufficient sentence out of any old catholic doctor or father, or out of any old general council, or out of the holy scriptures of God, or any one example of the primitive church, whereby it may be clearly and plainly proved that there was any private mass in the whole world at that time, for the space of six hundred years after Christ ; or [various other things]; I promised then that I would give over and subscribe unto him ${ }^{1}$.

What Jewel in his sermons threw into the form of a challenge, he repeated deliberately, again and again, in his Apologia Ecclesiae Anglicanae, which was translated into English by Bacon's mother and the translation published in 1564 , with a letter of commendation from Archbishop Parker, and became at once the standard exposition of the teaching of the English church.

They cry out upon us at this present everywhere, Jewel says in the Apology, that we are all heretics, and have forsaken the faith, and have with new persuasions and wicked learning utterly dissolved the concord of the church ;...that we have seditiously fallen from the catholic church, and by a wicked schism and division have shaken the whole world, and troubled the common peace and universal quiet of the church;...that we set nought by the authority of the ancient fathers and councils of old time; that we have rashly and presumptuously disannulled the old ceremonies,

1 Works (Parker Society), part I, p. 20. The sermon from which these words are taken was preached at Paul's Cross in Lent, I559 (I560), when Jewel had been consecrated bishop. The earlier challenge, to which he refers, had been delivered on Nov. 26 of the previous year, before his consecration. 


\section{The Appeal to Antiquity}

which have been well allowed by our fathers and forefathers many hundred year past both by good customs and also in ages of more purity ; and that we have by our own private head, without the authority of any sacred and general council, brought new traditions into the church, and have done all these things not for religion's sake, but only upon a desire of contention and strife: but that they for their part have changed no manner of thing, but have held and kept still such a number of years to this very day all things as they were delivered from the apostles and well approved by the most ancient fathers ${ }^{1}$.

In the Defence of the Apology (I567), Jewel describes the relation of the church of England to its own past and to the Roman communion of his own time :

This one thing are they never able truly to say, that we have swerved either from the word of God, or from the apostles of Christ, or from the primitive church. Surely we have ever judged the primitive church of Christ's time, of the apostles, and of the holy fathers, to be the catholic church: neither make we doubt to name it Noe's ark, Christ's spouse, the pillar and upholder of all truth, nor yet to fix therein the whole mean of our salvation. It is doubtless an odious matter for one to leave the fellowship whereunto he hath been accustomed, and specially of those men who, though they be not, yet at least seem and be called Christians. And to say truly, we do not despise the church of these men (however it be ordered by them now-a-days) partly for the name sake itself, and partly for that the gospel of Jesu Christ hath once been therein truly and purely set forth, neither had we departed therefrom but of very necessity and much against our wills.... As touching that we have now done, to depart from that church, whose errors were proved and made manifest to the world,... and yet

'Works, part III, pp. 53 foll. 
not to depart so much from itself as from the errors thereof, ... we have done nothing herein against the doctrine either of Christ or of his apostles ${ }^{1}$.

To conclude, we have forsaken the church as it is now, not as it was in old time ;... and to say truth, we have been cast out by these men (being cursed of them, as they use to say, with book, bell, and candle), rather than have gone away from them of ourselves ${ }^{2}$.

Though we have departed from that church, which these men call catholic,...yet is this enough for us,...that we have gone from that church which had the power to err; which Christ, who cannot err, told so long before it should err; and which we ourselves did evidently see with our eyes to have gone both from the holy fathers, and from the apostles, and from Christ his own self, and from the primitive and catholic church; and we are come, as near as we possibly could, to the church of the apostles and of the old catholic bishops and fathers, which church we know hath hitherunto been sound and perfect, and, as Tertullian termeth it, a pure virgin, spotted as yet with no idolatry, nor with any foul or shameful fault ${ }^{3}$.

When asked what he thought of his own predecessors in the see of Salisbury, Jewel's reply was:

For the rest of the bishops [of Salisbury] that were before them [i.e. before Shaxton and Capon], what faith they held, and what they either liked or misliked, by their writings or sermons it doth not greatly appear. I trust they held the foundation, and lived and died in the faith of Christ. If they had lived in these days, and seen that you see, they would not have been partakers of your wilfulness... To be short, we succeed the bishops that have been before our days. We are elected, consecrate, confirmed,

1 Works, part III, pp. 77, 79.

2 Ibid. p. 92.

3 Ibid. p. 100. 


\section{The Appeal to Antiquity}

and admitted, as they were. If they were deceived in anything, we succeed them in place, but not in error. They were our predecessors, but not the rulers and standards of our faith ${ }^{\mathbf{1}}$.

The books of Homilies, to which reference is made in the Thirty-nine Articles have a look of uncompromising protestantism. They are controversial in their general tone, and somewhat repellent in their form of argument. Nevertheless, their intention and for the most part their method is the same as Jewel's :

They are above all valuable on account of the principle which underlies all their teaching. This principle is the appeal to holy scripture as the criterion of the faith, the appeal to the early fathers, to the mind of the " ancient and primitive church," not in any puritan sense, as binding the outward action of the Christian society in details, but as the safeguard of all true progress and development. This standard... is constantly present to the authors of the Homilies.... If... we desire to know what the church should believe, teach, or do in any controverted matter of doctrine or practice, it is the "good fathers in the primitive church," or the " ancient catholic fathers," to whom we are sent by the writers of the Homilies. And in describing the church and its three notes and marks we are told that this description " is agreeable to the scriptures of God and also to the doctrine of the ancient fathers, so that none may justly find fault therewith."...Primarily, the writers go to "the manifest doctrine of the scriptures" ; secondarily, to "the usage of the primitive church, which was most pure and uncorrupt ": and then to "the sentences and judgments of the most ancient, learned, and godly doctors of the church"; or, as it is said afterwards, to "the testimonies of the holy

1 Works, part III, p. 339. 
and ancient learned fathers and doctors, out of their own works, and ancient histories ecclesiastical ${ }^{1}$."

In the same month that Jewel repeated his challenge at Paul's Cross, the same ground was taken by another representative churchman. Horne, who was appointed to open the Westminster conference of March 1559 (I560) between the Marian divines and their rivals, prefaced his discourse with these memorable words, among others:

Forasmuch as we have for our mother the true and catholic church of Christ, which is grounded upon the doctrine of the apostles and prophets, and is of Christ the head in all things governed; we do reverence her judgment ; we obey her authority as becometh children; and we do devoutly profess, and in all points follow, the faith which is contained in the three creeds, that is to say, of the apostles, of the council of Nice, and of Athanasius....

As for the judgment of the whole controversy, we refer unto the most holy scriptures, and the catholic church of Christ, whose judgment unto us ought to be most sacred. Notwithstanding, by the catholic church we understand not the Romish church, whereunto our adversaries attribute such reverence; but that which St Augustine and other fathers affirm ought to be sought in the holy scriptures, and which is governed and led by the Spirit of Christ ${ }^{2}$.

It was at the same time that Archbishop Parker, with other bishops, put forth a "declaration" which the parochial clergy were to make before their people. In it, they stated that they believed " whatsoever is

1 The Witness of the Homilies (Church Historical Society publications, No. LxIr. 1900), pp. 20, 25, where the references to the particular passages are given. Cf. Remains of Alexander Knox, vol. III. p. 44 .

${ }^{2}$ Cardwell Conferences, p. 55. 


\section{The Appeal to Antiquity}

contained in the holy canonical scriptures," and " all the articles contained in the three creeds"; that they acknowledged " that church to be the spouse of Christ, wherein the word of God is truly taught, the sacraments orderly ministered according to Christ's institution, and the authority of the keys duly used " ; that they confessed " that it is not lawful for any man to take upon him any office or ministry but such only as are lawfully thereunto called by their high authorities, according to the ordinances of this realm "; that they acknowledged and confessed that the power challenged by the bishop of Rome "is an usurped power, contrary to the scriptures and word of God, and contrary to the example of the primitive church" ; and that they granted and confessed that the book of common prayer "is agreeable to the scriptures, and that it is catholic, apostolic, and most for the advancing of God's glory ${ }^{1}$."

The Canons of I57I, though subscribed by the bishops of both provinces, were never ratified by royal authority, and therefore never took legal effect. Nevertheless they indicate plainly the views of the church of England at the time, and have therefore a historical value quite independent of canonical validity. The canon relating to Concionatores says :

Inprimis vero videbunt, ne quid unquam doceant pro concione, quod a populo religiose teneri et credi velint, nisi quod consentaneum sit doctrinae veteris aut novi testamenti, quodque ex illa ipsa doctrina catholici patres et veteres episcopi collegerint ${ }^{2}$.

1 Cardwell Conferences, pp. 263 foll.

2 Cardwell Synodalia, vol. I. p. I26. 
Unquestionably the main object of this canon was to keep out what it calls " aniles opiniones et haereses, et errores pontificios," though incidentally it glances also at the vice of " novitatis studium." It is the spirit of Jewel which still breathes in it, and the same spirit breathed in the rules laid down by the Privy Council in 1582 for the guidance of the bishops :

If the papists shall show any ground of scripture, and wrest it to their sense, let it be showed by the interpretation of the old doctors, such as were before Gregory I. But if they can show no doctor that agreed with them in their said opinion before that time, then to conclude that they have no succession in that doctrine from the time of the apostles and above four hundred years after (when doctrine and religion were most pure), for that they can show no predecessor whom they might succeed in the same.

But obviously the mind which condemned Rome for innovations upon primitive catholicism was likely to condemn innovations in other quarters for the same reason. A mightier than Jewel showed that Jewel's sword had two edges. Hooker, whose early career had been fostered by Jewel, grew up with a greater attachment to the Anglican principle than Jewel had ever had. He saw the principle assailed not only by Rome, but still more formidably, for the moment, from the opposite quarter. Puritanism demanded a clean sweep of everything that bore a resemblance to the practice and worship of the church in the days before the reformation, and insisted that nothing should be permitted which had 


\section{The Appeal to Antiquity}

not the express sanction of scripture. In the department of ecclesiastical polity it erected a system which professed to be wholly derived from scripture, but was in fact based upon an imaginary exegesis, controlled by no historical considerations. Its career, in the reign of Elizabeth, was so triumphant that Hooker felt it not improbable that the state of things which Cranmer and Parker had established might "pass away as in a dream ${ }^{1}$."

Against this system Hooker's whole work is directed. Only a few sample passages need be quoted here.

Whereas St Augustine affirmeth that those things which the whole church of Christ doth hold may well be thought to be apostolical, although they be not found written; this his judgment they utterly condemn. I will not here stand in defence of St Augustine's opinion,... but... they who condemn him herein must needs confess it a very uncertain thing what the orders of the church were in the apostles' time, seeing the scriptures do not mention them all, and other records thereof besides they utterly reject ${ }^{2}$.

Let the church of Rome be what it will, let them that are of it be the people of God and our fathers in the Christian faith, or let them be otherwise; hold them for catholics or hold them for heretics; it is not a thing either one way or other in this present question greatly material. Our conformity with them in such things as have been proposed is not proved as yet unlawful by all this. St Augustine hath said, yea and we have allowed his saying, " that the custom of the people of God and the decrees of our forefathers are to be kept, touching those things whereof the scripture hath neither one way nor other given us any charge ${ }^{3} . "$

${ }^{1}$ Eccl. Pol. Preface, I. I. $\quad{ }^{2}$ Book IV. II. 2. $\quad{ }^{3}$ Book IV. V. I. 
We... are now, they say,... more bound to differ from them [the church of Rome] in ceremonies than from Turks. A strange kind of speech unto Christian ears, and such as I hope they themselves do acknowledge unadvisedly uttered... . Even a very part of them we were. And when God did by his good Spirit put it into our hearts, first to reform ourselves (whence grew our separation), and then by all good means to seek also their reformation; had we not only cut off their corruptions, but also estranged ourselves from them in things indifferent, who seeth not how greatly prejudicial this might have been to so good a cause, and what occasion it had given them to think (to their greater obduration in evil) that through a forward or wanton desire of innovation we did unconstrainedly those things for which conscience was pretended ${ }^{1}$ ?

The ceremonies which we have taken from such as were before us are not things that belong to this or that sect, but they are the ancient rites and customs of the church of Christ, whereof ourselves being a part, we have the selfsame interest in them which our fathers before us had, from whom the same descended unto us ${ }^{2}$.

Was it amiss that [our reformers]... went not on till they had plucked up...those things which to abrogate, without constraint of manifest harm thereby arising, had been to alter unnecessarily (in their judgment) the ancient received custom of the whole church, the universal practice of the people of God, and those very decrees of our fathers which were not only set down by agreement of general councils, but had accordingly been put in use and so continued in use till that very time present ?... What exception can there be taken against the judgment of St Augustine, who saith, "That of things harmless, whatsoever there is which the whole church doth observe throughout the world, to argue for any man's immunity from observing the same,

1 Book IV. vir. 6.

${ }^{2}$ Book IV. IX. I. Compare the noble passage in the following section. 


\section{The Appeal to Antiquity}

it were a point of most insolent madness ?" And surely odious it must needs have been for one Christian church to abolish that which all had received and held for the space of many ages ${ }^{1}$.

One more quotation from Hooker must be given. It is probably the best-known of all ; it reveals at once his sense of close community with other reformed churches, and the independence conferred by a historic connexion with the past.

To say that in nothing they may be followed which are of the church of Rome were violent and extreme. Some things they do in that they are men, in that they are wise men and Christian men some things, some things in that they are men misled and blinded with error. As far as they follow reason and truth, we fear not to tread the selfsame steps wherein they have gone, and to be their followers. Where Rome keepeth that which is ancienter and better, others whom we much more affect leaving it for newer and changing it for worse, we had rather follow the perfections of them whom we like not, than in defects resemble them whom we love ${ }^{2}$.

The contemporary and friend of Hooker, Richard Field, in his great book Of the Church, shows everywhere the same opinion. Thus for example he speaks of

those different degrees of obedience, which we must yield to them that command and teach us in the church of God, excellently described and set down by Waldensis ${ }^{3}$. "We must," saith he, "reverence and respect the authority of all catholic doctors whose doctrine and writings the church alloweth: we must more regard the authority of catholic

1 Book IV. xiv. 4, 6.

2 Book V. Xxviri. I.

3 Thomas Netter of Walden, the great opponent of the Wicliffites. 
bishops: more than these, the authority of the Apostolic Churches; amongst them, more specially the church of Rome: of a general council, more than all these: yet we must not listen so to the determinations of these, nor so certainly assent unto them, as to the things contained in the scripture, or believed by the whole universal church that hath been ever since the apostles' time, but as to the instructions of our elders, and fatherly admonitions. We must," saith he, "obey... unless they teach us anything which the authority of the higher and superior controlleth : yet so, as then, the humble and obedient children of the church must not insolently insult upon them from whom they are forced to dissent, but must dissent with a reverent, childlike, and respectful shamefacedness ${ }^{1} . "$

Of the authority of scripture, which he maintains as supreme, Field yet writes :

The apostles wrote to them that they had formerly taught more at large; neither can the scriptures be understood now, but only by such as will be taught by the successors of the apostles and guides of the church, though, being so taught, they may assuredly find by the scriptures themselves that they do understand them aright ${ }^{2}$.

To the Romanist who made use of Field's assertion that the supreme authority of interpretation lies in a general council of Christendom, to show from it that such a general council was impossible except for the Roman church, Field replies, with a recognition of the Eastern churches which was not uncommon among the Elizabethan divines:

The greatest parts of the Christian world have remained divided from the Roman church for the space of six or seven hundred years. If the author of these proofs shall

1 Vol. II. p. 404 (E.H.S. ed.).

${ }^{2}$ Vol. IV. p. 444, n. I. 
say, they have all been heretics and schismatics, and that they have lived and died in state of damnation that have lived and died in those churches ever since their separation, and that therefore a general council of the Christians of the West adhering to the pope is absolutely general and œcumenical, representing the whole universal church, we detest so unchristian and devilish a censure : and therefore we willingly confess that the protestants, being but a part of the Christian church, cannot have any council absolutely general, but in a sort only in respect of those of their own profession. Such a general council of protestants to settle and compare their differences [a protestant author] wisheth for, neither doth he ever deny the possibility thereof,... but saith only that, as things now stand, there being no better correspondence among Christian princes, nor greater desire of making up the breaches of the Christian church, there is little hope of any such general meeting of those of the reformed religion ${ }^{1}$.

Field denies that the Roman church of his time was the same as the Roman church before Luther's time :

The errors that we condemn were taught in the Roman church that was when Luther began, but they were not the doctrines of that church ; but these errors are of the doctrines of the present Roman church.... We must observe that the doctrines in that [ancient Roman] church were of three sorts. The first, such as were delivered with so full consent of all that lived in the same, that whosoever offered to teach otherwise was rejected as a damnable heretic; such was the doctrine of the Trinity.... The second, such errors as were taught by many in the midst of the same church, as that the pope cannot err, and the like. The third, such contrary true assertions as were by others opposed against 
those errors. The first were absolutely the doctrines of that church. The third may be said to have been the doctrines of the church, though all received them not.... The second kind of doctrines were not at all the doctrines of the church, because they neither were taught with full consent of all that lived in it, nor by them that were so in the church and house of God that they were the church and house of God ${ }^{1}$, but by such as... were but a faction in it.

Hence it followeth...that howsoever we have forsaken the communion of the Roman diocese, yet we have not departed from the Roman church in the later sense before expressed, wherein our fathers lived and died, but only from the faction that was in it. First, because we have brought in no doctrine then generally and constantly condemned, nor rejected anything then generally and constantly consented on. Secondly, because we have done nothing ...but removed abuses then disliked, and shaken off the yoke of tyranny which that church in her best parts did ever desire to be freed from.... Thus then (I hope) it doth appear that, howsoever I confess that the Latin or West churches, oppressed with Romish tyranny, continued the true churches of God, held a saving profession of heavenly truth, turned many to God, and had many saints that died in their communion, even till the time that Luther began; yet I neither dissent from Luther, Calvin, Beza, or any other protestant of judgment, nor any way acknowledge the present Romish church to be that true church of God whose communion we must embrace, whose directions we must follow, and in whose judgment we must rest ${ }^{2}$.

It is perhaps unnecessary to labour the point any further. The Canons of I603, citing the Apology of Jewel, set a kind of seal to this view, when they say:

1 Augustine de Bapt. vir. 5 I.

Vol. IV. pp. 525 foll. 


\section{The Appeal to Antiquity}

The abuse of a thing doth not take away the lawful use of it. Nay, so far was it from the purpose of the church of England to forsake and reject the churches of Italy, France, Spain, Germany, or any such like churches, in all things which they held and practised, that, as the Apology of the church of England confesseth, it doth with reverence retain those ceremonies which do neither endanger the church of God, nor offend the minds of sober men, and only departed from them in those particular points wherein they were fallen from themselves in their ancient integrity, and from the apostolical churches which were their first founders ${ }^{1}$.

It will not be disputed that the church of England became increasingly conscious, from the time of Hooker and Field onwards, of holding a position of its own, not identical with that of any other church in Christendom. The peculiarity consisted first and foremost in the intention to be governed by catholic principles, of which loyalty to scripture is the first, and deference to the practice of the church of the fathers is the second, while the God-given faculties of reason and criticism are freely brought to bear upon them both. There have been many good men in the church of England whose place in it might be called accidental. Their sympathies have been rather with other systems than with hers, though they have been content for various reasons to abide in her communion. It would have been a grievous loss to her if they had without necessity been constrained to abandon her. But the distinguishing character of the church of England has not been in their contribution to her fulness. It has lain in the 
confident sense of historical identity with the church of the early centuries, and not of historical identity only, but also of religious continuity and oneness of witness.

The attacks of Romanists on the one side and of Puritans on the other developed the sense of being entrusted with this special message to the world. The persecutions of Mary's reign followed by those of the Commonwealth period were permitted by the providence of God to have the effect of marking the church of England out as a thing different from Rome, in being reformed, and different from Presbyterianism or the Independents, in being catholic. Yet no persecutions could extinguish in her the feeling of kinship with both sides. Holding this central position, she has been able to provide a home for men of very varying convictions, who have felt that she possessed the secret of liberty, of progressiveness, of comprehension, along with order, authority, reverence, mystery. It was this which drew to her men like Saravia, Grotius, Casaubon, Vossius and Grabe from abroad, who found in her communion a peace which the churches of their native countries could not offer. It was this which attracted Comenius to stretch across Germany, Holland, Switzerland and France, to commit his Unitas Fratrum to the good offices of the church of England.

Two extracts, and only two out of many, are here added as examples of the way in which the great Anglicans of the seventeenth century understood the principle laid down by their predecessors in the sixteenth. 


\section{The Appeal to Antiquity}

The first is the famous preface to Bramhall's Replication to the Bishop of Chalcedon:

No man can justly blame me for honouring my spiritual mother, the church of England, in whose womb I was conceived, at whose breasts I was nourished, and in whose bosom I hope to die. Bees by the instinct of nature do love their hives and birds their nests. But God is my witness... my desire hath been to have truth for my chiefest friend, and no enemy but error. If I have had any bias, it hath been desire for peace, which our common Saviour left as a legacy to his church; that I might live to see the reunion of Christendom, for which I shall always bow the "knees of my heart " to the Father of our Lord Jesus Christ. It is not impossible but that this desire of unity may have produced some unwilling error of love, but certainly. I am most free from the wilful love of error. In questions of an inferior nature Christ regards a charitable intention much more than a right opinion.

Howsoever it be, I submit myself and my poor endeavours, first, to the judgment of the catholic ecumenical essential church; which if some of late days have endeavoured to hiss out of the schools as a fancy, I can not help it. From the beginning it was not so. And if I should mistake the right catholic church out of human frailty or ignorance (which for my part I have no reason in the world to suspect...), I do implicitly and in the preparation of my mind submit myself to the true catholic church, the spouse of Christ, the mother of the saints, the pillar of truth. And seeing my adherence is firmer to the infallible rule of faith, that is the holy scriptures interpreted by the catholic church, than to mine own private judgment or opinions; although I should unwittingly fall into an error, yet this cordial submission is an implicit retractation thereof, and I am confident will be so accepted by the Father of mercies, both from me and all others who seriously and sincerely do seek after peace and truth. 
Likewise I submit myself to the representative church, that is, a free general council, or so general as can be procured; and until then, to the church of England, wherein I was baptized, or to a national English synod; to the determination of all which, and each of them respectively, according to the distinct degrees of their authority, I yield a conformity and compliance, or at the least, and to the lowest of them, an acquiescence ${ }^{1}$.

The second is from Bull's Apology for his Harmonia Apostolica. A certain Dr Tully had attacked that book for teaching "innovations" upon the doctrine-the Calvinistic doctrine-which he imagined the English church to have received and approved. In the midst of a noble passage, in which he vindicates the freedom of the English church from the decisions of the synod of Dort and other modern dogmas, Bull says :

Every one who is not a mere novice in the history of our church must know that our reformation was in all respects conformed to the example of the ancient church catholic, that is, so far as it was possible, and the age would allow. Hence the order of bishops was retained in England, that new form of ecclesiastical government being rejected which by the advice of Calvin had been established in neighbouring churches. Hence forms of public prayer, rites, and ceremonies, all of them most ancient, have been religiously observed amongst us. Hence certain ancient doctrines, although greatly at variance with Calvin's tenets ...have been fixed and established amongst us: so that even from the original constitution of our reformed church her sons may learn how much deference they ought to pay to the judgment of the ancient catholic church. Hence too that canon concerning preachers... almost in the earliest

1 Works, vol. II. p. 2 I. 


\section{The Appeal to Antiquity}

times of our reformation, namely in the year $\mathbf{5 7}$, was sanctioned by the consent of a full provincial synod,... "And above all, they shall take care that they preach nothing ... except that which is agreeable to the doctrine of the Old and New Testament and which the catholic fathers and ancient bishops have collected from that very doctrine." Hence amongst the rules and directions which, by the advice of the bishops, the wise King James... recommended to...the university of Oxford,...the following direction was inscribed: it is the seventh in order; "that young students in divinity be directed to study such books as be most agreeable in doctrine and discipline to the church of England, and excited to bestow their times in the fathers, councils, schoolmen, histories, and controversies and not to insist too long upon compendiums and abbreviatures, making them the grounds of their study in divinity...." Hence the most eminent theologians of our church have constantly and openly declared that they entirely embraced the consent of the ancient fathers, and that they would never admit anything, either in doctrine or ecclesiastical government, which was contrary to it.

After quoting as examples " the learned Saravia," " the great Jewel," " the learned Bilson," " the great Casaubon," "the learned Montague," " his most reverend successor in the see of Norwich, Joseph Hall," " our great Hammond," Bull concludes :

Here then I take my stand...God knows the secrets of my heart. I am so averse to any itching desire for innovation in theological doctrines... that whatever has been approved of by the consent of catholic fathers and ancient bishops, even though my poor intellect cannot see it, yet I embrace with all reverence. In truth, when as a young man I was writing the Harmony, I learned from no small experience, which now in more matured age I am most persuaded of, that no one can oppose catholic consent without 
his being in the end found to have opposed both the divine oracles and sound reason, however much some passages in holy writ, imperfectly understood, may seem for a time to favour his cause ${ }^{1}$.

1 Bull on Justification (1843), part III, pp. 23I-235. An interesting catena of passages from Anglican writers to the same effect is given in the Tracts for the Times, No. LxxvirI., which is reprinted at the end of Keble's sermon on Primitive Tradition. The catena has been criticised by W. Goode in his Divine Rule of Faith and Practice. Goode's criticisms would be valid against any who used these authorities as if they favoured the view that tradition is a coordinate source of Christian doctrine; but the passages quoted exemplify the true $\eta^{3} \theta$ os of Anglican theology from Jewel to Van Mildert. 


\section{CHAPTER II}

\section{EPISCOPACY AND THE ELIZABETHANS}

Among the catholic principles which have been dear to the church of England, none has been dearer to her than the principle of episcopacy. However charitably her divines have felt and spoken of those who had no episcopate, it would be absurd to maintain that she has looked upon the question of ecclesiastical polity as one of indifference, or even of minor importance. No other church in Christendom has devoted so much thought and learning to the subject, or vindicated so successfully the apostolic origin and sanctions of the episcopate. The great representative Anglican divines have felt that her claim to catholicity was inseparably bound up with the rightful succession of her bishops.

Perhaps one reason, conscious or unconscious, for the special veneration in which that order has been held in the reformed church of England was that so many men belonging to the order gave life and everything else for the cause of the reformation. No fewer than five English bishops were burned alive under Mary,- " a glorious crown of bishops," says the historian Dixon, " the like of which is set upon the 
brow of no other church in Christendom ${ }^{1}$." Spain had one confessor-archbishop in the same period, the Rhine-land had another, but the bishops in other countries for the most part took a widely different line.

It will hardly be disputed that it was the hand of Cranmer which drew up the Preface to the Ordinal of 1552 , which with but slight modification has remained a law to the church of England ever since:

It is evident unto all men, diligently reading holy scripture, and ancient authors, that from the aposties' time there hath been these orders of Ministers in Christ's church; Bishops, Priests, and Deacons: which offices were evermore had in such reverent estimation, that no man, by his own private authority, might presume to execute any of them, except he were first called, tried, examined, and known to have such qualities as were requisite for the same; and also, by public prayer, with imposition of hands, approved and admitted thereunto. And thereto, to the intent these orders should be continued, and reverently used and esteemed in this church of England, it is requisite that no man (not being at this present Bishop, Priest, nor Deacon) shall execute any of them, except he be called, tried, examined, and admitted according to the form hereafter following 2 .

1 History of the Church of England, vol. Iv. p. 552.

- 2 Cardwell The two Books of Common Prayer, p. 398. Cranmer's views were set forth in his translation of the catechism of Justus Jonas in 1548 : "The apostles laid their hands upon [others] and gave them the Holy Ghost, as they themselves received of Christ the same Holy Ghost to execute this office... And so the ministration of God's word (which our Lord Jesus Christ himself did first institute) was derived from the apostles unto others after them by imposition of hands and giving the Holy Ghost from the apostles' time to our days. And this shall continue in the church even to the world's 
How seriously the principle here laid down was taken is shown by the consecration of Archbishop Parker after the accession of Elizabeth. There is no need to repeat here the story of that much discussed event, but the particularity with which the archbishop himself records every detail of it testifies to the solemn importance which it had for him.

The Apology of the Church of England lays it down, among the truths professed by us, which show that we have not departed from the ancient faith, that

We believe that there is one church of God, and that the same is not shut up (as in times past among the Jews) into some one corner or kingdom, but that it is catholic and universal and dispersed throughout the whole world;... and that this church is the kingdom, the body, and the spouse of Christ ; and that Christ alone is the prince of this kingdom ; that Christ alone is the head of this body; and that Christ alone is the bridegroom of this spouse. Furthermore that there be divers degrees of ministers in the church; whereof some be deacons, some priests, some bishops; to whom is committed the office to instruct the people, and the whole charge and setting forth of religion.... Further, we say that the minister ought lawfully, duly, and orderly to be preferred to that office of the church of God, and that no man hath power to wrest himself into the holy ministry at his own pleasure and list. Wherefore these persons do us the greater wrong, which have nothing so common in their mouth, as that we do nothing orderly and comely,... and that we allow every man to be a priest, to be a teacher, and to be an interpreter of the scriptures ${ }^{1}$.

end" (p. I96; ed. Oxford, I829). On Cranmer's earlier utterance on the subject see E. C. Harington The Reformers of the Anglican Church and Mr Macaulay's History of England, ed. 2, 1850.

1 Jewel Works (Parker Society), part III, pp. 59, 60. 
This, to Jewel, is an integral part of the faith ; and he, like Parker, is jealous for the canonical regularity with which our bishops are appointed. $\mathrm{He}$ asserts in the Defence of the Apology:

We deny not the consecration of three bishops. We deny not the confirmation of the metropolitan. We ourselves are so consecrated, and so confirmed.... Our bishops are made in form and order, as they have been ever, by free election of the chapter, by consecration of the archbishop and other three bishops, and by the admission of the prince ${ }^{1}$.

It fell to John Whitgift to be the first author to maintain against the rising party of the presbyterians the assertion of the preface to our ordinal. This he did in his Answere to the Admonition to Parliament (1572), and in his Defense of the Answere (I574).

It is the general consent of all the learned fathers, that it pertaineth to the office of a bishop to order and elect ministers of the word. In this, saith Hierome in Epist. ad Evagrium, "a bishop doth excel all other ministers, in that the ordering and appointing of ministers doth properly pertain unto him." And yet these men say " that the right of ordering ministers doth at no hand appertain to a bishop." But for the order and manner of making ministers, peruse the book made for that purpose; and as I said before so I say again, if thou hast any judgment, thou canst not but like it and allow of it ${ }^{2}$.

Cartwright taunted him with trying to show off his patristic learning. He retorts :

Show me one father that denieth that which I here affirm :

1 Works (Parker Society), III, pp. 330, 334.

2 Ibid. I, p. 437. 


\section{Episcopacy and the Elizabethans}

if you neither do, nor can, then may my " skill in the fathers and reading" also be as much (for any thing here to the contrary) as you think I would have it seem to be ${ }^{1}$.

The authority of foreign divines was nothing to Whitgift in comparison with the plain teaching of the bible :

I know M. Calvin's interpretation upon that place ${ }^{2}$, and likewise what Musculus saith of the same...; but the words of the text be plain ${ }^{3}$.

I reverence $M$. Calvin as a singular man, and worthy instrument in Christ's church; but I am not so wholly addicted unto him, that I will contemn other men's judgments that in divers points agree not fully with him,... when as, in my opinion, they come nearer to the true meaning and sense...than he doth ${ }^{4}$.

The judgment of antiquity is of paramount value in his eyes:

There is no man of learning and modesty, which will without manifest proof condemn any order, especially touching the government of the church, that was used and allowed during the time of the primitive church, which was the next five hundred years after Christ ; within the which time most of my authorities are contained. Neither was there any function or office brought into the church during all that time, allowed by any general council or credible writer, which was not most meet for that time, and allowable by the word of God $^{5}$.

Whitgift does not hesitate to imply that it was a heretical thing to maintain that presbyters might ordain :

1 Works (Parker Society), I, p. 439.

3 Works (Parker Society), I, p. 435.

2 Tit. i. 5 .

s Ibid. II, p. 182

4 Ibid. p. 436. 
And, because all men may understand what Epiphanius' words and reasons be (which indeed pinch you very near, for he calleth you heretics), I will declare them as I have there found them. First he setteth down the heresy of Aerius in these words: "His talk was more outrageous than becomed a man; and he said, 'What is a bishop to a priest? he nothing differeth from him; for there is but one order, and the same honour and dignity. The bishop layeth on his hands ; and so doth the priest : the bishop ministereth baptism; and so doth the priest: the bishop saith divine service; and so doth the priest: the bishop sitteth in his throne; and so doth the priest.' In this he hath deceived many ; and they use him for their captain." Then doth he a little after confute this heresy with Aerius' reasons on this sort: "To say that a bishop and a priest is equal, how can it be possible? for the order of bishops is the begetter of fathers, for it ingendereth fathers to the church: the order of priests, not being able to beget fathers, doth beget sons to the church, by the sacrament of baptism, but not fathers or teachers ; and how is it possible for him to ordain a priest, not having imposition of hands to elect, or to say that he is equal with a bishop? "... Thus mayest thou see, good reader, that it is not for nought that T. C. so storms against Epiphanius, and unreverently useth him. But I will give him as much cause to deal in like manner with Augustine, who ... attributeth this also as heresy to the said Aerius ${ }^{1}$.

$\mathrm{He}$ is conscious that in this matter of the authority of bishops he is more catholic than Rome is :

This authority, which the bishops and archbishops now exercise, came first from the apostolical church, then from the example of the primitive church for the space of five hundred years after the apostles' time ; thirdly from the councils of Nice, Antioch, Constantinople, and all the best and purest councils that ever were; and last of all from the authority

1 Works, II, pp. 290 foll. 


\section{Episcopacy and the Elizabethans}

of the prince, and by the consent of this whole church and realm of England, and therefore not from the pope, who hath rather diminished it (by taking all to himself) than in any respect increased it ${ }^{1}$.

These views Whitgift consistently maintained. When Beza published a somewhat tart reply to the works of Saravia and Sutcliffe soon to be mentioned, Whitgift, by that time archbishop, wrote him a letter of remonstrance, in which, after pointing out the friendliness with which the reformed church of England had always regarded the foreign protestants, he expressed himself thus :

We make no doubt but that the episcopal degree which we bear is an institution apostolical and divine, and so always hath been held by a continued course of times from the apostles to this very age of ours.... You may remember, learned Sir, the beginnings of that episcopacy, which you make to be only of human institution, is referred by the fathers with one mouth to the apostles as the authors thereof, and that the bishops were appointed as successors to the apostles, especially in certain points of their functions; and what Aaron was to his sons and to the Levites, this the bishops were to the priests and deacons, and so esteemed of the fathers to be by divine institution ${ }^{2}$.

It has been asserted by Macaulay, and too often repeated after him, even by well informed writers, that the Elizabethan divines, at any rate the earlier ones, " defended episcopacy as innocent, as useful, as what the state might lawfully establish, as what, when established by the state, was entitled to the

1 Works, II, p. 407.

2 Strype's Whitgift, vol. II. p. I70 (Oxford, I822). 
respect of every citizen," but on no higher ground ${ }^{\mathbf{1}}$. Whitgift's language already quoted, not to say Jewel's, is sufficient disproof of this assertion; but it may be supplemented by that of Matthew Hutton, who, being then Bishop of Durham, sent to Whitgift in 1589 an account of a private lecture which he gave to Burghley and Walsingham on the authority of bishops among other things. He says that he took Titus i. 5 for his text:

And albeit that it cannot be denied but that these names episcopus and presbyter in the New Testament are often used for one thing...yet it is certain that there was an office in the apostles' time, which Titus and Timothy did exercise, which was distinct from the office of them who had only authority to preach and minister the sacraments, but not to appoint priests and censure offenders... I alleged last of all that Epiphanius, writing against Aerius, concludeth it for a heresy to say Idem est episcopus et presbyter ${ }^{2}$.

When he was Archbishop of York, in I603, Hutton again sent his opinion to Whitgift in view of the approaching conference at Hampton Court :

Bishops have their authority not by any custom or decree of man, but from the apostles themselves, as Epiphanius proveth plainly against Aerius the heretic...And so it hath continued in the church ever since.

$\mathrm{He}$ argues the advantages of episcopacy as against "presbytery" from a political point of view, alleging the Aristotelian classification of good and

1 History of England, ch. I.

2 Strype's Whitgift, Book III, Appendix, No. xLIV. 


\section{Episcopacy and the Elizabethans}

evil states; but there is no doubt that he relied chiefly upon the scriptural and patristic grounds for his belief $\mathbf{1}$.

In I580, William Fulke, who succeeded (with one between) both Hutton and Whitgift in the mastership of Pembroke Hall at Cambridge, published a book against certain Romanist assailants. Fulke was a very decided protestant; but his protestantism did not teach him to adopt the views of episcopacy which Macaulay and his followers attribute to the early Elizabethans. He writes:

If the apostleship had ceased before bishops had been ordained, bishoplike power would have ceased with it; but seeing the apostles ordained bishops and elders in every congregation to continue to the world's end, the bishop's office hath not ceased, though the office of the apostles is expired ${ }^{2}$.

\section{And again :}

We doubt not, therefore, but determine with Augustine ...to rest in the bosom of that church, which from the seat of the apostles by consent of mankind hath continued by succession of bishops and hath obtained the height of authority, all heretics barking at it $^{3}$.

The first formal treatise on the orders of the ministry published in England in Elizabeth's reign was composed by a foreigner. Hadrian Saravia, a Dutchman of Spanish extraction, who had settled

1 Strype, ut supra, Book IV, Appendix, No. xLIV. For the opinion of a still earlier reformer, Gilpin, the apostle of the North, see below, p. 106.

\footnotetext{
2 Answers (Parker Society), p. 3 Iо.

${ }^{3}$ Ibid. p. 67.
} 


\section{Episcopacy and the Elizabethans}

in the Channel Islands about the year 1560 , but returned to his native country in $\mathrm{I}_{5} 82$ to be a Divinity Professor at Leyden, attached himself permanently to the English church in 1587 , and was appointed to an English benefice. In the year I590 he published his book De Diversis Gradibus Ministrorum Evangelii, of which an English translation

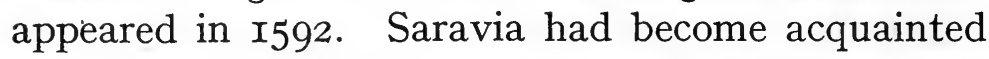
with many leading ecclesiastics in England, and states in the dedicatory letter prefixed to his collected Tractatus in I6ro that he was impelled to write on the subject by two deceased Archbishops of Canterbury, presumably Whitgift and Bancroft. The direct object of the work, however, was not so much to combat the English presbyterians, as to persuade his compatriots in the Low Countries to restore episcopacy there. An epistle addressed to the brethren whom he had left, but for whom he still entertained a warm affection, serves as an introduction to the book. The Elizabethan translator, after the manner of his kind, has succeeded in imparting to the work a raciness which is not always so apparent in the original.

Saravia apologises in his "Epistle Dedicatory" to Whitgift, Sir Christopher Hatton, and Lord Burghley, for touching at all upon English affairs :

I could not well prosecute [my argument] without some particular mention of the church of England. In the which, seeing I have now my part and portion of a pastoral province (and praised be the Lord, my lot is fallen unto me in a fair ground), might I not seem unmindful of my good and neglecting 
my duty, if when I undertake the cause of those churches which are alien and outlandish, I should overslip the state of mine own church now gremial to me and mere English ? But when mine heart's desire and prayer to God is that I may some ways benefit my countrymen, [what] if I forget thee, O Jerusalem?... But because I am but new made, of Flemish, sterling - that is, of outlandish, English, it may be haply that they which are home-bred will think I deal not well with them... and that I meddle too far, when I come so near.

He wishes that his Dutch brethren could share his lot, though they had failed him in the struggle which led to his emigration :

Neither is it enough for me that I am here well provided for myself ; I wish the like unto my brethren. And although I may justly complain myself to be injuriously forsaken of you, whom I ought to have found the chief patrons of mine innocency, yet, notwithstanding, my love and my zeal both towards the church and also unto youwards is not therefore either altered or alienated. And how then should I be less careful for yours and your churches' good than when myself was in the same ship with you ${ }^{1}$ ?

He fears that they will not like his doctrine:

But it is to be feared, lest some will be scarcely well pleased (especially such as be ignorant of the ancient church government) with this my treatise of the divers degrees of the ministers of the gospel. and the rather for that I have noted in their new-come reformation two things not to be liked of: namely, that the authentic order of bishops is abrogated, and a novel kind of presbyters intruded ${ }^{2}$.

He shows that the foreign congregations in England were used as an argument against the English church which protected them:

1 Epistle to the Ministers of the Low Countries.

2 Ibid.

M. 


\section{Episcopacy and the Elizabethans}

There are here in England a certain number of wicked men (and I am very sorry for them), who are so far out of order with that order [of bishops], as if no ecclesiastical discipline were to be had under them. Amongst whom the quarrel is grown so far, that now they divorce themselves from the communion of the English church as papistical and antichristian, and so betake themselves to their private and not permitted conventicles. Whom I could do no less than lightly note in this place, because they seem to patronage their odious schism and mutinous hugger-mugger by the precedent presidents of our foreign churches. O God, thou knowest, and themselves cannot be ignorant, that the first peregrine churches which were here in England had their Lord Bishop, Alasco, and these which at this day are under the protection of the most gracious Elizabeth do acknowledge the bishops of those dioceses in the which they are, and to them they supply. But thanks be unto God, there are others, who, being somewhat more mild and moderate in their proceedings, do not altogether estrange themselves from the assemblies of their churches; but yet they have the bishops in emulation also ${ }^{1}$.

Saravia avows at the outset his conclusion of the necessity of bishops where they can be had:

For my part (and the best will take my part) I hold that the state of bishops is necessary in the church, and that [that] discipline is best, and from above, in the which godly bishops with the not nick-named elders do sit at the helm. And yet, when I consider with myself the badness of these times, and the bad condition of some places, in the which it hath pleased God by the hands of learned and religious men to gather together his dispersed flock out of the captivity of Babylon, I do not see indeed how the true bishops could have been restored.... But shall that which was done extraordinarily, and partly of necessity, and that but in a certain

1 Epistle to the Ministers of the Low Countries. 


\section{Episcopacy and the Elizabethans}

few places, and that but in our age only, prescribe a law to the world besides ${ }^{1}$ ?

Against the constant and consonant conclusions of the ancient church we ought not to attempt or admit any innovation without a plain commission from God's holy writ : and this also I dare boldly say, that whosoever taketh away all authority from the fathers, he leaveth none for himself. Indeed it must be confessed that the fathers were men, and that they had their wrinkles: yet can it not be denied that to have our fathers to be our patrons in the principal points of faith and extern policy of our church (things controverted between the popelings and us) is a matter of no small moment and of special account. And albeit the uniform consent of God's children from the apostles' times unto this day may not be compared with the eternal word of God, notwithstanding, of right it may come in, and stand for the second place. The custom of God's people, received of all churches throughout the whole world, is in manner of a law, sacred and inviolable, neither is there any likelihood that there could ever have been an universal consort of all churches and ages without either the authority of God's word or the tradition of the apostles ${ }^{2}$.

The time hath been when no good men disallowed of bishops and archbishops ; but now... it is come to this pass, that their very names are called into question, and that of diverse men, for diverse causes. Some, because they are (as they suppose) the devices of antichrist or his forerunners, think them unworthy the church, and worthy to be cast overboard. Others, yet more modest, in some reverence of antiquity, think they may be borne withal for a time (although in the meantime they allow not of them), until such time as commodiously the names may be antiquated with the things themselves. In the meanwhile, for that they know... to what singular effect the church of God hath been governed by grave and godly bishops, they have not the face to condemn them openly : yet because they see certain reformed

1 To the Reader.

2 Ibid. 
churches of this age to be governed without bishops, it is enough-they have not the power any longer to tolerate the more ancient government ${ }^{1}$.

Are you so far in love with your lifeless Pygmalion, the work of your own hands? I know who is not; and he hath reason for his why not. For neither is your new draught of strange government sufficiently proved by the word of God, neither is it yet, or can at any time, be confirmed by the example of our elders. And how should it,... . seeing it was partly unknown unto them, and partly condemned of them as a thing heretical and not approved of ? Wherefore, to speak the plain truth without flattery or partiality, I think of this new form of church government as some think of our bishop's regiment, namely, that it is but a device of man's conceit, and [only] there to be tolerated where a better cannot be obtained ${ }^{2}$.

In the body of the treatise, Saravia sets himself against the view that extraordinary measures were everywhere necessary for the reformation of the church :

As for the calling of those whom it hath pleased God to raise up for the reformation of his church, there be many which move many questions, and make more to do than they need : out of the which when they can no ways wind themselves, at all adventure they cast anchor in this unknown coast of extraordinary calling. But unless I be wondrously deceived, they do but ride in a shallow, and they need not.... How few, I pray you, have they been, whose calling was extraordinary...? And what then can the adversary object in this case against the church of England ? or wherein can it justly be challenged? May it not defend her calling ordinary, as may also many other churches in Germany ?... The church may be extraordinarily reformed (if so it be required) by them which have ordinary authority to reform

$$
1 \text { To the Reader. }
$$$$
2 \text { Ibid. }
$$ 


\section{Episcopacy and the Elizabethans}

it....At this day, if the bishops of the French churches would redeem themselves from the pope's tyranny, and sweep their churches clean of all error and idolatry, what need should they have of any other calling than that which they have ${ }^{1}$ ?

Accounting for the gradual rise of the episcopate, Saravia points out that some churches were complete at the apostles' death, others incomplete :

But whatsoever, or of what manner soever they were, they were all dependent upon the apostles' government: when if no man did succeed with like authority, it must needs be that they were all left as widow churches and orphans; which is an absurd thing to say. But if we shall say that they changed that manner of government with the which they were acquainted under the apostles, how could that possibly be permitted without the great mischief and misery of all those churches? Of these things therefore I infer that there was left of the apostles authority apostolic to their successors, whom they had disposed over many churches.... And those parts of apostolic government, as they were given of old to certain singular bishops, so are they to be given at this day where they are not given, and so are they to remain where they are given. If any man desire some reformation to be had in that kind, for my part I am not against it ${ }^{2}$.

Universality is to Saravia a proof of rightfulness :

That which we read to be done of all churches from the apostles' times, and of the fathers throughout the compass of the whole earth, and the same continued even unto these our days, I do always hold as a sacred canon of the apostles, not to be repealed. Neither is it a small presumption to abrogate that which hath been received with so great and universal consent; besides that it is in itself an uncouth declination of a conceit giddy and headstrong, it will also bring with it a greater mischief and misery to the church, than many at the first will conceive, or any in the end can relieve ${ }^{3}$.
${ }^{1}$ p. 9.
2 pp. 54 foll.
3 p. 55 . 
All the fathers which succeeded the apostles were not of opinion that the form of government they had received of the apostles should ever have been altered [i.e. was ever altered].... Were it not a point of frontless and ungracious insolency to deny that our fathers had their bishops and prelates, even from the apostles' times, and a part of needless and superfluous diligence to prove a thing so manifest, I might easily, and would willingly stay upon the citing and summoning of many more fathers, until we were fully compassed with a cloud of witnesses. But this is not the question: but rather it is now doubted whether the ordinance of bishops be of God or of men, as an order that slipped into the church, rather of human custom than divine constitution ${ }^{1}$.

There is nothing more certain than this, that the apostles ordained nothing in the church, which they received not of the Lord. But they created bishops (as Titus and Timothy), wheresoever need was in the church. And indeed had not the apostles created bishops, as they dispersed themselves throughout the whole world, how could ever the calling of bishops have been so universally approved by so general an assent of all cities? But when as many churches were infinitely distant from others, is it not strange that not any one church retained that divine kind of government (as it is thought) which is adored at this day in some reformed churches? Doubtless churches so diverse and distant could not but greatly differ in things indifferent, where there was no certainty set down by the apostles ${ }^{2}$.

This is without question and beyond all exception, that all the ancient authentic fathers, so many as held the right faith, were of this belief, that in this only plot they did follow the apostolic tradition and divine institution ${ }^{3}$.

Had not the orthodoctic fathers believed that the order of bishops was grounded upon the word of God, they would never have recounted the opinion of Aerius among other heresies ${ }^{4}$.

1 pp. 59, 60.

${ }^{3}$ p. 6 I.
2 p. 60.

+ p. 62. 
Saravia will not at all yield to the opinion of St Jerome, on which the new reformers relied so much :

I answer, that it was the private opinion of Jerome, consenting with Aerius, dissenting from the word of God.... That Jerome saith, how that bishops became greater than elders of custom rather than of any divine institution, it hath no semblance of truth....I say therefore that in the original of the church there was a time when they had nor elders nor bishops besides the apostles themselves, the evangelists and their fellow labourers (as in Crete, for the beginnings of all were alike). Shall we therefore say that those elders were set over the church of custom, not of any divine constitution, because the churches at the first, under the apostles, governed themselves without elders ?-or that, after they had abused that their popular kind of governance, that thereupon the government was committed to the council of elders of custom 1 ?

Albeit I should confess that the first occasion of creating one bishop over and above the rest of the elders was by reason of schism, notwithstanding it therefore followeth not that it was done for that cause only, or that it was not done of any divine institution. But the occasion of creation of bishops alleged by Jerome is a conjecture but too uncertain, and grounded upon no likelihood of reason; that for the offence of one church the apostles (contrary to the Lord's institution) should place one bishop over all the churches which had not offended, and that throughout the whole world, this were very hard....Without doubt, methinks, this was a vain motion, and an idle conceit of Jerome ${ }^{2}$.

Nothing could be more clearly pronounced than Saravia's conviction that episcopacy was of divine origin, and the fact that he dedicates his Defensio

${ }^{1}$ pp. 64-63 (paging wrong).

2 Ibid. p. 64. 
Tractationis to men like Bishop Aylmer, Bishop Cooper, and Bishop Fletcher, along with Archbishop Whitgift, indicates that he supposed his views to be in accordance with those of the church of England in general, not of an extreme party within it.

In the same year as the English translation of Saravia appeared (I592), Matthew Sutcliffe published his Treatise of Ecclesiastical Discipline.

The apostles, so long as they lived, ruled the church of God : they had the same committed to them by the head shepherd, Christ Jesus. When they were removed, who succeeded them in the government? whether the apostles' successors, or some others come we know not from whence? Sure, seeing bishops and ministers that led the church succeeded the apostles in their charge, as Cyprian and all antiquity acknowledgeth, it is absurd to attribute the authority and preeminence to others, that have neither right of succession nor other just claim of the place ${ }^{\mathbf{1}}$.

Sutcliffe's was not a great book, and it was much more occupied with destructive criticism of the Genevan position than with the elucidation of catholic principles. Nevertheless it shows plainly enough that the ordinary English churchman of the time was not afraid to maintain the same position as Saravia, - the divine credentials of episcopacy. He asks what right these new presbyters have to take up the authority of the apostles. All antiquity is on the side of the bishops:

Pastors or ministers of the word and sacraments all the ancient fathers have divided into bishops, and priests or elders. Whether bishops and elders be equal by the word 


\section{Episcopacy and the Elizabethans}

of God or not, we shall dispute hereafter. Sufficeth here that all antiquity hath distinguished bishops from priests. There can be no instance brought contrary, and therefore I need not here to prove it ${ }^{1}$.

\section{Sutcliffe sums up his argument thus :}

These conclusions may be inferred:

I. Seeing the fathers with one consent throughout the world received the constitution of bishops, that it came from the Spirit of God by the ministry of the apostles : for it is not the power of man that on a sudden can move men's hearts generally to receive one order established, but the effectual work of God's Spirit...2. Seeing the holy fathers say it is a divine institution, the babble of contentious fellows against such authority weigheth not so much as a pepper grain against a woolsack. If they were not very venturous, they would not hazard the reputation of their discipline against all antiquity. 3. That which ancient general councils, which this realm do approve, do decree, that it is not by every light fellow to be reproved; and rather doth he deserve stripes than words, that will disallow that which all general councils have allowed, not being contrariant to the word of God, which of those councils cannot be presumed. 4. Lastly, in taking upon them the patronage of Aerius and his opinions, condemned by the holy fathers for heresies, they discredit their discipline much, in acknowledging that it is condemned for heresy, and themselves for heretics ${ }^{2}$.

The publication of these two books drew forth, as has been already mentioned, a somewhat overbearing reply from Beza. To him, in I594, Saravia answered in the ponderous fashion of the time, paragraph by paragraph, defending Sutcliffe as well as himself. The Defensio, which is very lengthy, contains nothing fresh on the main topic, but it shows
1 p. 27.
${ }^{2}$ pp. $49 \mathrm{f}$. 
Saravia's wide outlook upon the church politics of the period. He feels, for example, that a willingness to throw episcopacy over would destroy all hopes of promoting a catholic reformation abroad. He says in his prefatory letter to the English bishops :

In meo tractatu... quicquid homines cogitent, non tantum vestras dignitates defendere in animo habebam, sed omnium ecclesiarum Christi, tam Galliae quam Germaniae episcopis, et aliis viris doctis et priscae ecclesiae gubernationis non ignaris, datas offensiones a nostris hominibus pluribus in locis, si non tollere, saltem minuere, et vulnus (quod nunquam sanabunt qui inflixerunt) lenire, et, quantum liceret, remoras propagationis doctrinae evangelicae amoliri conatus sum.

In his address to the Reader, he throws an interesting light upon the relations between the English church and the protestant churches on the continent. He says that he accepted office in the English church for the express purpose of showing the unity of those churches, which was endangered by the way in which the foreign protestants abetted the efforts of the innovators in England. While he was still in Holland, he says, he took every opportunity of requiting the generosity with which the foreign congregations in England were treated:

Quum igitur viderem optimos quosque non abhorrere a communione nostrarum ecclesiarum, similiter colendam mihi communionem cum ecclesiis Anglicanis in omnibus locis ubi vixi semper existimavi : et quandocumque me contigit in eorum adesse ecclesiis, quando coena Domini celebrabatur, sacra symbola pacis et unitatis Christianorum una cum eis percepi. Ita mihi iudicavi esse faciendum : quod tum ipsa 


\section{Episcopacy and the Elizabethans}

fides communis, tum quod omnes orthodoxi scriptores, tam veteres quam recentiores, id doceant, et semper docuerunt. A communione illius abhorrere ecclesiae, in qua Christus et per Christum nobis pacta gratia pure docetur, propter diversos externos ritus, magnae imbecillitatis iudicii, aut certe fastus et supercilii Pharisaici certum signum. Sed quod scripto et exemplo hic in Anglicana ecclesia aedificare volui, D. Beza responsione sua ad meum tractatum subruit et totum evertit.

Then, after showing the piecemeal fashion in which the reformation was effected in various countries, without consultation between the leaders, Saravia expresses his wish to see a kind of general council of the reformed churches, in which matters of this kind might be discussed. The wisdom of the English reformation would become apparent.

Re hinc inde disputata, quemadmodum in deliberationibus solet accidere, nemo a vicinis dedignetur, quod melius est et sibi deesse videt, accipere, aut resumere quod mutavit temere. Non enim credendum est primos plerosque authores reformationum ecclesiarum potuisse videre omnia, praesertim qui pauci fuere, et in magna rerum perturbatione et temporum id sunt aggressi. Quapropter ubi aliquid deesse videmus quod olim fuit in veris Christi ecclesiis, ferendum potius est quam maledictis insectandum. Quod me attinet, ego cum omnibus Christi ecclesiis...pacem et communionem retinere cupio. Nec enim propter externos ritus indifferentes et gubernationis ecclesiasticae diversam formam, quam forte non tam elegit libera voluntas quam introduxit temporum dura necessitas, ab ecclesia in qua nulla docetur impietas...secessio est facienda. Quod si morosuli quidam aliud sentiunt, fruantur per me proprii sensus deliciis: molestus eis non ero. Una me consolatur res, quod nullius novi dogmatis sum author: vetera, prisca, et antiqua defendo, observata $a b$ is quorum nomina nemo bonus non veneratur et colit. Inter ceteros qui reformarunt 


\section{Episcopacy and the Elizabethans}

ecclesias, saepe miratus sum sapientiam eorum, qui Anglicanae ecclesiae restituerunt verum Dei cultum, et ita se attemperarunt, ut nusquam decessisse $a b$ antiqua et prisca ecclesiae consuetudine reprehendi possint; ea moderatione usi sint, ut vicinos a reformatione non deterruerint, sed magis suo exemplo invitaverint : quam si alii fuissent secuti, minus bellorum civilium haberemus... . Sic enim secum recte cogitabant, se non esse primos Christianos.... Et profecto ita faciendum est omnibus, qui suam innocentiam Deo testatam et hominibus esse cupiunt.

It is a somewhat curious point that Saravia does not definitely discuss the question whether the power of ordination is confined to bishops. He everywhere assumes that it is so: for example,

Ad episcopos manuum impositionem restringi ab Epiphanio factum putat [Beza] ambitione episcoporum, quae tunc invaluerat contra Dei verbum, cum tamen nullum Dei verbum citet, et constet ex verbis Pauli ad Timotheum, quem praemonet ne cui cito manus imponeret,... id peculiare fuisse ordinanti ministrum ecclesiae ${ }^{1}$.

Ordinatio autem presbyterorum (quam mandatam fuisse Tito et Timotheo constat) episcopo ita propria semper ubique fuit, ut illas partes mandasse presbytero, qui episcopus non esset, nusquam legatur ; et idcirco non tantum a Hieronymo sed $a b$ omnibus veteribus theologis tanquam episcopi proprium notatur ${ }^{2}$.

The year I593 saw the publication of two important works against the puritan,- that is, the presbyterian,-propaganda. One was Bancroft's Survey of the Pretended Holy Discipline; the other was Bilson's Perpetual Government of Christ's Church. 


\section{Episcopacy and the Elizabethans}

Bancroft had maintained the divine institution of episcopacy, against the asserted divine institution of presbyterianism, in a sermon preached in 1589 , though he maintained it in very moderate language. $\mathrm{He}$ is said to have been the first to maintain that position; but it is not easy to define the difference between the view which he expressed in the sermon and that put forward by Jewel and Whitgift, or that of the ordinal itself. It is not to be supposed that the Survey was a withdrawal from the doctrine of the sermon, but the Survey does not claim a direct divine sanction for episcopacy. Bancroft was satisfied with showing that the episcopate was apostolic in its origin: apostolic to him was the same thing as divine. As against " parity" indeed, which was one of the main contentions of presbyterianism, Bancroft insisted that the principles of the Old Testament were against it, as well as those of the New.

Even as though they should have cast down their gauntlets and proclaimed an utter defiance to all the churches that ever were established in the world for much above three thousand years : the churches whilst the Law continued; the churches in Christ's time; the churches in his apostles' times; the churches throughout all Christendom for a thousand and five hundred years: against all the general councils: all the ancient fathers: and all ecclesiastical histories: against all the chief reformers of religion in this latter age :" against all the learned men's judgments before mentioned, and against all the reformed churches wheresoever in Christendom that either have bishops or superintendents. God forgive them this great sin of pride and presumption ${ }^{1}$. 
Bancroft was thankful to note that Beza had modified his unfavourable opinion of episcopacy :

But howsoever this course against bishops hath been carried on hitherto amongst them, God be thanked for some amendment.... And then to end this chapter :-Forasmuch as God himself appointed an inequality amongst the priests in the Old Testament... forasmuch as by Christ's institution and in his own time the apostles were superior unto the seventy disciples : forasmuch as the apostles, when the gospel began to spread itself, appointed sundry Timothies and Titus to govern the churches in divers countries and territories: forasmuch as all the ecclesiastical histories do record the superiority of bishops, and do set down the catalogues of many of them, and which of the apostles and apostolical bishops and in what cities and countries they succeeded: forasmuch as all the ancient general councils, and all the ancient and godly learned fathers, have allowed of bishops and of their superiority over the rest of the clergy : forasmuch as bishops have been accounted generally throughout the world to be the apostles' successors, and have continued in the church ever since the apostles' times : forasmuch as there was never any one of the ancient fathers, nor any learned man for I500 years but Aerius the heretic, that ever held that there ought to be no difference betwixt a bishop and a priest (I mean an ordinary minister of the word): and that his opinion was imputed unto him I200 years since by Epiphanius and St Augustine for an heresy: forasmuch as all the chief of the learned men that were the principal instruments under God in this latter age for the restitution of the gospel allowed fully of bishops and of their authority, and would most willingly have submitted themselves to their obedience, if they might have been received with any tolerable conditions... I see no reason why this anabaptistical dream of equality among pastors should not be sent back to the place from whence it issued ${ }^{1}$. 
Bilson's book, though controversial, was a more serious investigation of the questions at issue than Bancroft's. Like his, it traced the divine principle of a hierarchy back into the Old Testament. Like his, it was contented to show that episcopacy was apostolic in origin and catholic in history.

But were the word of God in this point indifferent, which for aught I yet see is very resolute against them, the general consent of all antiquity... is to me a strong rampire against all these new devices. I like not to raise up that discipline from the dead ${ }^{1}$, which hath lien so long buried in silence, which no father ever witnessed, no council ever favoured, no church ever followed since the apostles' time till this our age. I can be forward in things that be good, but not so foolish as to think the church of Christ never knew what belonged to the government of herself till now of late, and that the Son of God hath been spoiled of half his kingdom by his own servants and citizens for these I500 years without remorse or remembrance of any man that so great wrong was offered him. I can yield to much for quietness sake ; to this I cannot yield ${ }^{2}$.

The other four points of the apostolic delegation, which must have their permanence and perpetuity in the church of Christ, are the dispensing the word, administering the sacraments, imposing of hands, and guiding the keys to shut or open the kingdom of heaven. The first two, by reason they be the ordinary means and instruments by which the Spirit of God worketh each man's salvation, must be general to all pastors and presbyters of Christ's church: the other two, by which men are called to the ministry of the word, and obstinate persons... repelled from the society of saints... respect rather the cleansing and governing of Christ's church, and therefore no cause they should be committed to the power of every presbyter ${ }^{3}$.

${ }^{1}$ Bilson is allowing for the sake of argument that it once existed.

2 Perpetual Government, p. Io (ed. 1842).

3 Ibid. p. 12. 
What more pregnant probation can be required, than that the same power and precepts which Paul gave to Timothy, when he had the charge of Ephesus, remained in all the churches throughout the world, to certain special and tried persons authorised by the apostles themselves, and from them derived to their after-comers by a general and perpetual succession in every church and city, without conference to enlarge it, or council to decree it; the continuing whereof for three descents the apostles saw with their eyes, confirmed with their hands, and Saint John, amongst others, witnessed with his pen, as an order of ruling the church approved by the express voice of the Son of God ${ }^{1}$ ? When the original proceeded from the apostles' mouth, and was observed in all the famous places and churches of Christendom, where the apostles taught, and whiles they lived, can any man doubt whether that course of governing the church were apostolic? For my part, I confess, I am neither so wise as to over-reach it with policy, nor so wayward as to withstand it with obstinacy ${ }^{2}$.

Bilson speaks very clearly of grace accompanying the act of ordination (he is arguing against the layelders of Calvin's system : the argument might prove less efficacious against ordination by the other sort of elders) :

To create ministers by imposing hands is to give them, not only power and leave to preach the word and dispense the sacraments, but also the grace of the Holy Ghost to make them able to execute both parts of their function. This can none give but they that first received the same. They must have this power and grace themselves, that will bestow it on others. Laymen, which have it not, can by no means give it, and consequently not impose hands, which is the

1 This argument rests upon the identification of the "angels" of the seven churches of Asia with their bishops.

2 Perpetual Government, p. I4. 
sign and seal of both. Yea, what if to give power to preach and baptize be more than to preach and baptize? even as lawfully to authorize another to do anything is more than to do it ourselves.... They can have no part of the apostolic commission, that have no show of apostolic succession ${ }^{1}$.

The apostles both in teaching and governing the churches, when they were present, had helpers ; when they were absent, had substitutes ; after their final departures or deaths, left successors... Whiles they remained in or near the places where they planted churches, there was no such need of bishops, the apostles always supplying the wants of those churches with their presence, letters, or messengers, as the cause required. But when they were finally to forgo those parts, then began they to provide for the necessity and security of the churches, and left such fit men as they had, with episcopal power, to guide the churches which they had founded.... The best stories [i.e. histories] and writers of the primitive church do make them bishops, and likewise Paul's precepts to them the very patterns of episcopal charge and duty. Timothy, saith Eusebius, is by the stories reported to be the first that took the bishopric of Ephesus, as Tite also did of the churches in Crete 2 .

The things proper to bishops, which might not be common to presbyters, were singularity in succeeding, and superiority in ordaining. These two the scriptures and fathers reserve only to bishops: they never communicate them unto presbyters. In every church and city there might be many presbyters, there could be but one chief to govern the rest : the presbyters for need might impose hands on penitents and infants, but by no means might they ordain bishops or ministers of the word and sacraments. Neither are these trifling differences, as devised by me. The external unity and perpetuity of the church depend wholly on these. As to avoid schisms bishops were first appointed, so to maintain the churches in unity, the singularity of one pastor over each

1 Perpetual Government, pp. ז60, 162.

2 Ibid. pp. 277, 296, 302.

M. 
flock is commended in the scriptures. And as bishops preserve the unity of each church, in that there may be but one in a place, so they continue the same unto perennity, by ordaining such as shall both help them living, and succeed them dying ${ }^{1}$.

With regard to the divine authority of the episcopate, Bilson represents his opponents as urging thus :

If we should grant you that a difference was observed in the primitive church betwixt the presbyters and bishops, as well for ordination as succession, yet that difference grew only by the custom and use of the church, and not by any divine precept or ordinance. And so much is affirmed both by St Austin and St Jerome in those very places which you allege : for the church, as they say, and not Christ or his apostles, placed bishops in the seats and rooms of the apostles ${ }^{2}$.

\section{His answer is :}

When St Austin and St Jerome do say that the church createth and placeth bishops in the apostles' seats, they do not mean, as you misconstrue their words, that the church both altered the form of the apostolic government which she received, and of herself devised another kind of regiment by bishops; that were to charge the church of Christ with a voluntary defection from the apostles' discipline, and an arrogant preferring of her own invention before God's ordinance. With which though some in our times can be content to challenge the whole church of Christ, and even the apostles' coadjutors and scholars, yet Augustine and Jerome were far from that humour. Their meaning is that albeit the apostles be departed this life, who were worthily accounted fathers, because they were called immediately by Christ himself to convert and congregate his church, yet the church is not destitute, for so much as she hath power from God to create 


\section{Episcopacy and the Elizabethans 5I}

and appoint other of her children in their places, which are bishops. "Think not thyself forsaken," saith Austin to the church, "because thou seest not Peter and Paul, by whom thou wast begotten: of thine own offspring a fatherhood is grown unto thee. Instead of the fathers, children are born unto thee; thou shalt make them rulers over the whole earth ${ }^{1}$." He saith not the bishops are strangers or intruders on the apostles' possession; but, they are lawful children and rightly placed in their fathers' rooms, whose heirs and successors they are, though their vocation be not immediate from God, as the apostles' was ${ }^{2}$.

He discusses the teaching of Aerius, and says that St Austin

concurred in judgment with Epiphanius and Philastrius, and repelled that assertion of Aerius as repugnant to the doctrine and use of the whole church. And that confirmeth Epiphanius' opinion touching Aerius' positions, which were not Christian and catholic, as some men in our days begin to maintain, but rather arrogant and erroneous ${ }^{3}$.

Pressed by the catholic argument, the opponents admitted that by divine law there must be one chief pastor in each church. Bilson urges them accordingly :

Tell me now, I pray you, what difference betwixt chief pastors established in every city by God's law, as you are forced to grant, and bishops succeeding the apostles in their churches and chairs, as the fathers affirm. If you mislike the word "bishop," it is catholic and apostolic; if you mislike the office, it is God's ordinance by your own assertion.... You frame churches to your fancies, and then you straightway think the scriptures do answer your devices. If we give bishops anything which the ancient and catholic church of

1 Enarr. in Ps. xliv.

${ }^{2}$ Perpetual Government, p. $356 . \quad 3$ Ibid. p. 359. 
Christ did not first give them, in God's name spare us not; let the world know it. But if we prefer the universal judgment of the primitive church in expounding the scriptures touching the power and function of bishops before your particular and late dreams, you must not blame us. They were nearer the apostles' times and likelier to understand the apostles' meanings than you, that come after fifteen hundred years with a new plot of church government never heard of before. All the churches of Christ throughout the world could not at one time join in one and the self same kind of government, had it not been delivered and settled by the apostles and their scholars that converted the world. So many thousand martyrs and saints that lived with the apostles would never consent to alter the apostles' discipline, which was once received in the church, without the apostles' warrant. Wherefore we construe the apostles' writings by their doings; you measure the scriptures after your own heresies. Whether of us twain is most likely to hit the truth ${ }^{1}$ ?

It seems worth while to dwell at some length upon the testimony of this remarkable book-remarkable for its confident and uncompromising assertion of catholic principle in days so little favourable to the assertion,-even if it were only to serve as a contrast to the very cautious language of Bilson's contemporary, Hooker. The first four books of the Ecclesiastical Polity were published in I594, the year after Bilson's and Bancroft's books above mentioned. They do not contain any full discussion of episcopacy : shat was reserved for a later part of the work; but the subject is touched incidentally. Of the presbyterian system - at least of its claim to be scripturalHooker thought as poorly as Bilson or Bancroft.

1 Perpetual Government, pp. 367, 368 . 


\section{Episcopacy and the Elizabethans}

Our persuasion is that no age ever had knowledge of it but only ours; that they which defend it devised it ; that neither Christ nor his apostles at any time taught it, but the contrary. If therefore we did seek to maintain that which most advantageth our own cause, the very best way for us, and the strongest against them, were to hold, even as they do, that in scripture there must needs be found some particular form of church polity which God hath instituted, and which for that very cause belongeth to all churches, to all times. But with any such partial eye to respect ourselves, and by cunning to make those things seem the truest which are the fittest to serve our purpose, is a thing which we neither like nor mean to follow ${ }^{1}$.

He had no hesitation in thinking that episcopacy was in the closest accordance with scripture, but was only sorry for those who are without it:

For mine own part, although I see that certain reformed churches, the Scottish especially and the French, have not that which best agreeth with the sacred scripture, I mean the government that is by bishops, inasmuch as both those churches are fallen under a different kind of regiment; which to remedy it is for the one altogether too late, and too soon for the other during their present affliction and trouble : this their defect and imperfection I had rather lament in such case than exagitate, considering that men oftentimes without any fault of their own may be driven to want [i.e. to lack] that kind of polity or regiment which is best, and to content themselves with that which either the irremediable error of former times or the necessity of the present hath cast upon them ${ }^{2}$.

The parity upon which his opponents laid such stress seemed to him absurd :

1 Book III. x. 8 .

2 Book III. xI. I6. 


\section{Episcopacy and the Elizabethans}

The first thing in polity required is a difference of persons, without which those functions [the public religious duties of the church] cannot in orderly sort be executed. Hereupon we hold that God's clergy are a state which hath been and will be, as long as there is a church upon earth, necessary by the plain word of God himself ; a state whereunto the rest of God's people must be subject as touching things that appertain to their soul's health... Again, forasmuch as where the clergy are any great multitude, order doth necessarily require that by degrees they be distinguished, we hold there have ever been and ever ought to be in such case at leastwise two sorts of ecclesiastical persons, the one subordinate unto the other; as to the apostles in the beginning, and to the bishops always since, we find plainly, both in scripture and in all ecclesiastical records, other ministers of the word and sacraments have been. Moreover, it cannot enter into any man's conceit to think it lawful that every man which listeth should take upon him charge in the church : and therefore a solemn admittance is of such necessity, that without it there can be no church polity ${ }^{1}$.

In this large way Hooker lays out the ground for his exposition of the system of the church. It is a calamity that we are no longer sure how he expounded it in detail. Only with reserve can the seventh book be quoted as an expression of the views of Hooker ${ }^{2}$.

The uncertainty is all the more tantalizing because in this book Hooker-if the words are really hisdiscloses more of the process by which his mind had been formed than is usual with him. All doubt of the divine origin of episcopacy is over:

1 Book III. XI. 20.

2 See Dictionary of National Biography, s.v.; or Paget's Introduction to the Fifth Book, p. 262. 


\section{Episcopacy and the Elizabethans}

A thousand five hundred years and upward the church of Christ hath now continued under the sacred regiment of bishops. Neither, for so long, hath Christianity been ever planted in any kingdom throughout the world but with this kind of government alone: which to have been ordained of God, I am for my own part even as resolutely persuaded, as that any other kind of government in the world whatsoever is of God².

How the institution arose is a question which Hooker at one time would have answered otherwise than as he does now:

Now although [i.e. even if] we should leave the general received persuasion held from the first beginning, that the apostles themselves left bishops invested with power above other pastors:-although, I say, we should give over this opinion, and embrace that other conjecture, which so many have thought good to follow, and which myself did sometime judge a great deal more probable than now I do-merely [? namely] that after the apostles were deceased, churches did agree amongst themselves, for preservation of peace and order, to make one presbyter in each city chief over the rest ; .. this order, taken by the church itself (for so let us suppose that the apostles did neither by word nor deed appoint it) were notwithstanding more warrantable than that it should give place and be abrogated because the ministry of the gospel and the functions thereof ought to be from heaven ${ }^{2}$.

Hooker will not admit that there is any difference between the bishops of ancient days and ours: " to be a bishop is now the selfsame thing which it hath been "; " those things whereby they essentially differ from other pastors " are as " appliable" to them now as they ever were ${ }^{3}$. He shrewdly observes that the

${ }^{1}$ Book VII. I. 4. $\quad{ }^{2}$ Book VII. XI. 8. $\quad{ }^{3}$ Book VII. II. I. 


\section{Episcopacy and the Elizabethans}

office was probably in existence for some time before it was called by its present title; " generally things are ancienter than the names whereby they are called ${ }^{1}$."

A bishop is a minister of God, unto whom with permanent continuance there is given, not only power of administering the word and sacraments, which power other presbyters have, but also a further power to ordain ecclesiastical persons, and a power of chiefty in government over presbyters as well as laymen - a power to be by way of jurisdiction a pastor even to pastors themselves. So that...those things incident to his office, which do properly make him a bishop, cannot be common unto him with other pastors ${ }^{2}$.

The first bishops, Hooker affirms, were the apostles. Some of them even settled down to local supervision, like John in Asia, James at Jerusalem. "In process of time the apostles gave episcopal authority, and that to continue always with them which had it." Linus at Rome, Polycarp at Smyrna, Evodius at Antioch, were "their lawful successors," and so "all others who have it after them in orderly sort ${ }^{3}$." " Nor was this order peculiar unto some few churches, but the whole world universally became subject thereunto : insomuch as they did not account it to be a church which was not subject unto a bishop ${ }^{4}$." The apostles, in beginning this order, were assuredly moved by the "divine instigation and direction of the Holy Ghost," as St Paul was when he employed Timothy in episcopal affairs.

1 Book VII. II. 2.

3 Book VII. Iv.
2 Book VII. II. 3.

4 Book VII. v. 2 
Wherefore let us not fear to be herein bold and peremptory, that, if anything in the church's government, surely the first institution of bishops was from heaven, was even of God; the Holy Ghost was the author of it ${ }^{1}$.

When it comes to defining the peculiar powers of a bishop, Hooker will not admit that confirmation is peculiar to the bishop; but ordination is :

The power of ordaining both deacons and presbyters,the power to give the power of order unto others,-this... hath been always peculiar unto bishops. It hath not been heard of that inferior presbyters were ever authorized to ordain.... There are which hold that between a bishop and a presbyter, touching power of order, there is no difference. The reason of which conceit is, for that they see presbyters no less than bishops authorized to offer up the prayers of the church, to preach the gospel, to baptize, to administer the holy eucharist; but they considered not withal, as they should, that the presbyter's authority to do these things is derived from the bishop which doth ordain him thereunto, so that even in those things which are common unto both, yet the power of the one is, as it were, a certain light borrowed from the other's lamp'.

It is objected that presbyters are directed by a council of Carthage to join in the imposition of hands :

With us even at this day, Hooker answers, presbyters are licensed to do as much as that council speaketh of, if any be present. Yet will not any man thereby conclude that in this church others than bishops are allowed to ordain. The association of presbyters is no sufficient proof that the power of ordination is in them; but rather, that it never was in them we may hereby understand, for that no man is able

1 Book VII. v. Io.

${ }^{2}$ Book VII. vi. 3. 
to show either deacon or presbyter ordained by presbyters only, and his ordination accounted lawful in any ancient part of the church : everywhere examples being found both of deacons and of presbyters ordained by bishops alone oftentimes, neither ever in that respect thought insufficient ${ }^{1}$.

Like others before him, Hooker is obliged to consider the position of Aerius. He does not acquit him of heresy :

Are we to think Aerius had wrong in being judged an heretic for holding this opinion? Surely if heresy be an error falsely fathered upon scriptures, but indeed repugnant to the truth of the word of God, and by the consent of the universal church, in the councils or in her contrary uniform practice throughout the whole world, declared to be such; and the opinion of Aerius in this point be a plain error of that nature; there is no remedy but Aerius, so schismatically and stiffly maintaining it, must even stand where Epiphanius and Augustine have placed him.... His fault in condemning the order of the church, his not submitting himself unto that order, the schism which he caused in the church about it, who can excuse 2 ?

And yet it is to be observed that, in spite of the institution of episcopacy being apostolic and "by divine instinct," Hooker thought, as an abstract thesis, that it was not beyond the power of the catholic church to change it:

The whole body of the church hath power to alter, with general consent and upon necessary occasions, even the positive laws of the apostles, if there be no command to the contrary and it manifestly appears to her that change of times have clearly taken away the very reasons of God's first institution.... Bishops, albeit they may avouch with conformity

1 Book VII. vi. 5 .

2 Book VII. IX. 2, 4 . 


\section{Episcopacy and the Elizabethans}

of truth that their authority hath thus descended even from the very apostles themselves, yet the absolute and everlasting continuance of it they cannot say that any commandment of the Lord doth enjoin, and therefore must acknowledge that the church hath power by universal consent upon urgent cause to take it away, if thereunto she be constrained through the proud, tyrannical, and unreformable dealings of her bishops, whose regiment she hath thus long delighted in ${ }^{1}$.

Hooker went farther than this. He was prepared to admit that there were circumstances which justified, or compelled, even local churches to act without bishops.

Whereas hereupon some do infer that no ordination can stand but only such as is made by bishops which have had their ordination likewise by other bishops before them, till we come to the very apostles of Christ themselves,...t to this we answer that there may be sometimes very just and sufficient reason to allow ordination made without a bishop. The whole church visible being the true original subject of all power, it hath not ordinarily allowed any other than bishops alone to ordain: howbeit as the ordinary course is ordinarily in all things to be observed, so it may be in some cases not unnecessary that we decline from the ordinary ways ${ }^{2}$.

He holds that there are two ways in which men may be "extraordinarily, yet allowably" admitted to spiritual functions in the church. The first is where God, independently of the church, calls an agent whom he needs for his work, but ratifies the calling "by manifest signs and tokens himself from heaven." He gives no example of this class.

1 Book VII. v. 8.

2 Book VII. XIV. II. 
Another extraordinary kind of vocation is when the exigence of necessity doth constrain to leave the usual ways of the church, which otherwise we would willingly keep: where the church must needs have some ordained, and neither hath nor can have possibly a bishop to ordain; in case of such necessity the ordinary institution of God hath given oftentimes, and may give, place. And therefore we are not simply without exception to urge a lineal descent of power from the apostles by continued succession of bishops in every effectual ordination. These cases of inevitable necessity excepted, none may ordain but only bishops : by the imposition of their hands it is that the church giveth power of order, both unto presbyters and deacons ${ }^{1}$.

It is very noticeable that Hooker carefully avoids saying that in such extraordinary cases presbyters have a right to ordain. Doubtless if it had been necessary to answer the question he would have said that, failing bishops, they were the obvious persons to do it. But he prefers to give no rule for extraordinary cases: necessity, in his view, has no laws. He does not hold with the theory that presbyters are of one and the same order as bishops. Rightly or wrongly, he gives a different interpretation of the text of Jerome upon which that theory is founded. That nothing but ecclesiastical custom hinders presbyters from ordaining is a thesis to which Hooker gives no countenance.

In this, Hooker differs widely from Field. Field was, indeed, no latitudinarian. No man could express more forcibly the necessity of a lawfully appointed ministry in the catholic church :

1 Book VII. XIv. II. 


\section{Episcopacy and the Elizabethans}

The notes...that are inseparable, perpetual, and absolutely proper and peculiar, which perpetually distinguish the true catholic church from all other societies of men and professions of religions in the world, are three :-first, the entire profession of those supernatural verities which God hath revealed in Christ his Son; secondly, the use of such holy ceremonies and sacraments as he hath instituted and appointed...to separate his own from strangers; thirdly, an union or connexion of men in this profession and use of these sacraments, under lawful pastors and guides, appointed, authorized, and sanctified, to direct and lead them in the happy ways of eternal salvation.... They are inseparable, they are proper, and they are essential, and such things as give being to the church ${ }^{1}$.

But Field made himself the spokesman of the Hieronymian theory of episcopacy. No first-rate English church divine has so thoroughly identified himself with the opinion that the orders are not two, but one. He returns to the subject again and again. Quotations from so diffuse an author require pruning ; but nothing essential to Field's line of argument is omitted in the sentences that follow.

But [the Romanists] will say, whatsoever may be thought of these places wherein bishops did ordain, yet in many others none but presbyters did impose hands ; all which ordinations are clearly void: and so, by consequent, many of the pretended reformed churches, as namely those of France and others, have no ministry at all. The next thing therefore to be examined is, whether the power of ordination be so essentially annexed to the order of bishops that none but bishops may in any case ordain... The power of holy or ecclesiastical order is nothing else but that power which is specially given to men sanctified and set apart from others to perform certain

1 Of the Church, vol. I. p. 63 (E.H.S. ed.). 
sacred supernatural and eminent actions, which others of another rank may not at all, or not ordinarily, meddle with : as, to preach the word, administer the sacraments, and the like...

Now because the unity and peace of each particular church of God...dependeth on the unity of the pastor,... therefore, though they be many presbyters,... yet there is one amongst the rest, that is specially pastor of the place, who for distinction sake is named a bishop; to whom an eminent and peerless power is given,... and the rest are but assistants and coadjutors, and named by the general name of presbyters. So that... when he is present and will do ithe acts of ecclesiastical ministry] himself, they must give place ; and in his absence... they may do nothing without his consent and liking. Yea, so far for order sake is he preferred before the rest, that some things are specially reserved to him only, as the ordaining of such as should assist him in the work of his ministry,... and such like.

\section{Thus}

It will easily appear...that the power of ecclesiastical or sacred order... is equal and the same in all those whom we call presbyters,... and that only for order sake and the preservation of peace there is a limitation of the use and exercise of the same. Hereunto agree all the best learned amongst the Romanists themselves, freely confessing that that wherein a bishop excelleth a presbyter is not a distinct and higher order, or power of order, but a kind of dignity and office or employment only.... Hence it followeth that many things which in some cases presbyters may lawfully do are peculiarly reserved unto bishops.... Presbyters in some places and at some times did impose hands and confirm such as were baptized... . And who knoweth not that all presbyters in cases of necessity may absolve and reconcile penitents?... And why not, by the same reason, ordain presbyters and deacons in cases of like necessity ?... To bishops ordinarily the care of all churches is committed, and to them, in all reason, the 
ordination of such as must serve in the church pertaineth,... as long as they retain their standing.... If they become enemies to God and true religion, in case of such necessity, as the care and government of the church is devolved to the presbyters remaining catholic and being of a better spirit, so the duty of ordaining such as are to assist or succeed them in the work of the ministry pertains to them likewise... Who then dare condemn all those worthy ministers of God that were ordained by presbyters in sundry churches of the world, at such times as bishops in those parts where they lived opposed themselves against the truth of God and persecuted such as professed it ${ }^{1}$ ?

Again, towards the close of the book, Field repeats his contention :

Ordination is the setting of men apart to the work of the ministry, the commending of them with fasting and prayer to the grace of God, and the authorizing of them to perform things pertaining to God, which others without such sanctification neither may nor can do... The council of Carthage provideth that in the ordination of a presbyter, the bishop holding his hand on his head and blessing him, all the presbyters that are present shall hold their hands by the hands of the bishop.... So that other ministers are to concur in the ordination... as well as the bishop, being equal to him in the power of order and ministry and his assistants in the work of it ; yet hath the bishop a great preeminence above them in the imposition of hands; for regularly no number of presbyters imposing hands can make a minister without the bishop. The reason whereof is... not because the power of order which is given in ordination is less in them than in bishops. So that bishops alone have the power of ordination, and no man may regularly do it without them. Whereupon ordinarily, and according to the strictness of the old canons, all ordinations made otherwise are pronounced void: as we

1 Vol. I. pp. 318-323. The same arguments are repeated in vol. iII. pp. 2I 5 foll. 
64 Episcopacy and the Elizabethans

read of one Colluthus, whose ordinations were therefore voided, because he took on him to ordain, being no bishop, but a presbyter only ${ }^{\mathbf{1}}$. But seeing bishops and presbyters are in the power of order the same; as when the bishops of a whole church or country fall from the faith, or consent to them that do so, the care of the church is devolved to the presbyters remaining catholic; and as in the case of necessity they may do all other things regularly reserved to bishops only;... so in case of general defect of the bishops of a whole country refusing to ordain any but such as shall consent to their heresies, when there appeareth no hope of remedy from other parts of the church, the presbyters may choose out one among themselves to be chief, and so add other to their numbers by the imposition of his and their hands ${ }^{2}$.

There is truth and justice in Field's argument that in the ancient church the distinction between validity and canonicity was not fully established, and that many things were then treated as null and void which would now be considered valid though irregular.

All that may be alleged out of the fathers for proof of the contrary may be reduced to two heads. For first, whereas they make all such ordinations void as are made by presbyters, it is to be understood according to the strictness of the canons in use in their time, and not absolutely in the nature of the thing; which appears in that they likewise make all ordinations sine titulo void; all ordinations of bishops ordained by fewer than three bishops with the metropolitan; all ordinations of presbyters by bishops out of their own churches without special leave... . Secondly, their sayings are to be understood regularly; not without exception of some special cases that may fall out ${ }^{3}$.

1 In Athanasius' Apology.

${ }^{2}$ Vol. IV. pp. I48-I 5 I.

s Vol. I. p. 324. Cp. vol. III. p. 218. 


\section{CHAPTER III}

\section{UNDER JAMES I AND CHARLES I}

IN the year I608 George Downham, afterwards Bishop of Derry, preached a sermon on episcopacy which led to further study of the subject. A Defence of the sermon appeared in I6II; and both sermon and Defence are referred to with great respect by all subsequent writers of that and the following age. The result is thus stated in the Defence:

Though in respect of the first institution there is small difference between an apostolical and divine ordinance, because what was ordained by the apostles proceeded from God (in which sense and no other I do hold the episcopal function to be a divine ordinance,-I mean in respect of the first institution), yet, in respect of perpetuity, difference by some is made between those things which be divini and those which be apostolici juris ; the former, in their understanding, being perpetually, generally, and immutably necessary ; the latter not so. So that the meaning of my defence plainly is that the episcopal government hath this commendation above other forms of ecclesiastical government, that in respect of the first institution it is a divine ordinance; but that it should be such a diyine ordinance as should be generally, perpetually, immutably, necessarily observed, so as no other form of government may in no case be admitted, I did not take upon me to maintain ${ }^{1}$.

1 Defence of Sermon, 1. 4, cap. 6, p. 139 (quoted by Stillingfleet Irenicum, P. 4I5).

M. 
Two great names in English theology connect the Elizabethan days with those of Charles I ; they are the names of Andrewes and Overall.

Andrewes, by five years the elder of the two, had preached the Convocation sermon in I593, the year in which Bilson's Perpetual Government was published. He was then a chaplain of Whitgift's. Andrewes is quite clear that a belief in the divine sanctions of episcopacy was not the private opinion of a few Anglicans, but the doctrine of the church itself. He tells the Romanist :

Our church doth hold, there is a distinction between bishop and priest, and that de jure divino ${ }^{1}$.

He bears the same testimony in his correspondence with Pierre Du Moulin, the French protestant divine. $\mathrm{Du}$ Moulin complained that King James had objected to three assertions in his Vocation des Pasteurs, (a) that the name of bishop and presbyter are used in the New Testament indiscriminately, $(b)$ that presbyters and bishops are one order, $(c)$ that the preeminence of the bishop is not of divine right. He felt it all the harder that he should have been censured, because he had given offence to his brethren at home by maintaining that the institution of bishops over the presbyters had begun immediately after the apostles' time, and was a good thing in itself. Andrewes replies, perháps rather severely, that all English churchmen agreed with the king:

Regis hic animus, animus itidem (ut par est) noster est omnium.

1 Answer to Perron (Minor Works, p. 29, Anglo-Cath. Libr.). 


\section{Under James I and Charles I}

The first of $\mathrm{Du}$ Moulin's assertions Andrewes allows. Of the second he says:

Proximum est de Ordine. Ubi vide, quaeso, an idem ordo dicendus sit, cujus eadem non sint munia. Non esse autem eadem munia, vel qui minus aequi hic sunt fatentur, dum ordinationem semper excipiunt. Dein an unus idemque dicendus sit, ubi non sit una eademque sed nova et diversa manuum impositio: manus enim episcopis impositas in omni antiquitate nemo, opinor, inficias iverit.

It was argued by some that the use of the word " consecration" in making bishops, instead of " ordination," showed that a separate order is not contemplated. Andrewes has no difficulty in proving that the word "ordain" is frequently used by the fathers in speaking of the making of bishops. Then he proceeds :

Atqui nos apostolorum et lxxii discipulorum scimus duos ordines fuisse eosque distinctos. Et id quoque scimus, passim apud patres haberi ad eorum exemplum episcopos et presbyteros. Apostolis successisse episcopos, septuaginta duobus presbyteros. Duos hos ordines in duobus illis a Domino constitutos....

Hinc aditus nobis patefit ad ultimum, an hic ordo de jure divino. Laetus autem lubens legi magnam apud te semper fore antiquitatis auctoritatem. Amo te de verbo hoc. Nec erit in minimis laudum tuarum, si dictis facta responderint. Ego quidem sic sensi, sic semper affectus fui.

He then pours out a heap of historical proofs that the apostles appointed the first bishops in their lifetime, and adds :

Spero, quod apostoli fecerunt, divino jure fecisse ; neque negari posse eorum facta (de quibus quidem constat), non 
dicta solum vel scripta, divini juris fuisse. Nec quae scripsit [Paulus] ad Corinthios modo, sed et cetera illa quae Corinthum veniens disposuit (si de iis nobis liqueret) pari jure fuisse, divino scilicet et haec et illa, a Spiritu Divino utraque.

But Andrewes carefully adds the caution, that episcopacy, after all, is not an article of faith, but of order :

Nec tamen, quia divini juris sunt, ideo fidei capita dicenda sunt. Ad agenda ecclesiae spectant haec; ad credenda autem aut capita fidei non nisi improprie revocantur ${ }^{\mathbf{1}}$.

In $A$ summary view of the Government both of the Old and New Testament whereby the Episcopal Government of Christ's Church is vindicated, Andrewes put together, and tabulated, after his manner, a number of facts which led up to this conclusion :

Last of all, that the churches thus planted and watered might so continue, the apostles ordained overseers to have a general care over the churches instead of themselves who first had the same.... Upon these was transferred the chief part of the apostolic function, the oversight of the church ; and power of commanding, correcting, and ordaining.

The occasion which caused the apostles to appoint bishops [besides the pattern in the time of the Law] seemeth to have been schisms,... for which St Cyprian, St Jerome, and all the fathers take the respect to one governor to be an especial remedy ${ }^{2}$.

\section{He adds :}

The very same power this day remaineth in the church, and shall to the world's end.

1 Opuscula, pp. 178 foll.

2 Minor Works (ed. 1846), p. 355. 


\section{Under James I and Charles I}

After speaking of the helpers of the apostles, who journeyed with them, " and supplied their absence in divers churches when they themselves were occasioned to depart," Andrewes observes :

To two of these, Timothy and Titus, the one at Ephesus, the other at Crete, the apostles imparted their own commission while they yet lived, even the chief authority they had :

to appoint priests

to ordain them by imposition of hands...

And these after the apostles deceased succeeded them in their charge of government which was ordinary, successive, and perpetual (their extraordinary gifts of miracles and tongues ceasing with them)...

These were they whom posterity called bishops: but in the beginning regard was not had to distinction of names; the authority and power was ever distinct, the name not restrained, either in this or other.

At the end of the notes, Andrewes says of the bishop :

Upon him lieth

to take care of the churches under him...

To him was committed

Authority of ordaining... and so begetting fathers... for though St Paul should mention a company with him at the ordaining of Timothy, yet it followeth not but that he only was the ordainer; no more than that Christ is the only judge, although the twelve shall sit with him on thrones ${ }^{1}$.

Yet, with all his insistence upon the divine right of bishops, Andrewes was not prepared to make episcopacy absolutely indispensable. To Du Moulin he writes:

1 Minor Works (ed. 1846), p. 36r. 


\section{Under James I and Charles I}

Quaeris tum peccentne in jus divinum ecclesiae vestrae. Non dixi. Id tantum dixi, abesse ab ecclesiis vestris aliquid quod de jure divino sit; culpa autem vestra non abesse, sed injuria temporum. Non enim tam propitios habuisse reges Galliam vestram, in ecclesia reformanda, quam habuit Britannia nostra ; interim, ubi dabit meliora Deus, et hoc quoque quod jam abest per Dei gratiam suppletum iri. At interea episcopi nomen, quod tam saepe in sacris est, abolendum non fuisse. Quanquam quid attinet abolere nomen, retinere rem? Nam et vos rem retinetis sine titulo; et illorum uterque quos nominabas ${ }^{1}$, dum vixerunt, quid erant nisi abolito nomine re ipsa episcopi ${ }^{2}$ ?

The evidence of facts was too strong the other way:

Nec tamen si nostra [forma] divini juris sit, inde sequitur vel quod sine ea salus non sit, vel quod stare non possit ecclesia. Caecus sit qui non videat stantes sine ea ecclesias. Ferreus sit qui salutem eis neget. Nos non sumus illi ferrei ; latum inter ista discrimen ponimus. Potest abesse aliquid quod divini juris sit (in exteriore quidem regimine) ut tamen substet salus.... Non est hoc damnare rem, melius illi aliquid anteponere. Non est hoc damnare vestram ecclesiam, ad formam aliam, quae toti antiquitati magis placuit, i.e. ad nostram revocare ${ }^{3}$.

Upon the question of communion with such defective churches Andrewes does not enter.

A very important action in which Andrewes took part leaves us somewhat uncertain as to his own explanation of it. This was the consecration of the Scottish bishops in I6ro. One of them, Spotswood or Spottiswood, who had then long borne the title of Archbishop of Glasgow, has left his own brief but
1 Calvin and Beza.
2 Opuscula, p. $2 \mathrm{II}$.
3 Ibid. p. r9I. 


\section{Under James I and Charles I}

clear account of what took place. King James summoned him and two other titular bishops to London, and informed them that he had with great difficulty recovered the bishoprics with their status and endowments,

but since he could not make them bishops, nor could they assume that honour to themselves, and that in Scotland there was not a sufficient number to enter charge by consecration $^{1}$, he had called them to England, that being consecrated themselves they might give ordination to those at home, and so the adversaries' mouths might be stopped, who said that he did take upon him to create bishops and bestow spiritual offices, which he never did nor would he presume to do, acknowledging that authority to belong to Christ alone and those he [Christ] had authorised with his power.

Spotswood professed his willingness to comply, and that of his brethren, but said that in Scotland it might be interpreted as a sort of subjection to the church of England. James answered that he had provided against that by keeping the English archbishops out of the business, and appointing only the Bishops of London (Abbot), Ely (Andrewes), and Bath (Montague), to consecrate them ${ }^{2}$.

The narrative continues:

A question in the meantime was moved by Dr Andrewes, Bishop of Ely, touching the consecration of the Scottish bishops, who, as he said, "must first be ordained presbyters,

1 This seems to imply that there were still one or two bishops, but not the canonical number. So far as 1 know there were none.

2 As a matter of fact the consecrators were Abbot, Andrewes, Neile of Rochester, and Parry of Worcester. They acted under licence from Archbishop Bancroft. 
as having received no ordination from a bishop." The Archbishop of Canterbury, Dr Bancroft, who was by, maintained, "that thereof there was no necessity, seeing where bishops could not be had, the ordination given by the presbyters must be esteemed lawful ; otherwise that it might be doubted if there were any lawful vocation in most of the reformed churches." This applauded to by the other bishops, Ely acquiesced, and at the day and in the place appointed the three Scottish bishops were consecrated ${ }^{1}$.

This seems a simple and straightforward account ; and there is nothing in it which does violence to what we know of the opinions of Bancroft or of Andrewes. Heylin, however, in his Aerius Redivivus, gives a different version of what Bancroft said. He says that the archbishop argued

that there was no such necessity of receiving the order of priesthood, but that episcopal consecration might be given without it ${ }^{2}$.

Heylin's connexion with Laud, and Laud's with Andrewes, give some value to his testimony. There is no reason why the same man should not have used both arguments ascribed to Bancroft, or why Andrewes should have been compelled to choose between them. It has been asserted that Andrewes did not hold with consecrations per saltum, and must therefore have assented to the validity of the presbyterian orders. It would be interesting to learn where Andrewes' opinion on consecrations per saltum is to be found. We know that he did not reject presbyterian

1 Spotswood's History of the Church of Scotland, book vir. (p. 5I4, ed. r668).

2 Aerius Redivivus, p. $3^{87}$. 


\section{Under James I and Charles I}

orders as wholly invalid where others were not to be had. He may well have felt that consecration to the episcopate might cover any deficiency in them. The one thing certain in the matter is that he would have preferred to ordain Spotswood and his companions priests before consecrating them, and that he would not have considered such a proceeding to be a sacrilegious reordination. Doubtless the knowledge that this was his view had influence when next the question came up for consideration, and in the Scottish consecrations of I66I the precedent of I6Io was set aside and the two candidates who had received only presbyterian orders were ordained priests before being made bishops.

Overall's Convocation Book is assigned by Cosin to the year I606, when the author was Prolocutor of the lower house of the Canterbury Convocation. It possesses no authority, but some part of it, at any rate, was accepted by the Convocations of both provinces as expressing the mind of the English church. Overall goes beyond Andrewes, indeed perhaps beyond any other theologian, in implying that not only the three orders are to be traced to divine inspiration, but the whole hierarchy. His great thesis is that the government of "God's catholic church" and that of "the kingdoms of the whole world " are parallel to each other, under one Head, namely Christ.

In respect of Christ our Redeemer, all that believe in his name, wheresoever they are dispersed, are but one catholic church.... Our Saviour Christ having made the external 
government of his catholic church suitable to the government of his universal monarchy over all the world, hath by the institution of the Holy Ghost ordered to be placed in every kingdom...archbishops, bishops, and inferior ministers, to govern the particular churches therein planted; priests or ministers in every particular parish, and over them bishops within their several dioceses, as likewise archbishops to have the inspection and charge over all the rest, according to the platform ordained in substance by himself in the Old Testament ${ }^{1}$.

Others before Overall had maintained that the hierarchical principle established under the Levitical law was continued under the New Covenant, but none perhaps had pressed it so far.

We do verily think that if our Saviour Christ or his apostles had meant to have erected in the churches amongst the Gentiles any other form of ecclesiastical government than God himself had set up amongst the Jews, they would have done it assuredly in very solemn manner, that all the world might have taken public notice of it.... But in that they well knew how the form of the old ecclesiastical government in substance was still to continue... amongst Christians, as soon as they should become for number sufficient bodies and ample churches to receive the same;...they did in the meanwhile, and as the time did serve them, attempt the erecting of it in such sort and by such fit and convenient degrees as by direction of the Holy Ghost they held it most expedient,...till such time as the work was in effect accomplished $^{2}$.

Overall traverses the usual ground in describing how the apostles were drawn

to provide for a succession in their ministry, of fit persons sufficiently authorized by them to undertake that charge,

1 Convocation Book, p. 205 (Oxford, 1844).

2 Ibid. p. 132. 


\section{Under James I and Charles I}

and as well to yield some further assistance unto them whilst they themselves lived, as afterwards; also, both to continue the same in their own persons unto their lives' end; and in like manner to ordain by the authority of the apostles given unto them other ministers to succeed themselves; that so the said apostolical authority, being derived in that sort from one to another, there might never be any want of pastors and teachers... unto the end of the world ${ }^{1}$.

If the apostles did not communicate to others the "three essential parts" of the ministry, viz. power to preach, to administer the sacraments, and authority of government (wherein must be degrees, some to direct, and some to be directed), then these essential parts

died all with them, which were a very wicked and idle conceit, the apostles having power to communicate them all alike, as by their proceedings will appear ${ }^{2}$.

The apostles used special legates, like Timothy and Titus :

and these were the persons who were afterwards, when they were tied to the oversight of divers particular churches or congregations, termed bishops ${ }^{3}$.

"A second degree of ministers" were ordained for local work ;

only they wanted power and authority of ordination to make ministers, and of the apostolical keys to excommunicate ${ }^{4}$.

These two prerogatives the apostles kept in their own hands. They were near enough to the various churches to administer them in person or through

1 Convocation Book, p. 133.

2 Ibid. p. 134 .

3 Ibid. p. 135.

4 Ibid. p. 136. 
their legates. In those days there was no need of any other bishops besides the apostles; but in process of time

they did commit their said two prerogatives, containing in them all episcopal power and authority, unto such of their said coadjutors as upon sufficient trial of their abilities and diligence they knew to be meet men.... Of this authority of ordination and government given to bishops by the holy apostle St Paul, he himself hath left to all posterity most clear and evident testimonies, where writing to two of his said bishops, Timothy and Titus, he describeth very particularly the essential parts of their duties and episcopal office ${ }^{1}$.

\section{Nor was this only a temporary arrangement :}

It is most apparent by the testimonies of all antiquity, fathers, and ecclesiastical histories, that all the churches in Christendom that were planted by the apostles and by such their coadjutors... did think...that the same order and form of ecclesiastical government should continue in the church for ever. And therefore upon the death of any of them, either apostles or bishops, they, the said churches, did always supply their places with others the most worthy and eminent persons amongst them; who, with the like power and authority that their predecessors had, did ever succeed them.... It savoureth assuredly, we know not of what faction, indiscretion, or affection, for any man either to think that form of government to be unfit for our times that was held necessary for the apostles' times, or that order... should be necessary to build the church, but unfit to preserve it....For aught we can find, there can no one nation or country be named since the apostles' days, neither in times of persecution nor since, but, when it first received the faith of Christ, it had thereupon both bishops and arch-

1 Convocation Book, pp. 138 foll. (Oxford, 1844). 


\section{Under James I and Charles I}

bishops placed in it for the government of the churches that were there planted ${ }^{1}$.

Coming to the subject of ordination, Overall says :

The primitive churches presently after the apostles' times, finding in the New Testament no one person to have been ordained a priest or minister of the gospel, mediately by men, but either by imposition of the apostles' hands, or of their hands to whom they gave authority on that behalf, ... and knowing that the church of Christ should never be left destitute of priests and bishops for the work of the ministry ; they durst not presume upon their own heads to devise a new form of making ministers, nor to commit that authority unto any other, after their own fancies, but held it their bounden duty to leave the same where they found it, viz. in the hands of Timothy and Titus, and consequently of other bishops their successors.... None of the primitive churches or ancient fathers did ever so much as once dream that the authority given...to...bishops, as well for the ordering of priests as for the further order and government of the church, did determine by the death of the apostles;... and ever since, till very lately, it was held by them altogether unlawful for any to ordain a priest or minister of the word, except he were himself a bishop; and no one approved example for the space of above fifteen hundred years can be observed, for aught we find, to the contrary. It is true that one Colluthus, being himself but a priest, would needs take upon him to make priests;... and that the like was attempted by one Maximus, supposing himself to have been a bishop, where he was indeed but a priest... . Howbeit such their ordinations were accounted void and utterly condemned as unlawfui ; they themselves not escaping such just reproof as so great a novelty and presumption did deserve. We acknowledge that for the great dignity of the action of ordination it was decreed...that priests should

1 Convocation Book, pp. 147 foll. 
lay their hands, with the bishop, upon him that was to be made priest ; but they had not thereby any power of ordination, but only did it to testify their consent thereunto, and likewise to concur in the blessing of him: neither might they ever in that sort impose their hands upon any without their bishops ${ }^{1}$.

To this rule Overall apparently knows no exception. He does not indeed discuss in this work the validity of foreign protestant orders, but the animus seems unfavourable to them. His "canon" is as sweeping in this as in other things :

If any man shall affirm...that when the ancient fathers did collect out of the scriptures and practice of the apostles the continuance for ever of that form of church-government which was then in use, they were not so thoroughly illuminated with the Holy Ghost as divers men of late have been ; ... or that any since the apostles' times, till of late days, was ever held to be a lawful minister of the word and sacraments, who was not ordained priest or minister by the imposition of the hands of some bishop; or that it is with any probability to be imagined that all the churches of Christ and ancient fathers from the beginning would ever have held it for an apostolical rule that none but bishops had any authority to make priests, had they not thought and judged that the same authority had been derived unto them, the said bishops, from the same apostolical ordination that it was committed unto Timothy and Titus, their predecessors ; ...he doth greatly err ${ }^{2}$.

Yet there is evidence to show that this was not Overall's real opinion, when it came to practical politics. Birch, in his Life of Tillotson, gives this interesting information :

1 Convocation Book, p. 150.

2 Ibid. pp. 155 foll. 


\section{Under James I and Charles I}

I have now before me a long letter of [Bishop Overall's] secretary Mr John Cosin, afterwards Bishop of Durham, containing many curious particulars relating both to Antonio de Dominis, Archbishop of Spalato, and Bishop Overall ; of whom I shall mention one fact... of which $\mathrm{Mr}$ Cosin himself was witness. Dr De Laune, who translated the English liturgy into French, being collated to a living and coming to the bishop, then at Norwich, with his presentation, his lordship asked him where he had his orders. He answered that he was ordained by the presbytery at Leyden. The bishop upon this advised him to take the opinion of counsel, whether by the laws of England he was capable of a benefice without being ordained by a bishop. The doctor replied that he thought his lordship would be unwilling to reordain him, if his counsel should say that he was not otherwise capable of the living by law. The bishop rejoined,

"Reordination we must not admit, no more than rebaptization: but in case you find it doubtful, whether you be a priest capable to receive a benefice among us or no, I will do the same office for you, if you desire it, that I should do for one who doubts of his baptism, when all things belonging essentially unto it have not been duly observed in the administration of it, according to the rule in the book of Common Prayer, If thou beest not already etc. Yet for mine own part, if you will adventure the orders that you have, I will admit your presentation, and give you institution unto the living howsoever."

But the title which this presentation had from the patron proving not good, there were no farther proceedings in it ; yet afterwards Dr De Laune was admitted into another benefice without any new ordination ${ }^{1}$.

1 Birch Life of Tillotson, pp. I7o foll. Birch (or Cosin) does not say whether the other benefice was also in Overall's diocese. I have been unable to discover anything more about De Laune. He was, no doubt, related to William De Laune, physician and divine, who died in r6ro (see Dict. of Nat. Biogr.). Cosin would not be inclined 
Overall seems to have felt that others might take a more strict view of these matters than he did. $\mathrm{He}$ wrote to Grotius in I6I7 :

I believe there are few things in your book which will not be approved of by the Bishop of Ely [Andrewes] and the rest of our more learned divines: unless, perhaps, they may hesitate respecting those passages which seem to give to lay powers a definitive judgment in matters of faith, to deny the true power and jurisdiction of pastors of the church, and to rank episcopacy among unnecessary things. For our divines hold that right of definitive judgment in matters of faith is to be given to synods of bishops and other learned ministers of the church, chosen and convened for this purpose, according to the usage of the ancient church, who shall determine from the holy scriptures, explained by the consent of the ancient church, not by the private spirit of neoterics ${ }^{1}$.

Curiously bound up with Overall in this matter was a distinguished scholar who began his career under the patronage of Archbishop Abbot-a man generally considered to belong to a very different school from that of Overall.

Mason was the first of the line of writers who have made the validity of Anglican orders a subject of scientific study. The first edition of his book Of the Consecration of the Bishops in the Church of England was printed in $\mathrm{I}_{6} \mathrm{I} 3$, with a dedication to Archbishop Abbot, who had encouraged him in the undertaking. In the course of this dedication,

to minimise the compliance shown by Overall. The inaccuracy of his statement about Whittingham in the same context is shown by Birch from Burnet on p. I72.

1 Epistolae praestantium et eruditorum Virorum, p. 486. The translation is that of Bishop Jebb (Sermons, p. 396). 


\section{Under James I and Charles I 8I}

Mason, after speaking of the holy ministry of the word and sacraments as being like the rivers of Paradise, " which holy function, flowing from Christ, as from the fountain, to his blessed apostles, was by them derived to posterity," goes on to say that it was by the special providence of God that this ministry was preserved amidst the darkness of popery, " including a ghostly ministerial power to forgive sins " by means of the word and the sacraments.

Then Mason points to the great difference between the course of the reformation abroad and its course here :

For whereas in other countries the bishops, which should be stars and angels of the church, did resist the reformation and persecuted such as sought it, it pleased God that in England, among other bishops, Archbishop Cranmer, the chiefest prelate of the kingdom, was God's chiefest instrument to restore the gospel, which afterwards he sealed with his blood. The event whereof was that, whereas other reformed churches were constrained by necessity to admit extraordinary fathers, that is, to receive ordination from presbyters, which are but inferior ministers, rather than to suffer the fabric of the Lord Jesus to be dissolved, the church of England had always bishops to confer sacred orders, according to the ordinary and most warrantable custom of the church of Christ. And although in Queen Mary's time five blessed bishops were burned to ashes, yet God reserved to himself a number, which... in the happy reign of Queen Elizabeth returned again... and with holy imposition of hands ordained bishops, presbyters, and deacons in the church of England ${ }^{1}$.

1 Mason's Vindication of the Church of England (ed. 1728). pp. xlvii foll. 
These ordinations had been slandered by "reproachful papists," who said that our ministers are merely laymen ; and

some popish recusants have been so confident that they have professed that, if we could justify our calling, they would come to our churches, and be of our religion. The consideration whereof (Most Reverend Father) gave me occasion to wade into this controversy, being desirous, next the assurance of my own salvation as I am a Christian, to be fully and clearly assured of my calling as I am a minister... . It is verily to be hoped that all such [as made scruple to enter our orders, because of the Roman calumnies against them] shall receive singular comfort, when they see our calling justified, not only in itself as the true ministry of the gospel, but also in regard of the derivation to us by such bishops and in such manner as is most correspondent to the sacred scripture and the practice of primitive antiquity ${ }^{1}$.

The book takes the form of a dialogue between Orthodox, an Anglican priest, and Philodox, a Roman. The definition of a bishop as given by Orthodox is this :

A bishop in the ecclesiastical sense hath three properties. For first, he receiveth his episcopal power by imposition of the hands of bishops. Secondly, for the execution thereof he is confined to a certain place. And thirdly that, having a singular and supereminent authority over the other ministers of the church, he should govern his church, by ordaining ministers, and exercising the censures of binding and loosing ${ }^{2}$.

Orthodox makes no difficulty of calling ordination a sacrament :

1 Vintication of the Church of England, p. xlviii.

2 Ibid. p. 28. 


\section{Under James I and Charles I}

If the word sacrament be extended to every external sign instituted of God, whereto is annexed a promise of grace, then we will grant with St Augustine and others that holy orders may be called a sacrament; but if it be taken strictly for... a sign of justifying grace annexed to the promise of forgiveness of sins, in this sense there are but two sacraments of the New Testament.... The grace given in ordination is of another nature, respecting not so much the good of the receiver, as that of the flock for whose sake he receiveth it. For the ministers of the Gospel are the salt of the Lord to season others, candles to shine unto others, and the pipes and conduits to convey unto others the wells of water springing up into everlasting life ${ }^{1}$.

The gifts of priesthood come by succession :

The priesthood which the apostles conferred was only a spiritual power to minister the word and sacraments, which being conveyed to posterity successively by ordination is indeed found at this day in some sort in the church of Rome, ... in regard whereof you may be said to succeed the apostles, and Cranmer you, and we Cranmer ; and consequently we also in this succeed the apostles as well as you².

\section{The character conferred by ordination is in- delible :}

If by an indelible character be meant only an everlasting gift of God, or a certain spiritual power never to be reiterated, then we may safely confess that in baptism and holy orders there is imprinted an indelible character.... If a priest lawfully ordained should become a schismatic or heretic,... and afterwards be reclaimed, he is not to be re-ordained; but if the church shall need his labours, and hold it convenient that he execute the ministerial function, she may allow him to perform it by virtue of his orders formerly received, which still remain entire and indelible.

${ }^{1}$ Vindication of the Church of England, p. 38 ; cp. p. 169.

${ }^{2}$ Ibid. p. 46. 
So much for a priest. Now to transfer our speech from a priest to a bishop ; shall his iniquity hinder him from giving true orders? No, verily; for there is the same reason of both. There is so; for as Christ our Lord is the chief baptizer, so he is also the chief ordainer, for it is he that giveth pastors and teachers for the perfecting of the church ${ }^{1}$.

Mason has an instructive passage about the episcopal succession in England before the reformation :

Phil. Was not Cranmer the father and progenitor of your church and religion, from whom all your ordinations are derived?

Orth. Of our religion? No, Philodox, by no means, nor any other but God the Father, Son, and Holy Ghost. For Christ himself is the author of our orders, from whom the power of ordaining others, flowing as from a pure fountain first to the apostles, next, from the apostles, ran down to the bishops as its conduit-pipes; who at first being golden, and afterwards silver, at length, as the metal was debased and corrupted, became in some measure leaden. The orders therefore, which at first were clear as crystal,... became thick and muddy, and so came down to Cranmer.... But under Edward VI the form of ordination was purged and strained off from the dregs of popery which it had contracted :... whence it happily came to pass that Cranmer afterwards conferred more pure orders, and left the ordinal so reformed to his successors. Wherefore, if we speak with respect either to the successions of the ordainers or the more pure form of ordination, I own we derive our ordinations from Cranmer....

Phil. Now advance to the second step, and answer me, whether those who ordained Cranmer were not bishops of the Roman church?

Orth. Of the Roman? No, but of the English church ${ }^{2}$.

1 Vindication of the Church of England, p. I53.

2 Ibid. pp. 165 foll.; cp. pp. 168, 173, 344, 565. 
Mason is quite clear that only bishops are empowered to ordain :

'Tis plain from the scriptures that there ought to be ministers in the church, even till the perfecting of the saints. Secondly, those sacred writings do clearly point out to us three degrees of ministers, to wit, deacons, priests, and bishops. Thirdly, the functions and offices of all these are distinctly and clearly enough explained in the scripture. Fourthly, St Paul teaches us that these ministers are not to be ordained by any or every body, but only by the Tituses or Timothies, that is to say, by bishops ; for though there were many priests both in the church of Crete and Ephesus, yet he did not allow them the power of ordaining, but sent Titus to Crete and Timothy to Ephesus for this very cause. Fifthly, 'tis most certain that these orders are conferred by the laying on of hands'.

No one could rate more highly the bishop's spiritual jurisdiction. "The immediate fountain thereof," Mason says, "is God himself." Philodox asks when and how, if that be so, it is derived from Christ to our bishops. Orthodox replies:

As they are made bishops, so have they their jurisdiction. And they are made bishops by consecration. Therefore when they are consecrated, they receive their jurisdiction. For the party to be consecrated is presented to the archbishop by two bishops in these words: "Most reverend father in God, we present unto you this godly and well learned man to be ordained and consecrated bishop." In which form the word bishop is taken in the usual ecclesiastical sense, to signify a Timothy or a Titus, a star or an angel of the church. And soon after, the archbishop with the other bishops present layeth on hands, saying, " Receive the Holy Ghost," that is, such ghostly and spiritual power or grace of

1 Vindication of the Church of England, p. 192. 
the Holy Spirit as is requisite to this end, to advance a presbyter to the office of a bishop. So that in these words here is given to the new bishop whatsoever belongeth to the episcopal office, as the prayers going before this laying on of hands... do manifestly declare. Wherein we make humble petition to almighty God for his blessing and grace, that he may duly execute the office of a bishop, faithfully serve therein, and minister episcopal discipline. You see here, the church of England corffers not only the ministerial function in general, but in particular the ministration of discipline also, that is to say, the power of jurisdiction, by the means of consecration ${ }^{1}$.

\section{With regard to the ordination of priests Mason} teaches that the empowering to remit sins contains everything :

The third point which you require me to prove (to wit, that these words, "Receive the Holy Ghost; whose sins thou dost forgive, they are forgiven," etc., do make a complete ordination of a priest) is thus made out. First, it is agreed that these words do confer a ministerial power of forgiving sins. But this power makes a complete ordination of a priest. For that is said to be a complete ordination of a priest, which comprehends the whole function of a priest... What other functions can there be peculiar to a priest besides the preaching of the word and the due administration of the sacraments? And both these are included in this ministerial power of forgiving sins... Whomsoever therefore Christ hath entrusted with the power of forgiving sins, the same hath he honoured and vested with the authority to minister the word and sacraments. Whence it appears that those words do comprehend the whole and complete ordination of a priest, though implicitly and covertly ${ }^{2}$.

1 Vindication of the Church of England, p. 368.

2 Ibid. p. 570. 
He argues forcibly that the articles sent by Queen Mary to Bonner show that in her days ordination according to the Edwardian ordinal was not treated as wholly null :

Here you see Queen Mary's bishops did not ordain our ministers anew, but only supplied what they thought wanting in them.... This construction which I put upon that article is fair and friendly, as it reconciles the papists in Queen Mary's time with Bellarmine, and at the same time acquits them of the foul charge of reordination $\mathbf{1}$.

All this is mixed with a good deal that must have puzzled the Bishop of Paris, to whom Mason dedicated the Latin edition of his book; but it is enough to show that Archbishop Abbot, Mason's patron, was able to bear with fairly strong doctrine on the apostolical succession.

Several years before his Vindication against the papists was printed, Mason had vindicated, though more briefly, the Anglican system against the puritans. In a sermon preached in 1605 he said :

Our opposites do glance at us as though the orders and ceremonies of our church were not apostolic. To which I answer that those apostolic times we honour and reverence, not only for doctrine, which then did run most clear, as being nearest to the crystalline fountain, but also for discipline, so far as the state of those days could possibly suffer. But though the doctrine of the apostles be fully set down in the apostles' writings, yet the discipline is not so. The reason whereof is because the doctrine is one and the same, eternal and unchangeable, and therefore it is called an everlasting gospel: but the discipline, especially the

1 Vindication of the Church of England, pp. 574 foll. 
ceremonies, is for the most part variable, according to circumstance of time and place. Therefore the whole doctrine is purposely and plentifully, the discipline only in part, by occasion, and sparingly, delivered in holy scripture; and consequently what the orders apostolic were cannot be fully known by the apostolic writings. And yet of those which are known the grand and main points are observed in the church of England; as namely, among other, the government by bishops, and the ceremony of laying on of hands in making of ministers ${ }^{1}$.

The foreign reformers were no compulsory model for England :

They propose us the pattern of reformed churches which have rejected these ceremonies, as though it were our duty therein to follow them.... Concerning the reformed churches, I beseech God to pour his blessings and Spirit upon them and make them like the thousands of Manasses and the ten thousands of Ephraim. It is true they have rejected some ceremonies which we retain: the things were indifferent, and they have used their Christian liberty in refusing them, and we the like liberty in using them. But why should we be bound to their example?... Diversity of rites in divers churches independent doth no harm where there is an unity of faith : it only shows that the King's daughter, so that she be glorious within, may be clothed with garments of changeable colours. Yet we cannot but marvel that men will urge us to conformity with foreign churches, to which we owe no subjection, and will not conform themselves to their own mother, the church of England ${ }^{2}$.

Considerable uncertainty attaches to the authorship of a little pamphlet, published in I64I under Mason's name by John Dury in the same collection

1 Appended to the Vindication (ed. 1728), p. 602.

2 Ibid. p. 6I5. 
that contained Usher's Original of Bishops. It bears on the title-page the title The Validity of the Ordination of the Minis[t]ers of the Reformed Churches beyond the seas, maintained against the Romanists, by Francis Mason. Mason had died twenty years before, and Dury gives no indication of the way in which he came by the little work. Lindsay, the translator and editor of Mason's Vindication, indignantly repudiates the attribution of the pamphlet to Mason, which he thinks to be wholly out of keeping with Mason's doctrine. But Lindsay was unaware that others had ascribed the Validity of the Ordination beyond the Seas to an even greater authority than Mason's. George Davenport, writing to Sancroft in 1655 and the year following, ascribed it on Cosin's authority to Overall, and said that Overall had had a hand also in the composition of Mason's greater book. Mason was a dignitary of Overall's diocese of Norwich, and the two men were likely to work together in such matters ${ }^{1}$.

1 The letters are in the Bodleian, MS. Tanner 52, f. Io3 and f. I 52. The first is as follows :

Sir,

$$
\begin{aligned}
& \text { PARIS, } \\
& \text { Jan. 26, I655. }
\end{aligned}
$$

Our last letters, I hope, are safely come to your hands, and yours, I hope, will be in ours before this cometh to you........ $\mathrm{Y}^{\mathrm{e}}$ Dean [of Peterborough, John Cosin] is well, but I cannot trouble him at present so much as I would, because of his course of preaching. I learnt of him $y^{e}$ other day $y^{t} y^{e}$ book wherin $y^{e}$ ordination of $y^{e}$ French church is vindicated, was made by Bishop Overall (with whom $\mathrm{y}^{\mathrm{e}}$ Dean $\mathrm{y}^{\mathrm{n}}$ lived) and not by Mr Mason. Mr Mason indeed added something to it, with $\mathrm{y}^{\mathrm{e}}$ approbation of $\mathrm{y}^{\mathrm{e}}$ Bishop, and printed 
The pamphlet is called, at the heading of it, " the addition of Francis Mason unto" his former work. It is in fact a continuation of the dialogue between the papist and the Anglican, and has just the same bright style. Philodox admits that there is somewhat to be said for " the ministers of England," but challenges his friend to defend Luther, Calvin and their disciples. Orthodox would rather refer this

it in his own name at $\mathrm{y}^{\mathrm{e}}$ desire of $\mathrm{y}^{\mathrm{e}}$ Bishop whose Chaplain (I think) he was. $\quad \mathrm{Y}^{\mathrm{e}}$ Dean, $\mathrm{I}$ think is of $\mathrm{y}^{\mathrm{e}}$ same mind [i.e. about the French orders]. Thus wishing you all happiness, I take my leave till this day sennight, and rest

Your assured lov. Fr. and servant, G. D.

If it is true that Mason himself printed the addition, the first edition has perished. Dury's edition is the earliest in existence. Davenport corrects and supplements the information above given in a second letter.

SIR,

Yours of July I6th, I received about a week since : and deferred to trouble you with another till this time, because of Mr Beaumonts absence. I heard of $\mathrm{Mr} \mathrm{R}$. G. wellfare at Paris in a lettre from D. C. [i.e. Dr Cosin] he is gone from thence with Sir Ed. Mansell towards Lion: and God go with him. I have received 2 lettres from $\mathrm{y}^{\mathrm{e}}$ Doctor not much in them to be communicated: but I must undeceive you about $\mathrm{y}^{\mathrm{e}}$ additionalls to Mr Mason: for, he saith, he said, $\mathrm{y}^{\mathrm{t}} \mathrm{y}^{\mathrm{e}}$ Bishop was $\mathrm{y}^{\mathrm{e}}$ chiefe composer of $\mathrm{y}^{\mathrm{e}} \mathrm{I}^{\text {st }}$ draught of $\mathrm{y}^{\mathrm{e}}$ book (de minist. Anglic.) in English, which was printed at London by Bill $\mathrm{y}^{\mathrm{e}}$ Kings printer. He is very angry at Mr Fuller, and will let him know how much he is injured by him : for he purposeth to print his answer to $y^{\mathrm{e}}$ articles against him in $\mathrm{y}^{\mathrm{e}} \mathrm{L}^{\mathrm{ds}}$ house. My brother came not hither as I expected.......

Your affectionate Friend and Servant,

D. G. (Geo. Davenport*)

Aug. 6. 1656.

[Endorsed] For Mr Sandcroft.

[* In Sancroft's handwriting.] 


\section{Under James I and Charles I}

point to the learned men living in the foreign churches themselves, who are better acquainted with the particulars of their own estate; nevertheless, lest Philodox should "insult and triumph over our brethren," he has no objection " to skirmish a little" with him.

After showing that the early foreign reformers were no Aerians, by the respect with which they wrote of bishops, Orthodox plunges boldly into the question whether the episcopal order is an order at all. The argument is an argumentum ad hominem, and Orthodox conducts it wholly by reference to schoolmen and later divines of the Roman church. Philodox avers that the bishop's intrinsecal power to ordain rests, not upon his jurisdiction, but upon his actual order.

If it can be proved, is the answer, out of your own writers, that every presbyter hath as much as a bishop of the sacrament and character of order, you must confess that every presbyter hath intrinsecal power to give orders ${ }^{1}$.

It is certainly a great muster of names and quotations which answer to the summons of Orthodox. The Master of the Sentences acknowledges only two " sacred orders," deaconship and priesthood. Bonaventure says that the episcopal consecration impresses no character. Aquinas denies that "the bishop's function " constitutes an order. Durandus, Soto, Richard, Aureolus, say in effect the same. Navarrus says that there are only seven orders, 
not nine, according to the ordinary calculation; because the first tonsure is not an order, nor is " the bishoply function," but only an office. Then follow a whole " cloud of witnesses," ending with the catechism of the council of Trent, which, like Navarrus, says that there are seven orders of ministers in the catholic church, beginning with the ostiarius and rising to sacerdos, but making no mention of a bishop. Finally Bellarmine's variations of opinion on the subject are traced, and he is shown to have returned in the latter part of his life to the conviction of his earlier days, that presbyters and bishops are one order, though of divers degrees ${ }^{1}$.

It comes to this, that according to the teaching of Antonius de Rosellis, consecration to the episcopal office is not the conferring of new powers upon the man who is consecrated, but the liberation of powers which he had before, which had been hitherto restrained, " as the faculty of the flying of a bird when his wings are tied." But, Philodox argues, at least the restraint was jure divino. Orthodox answers:

First, if you mean by jure divino that which is according to the scripture, then the preeminence of bishops is jure divino; for it hath been already proved to be according to the scripture. Secondly, if by jure divino you mean the ordinance of God, in this sense also it may be said to be jure divino, for it is an ordinance of the apostles, whereunto they were directed by God's Spirit, even by the Spirit of Prophecy, and consequently the ordinance of God. But if by jure divino you understand a law and commandment of God, binding all Christians universally, perpetually,

1 Validity, etc., p. I57. 


\section{Under James I and Charles I}

unchangeably, and with such absolute necessity, that no other form of regiment may in any case be admitted, in this sense neither may we grant it, nor yet can you prove it, to be jure divino ${ }^{1}$.

Philodox then asks pertinently what authority Luther had to untie the wings of the presbyters. Orthodox answers that it was not voluntary in him, but a case of necessity, and proceeds again to argue from Roman divines on what can be done in case of necessity,--Rosellus again closing the list, who says, "I hold that the pope may give commission to presbyters to confer all sacred orders, and in this I stand with the opinion of the canonists." Orthodox shows the impossibility of obtaining episcopal ordination at the outset of the foreign reformation, and justifies the more recent procedure on the ground that these churches have established for themselves bishops, or officers who for this purpose are equivalent to bishops, by whom their ordinations are performed.

Wherefore seeing a bishop and a presbyter do not differ in order, but only in preeminence and jurisdiction, as yourselves acknowledge; and seeing Calvin and Beza had the order of priesthood, which is the highest order in the church of God; and were lawfully chosen, the one after the other, to a place of eminency and endued with jurisdiction derived unto them from the whole church wherein they lived; you cannot with reason deny them the substance of the episcopal office. And whereinsoever their discipline is defective, we wish them even in the bowels of Christ Jesus by all possible means to redress and reform it, and to conform themselves to the ancient custom of the church of Christ,

1 Validity, etc., p. 163. 
which hath continued from the apostles' time, that so they may remove all opinion of singularity and stop the mouth of malice itself $\mathbf{1}$.

Another writer of the period who defended the church of England against the Romanists was Crakanthorp. Crakanthorp's Defensio Ecclesiae Anglicanae, perhaps somewhat oddly selected for reprinting in the Anglo-Catholic Library, is a more markedly protestant book than Mason's. First published in I625, after the author's death, it was called forth by the onslaught of the adventurer, Mark Antony de Dominis, after his return to the Roman communion. Crakanthorp repudiates the names of Calvinist, Lutheran, and Puritan, which De Dominis bestows on the adherents of the English church. We are catholics,- catholics and nothing else: the church to which De Dominis belonged is at best " Romanocatholic," and is in fact heretical.

Sed est et aliud quod a te verbo hic monendum censeo. Frequens tibi in ore est, sed a daemone injecta, et malignitate summa a vobis ejecta calumnia, quod per opprobrium nos Calvinianos, Lutheranos, et Puritanos vocitetis. Non est hoc novum ; fecerunt hoc idem haeretici majores vestri : passi sunt et olim similem nobiscum calumniam orthodoxi. Sanctissimi illius Ephesini concilii patres orthodoxi ad unum omnes et catholici: a Nestorianis tamen et ipsorum tum Ephesi collecto conciliabulo...Cyrilliani, ut nos a vobis Calviniani, dicti sunt....

1 Validity, etc., p. 175. It is to be observed that Mason goes expressly on the ground that Calvin and Beza had the order of priesthood. It seems certain that neither of them was ever ordained priest. 


\section{Under James I and Charles I}

Lutherum nos et Calvinum, ut conservos nostros, doctrina, pietate, et constantia insignes honoramus. Beata erit apud pios bonosque omnes eorum memoria, et ut unguentum odoratum diffundentur per ecclesiam Dei ipsorum et nomina et encomia.... Sed nos eos honoramus ut servos Dei, non ut fidei dominos....Calvini scripta et Lutheri sic recipimus, quomodo olim Cypriani literas Augustinus: "Quod in eis divinarum scripturarum authoritati congruit, cum laude ejus accipio ; quod autem non congruit, cum pace ejus respuo."... Nos quia non sic Luthero aut Calvino [ut vos Papae] addicti, Lutherani aut Calvinistae nec sumus nec nisi per calumniam vocamur.... Nos simpliciter et sine additione catholici ${ }^{1}$.

De Dominis affirmed that the church of England could not but be heretical, because it freely admitted to communion anabaptists and puritans. Crakanthorp entirely denies the first charge, and only admits the second with a qualification :

Ais nos " ab haeresi tam Puritanorum quam Anabaptistarum immunes esse non posse, quia cum illis plene etiam et perpetuo communicamus: non damnamus eos, non vitamus, non excludimus a sacris nostris conventibus, sed in divinis nobiscum communicare permittimus." Primum hoc est, quo ecclesiam Anglicanam haereticam esse probes, argumentum. Credo equidem te ex eis quae ante audisti, quam in hac calumnia et mendacio effrons sis et inverecundus, satis intelligere. Ain' ecclesiam hanc sacrosanctam plene cum Anabaptistis et perpetuo communicare? eos non damnare, non excludere ? sed ad sacra nostra et conventus sacros admittere? O hominem ex mendaciis et calumniis totum conflatum !...

At saltem Puritanos non damnamus: cum is plene et perpetuo communicamus. Imo non plene, non perpetuo: sed et eos, quoties de delicto cujusvis constat, a communione

1 Defensio, pp. 188 foll. (ed. r847). 


\section{6 \\ Under James I and Charles I}

nostra excludimus, nec vel uno verbo, ut ante docui, laedi ab ipsis ecclesiae nostrae authoritatem vel dignitatem impune sinimus. Si vel in ritus solum nostros et disciplinam contumacius se efferant, castigamus eos severe, et pro meritis suis ac delicti ratione virgam sentiunt et supplicium. Quod si ultra progrediantur et haeresin insuper aut fovere aut disseminare incipiant, et haeresin eorum damnamus et ipsos. Nam quod tu, opinor, plane ignoras, est haeresis quaedam Puritanorum, nec in ritus solum peccant, ut tu opinaris, sed non nunquam etiam in fidem ipsam et dogmata. Certe enim proprie eorum haeresis eadem ex parte est, quae fuit Aerii ${ }^{1}$.

He next shows what, in his opinion, the heresy of Aerius consisted in, and how the English church will not allow of it :

Illius haeresin indicat Augustinus: "Dicebat presbyterum ab episcopo nulla differentia debere discerni."... Paritatem verbo divino institutam, praeceptam, et mandatam dixit; imparitatem verbo divino damnatam dixit. Ideoque non praxin modo sed et judicium universalis ecclesiae, in qua saeculis omnibus, in ecclesiis item omnibus, imparitas illa admissa erat, damnavit; etiam ut verbo Dei repugnans damnavit. Nos contra imparitatem episcopi et presbyteri non damnari in verbo Dei, sed permitti, imo approbari dicimus; etiam ab apostolis ipsis et institutam fuisse et approbatam dicimus et constanter docemus... Qui in haeresi Puritanorum, illi vere in hoc Aeriani ideoque vere haeretici sunt. Eos ecclesia Anglicana et scriptis, eisque doctissimis, refutat, et si quando ex his ulli in ea inveniantur, dignis eos ac justis suppliciis coercet. Tu tamen fronte adamantina non erubuisti asserere ecclesiam Anglicanam cum Puritanis et Puritanorum haeresi plene communicare ${ }^{2}$.

1 Defensio, pp. 225 foll.

2 Ibid. pp. 226 foll. 
But Crakanthorp denies that either the English puritans or the foreign reformers were Aerians in the heretical sense :

Nec ecclesia solum Anglicana, sed nec illi, si qui forte in Anglia Puritani, licet ab ecclesia nostra in hoc dissentiant, Aeriani quidem sunt; ne illi, inquam, hierarchiam nostram ut repugnans sacris literis condemnant.... Sed et ab hac Aerii et Puritanorum haeresi illi ipsi immunes, qui tibi maxime omnium Puritani habentur. Lutherum dico, Calvinum, Bezam, et reformatas omnes ecclesias. Non habent illi, scio, distinctos a presbyteris eisque in ordinandi et excommunicandi potestate superiores episcopos. At imparitatem tamen istam, quod fecit Aerius, non verbo Dei repugnare docent, non damnant eam vel in nostra vel in universali per annos supra mille quingentos ecclesia. Per verbum Dei et jus divinum liberum et licitum utrumvis censent, utrum paritatem ordinum admittant an imparitatem. Rectene hic an secus sentiant, non est in animo hic disserere. Nihil hoc ad Aerium aut Aerii, de qua nune ago, haeresin. $\mathrm{Ab}$ illa haeresi quantum absint, ex ipsorum scriptis tu nunc judica ${ }^{1}$.

The foreign reformers had no choice in the matter :

Vides nunc luce clarius, quam longe absint ecclesiae omnes reformatae, omnesque in iis docti ac prudentes viri, ab illa Aerii, quam toties nobis exprobratis, haeresi. Ille inaequalitatem inter episcopum et presbyterum damnabat: hi probant. Ille episcopalem authoritatem penitus extinguere ; hi, quantum in eis erat, eandem conservare desiderabant. Ille universalis ecclesiae judicium et praxin in hoc repudiavit, et ut verbo Dei repugnans damnavit; hi universalis ecclesiae et judicium et praxin putant quidem esse praeter sed non contra verbum Dei, nec ab eo dissonum, ideoque et laudant et magnopere probant. Et quod te

1 Defensio, pp. 227, 228.

M. 
praecipue observare velim, ille fastu ac ambitione inflatus paritatem istam in totam ecclesiam introducere cupiebat; hi necessitate compulsi paritatem in suis solum ecclesiis admittere vestra perversitate coacti sunt. Unum hoc et durum necessitatis quo tum premebantur telum multa quae post consequuta sunt fecit legitima, quae remota necessitate fuissent culpanda.... Claves suas apostoli episcopis commendarunt, nec ab aliis quam episcopis legitime unquam antea usurpatae. Aerarium Christi aperire noluerunt quaestores Romani: " nullos ad pascendi munus admittere volebant, nisi jurent se puram evangelii doctrinam nolle docere." Aut violandum tum erat aeternum illud Christi mandatum, "Praedicate evangelium," et "Pasce oves meas," aut claves a privatis, Scipionis exemplo; arripiendae erant... Optamus quidem ex animo, ut cum lex illa necessitatis jam ablata sit, velint et omnes ecclesiae ad priscum et $\mathrm{ab}$ universali ecclesia constantissime observatum ordinem et ordinandi modum redire clavesque suas episcopis restituant: sed optamus, non cogimus. Jus et imperium in eorum ecclesias nec habemus nos nec desideramus. Sic vero illi istam calumniandi ansam vobis praeriperent, quam per admirabilem suam et providentiam et bonitatem in ecclesia Anglicana Deus praevertit ${ }^{1}$.

Not all communion with heretics involves a church in complicity with their heresy :

Communicare cum haeretico, quando se haereticum esse prodit, haereticum est, teque, si ei communices, haereticum demonstrat. Communicare cum lupo ovis pelle induto, cum haeretico catholicam fidem licet ficte profitenti, non excusabile solum est, sed et laudabile, teque si ei, dum talem se gerit, communices, catholicum demonstrat.

Si Anabaptista quis, si vel Papista, sacris nostris se ingerat, quia is suo hoc facto se nostrum esse, se catholicum esse profitetur, nos eundem ut nostrum, ut catholicum reci-

1 Defensio, pp. 230 foll. 


\section{Under James I and Charles I}

pimus. Quam primum ille latens in visceribus ipsius virus ac venenum evomere incipit, in judicia pertrahimus, et sceleris convictum damnamus, rejicimus, anathematizamus ${ }^{1}$.

That the English church is in communion with the foreign reformed churches Crakanthorp does not for a moment deny: he glories in her hospitality to refugees from abroad :

Ecclesia, inquis, Anglicana communionem publice et aperte profitetur cum Genevensi aliisque ultramarinis ecclesiis... Quare cum Anglicana cum his haereticis ecclesiis communionem teneat, erit et ipsa quoque haeretica. Imo nec Anglicana est, nec illae haereticae.... Inter multa et illustria beneficia, quibus pro infinita sua bonitate Anglicanam ecclesiam beavit Deus, hoc non in postremis ducimus, quod nobis illius servos, fratres et conservos nostros, sub Antichristi jugo olim gementes, per saevitiam nunc et tyrannidem vestram pulsos patria et natali solo, bonis ac fortunis exutos, omnibus exhaustos jam casibus, omnium egenos, urbe, domo sociare dedit. Fuisse scimus, et gratissimis animis saepissime recolimus, cum Marianis illis temporibus eadem haec humanitatis simul ac pietatis officia a Gallis, a Belgis et Germanis, cumulate benignoque animo in se praestita sensit nostra Anglia. Ingemiscimus quidem nunc eorum casibus; quia tamen per vos et tyrannidem vestram profugi illi nunc sunt, laetamur ex animo, quod Anglia nostra portus ipsis ac perfugium esse queat. Et si centesimo cum foenore ipsorum in nos benignitatem ac beneficia rependere possimus, hoc magis honori nobis ducimus, etiam et beneficio ${ }^{2}$.

It is a blessed work to endeavour to draw the reformed, yet catholic, churches into union with each other and with the Anglican church : 
Lutherani, inquis, plurimarum haeresium sorde polluti sunt: cum Lutheranis vero communicare Anglicana synagoga paratissima est, et plurimum conatur, ut monstra haec in unum cum ipsa coalescant, unioque fiat omnium ecclesiarum reformatarum. Certe quidem conatur hoc ecclesia Anglicana. Unionem omnium et optat et efficere laborat. $\mathrm{Nec}$ poteras tu aut quivis illustrius ullum aut dignius Anglicanae ecclesiae encomium excogitare. Quis unquam pius aut prudens non omnium ecclesiarum catholicarum unionem optet? Et si uspiam dissidium contingat, quis bonus non pro virili illud extinguat? Beatos esse pacificos pronunciavit Christus. Beata ecclesia Anglicana, quae vel hoste judice pacifica ${ }^{1}$.

The church of Scotland has had several learned and peacemaking divines of the name of Forbes. Of these, John Forbes of Corse, professor of divinity at Aberdeen, was one of the holiest and wisest. His Irenicum was published in I629. The part of it which deals with the question of church government begins with the divine right of episcopacy :

Disputant quidam fratres, sitne praesidentia et regimen episcopale juris divini an humani sive ecclesiastici. Et quia praecipui hujus disceptationis inculcatores hunc sibi habent propositum finem, ut praesidentiam et regimen episcopale contemnant et ex ecclesia eliminent, primo loco quaerendum $\mathrm{ab}$ eis, num omnis humana constitutio sit abominanda et contemni sine culpa possit aut debeat. Hoc si asserant, convincuntur manifesti erroris ; sin autem ingenue fateantur... quid, obsecro, obtinebunt pro fine illo suo assequendo, etiamsi largiremur praesidentiam et gubernationem episcopalem jure ecclesiastico esse introductam, cum licitis ecclesiae constitutionibus obedientiam de jure divino debeamus $^{2}$.

1 Defensio, p. 239.

2 J. Forbesii Opera Omnia (Amsterdam, 1703), vol. I. p. 409 (bis). 


\section{Under James I and Charles I IOI}

On the question of history Forbes had no doubt :

Episcopos jure divino presbyteris praeesse nemo primis ecclesiae Christianae et quidem multis seculis dubitasse aut de ea re disceptasse legitur praeter Aerium et Hieronymum presbyteros ; quorum alter, nempe Aerius, est propter suam opinionem haereticus judicatus... alter vero, nempe Hieronymus, nunquam propterea est haereseos insimulatus. Itaque discrimen aliquod fuisse oportet inter opinionem Aerii haereticam et opinionem Hieronymi.

The difference was, he says, that Jerome, on the one hand, reverently submitted to the law of the church, and approved of it,--sometimes even maintaining that the bishop's prerogative was divine; but Aerius said that it was wrong for such prerogative to exist. The presbyterians therefore were mistaken in claiming Jerome as on their side, while endeavouring to get rid of episcopacy out of the church.

Forbes' next step is to quote reforming authorities who contended, like Jerome, that the episcopate is a merely ecclesiastical institution, yet found no fault with it. Calvin, Zanchius, Rivet, are among the number. Clearly, he says, it at least comes under the general law of Christ, that if any one refuses to hear the church, he puts himself in the position of the heathen ${ }^{1}$.

A whole series of propositions on the subject follows next.

I. Ea est ministerii evangelici ratio de jure divino, ut ei non repugnet ministrorum disparitas, sed possit ei congruenter convenire. 
II. De jure divino est, ut sit sociale ministerium, hoc est, ut unusquisque pastor societatem aliquam pastorum agnoscat, cui subjectionem et obedientiam debeat.

III. Juris divini est, ut singulae societates, sive collegia pastorum, suas certas habeant regiones et limites, jam post apostolos.

IV. De jure divino necessarius est societati sive collegio pastorum praeses aliquis et moderator, qui authoritate publica instructus reliquos convocet, et cum is judicia exerceat ecclesiastica, clericos ordinet...cui reliqui subjici in Domino et obedire tenentur, se legitime gerenti in sua $\pi \rho \sigma \sigma \tau a \sigma i a$.

In enforcing this fourth proposition Forbes enlarges somewhat. He says:

Semper in ecclesia, jam inde a primis initiis, fuit aliqua auctoritas personalis (quam episcopalem vocamus), potestatem habens praesidendi coetui simplicium presbyterorum. Christus praeerat apostolis, non solum dominica potestate qua servis, et magisteriali qua discipulis, sed etiam episcopali qua presbyteris seu verbi administris... Deinde post Domini ascensionem apostoli superiores erant reliquis verbi ministris. Et multiplicatis coetibus constituerunt apostoli ecclesiis proprios episcopos, cum ipsi omnibus adesse aut subvenire non possent. Neque ullo unquam tempore simplices presbyteri fuerunt supremi in ecclesia rectores (nisi forte alicubi, post tempora apostolica, per defectum oeconomicum particulari interdum ecclesiae contingentem). Aliter enim ecclesiae suae regimen Dominus instituit.

The series goes on :

V. Juri divino congruit, post apostolos omnium societatum communes moderatores, ut unicuique dioecesano pastorum collegio unus praesit moderator, potius quam plures.

VI. Juri divino consentaneum est, ut moderator sive praeses fratrum ordinarius non nisi propter culpam aut infirmitatem se abdicet officio illo, vel ab eo amoveatur. 


\section{Under James I and Charles I}

\section{Then come some " reducing" propositions :}

VII. Moderator fratrum debet ipse etiam censurae esse subjectus.

VIII. Debet praeesse cum mansuetudine, absque tyrannico fastu et dominatione.

IX. Juris divini est, ut moderator nihil ponderosum gerat absque consensu compresbyterorum.

X. Qui compresbyteris praeponitur, is manet adhuc de jure divino presbyter, et ad presbyteralis officii executionem tenetur.

The duties referred to are of course those of preaching the gospel and shepherding the flock.

XI. Quod presbyter compresbyterorum praeses et moderator ordinarius appellatus sit peculiariter episcopus, caeteris presbyterorum vocabulo contentis, id non est contra legem divinam factum, sed congruenter legi divinae introductum est, jure ecclesiastico, oecumenico, et apostolico, et perpetuo seculorum omnium usu irreprehensibiliter servatum. Idcirco, cum de re constet, turbas jam de hac nomenclatura ciere et tumultuari insolentissimae insaniae est.

XII. In Christum peccat, quicunque sive laicus sive clericus episcopi sui authoritatem contemnit, ejusque justis mandatis, in eis quae potestati episcopali subsunt, obedientiam obstinate denegat.

It is under this twelfth heading, oddly enough, that Forbes discusses the question whether the episcopate and presbyterate are two orders or one. He quotes first the language of the Areopagite, which makes them distinct, and then a number of schoolmen on the opposite side, and sums up thus :

Haec propterea commemoranda duxi, ut manifeste ostenderem nihil esse in tota hac controversia, quod adversetur propositionibus nostris de jure divino officii et dignitatis 
episcopalis supra simplices presbyteros. Nam de hoc non est inter eos dissensio; sed unanimi consensu omnes, non solum canonistae, sed etiam theologi, cum Magistro [Peter Lombard] et cum Dionysio agnoscunt episcopatum esse ordinem distinctum a presbyteratu, accipiendo ordinem pro officio in ecclesia divinitus instituto; et in primitiva ecclesia apostolos, jussu Christi, constituisse episcopos, et presbyteros, et diaconos, et esse hos tres distinctos ordines... . Neque nos aliud demonstratum ivimus.

The next proposition deals with the situation which confronted the writer in Scotland:

XIII. Ecclesia orthodoxam tenens fidem, si careat episcopo, sive presbyterorum ordinario praefecto dioecesano, laborat quidem defectu quodam oeconomico; at non propterea desinit esse vera ecclesia, neque excidit potestate illa ecclesiastica, quam habent aliae ecclesiae ab episcopis gubernatae. Quamvis optandum et annitendum, ut habeat episcopum.

This thesis is supported by a variety of considerations. The churches of Asia Minor, for instance, were churches without bishops, when St Paul and St Barnabas ordained them elders. This was before bishops began to exist. Joannes Major tells how Scotland itself had no bishops when it first became Christian ${ }^{1}$. The church of Rome did not cease to be a church when for nearly a year it was governed by presbyters, sede vacante, after the martyrdom of Xystus II. Then follows the statement:

1 This fiction, which long did duty for the presbyterian cause, was demolished by the learned treatise of William Lloyd, Bishop of St Asaph and finally of Worcester, An Historical Account of Church Government as it was in Great Britain and Ireland when they first received the Christian Religion, 1684 . 
Valida est ordinatio qui peragitur per presbyteros in eis ecclesiis in quibus non est episcopus, aut ubi non est orthodoxus, sed notorius haereticus et lupus: quamvis decentius fieret, si possibile, per orthodoxum episcopum et presbyteros : aut etiam per solos presbyteros, consentiente et concedente episcopo. Nam episcopo proprium de jure divino est

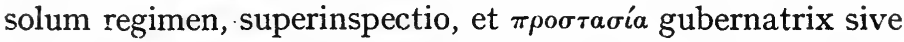
episcopalis, quam jurisdictionem vocant: reliquae autem omnes pastoralis officii partes omnibus pastoribus, tum episcopis tum presbyteris, de jure divino communes sunt: quamvis non nisi decenter et ordine exercendae, adeoque non sine episcopo aut episcopi saltem consensu, in eis locis ubi ecclesiam regit episcopus.

This statement is succeeded by several quasihistorical statements which Forbes could not have used if he had written at a later date, when they had been more sifted. It is not easy to see how he reconciled them with the belief that there was any divine right in episcopacy.

It will be convenient to pass from these authors to the group of divines who were sent by James I to take part in the synod of Dort in I6I8,- - that synod which contributed to detach De Dominis from Anglicanism, and which Crakanthorp defends as being, " in the present state of the church," a holy and lawful " national" synod, which decreed only the ancient, orthodox, scriptural faith ${ }^{1}$.

The leader of the group was George Carleton, Bishop of Chichester. Carleton was brought up in the traditions of Bernard Gilpin, whose life he wrote. He records, with evident satisfaction, how Gilpin, in 
spite of all his zeal as a reformer, shocked the selfconfident partisan who endeavoured to draw him over to the presbyterian side and the system favoured by Calvin and himself.

Mr Gilpin told him that he could not allow that an human invention should take place in the church instead of a divine institution. "And how do you think," saith the man, "that this form of discipline is an human invention?" "I am," saith Mr Gilpin, " altogether of that mind. And as many as shall diligently have turned over the writings of the ancient fathers will be of mine opinion. I suspect that form of discipline which appeareth not to have been received in any ancient church." " But yet," saith the man, "latter men do see many things which those ancient fathers saw not; and the present church seemeth better provided of many ingenious and industrious men." Mr Gilpin seemed somewhat moved at that word, and replied, "I for my part do not hold the virtues of the latter men worthy to be compared to the infirmities of the fathers ${ }^{1}$."

The main object of the synod of Dort was to compose the differences between various Calvinistic nuances and to form a solid front against the rising school of the Arminians. It was a work into which the Englishmen could throw themselves heartily, while exercising an influence that told in favour of breadth and moderation. They were completely at home among the protestant Dutchmen. But great was their indignation when they found the synod departing from its proper business to pronounce in favour of the Calvinistic parity of ministers. Bishop Carleton warmly protested, and put his protest on record :

1 Wordsworth Ecclesiastical Biography, vol. III. p. 4II. 
Touching the point of their discipline in the Low Countries, I can witness that they are weary of it, and would gladly be freed if they could. When we were to yield our consent to the Belgic Confession at Dort, I made open protestation in the synod, that whereas in the Confession there was inserted a strange conceit of the parity of ministers, to be instituted by Christ, I declared our dissent utterly in that point. I showed that by Christ a parity was never instituted in the church; that he ordained twelve apostles and also seventy disciples; that the authority of the twelve was above the other; that the church preserved this order left by our Saviour; and therefore when the extraordinary authority of the apostles ceased, yet their ordinary authority continued in bishops who succeeded them, who were by the apostles themselves left in the government of the church, to ordain ministers, and to see that they who were so ordained should preach no other doctrine; that in an inferior degree the ministers that were governed by bishops succeeded the seventy disciples; that this order hath been maintained in the church from the time of the apostles ; and herein I appealed to the judgment of antiquity, and to the judgment of any learned man now living, and craved herein to be satisfied, if any man of learning could speak to the contrary. My Lord of Salisbury is my witness, and so are all the rest of our company, who spake also in the cause. To this there was no answer made by any ; whereupon we conceived that they yielded to the truth of the protestation. And somewhat I can say of mine own knowledge, for I had conference with divers of the best learned in that synod. I told them that the cause of all their troubles was this, that they had no bishops amongst them, who by their authority might repress turbulent spirits that broached novelties. Every man had liberty to speak or write what he list, and as long as there were no ecclesiastical men in authority to repress and censure such contentious spirits, their church could never be without trouble. Their answer was, that they did much honour and reverence the 
good order and discipline of the church of England, and with all their hearts would be glad to have it established amongst them; but that could not be hoped for in their state. Their hope was, that seeing they could not do what they desired, God would be merciful to them if they did what they could. This was their answer, which I think is enough to exeuse them, that they do not openly aim at an anarchy and popular confusion. The truth is, they groan under that burden, and would be eased if they could. This is well known to the rest of my associates there ${ }^{1}$.

" My Lord of Salisbury " in this protestation was John Davenant. He was not yet bishop at the time of the synod; he was the Lady Margaret's Professor of Divinity at Cambridge. In one of his professorial lectures there he dealt with the difference between bishops and priests. The question whether they formed a single order he dismissed as a quibble :

De episcopatu et presbyteratu solummodo disputandum est. Neque hic opus erit subtiliter disquirere utrum episcopatus sit diversus ordo a presbyteratu, an alius et altior gradus in eodem ordine.... Nobis sufficit (hac' verborum velitatione seposita) si ostendamus eos qui appropriate vocantur episcopi habere dignitatem altiorem, potestatem majorem, et eminentiora officia sibi annexa quam habent alii presbyteri, idque verbo Dei minime repugnante. Sed parum est quod dicimus non repugnante: nam in verbo divino adumbratam, delineatam, et ab ipsis apostolis constabilitam fuisse hanc episcoporum supra presbyteros eminentiam facile est demonstrare.

After showing in the usual way that episcopacy is apostolic in origin, Davenant goes on :

1 Bishop Carleton's testimony concerning the presbyterian discipline in the Low Countries, and episcopal government here in England, published as a tract in 1642 . 


\section{Under James I and Charles I}

Hisce episcopis apostolorum autoritate sic stabilitis con-stat perpetua serie successores fuisse subrogatos in iisdem civitatibus....Id jam ultimo in loco dispiciendum est, quibus in rebus sita fuerit praecellens haec dignitas et potestas episcoporum, qua distinguantur ab aliis presbyteris inferioribus, idque non sua praesumptione sed ordinatione apostolica.

The distinguishing notes are three. The first is the bishop's unique authority ; the third is his jurisdiction over clergy and laity; the second is.

Jus et potestas ordinandi, quae ab ipsis apostolis ad episcopos transmissa, presbyteris autem denegata est.

This is shown by the charge to Timothy and Titus :

Cur ante appulsum Timothei non potuerunt presbyteri. Ephesini alios ordinare ? cur ante adventum Titi non licuit Cretensibus ministris idem facere? Nulla ratio hujus rei assignari potest satis idonea, nisi quod ordinandi potestas in illis solis residet, qui episcopali munere funguntur. Hieronymus (qui videtur nonnullis cum Aerio sensisse) fatetur tamen ordinationem ita propriam esse episcoporum, ut fas non sit presbyteris eam sibi usurpare.... Huic instituto apostolico semper acquievit ecclesia catholica, nec aliam ordinationem legitimam agnovit quam quae ab episcopo legitimo celebratur.

\section{Then Davenant comes to the exception :}

Sed hic obiter dubium explicemus quod ab ipsis scholasticis non est praetermissum. Quaerere enim solent, an praeter episcopum, qui ex officio ordines sacros dispensat, possit inferior episcopo eosdem dispensare in casu necessitatis. Ad quod respondemus, cum ordines sacros conferre ex institutione apostolica sit actus officii episcopalis, si presbyteri in ecclesia bene instituta id facerent, actum hunc illorum non modo illicitum esse, sed irritum et inanem. 
Hic enim valebit illud Hugonis, Quod contra institutionem celebratur, irritum reputatur. Sed in ecclesia turbata, ubi episcopi omnes in haeresin aut idololatriam inciderunt, ubi ministros orthodoxos ordinare recusarunt, ubi solos factionis et erroris sui participes sacris ordinibus dignos reputarunt, si orthodoxi presbyteri (ne pereat ecclesia) alios presbyteros cogantur ordinare, ego non ausim hujusmodi ordinationes pronuntiare irritas et inanes.... Necessitas non inscite lex temporis appellatur; et in tali casu defendit id ad quod coegit....Hac freti necessitate, si ecclesiae quaedam protestantium, quae ordinationes ab episcopis papistis expectare non poterant, consensu presbyterorum suorum presbyteros ordinarunt, non inde dignitati episcopali praejudicasse sed necessitati ecclesiae obtemperasse judicandi sunt ${ }^{1}$.

In his Exhortation to Brotherly Communion, Davenant does not even allude to differences of polity among the hindrances to communion. He assumes that communion exists between the church of England and both of the contending parties, Calvinistic and Lutheran :

I doubt not at all, but that the Saxon and Helvetian churches, and others which either consent with these or those, acknowledge themselves to have, and to desire to retain, brotherly communion with the English, Scottish, Irish, and other foreign reformed churches. Surely, as concerning us, although we consent not with them in all points and titles of controversial divinity, yet we acknowledge them brethren in Christ, and protest ourselves to have a brotherly and holy communion with them. But if they themselves be like-minded towards us, with what equity do the German churches amongst themselves deprive each other of that brotherly communion, which with foreign churches they fear not to retain ${ }^{2}$ ?

1 Determinationes quaestionum quarundam, pp. 187 foll. (I639).

2 Letter to John Dury in Exhortation to Brotherly Communion, p. 33 (I64I). 
With regard to the varying confessions and articles of different churches:

It is lawful and useful for every particular church to exercise that jurisdiction over their own people, which in no case they ought or can usurp over the subjects of another church. For if their own oppose the received doctrine of their church, established by public consent, they may (both for the errors they scatter, and for the disturbance they cause in the church) put them aside from the communion of their church so long till they leave off to infect others and trouble the church with their errors. But as soon as they repent of their errors, they are to be received again into the bosom of their mother. Thus may they deal with their own. But when they are to meddle with churches not at all subordinate unto them, they may hold divine concord and keep God's peace with those which think and teach otherwise than themselves, as we may see it in Cyprian ${ }^{1}$.

The third of the English divines at Dort was a more eminent man than either Carleton or Davenant. It was Joseph Hall, then Dean of Worcester. In I635, as Bishop of Exeter, he sent to King Charles Certain Irrefragable Propositions worthy of serious Consideration, which were disseminated as a leaflet. Two of these propositions were

I. No man living, no history, can show any well-allowed and settled national church in the whole Christian world, that hath been governed otherwise than by bishops, in a meet and moderate imparity, ever since the times of Christ and his apostles, until this present age.

2. No man living, no record of history, can show any lay-presbyter, that ever was in the whole Christian church, until this present age ${ }^{2}$.

${ }^{1}$ Exhortation, p. 42.

${ }^{2}$ Works (ed. 1837), vol. x. p. 139. 
Two years later, in I637, at the entreaty, as it seems, of Archbishop Laud, the bishop published his great contribution to the question in the book called Episcopacy by Divine Right. His " expostulatory entrance into the question" was occasioned by the action of Graham, Bishop of Orkney, who had renounced his episcopal function to the Scottish Assembly and craved pardon for having accepted it ${ }^{1}$.

Brother that was, the poet-bishop exclaims, whoever you be, I must have leave awhile to contest seriously with you. The act was yours; the concernment, the whole church's. You could not think so foul a deed could escape unquestioned. The world never heard of such a penance: you cannot blame us, if we receive it both with wonder and expostulation and tell you, it had been much better to have been unborn, than to live to give so heinous a scandal to God's church, and so deep a wound to his holy truth and ordinance. If Tweed, that runs between us, were an ocean, it could not either drown or wash off our interest or your offence. However you may be applauded for the time by some ignorant and partial abettors, wiser posterity shall blush for you, and censure you too justly for some kind of apostacy ${ }^{2}$.

Hall points out the difference between the conditions under which the foreign and the Scotch reformation began, as regards the bishops, and those under which the unhappy Graham acted.

Acts done out of any extremity can be no precedents for voluntary and deliberate resolutions.... They were forced to discard the office, as well as the men: but yet the office because of the men; as popish, not as bishops: and

1 See Grub's Eccl. History of Scotland, vol. IIr. p. 62.

${ }^{2}$ Hall's Works, vol. x. p. I 45. 


\section{Under James I and Charles I II 3}

to put themselves, for the present, into such a form of government, at a venture, as under which they might be sure without violent interruption to sow the seeds of the... Gospel.... This was their case; but what is this to yours? Your church was happily gone out of Babylon. Your and our...sovereign sincerely professeth...the blessedly-reformed religion: his bishops preach for it, write for it, and profess themselves ready, after the example of their predecessors, to bleed for it. Your and our late learned and pious sovereign, of blessed memory, with the general votes of a lawful assembly, reinforced that order of episcopacy, which had been, as I take it, but about seventeen years discontinued ${ }^{1}$.

The first part of Hall's work consists in laying out the postulata or grounds which he is prepared to maintain. They are as follows :

I. That government whose foundation is laid by Christ, and whose fabric is raised by the apostles, is of divine institution.

2. The practice and recommendation of the apostles is sufficient warrant for an apostolical institution.

3. The forms ordained for the church's administration by the apostles were for universal and perpetual use.

4. The universal practice of the church immediately succeeding the apostolic times is a sure commentary upon the practice of the apostles, and our best direction.

5. The primitive saints and fathers neither would nor durst set up another form of government, different from that they received of the apostles.

6. If the next successors would have innovated the form of government, yet they could not in so short a space: have diffused it through the whole Christian world.

7. The ancientest histories of the church and writings: of the first fathers are rather to be believed in the report of the primitive state of the church than the latest authors.

${ }^{1}$ Works, vol. x. pp. 152 foll.

M. 


\section{4 Under James I and Charles I}

8. Those whom the ancient church of God and all the holy fathers of the church since have condemned for heretics are no fit guides for us to follow in that their judgment of the government, for which they were so condemned.

The next six postulata are destructive of the new platform : it is only necessary here to mention

I5. To depart from the judgment and practice of the universal church of Christ ever since the apostles' times, and to betake ourselves to a new invention, cannot but be, besides the danger, vehemently scandalous.

The second part of the book is occupied in the proofs of these postulata. At the outset, Hall gives a definition of the episcopacy which he intends to prove.

Episcopacy is no other than a holy order of churchgovernors, appointed for the administration of the church, or more fully thus: Episcopacy is an eminent order of sacred function, appointed by the Holy Ghost in the evangelical church for the governing and overseeing thereof; and for that purpose, besides the administration of the word and sacraments, endued with power of imposition of hands and perpetuity of jurisdiction ${ }^{1}$.

Give me, he says, such a pastor as shall be ordained a Perpetual Moderator in church affairs, in a fixed imparity, exercising spiritual jurisdiction out of his own peculiarly demandated authority: this is the bishop whom we contend for, and whom they oppose.... The only thing that displeaseth in episcopacy is their majority above presbyters, which it is pretended should be only a priority in order, not a superiority of degree, and their power of jurisdiction over presbyters. For yield these by a due ordination to a prime pastor for a constant continuance, you make him a bishop ; deny these to a bishop, you make him no other than a plain presbyter ${ }^{2}$.

1 Works, vol. x. p. 183.

${ }^{2}$ Ibid. pp. 185 foll. 


\section{Under James I and Charles I I I 5}

On the question whether the episcopate is a separate order or a degree within the order, Bishop Hall is content to follow Andrewes:

For ourselves, taking order in that sense in which our oracle of learning, Bishop Andrewes, cites it out of the School, qua potestas est ad actum specialem, there can be no reason to deny episcopacy to be a distinct order, since the greatest detractors from it have granted the power of ordination of priests and deacons, and of imposition of hands for confirmation, to bishops only. They are Chamier's own words,... . "I cannot deny that a bishop," as such, " receiveth a new power and jurisdiction." Moreover, in the church of England, every bishop receives a new ordination, by way of eminence commonly called his consecration, which cannot be a void act, I trow, and must needs give more than a degree. And why should that great and sacred council [of Chalcedon] define it to be no less than sacrilege to put down a bishop into the place of a presbyter, if it were only an abatement of a degree ? ...I demand, what is it that is stood upon, but these two particulars, the especial power of ordination, and power of the ruling and censuring of presbyters? and if these two be not clear in the charge of the apostle to those two bishops [Timothy and Titus], one of Crete, the other of Ephesus, I shall yield the cause, and confess to want my senses ${ }^{1}$.

Hall passes from scripture to history:

Did not the holy scriptures yield unto us these firm grounds, whereon to build our episcopacy, in vain should we plead the tradition and practice of the church ever since, forasmuch as we have to deal with those who are equally disaffected to the name of a bishop and to tradition, and are so forestalled with their own prejudice that they are carried, where scripture is silent, to an unjust jealousy against the universal practice of the whole church of God upon earth.

1 Works, vol. x. pp. 192 foll. 
But now, when Christ and his apostles give us the text, well may the apostolical and universal church give us the commentary. And that, let me boldly say, is so clear for us, that if our opposites dare stand to this trial, the day is ours ${ }^{1}$.

It was Hall's good fortune to be the first to use for this purpose " that noble and holy epistle" of Clement which had lately become known by Cyril Lucar's gift to King Charles of the Alexandrine manuscript containing it. He was able also to use the epistles of Ignatius, though as yet they were only published in an incomplete and ill-assured form. He used both with great effect.

For me, let my soul go with his [Ignatius's]: let his faith be mine: and let me rather trust one Ignatius, than ten thousand Cartwrights, Parkers, Ameses, or any other their ignorant and malcontented followers ${ }^{2}$.

\section{Coming to the "power of ordination only in bishops," Hall says :}

Even those testimonies which are wont to be alleged against us, do directly plead for us. Jerome himself can say, excepta ordinatione; and Chrysostom, who is cited for

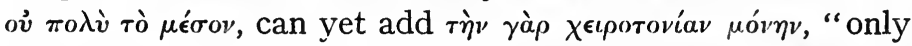
in laying on of hands bishops go beyond them." Neither is this any slight difference, or despicable privilege, but such as implies a manifest superiority.... That presbyter had been a monster among Christians, that would have dared to usurp [the privilege of laying on of hands] ; and the church of those first ages observed it so curiously, that besides those strict laws which they made for the prevention of any such insolence,... they have left unto us memorable records of their severe proceedings against such presumptions ${ }^{3}$.

1 Works, vol. x. p. 203.

2 Ibid. p. 219.

3 Ibid. p. 225. 
If either the apostles then, or the bishops since, have had other hands laid upon the ordained together with theirs, as the rule and practice of the church of England is, yet fain would I see where ever it can be read that presbyters, without a bishop, in a regular course imposed hands for ordination ${ }^{1}$.

Hall concludes this constructive section of his work with the assertion that "the government by bishops" is " both universal and unalterable."

Yield it to be so ancient as the apostles themselves; yet if it be arbitrary (i.e. alterable at will), whether for time or place, what have we gained? Surely, as God is but one, and ever himself, so would he have his church.... Plainly though there may be varieties of circumstantial fashions in particular churches, yet the substance of the government is and must be ever the same... . The Holy Ghost led them unto it; and therefore we, unless we will oppose the ordinance of the Holy Ghost, must not detrect to continue it... For the main substance, it is now utterly indispensable, and must so continue to the world's end. Indispensable by any voluntary act: what inevitable necessity may do in such a case, we now dispute not : necessity hath dispensed with some immediately divine laws. Where then that may be justly pleaded, we shall not be wanting, both in our pity and in our prayers ${ }^{2}$.

It is known that Hall's work was pointed here and there before publication by the hands of Laud and his immediate circle. There is, however, no reason to doubt that Hall accepted the suggestions ex animo, and that the book as it now stands represents the convictions of its celebrated author. It was far the best book on the subject that had yet

1 Works, vol. x. p. 227.

2 Ibid. pp. 242, 245. 
appeared. Lucid and well-arranged, learned without being pedantic, pungent and yet kindly and charitable, it is the work of a deeply thoughtful Christian, a peacemaker, a poet, and a scholar ${ }^{1}$.

Three other books must be considered as forming a constellation with Hall's. Of these three the first was Usher's.

The great name of Archbishop Usher is enough to give importance to any tract which bears it, however inconsiderable its bulk may be. In the year I64I Usher wrote a paper on the Original of Bishops and Metropolitans briefly laid down. He did so at the request of Bishop Hall, who said in a letter to him :

I must crave leave... to importune that your Grace would be pleased to bestow one sheet of paper upon these distracted times, in the subject of episcopacy, showing the apostolical original of it, and the grounds of it from scripture, and the immediately succeeding antiquity. Every line of it coming from your Grace's hand would be super rotas suas... . Think that I stand before you like the man of Macedon, and that you hear me say, Come and help us ${ }^{2}$.

In this tract Usher adopts the opinion that the ground of episcopacy is derived partly from the pattern prescribed by God in the Old Testament,

1 It is interesting to observe that the other Anglican representative at Dort, Samuel Ward, who was not a writer, was evidently of the same way of thinking. Bramhall records that, when he was a young student in theology, Ward declared to him " that it was impossible that the present controversies of the church should be rightly determined or reconciled without a deep insight into the doctrine of the primitive fathers, and a competent skill in school theology" (Bramhall's Works, I844, vol. III. p. 568).

${ }^{2}$ Elrington's Life of Usher (vol. I. of Works, 1847, p. 225). 


\section{Under James I and Charles I}

partly from the imitation of it brought in by the apostles, and confirmed by Christ himself in the time of the New. It was the fulfilment of the prophecy that God would take of the Gentiles "for priests, and for levites," where differences of order are implied. The approval of Christ is shown by his messages to the angels of the churches of Asia.

That there was then a standing president over the rest of the pastors of Ephesus, and he the very same... with him whom afterward the fathers called bishop, may further be made manifest, not only by the succession of the first bishops of that church, but also by the clear testimony of Ignatius ; who within no greater compass of time than twelve years afterwards distinguisheth the singular and constant president thereof from the rest of the number of the presbyters, by appropriating the name of bishop unto him ${ }^{1}$.

Briefly, but forcibly, Usher draws out the testimony of the Apostolic Fathers, and shows the value attached by the earliest catholic writers to the successions of bishops, bringing out particularly the activity of St John in establishing episcopacy. Then the great scholar goes on to discuss the seven churches, and to indicate that each of them was in fact a metropolitan see, and so, somewhat like Overall, traces the beginnings of provincial jurisdictions back to the earliest days of the church.

A second tract from Usher's pen, published in the same year, reinforced "the judgment of Dr Rainoldes touching the Original of Episcopacy." It went, though more slightly, over the same ground, and ended with the words

1 Works, vol. viI. p. 47. 
And thus much may suffice for the deduction of episcopacy from the apostolical times.

Into the further questions, which were occupying other divines, concerning the specific functions of a bishop compared with those of a presbyter, Usher did not think it necessary in these papers to enter. But the judgment of Usher was not concealed. Bernard, his first biographer, says that Usher, while inclining to the Hieronymian theory of two degrees within a single order, thought nevertheless

that the degree which the bishop hath above a presbyter is not to be understood as an arbitrary matter at the pleasure of men, but that he held it to be of apostolical institution,

and that the gradus was derived from the old and New Testament pattern above mentioned.

A far more famous paper came from the hand of the archbishop, though it was not published with his authority, in the same year. It was his Reduction of Episcopacy unto the form of Synodical Government received in the ancient Church ${ }^{1}$.

How far the form of the Reduction published by Bernard in 1658 really represented the deliberate mind of Usher is a matter of controversy. Elrington says:

It would seem that, by taking away from bishops all power of order and jurisdiction, there was left to them but the empty title of superintendent or president of the ecclesiastical synod. If the primate ever did make such a concession, it must have arisen from the effect produced upon his gentle nature by the violent commotions which he

'See Works, vol. xir. p. 527. 


\section{Under James I and Charles I}

witnessed. He must have considered resistance impossible, and that the preservation of any shadow of our ecclesiastical constitution was better than the risk of its total destruction before the reforming rage of the Lower House of Parliament ${ }^{1}$.

Two things, however, are certain. However severely the episcopal monarchy was limited in the Reduction, however little the bishop was allowed to do without his presbyters and all the tedious apparatus of synods, the Reduction contains no suggestion that the bishop should not be specially consecrated to his office, and no suggestion that the presbytery might on occasion ordain without the bishop. There is no ground for Elrington's statement that the Reduction took away from the bishop all power of order. On these two points it may be seen that the learned reducer could admit of no compromise.

Elrington appears to be wholly justified in describing as " incredible " a story related by Baxter, to the effect that Usher told Baxter that in antiquity presbyters ordained freely. His views on presbyterian ordination are plainly shown by an unimpeachable witness, who would have been glad to find the archbishop more sympathetic towards it.

Elrington says :

Dr Bernard states that a report was circulated of the Primate having given an unfavourable judgment of the ordination beyond the sea, founded on the following statement : " $\mathrm{Mr}$ — asked the Archbishop of Armagh on occasion of an ordination, what he thought of them that were ordained by presbyters; he said he judged their ordination to be null

1 Life (ut supra), p. 209. 
and looked on them as laymen. He asked him what he conceived of the churches beyond the sea. The bishop answered he had charitable thoughts of them in France: but as for Holland he questioned if there was a church among them or not; or words to that purpose : this Drconfidently reports." The paper containing this statement was forwarded to the Primate by Dr Bernard, who gives the following extracts from his Grace's answer: it is unfortunate and rather extraordinary that he did not give the whole letter: "Touching $\mathrm{Mr} \longrightarrow$ I cannot call to mind that he ever proposed to me the question in your letter enclosed, neither do I know the Dr who hath spread the report; but for the matter itself, I have ever declared my opinion to be that Episcopus et Presbyter gradu tantum differunt, non ordine, and consequently that in places where bishops cannot be had, the ordination of presbyters standeth valid: yet on the other side holding as I do, that a bishop hath a superiority in degree over a presbyter, you may easily judge that the ordination made by such presbyters as have severed themselves from those bishops unto whom they had sworn canonical obedience cannot possibly by me be excused from being schismatical : and howsoever I must needs think that the churches which have no bishops are thereby become very much defective in their government, and that the churches in France, who, living under a popish power, cannot do what they would, are more excusable in this defect than the Low Countries, that live under a free state, yet for testifying my communion with these churches (which I do love and honour as true members of the Church Universal) I do profess that with like affection I should receive the blessed sacrament at the hands of the Dutch ministers, if I were in Holland, as I should do at the hands of the French ministers if I were in Charenton ${ }^{1}$."

For this opinion of the gradus tantum, among

1 Elrington's Life of Usher, p. 258. Cp. Elrington's remarks on p. 256 . 
- other points, Usher was assailed by Laud's chaplain and biographer, Heylin, in a tract called Respondet Petrus, and defended by his own chaplain and biographer Parr. Parr says that he found almost the same words written in a private note-book of Usher's and dated not long before his death, with this clause added :

For the agreement or disagreement in radical and fundamental doctrines, not the consonancy or dissonancy in the particular points of ecclesiastical government, is with me, and I hope with every man that mindeth peace, the rule of adhering to, or receding from the communion of any church $^{1}$.

The third star in this constellation is Jeremy Taylor's Episcopacy Asserted, or, to give it its full title, Of the sacred order and offices of Episcopacy, by divine institution, apostolical tradition, and catholic practice, first published in 1642 .

It starts with the assertion:

The catholic practice of Christendom for fifteen hundred years is so insupportable a prejudice against the enemies of episcopacy, that they must bring admirable evidence of scripture, or a clear revelation proved by miracles, or a contrary undoubted tradition apostolical for themselves, or else hope for no belief against the prescribed possession of so many ages ${ }^{2}$.

Taylor lays it down that Christ instituted a government in his church, committed to his apostles with power of transmission to successors :

1 Parr's Life of Usher, Appendix, p. 6.

${ }^{2}$ Works (ed. 1849), vol. v. pp. I5 foll. The word "prescribed" is, of course, an allusion to Tertullian's famous argument de praescriptione. 
That Christ did in this place erect a jurisdiction and establish a government, besides the evidence of fact, is generally asserted by primitive exposition of the fathers, affirming that to St Peter the keys were given, that to the church of all ages a power of binding and loosing might be communicated... This government was by immediate substitution delegated to the apostles by Christ himself, in traditione clavium, in spiratione Spiritus, in missione in Pentecoste... This power so delegated was not to expire with their persons; for when the great Shepherd had reduced his wandering sheep into a fold, he would not leave them without guides to govern them so long as the wolf might possibly prey upon them, and that is, till the last separation of the sheep from the goats.... And therefore, that the apostolate might be perpetual and successive, Christ gave them a power of ordination, that by imposing hands on others they might impart that power which they received from Christ.... Of necessity a succession must be constituted in the ordinary office of apostolate. Now what is this ordinary office?... In clear evidence of sense these offices and powers are preaching, baptizing, consecrating, ordaining and governing. For these were necessary for the perpetuating of a church, unless men could be Christians that were never christened, nourished up to life without the eucharist, become priests without calling of God and ordination, have their sins pardoned without absolution, be members and parts and sons of a church, whereof there is no coadunation, no authority, no governor. These the apostles had without all question; and whatsoever they had, they had from Christ, and these were eternally necessary; these then were the offices of that apostolate which Christ promised to assist for ever, and this is that which we now call the order and office of episcopacy ${ }^{\mathbf{1}}$.

Taylor, like others, argues from the difference between the twelve and the seventy:

It is clear in scripture that the apostles did some acts 1 Works, vol. v. pp. 17, 19, 20. 


\section{Under James I and Charles I}

of ministry which were done for ever in the church, and therefore to be committed to their successors, which acts the seventy disciples or presbyters could not do.... The apostles imposed hands in ordinations, which the seventy-two did not.... Imposition of hands is a duty and office necessary for the perpetuating of a church, ne gens sit unius aetatis, "lest it expire in one age." This power of imposition of hands for ordination was fixed upon the apostles and apostolic men, and not communicated to the seventy-two disciples or presbyters; for the apostles and apostolic men did so de facto, and were commanded to do so, and the seventy-two never did so. Therefore this office and ministry of the apostolate is distinct and superior to that of presbyters; and this distinction must be so continued to all ages of the church ; for the thing was not temporary, but productive of issue and succession, and therefore as perpetual as the clergy, as the church itself ${ }^{1}$.

The sum of all is this: that Christ did institute apostles, and presbyters, or seventy-two disciples. To the apostles he gave a plenitude of power, for the whole commission was given to them in as great and comprehensive clauses as were imaginable; for by virtue of it they received a power of giving the Holy Ghost in confirmation, and of giving his grace in the collation of holy orders, a power of jurisdiction and authority to govern the church ; and this power was not temporary, but successive and perpetual, and was intended as an ordinary office in the church, so that the successors of the apostles had the same right and institution that the apostles themselves had.... But to the seventy-two Christ gave no commission but of preaching, which was a very limited commission... . This I shall afterwards confirm by the practice of the catholic church, and so vindicate the practices of the present church from the common prejudices that disturb us; for by this account episcopacy is not only a divine institution, but the only order that derives immediately from Christ².

I Works, vol. v. pp. 25, 27.

${ }^{2}$ Ibid. p. $3^{8}$. 
With sufficient fulness Taylor works out the proof that in pursuance of the divine institution the apostles ordained bishops in various churches, and concludes this part of his argument thus :

The sum is this. Although [i.e. even if] we had not proved the immediate divine institution of episcopal power over presbyters and the whole flock, yet episcopacy is not less than an apostolical ordinance, and delivered to us by the same authority that the observation of the Lord's day is. For that in the New Testament we have no precept, and nothing but the example of the primitive disciples meeting in their synaxes upon that day ;... but yet (however that at Geneva they were once in meditation to have changed it into a Thursday meeting, to have shown their Christian liberty) we should think strangely of those men that called the Sunday festival less than an apostolical ordinance and necessary now to be kept holy with such observances as the church hath appointed.... Divers others of greater consequence, which I dare not specify for fear of being misunderstood, rely but upon equal faith with this of episcopacy (though I should waive all the arguments for immediate divine ordinance) ; and therefore it is but reasonable it should be ranked among the credenda of Christianity, which the church hath entertained upon the confidence of that which we call "the faith of a Christian," whose Master is truth itself ${ }^{1}$.

Taylor proves that the episcopate was a distinct order from the presbyterate by three arguments. First the presbyterate was a step to it, as the diaconate was to the presbyterate. Secondly, the promotion was effected by a new ordination. Thirdly, the presbyters never joined in laying hands upon those who were consecrated to this higher office.

1 Works, vol. v. pp. 68, 69. 


\section{Under James I and Charles I}

These premises, he says, do most certainly infer a real difference between episcopacy and the presbyterate; but whether or no they infer a difference of order or only of degree, or whether degree and order be all one or no, is of great consideration in the present and in relation to many other questions ${ }^{1}$.

He argues therefore that in ancient times ordo and gradus, and their Greek equivalents, were used promiscuously. In all orders, he says, there is the impress of a distinct character; that is, the person is qualified with a new capacity to do certain offices which before his ordination he had no power to do. As there is a fresh act of ordination when a presbyter becomes a bishop, it is clear that a fresh character is impressed,- - that is that the person consecrated passes into a new order. Taylor rejects and demolishes the contrary opinion, as " an innovation, of the production of some in the church of Rome, without all reason and against all antiquity." Very briefly, and in this connexion, Taylor argues against the view that a bishop may be consecrated per saltum from the laity ${ }^{2}$.

To clear the distinction of order, he proceeds, it is evident in antiquity that bishops had a power of imposing hands for collating of orders, which presbyters have not ${ }^{3}$.

In proof of this position he examines the canons laid down for regulation of chorepiscopi, and various instances of alleged ordination by presbyters, which were judged to be null,--and not null in the sense that they were uncanonical, though possibly valid.
1 Works, vol. v. p. 105.
${ }^{2}$ Ibid. p. Iog.
${ }^{3}$ Ibid.p. I 10. 
If to this be added that in antiquity it was dogmatically resolved that by nature and institution of the order of bishops ordination was appropriate to them, then it will also from hence be evident that the nullity of ordination without a bishop is not dependent upon positive constitution, but on the exigence of the institution. Now, that the power of ordination was only in the bishop, even they who to advance the presbyters were willing enough to speak less for episcopacy, give testimony, making this the proper distinctive cognizance of a bishop from a presbyter, that the bishop hath power of ordination, the presbyter hath not.... Ordination is the proper and peculiar function of a bishop, and therefore not given him by positive constitution of the canon ${ }^{1}$.

We come at length to the crucial question of churches that have no bishops. Taylor's treatment of it is most suggestive :

But then, are all ordinations invalid which are done by mere presbyters without a bishop? What think we of the reformed churches?

I. For my part I know not what to think ; the question hath been so often asked with so much violence and prejudice, and we are so bound by public interest to approve all that they do, that we have disabled ourselves to justify our own. For we were glad at first of abettors against the errors of the Roman church; we found these men zealous in it ; we thanked God for it, as we had cause ; and we were willing to make them recompense by endeavouring to justify their ordinations, not thinking what would follow upon ourselves. But now it is come to that issue that our own episcopacy is thought not necessary, because we did not condemn the ordinations of their presbytery.

2. Why is not the question rather what we think of the primitive church than what we think of the reformed 


\section{Under James I and Charles I}

churches? Did the primitive councils and fathers do well in condemning the ordinations made by mere presbyters? If they did well, what was a virtue in them is no $\sin$ in us ; if they did ill, from what principle shall we judge of the right of ordinations? Since there is no example in scripture of any ordination made but by apostles and bishops.... So that whence will men take their estimate for the rites of ordinations? From scripture? That gives it always to apostles and bishops, as I have proved; and that a priest did ever impose hands for ordination can never be shown from thence. From whence then? From antiquity? That was so far from licensing ordinations made by presbyters alone, that presbyters in the primitive church did never join with bishops in collating holy orders of presbyter and deacon till the fourth council of Carthage,--much less do it alone, rightly and with effect. So that as in scripture there is nothing for presbyters ordaining, so in antiquity there is much against it ; and either in this particular we must have strange thoughts of scripture and antiquity, or not so fair interpretation of the ordinations of reformed presbyteries. But for my part I had rather speak a truth in sincerity, than err with a glorious correspondence [i.e. with an ostentatious agreement].

Taylor examines the argument from necessity:

But will not necessity excuse them who could not have orders from orthodox bishops? Shall we either sin against our consciences by subscribing to heretical and false resolutions in materia fidei, or else lose the being of a church for want of episcopal ordinations? Indeed if the case were just this, it was very hard with good people of the transmarine churches; but I have here two things to consider.

First, I am very willing to believe that they would not have done anything either of error or suspicion but in cases of necessity. But then I consider that M. Du Plessis, a man of honour and great learning, does attest that at the first reformation there were many archbishops and cardinals.

M. 
in Germany, England, France, and Italy, that joined in the reformation, whom they might, but did not, employ in their ordinations; and what necessity then can be pretended in this case I would fain learn, that I might make their defence. But, which is of more and deeper consideration... it is their constant and resolved practice, at least in France, that if any returns to them, they will reordain him by their presbyters, though he had before episcopal ordination, as both their friends and their enemies bear witness.

Secondly I consider that necessity may excuse a personal delinquency, but I never heard that necessity did build a church. Indeed, no man is forced for his own particular to commit a sin, for if it be absolutely a case of necessity, the action ceaseth to be a sin. But indeed if God means to build a church in any place, he will do it by means proportionable to that end; that is, by putting them into a possibility of doing and acquiring those things which himself hath required of necessity to the constitution of a church. So that supposing that ordination by a bishop is necessary for the vocation of priests and deacons (as I have proved it is), and therefore for the founding and perpetuating of a church, either God hath given to all churches opportunity and possibility of such ordinations, and then necessity of the contrary is but pretence and mockery, or if he hath not given such possibility, then there is no church there to be either built or continued, but the candlestick is presently removed.

Taylor gives some historical illustrations, and continues :

Thus the case is evident, that the want of a bishop will not excuse us from our endeavours of acquiring one.... And therefore if it happens that those bishops which are of ordinary ministration amongst us prove heretical, still God's church is catholic, and though with trouble, yet orthodox bishops might be acquired.... [A certain] Moses refused to be ordained by him that was an Arian. So did the reformed 


\section{Under James I and Charles I}

churches refuse ordinations by the bishops of the Roman communion. But what then might they have done ?... Those good people might have had order from the bishops of England, or the Lutheran churches, if at least they thought our churches catholic and Christian.

\section{Then Taylor says in a more yielding strain :}

But shall we then condemn those few of the reformed churches whose ordinations always have been without bishops? No indeed, that must not be ; they stand or fall to their own master. And though I cannot justify their ordinations, yet what degree their necessity is of, what their desire of episcopal ordinations may do for their personal excuse, and how far a good life and a catholic belief may lead a man in the way to heaven, although the forms of external communion be not observed, I cannot determine. For aught I know, their condition is the same with that of the church of Pergamus, "I know thy works, and where thou dwellest, even where Satan's seat is ; and thou holdest fast my faith, and hast not denied my name." Nihilo minus habeo adversus te pauca, some few things I have against thee ; and yet, of them, the want of canonical ordinations is a defect which I trust themselves desire to be remedied; but if it cannot be done, their sin is indeed the less, but their misery the greater....

But this I would not have declared so freely, had not the necessity of our own churches required it, and that the first pretence of the legality and validity of their ordinations [had] been buoyed up to the height of an absolute necessity ${ }^{\mathbf{1}}$; for else why shall it be called tyranny in us to call on them to conform to us and to the practice of the catholic church, and yet in them be called a good and a holy zeal to exact our conformity to them? But I hope it will so happen to us that it will be verified here what was once said of the

1 That is, the first claim, that their orders were valid, had been exchanged for the assertion that the presbyterian form was everywhere necessary. 
catholics under the fury of Justina, sed tanta fuit perseverantia fidelium populorum ut animas prius amittere quam episcopum mallent;-if it were put to our choice, rather to die... than lose the sacred order and offices of episcopacy, without which no priest, no ordination, no consecration of the sacrament, no absolution, no rite or sacrament. legitimately can be performed in order to eternity ${ }^{\mathbf{1}}$.

From this guarded concession Taylor recurs to his main thesis, derived from patristic history:

The sum is this. If the canons and sanctions apostolical ; if the decrees of eight famous councils in Christendom, of Ancyra, of Antioch, of Sardis, of Alexandria, two of Constantinople, the Arausican Council, and that of Hispalis; if the constant successive acts of the famous martyr-bishops of Rome making ordinations [i.e. regulations]; if the testimony of the whole pontifical book; if the dogmatical resolution of so many fathers, St Denys, St Cornelius, St Athanasius, St Jerome, St Chrysostom, St Epiphanius, St Austin, and divers others, all appropriating ordinations to the bishop's hand ; if the constant voice of Christendom declaring ordinations made by presbyters to be null and void in the nature of the thing ; and never any act of ordination by a non-bishop approved by any council, decretal, or single suffrage of any famous man in Christendom ; if that ordinations of bishops were always made, and they ever done by bishops; and no pretence of priests joining with them in their consecrations; and after all this it was declared heresy to communicate the power of giving orders to presbyters, either alone or in conjunction with bishops, as it was in the case of Aerius; if all this-that is, if whatsoever can be imagined, be sufficient to make faith in this particular : then it is evident that the power and order of bishops is greater than the power and order of presbyters, to wit, in this great particular of ordination, and that by this loud voice and united vote of Christendom ${ }^{2}$.

I Works, vol. v. pp. I18-122.

2 Ibid. p. 122. 
In his Episcopacy Asserted Taylor did not directly discuss the question of inter-communion with the foreign churches which were in his eyes so gravely defective. A few years later, in I647, he touches upon it at the end of his great Liberty of Prophesying. There he distinguishes between the duty of particular churches and the duty of individual Christians in this matter :

As for particular churches, they are bound to allow communion to all those that profess the same faith upon which the apostles did give communion... . To make the way to heaven straiter than God made it, or to deny to communicate with those with whom God will vouchsafe to be united, and to refuse our charity to those who have the same faith, because they have not all our opinions, and believe not everything necessary which we over-value, is impious and schismatical ; it infers tyranny on one part, and persuades and tempts to uncharitableness and animosities on both.

This is his view of the duty of church to church : his view of the duty of the individual believer is as follows :

As for the duty of particular men in the question of communicating with churches of different persuasions [he means, e.g. Calvinists, Lutherans, Greek Orthodox], it is to be regulated according to the laws of those churches. For if they require no impiety or anything unlawful as the condition of their communion, then they communicate with them as they are servants of Christ, as disciples of his doctrine and subjects to his laws, and the particular distinguishing doctrine of their sect [the word does not mean to Taylor what it means to us] hath no influence or communication with him who from another sect is willing to communicate with all the servants of their common Lord.... But this thing will scarce be reduced to practice; for few churches that have framed 


\section{I34 Under James I and Charles I}

bodies of confession and articles will endure any person that is not of the same confession; which is a plain demonstration that such bodies of confession and articles do much hurt, by becoming instruments of separating and dividing communions, and making unnecessary or uncertain propositions a certain means of schism and disunion ${ }^{1}$.

These are far-reaching statements, and might lead to consequences which perhaps Taylor himself did not altogether intend ; but their first aim and object was, in accordance with the circumstances in which they were written, to remove the narrow spirit, against which John Dury was labouring at the time, which made the Calvinistic churches refuse communion to the Lutherans, or which here in England made the Independents refuse communion to the Presbyterians.

The fourth and last of this important group of essays on episcopacy was Hammond's Dissertationes quatuor. The book was published in I65I, when episcopacy appeared to be almost extinct in England. Its object was to confute the attacks recently made upon the unpopular system by Saumaise and Blondel in France, which were assumed on the continent to have put the matter beyond the reach of further dispute. In I654 a Vindication, in English, followed, to meet the criticisms of "the London ministers." Not without reason Sage, in the vindication of his own Principles of the Cyprianic Age, describes Hammond as " a very great man, an antiquary very accurate (much more accurate than Dr Taylor), an advocate for prelacy beyond the ordinary size, both

1 Works, vol. v. pp. 6or foll. 
for industry and comprehension, and one whose writings on this controversy have made him very famous ${ }^{1}$." The Dissertationes, it must be confessed, are very tedious reading, especially when compared with the charms of Jeremy Taylor and Joseph Hall. The Latin is ungraceful, and Greek words are inserted into it with irritating frequency. Nevertheless the book was the most solid contribution to the early history of the subject which had yet appeared.

The prefatory dissertation (for there are in fact five) is on Antichrist. It seems to be beginning rather far off, but the presbyterian party held that the obnoxious institution was due to that " mystery of iniquity" which St Paul discerned as already at work when he wrote to the Thessalonians. Antichrist was to them much what "Hellenism" is to many a modern German Forscher. Hammond's contention is that the Antichrist was the Gnostic movement; but he closes with his antagonists on the dilemma,-which is independent of his particular contention :

Si episcopalis dignitatis semina apostolorum aetate in ecclesia sata reperiantur, tunc aut $\mathrm{ab}$ apostolis rejiciebantur, aut non. Si rejiciebantur, tunc illud aut scriptis ipsorum, aut áypá $\phi \omega s$ factum. Si scriptis, monstrentur in epistolis apostolorum verba aut in actis decreta quibus illud factum

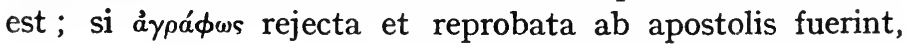
...indicentur demum capsulae quibus haec...damnatae

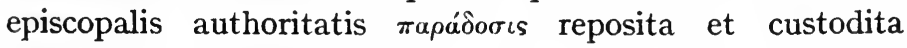
incolumis ad nos pervenerit.... Sin vero haec tam alto mane sparsa semina nulla unquam aut scripta aut non

1 Vindication (170I), p. 168. 


\section{Under James I and Charles I}

scripta apostolorum censura feriebantur, quis, quaeso, nos judices constituit, ut post universalem per tot secula in ecclesia hujus ordinis receptionem nobis tandem jubentibus damnetur ${ }^{1}$ ?

This argument is followed by another: Walo (i.e. Saumaise) and Blondel put the rise of episcopacy about a hundred years after the ascension of Christ:

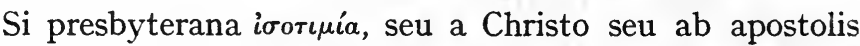
in ecclesia stabilita, sic apostolorum aevo per totam ubique ecclesiam propagata sit ut episcopalis apex toto hoc centum annorum spatio contra mutire aut hiscere ausus non sit, tunc certe fieri non potuit, ut... ab universa proxime succedentis saeculi ecclesia in aliam diversam, et plane adversam seu contrariam, immutaretur, et nulla interea aut synodo aut concilio aut conventu interveniente (cujus ope tot per orbem terrarum dissitae ecclesiae in idem sacrilegium conspirare possent), nullis epistolis canonicis (quibus consilia sua sibi invicem communicarent) tantae mutationi obstetricantibus, a Christiana in antichristianam, a genuina in meretriciam, a divina demum in diabolicam formam degeneraret.

What confidence could we have in the faithfulness of the early church about any matter if it were so unfaithful in this?

Unicum addo; si de universa Christi familia, oeconomis fidelissimis vixdum e foribus egressis, sic pronuntiandum sit;

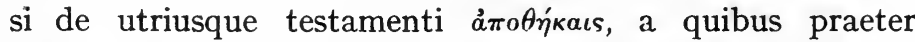

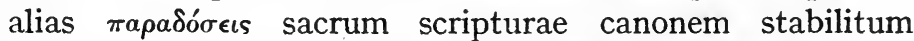
et conservatum nos accepisse agnoscimus, haec et talia censenda sunt; habebunt adversarii nostri unde de hierarchicis simul et Christianis triumphare possint, unde de disciplina fideque integra, una mensurandis strage, eodem busto componendis, sibi affatim gratulentur. Quid enim de scripturarum canone inter protestantes ipsosque qui se

1 Hammond's Works (ed. I684), vol. Iv. p. 74I. 


\section{Under James I and Charles I}

evangelicos nuncupant recepto, de diei Dominicae observatione, aut e scriptura aut ex universo antiquitatis penu

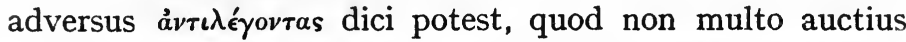
et cumulatius pro episcopali dignitate contra paritatis presbyteranae assertores dici poterit?

Then in a pathetic passage this faithful son of the afflicted church of England defines the position of that church upon this question :

Certe ab hoc novatorum scopulo sibi diligenter cautum esse voluit Dilectissima Mater nostra (afflicta, sed ov̉ à $\pi \epsilon \lambda i^{\prime}($ ov $\sigma \alpha)$, ecclesia Anglicana, hoc se universo Christianorum orbi charactere dignoscendam, hoc aequae posteritati aestimandam proponens, quod in controversiis fidei aut $\pi \rho a ́ \xi \epsilon \omega s$ decernendis illud firmum ratumque semper habuerit (et huic basi reformationem Britannicam niti voluerit), ut scripturis primae, dein primorum saeculorum episcopis, martyribus, scriptoribus ecclesiasticis, secundae deferrentur; ideoque quicquid a scripturis affirmatum in fide, quicquid de regimine ecclesiastico ab universa post apostolos ubique disseminata ecclesia constitutum dignoverit, illud pro fixo et stabilito inter articulos religionis ponendum curavit, nemini filiorum suorum quod sic positum fuerit novandum aut movendum permissura ${ }^{1}$.

Hammond's second Dissertation is a scholarly defence of the Ignatian epistles against the prejudiced scepticism of the foreign presbyterians. Hammond had now the edition of Voss (I646) to help him, and the great Dissertation (I644) and Praefatio (I647) of Usher. A request of Usher's had induced Hammond to undertake the task of answering Blondel ${ }^{2}$. The task was perhaps not difficult; the coal, as Bishop Hall expressed it, was too hot for the adversary's

1 Works, vol. IV. p. 742.

2 Wordsworth's Ecclesiastical Biography, vol. IV. p. 35I. 


\section{I38 Under James I and Charles I}

hands to hold ; but Hammond did it well, and added to his discussion an examination of the views of Jerome on episcopacy ${ }^{1}$.

The third and fourth Dissertations deal with the evidence of the Gospels and of the rest of the New Testament. The ground by this time was well trodden, but Hammond found a good deal that was new to say, and said freshly what had been said before. His conclusion is the usual one :

Ex istis sic positis illud statim certissimum et lucidissimum exurgit, his duodecim in terris Christi vicariis, ejus mandato aut diplomate munitis, eademque ratione a Christo missis qua ille a Patre mittebatur, adeo omnem in ecclesia authoritatem in solidum et in integrum commissam esse, ut non ea cuivis mortalium... recte tribui possit, nisi quem apostolorum aliquis in profectionibus aut provinciis ipsorum aut immediate aut mediate in potestatis et authoritatis suae participationem aut successionem admiserit. Hos vero sic admissos, sic 'ipsis succedentes, episcopos aut singulares ecclesiarum praefectos fuisse antiquissimi ecclesiae scriptores a nobis producti satis liberaliter testati sunt ${ }^{2}$.

The fifth Dissertation is on the testimony of Clement, Hermas, and other sub-apostolic writers. The conclusion of the whole work forms a passage very like one which has already been quoted from Jeremy Taylor :

Haec...si cui nondum persuaserint; si post mysterii avouias et antichristi...procul ab episcopis nostris depulsam invidiam; si post Ignatio primaevo martyri et hierarchiae nostrae fidissimo i $\pi \epsilon \rho a \sigma \pi i \sigma \tau \eta$ abstersam labem omnem, authoritatemque ejus firmissimis demum columnis

1 Cp. Lightfoot Ignatius, vol. I. p. 318.

2 Works, vol. Iv. p. 782 . 


\section{Under James I and Charles I}

stabilitam, et testimonia tam frequentia et manifesta ex eo pro episcopis prolata, ut nihil contra apertissimam lucem adhuc vel fingi potuerit, nisi ut Ignatius epistolas nunquam scripsisse credatur; si post ipsius Hieronymi liquidissimas confessiones sic ut causae nostrae satis prolixe suffragari, refragari neutiquam existimandus sit; si post singula hac in re s. scripturarum loca aequa lance perpensa... si post regimen ecclesiae Christianae adeo graphice in is delineatum, ut a Christo magno animarum pastore et episcopo ad singulares apostolos eosdemque episcopos, ab apostolis dein ad singulares in quolibet coetu et proprie dictos episcopos (ipso Christo instituente officium Spirituque sancto personas designante) continua successione derivatum, ad universae tandem per quindecim saecula ecclesiae episcopos (solo per tot saeculorum decursum Aerio contra hiscente) descendisse appareat; si post Clementis Romani (Petri primum diaconi, dein in cathedra ei succedentis episcopi) de episcopis et diaconis ab apostolis ubique constitutis apertissima producta testimonia ; si post aliorum omnium, quos a presbyteranorum partibus stetisse D. Blondelli interest, a strophis et technis ejus vindicatas sententias;... denique si post tot $a b$ omni aevo producta decreta, quibus in universum presbyteris sine episcopo quidvis faciendi potestas abjudicatur, omnisque in ecclesia Christi potestas singularibus episcopis apostolorum successoribus concredita affirmatur, adhuc cuivis dubitandum videatur, annon omnis administrandae ecclesiae (episcopis postmodum natis) presbyterorum consessibus a Christo et apostolis [potestas] tradita fuerit ; si post tantam, inquam, undique circumfusam claritatem adhuc caecutire quisquam aut oculos obfirmare decreverit; unicum certe superest...nempe ut paritatis aut i $\sigma o \tau$. $\mu$ ias presbyteranae origines aut natales juxta positi coram aequis judicibus trutinentur, ut integrae rei gestae annales... dilucide et ex ipsis seu $\chi \epsilon \iota \rho \tau \tau \hat{\omega} \nu$ seu a desumpti et a primo parente, dicam ? an creatore ? Johanne Calvino ad ultimum D. Blondellum deducti conscribantur ${ }^{1}$.

1 Works, vol. IV. p. 840. 
In an earlier work on the Power of the Keys ( 1647 ) Hammond had already stated his belief that the bishops are the successors of the apostles:

The only difficulty remaining in the point will be, Who are the apostles' successors in that power? and when the question is asked of that power, I must be understood of the power of governing the church peculiarly (of which the power of the keys was and is a principal branch) ; for it must again be remembered that the apostles are to be considered under a double notion, as planters, then as governors, of the church. ...I answer that it, being a matter of fact or story later than that the scriptures can universally reach to it, cannot be fully satisfied or answered from thence, any further than the persons of Timothy or Titus etc., and the several angels of the churches in the Apocalypse (who are acknowledged by all the ancients to be single persons that had power over all others in those churches), but will in the full latitude through the universal church in those times be made clear from the next evidences that we have, viz. from the consent of the Greek and Latin fathers, who generally resolve that bishops are those successors. This I shall not be so unreasonable as to attempt to prove at large through the writings of those fathers, but content myself with one or two of the first of them ${ }^{1}$.

He gives the evidence of Clement of Rome, Ignatius, and Cyprian, and then proceeds to state the bearing of the evidence upon the question of presbyterian orders :

And if it be demanded here, What it is which in our church is given to presbyters in their ordination as the full importance of the form then used, Receive the Holy Ghost, I answer, Not all that is at any time contained under that phrase, when it is used in the consecration [of bishops], but

${ }^{1}$ Works, vol. 1. 412. Cp. the treatise "On Imposition of Hands for Ordination," ibid. p. 637. 


\section{Under James I and Charles I}

only the particulars which are after mentioned; and so distinctly not the power of ordaining, which is not mentioned, and which is a particular that never was regular for any presbyter in the ancient church to assume to himself, or to any number of that order without a bishop over them ;... and if the practice of some few protestant churches in this last century be opposed against it, then first, I shall conceive those very unfit to be confronted against the universal for r500 years; and therefore, secondly, I shall not doubt to affirm, that want is not only a defect but a corruption among them. Thirdly, it will be observable that even those that want it among them have formerly thought fit to excuse it by the case of necessity, and to acknowledge it their infelicity but not their fault (their superiors in the state not permitting them to have bishops to ordain them), and to give their judgments freely, that where episcopacy is, it is to be preserved, and where it is not, it is to be wished for ; which is a sufficient expression of their sense of it.... And then fourthly, that this cannot be applicable by way of excuse to those who desire to cast out bishops where they are, on purpose that presbyters may usurp the power which belongs to them ${ }^{1}$.

In the Considerations concerning the Change of Church-Government, published in 1644, Hammond wrote that it was a sin against religion to substitute presbytery for episcopacy :

because this government by bishops superior to presbyters is of apostolical institution. But this being an affirmation as demonstrable by ecclesiastical records as any thing can be, or as the canon of scripture which we receive is demonstrated to be the canon of scripture, and in regard it hath by others been sufficiently proved, I shall therefore wholly spare the repeating of that trouble, and add unto it, that it hath the example, though not the direct precept, of Christ, who with his twelve apostles and the many other disciples,

1 Works, vol. I. p. $4^{19}$. 
in time of his residence upon earth, superior one to the other, are the copy, of which the bishops, presbyters, and deacons in the following age were a transcript.... Supposing it to be in this manner apostolical, there is little colour of reason to doubt but that the preserving of it is of as great moment as many doctrines of Christianity, not only because many doctrines were not so explicitly delivered by Christ but that they needed farther explicating by the apostles... but also because it was in God's providence thought fit that government should be settled, not by Christ personally, but by the apostles-that is, mediately by Christ, as doctrine was by Christ immediately.... That they may not err in that work, the Holy Ghost is promised to descend upon them, and Christ by that power of his to be with them in eminent manner to the end of the world.... And having gone thus far, I cannot but... appeal to any sober conscience, whether it be not some irreligion thus to displace or remove that which the apostles (to whom only by Christ it was entrusted) according to Christ's own sampler and scripture-grounds thought fit to settle in the church, supposing it to be a matter of religion which is spoken of, as before we proved; nay, whether if an angel from heaven were to be anathematized for teaching any other doctrine than what an apostle had taught, it would not be a matter of just terror to any that should have any part in the guilt of instituting any other government than that which the apostles had instituted ${ }^{1}$.

The next name to be considered after Hammond's is that of Robert Sanderson.

Sanderson, at the request of Charles I, wrote in I647, and published after the restoration, his treatise on Episcopacy not prejudicial to Regal Power. In it he drew, after the manner of Francis Mason, a distinction between the ways in which a thing can be said to claim the jus divinum. Sometimes it

1 Works, vol. I. pp. 398 foll. 


\section{Under James I and Charles I}

imports a positive divine precept : sometimes it is used of things which are of apostolical institution or practice. Under which of these descriptions does episcopacy come?

Now that the government of the churches of Christ by bishops is of Divine right in that first and stricter sense is an opinion at least of great probability, and such as may more easily and upon better grounds be defended than confuted : especially if in expounding those texts that are alleged for it, we give such deference to the authority of the ancient fathers and their expositions thereof, as wise and sober men have always thought it fit we should do. Yet because it is... needless to contend for more, where less will serve the turn, I find that our divines that have travailed most in this argument...do rather choose to stand to the tenure of episcopacy ex apostolica designatione than to hold a contest upon the title of jus divinum, no necessity requiring the same to be done... Sufficient it is for the justification of the church of England in the constitution and government thereof that it is, as certainly it is, of divine right in the latter and larger signification, that is to say of apostolical institution and approbation ${ }^{1}$.

This is, he says, "a part of the established doctrine of the church of England," as proved both by the ordinal, and by the 36 th of the 39 Articles, and has been constantly and uniformly maintained by our best writers, and by all the sober, orderly, and orthodox sons of the church.

In a postscript to his work, the conscientious Sanderson says that whereas in the work itself he has not made his own judgment clear upon the point, and for want of so doing may perhaps be censured by some to have walked but haltingly, or at leastwise with more

1 Works (ed. Jacobson), vol. v. p. 152. 
caution and mincing than became me to do in a business of that nature, I do hereby declare... that... leaving other men to the liberty of their own judgments, my opinion is that episcopal government is not to be derived merely from apostolical practice or institution, but that it is originally founded in the person and office of the Messias, our blessed Lord Jesus Christ: who...did... send and empower his holy apostles, giving them the Holy Ghost likewise as his Father had given him, in like manner as his Father had before sent him, to execute the same apostolical, episcopal, and pastoral office for the ordering and governing of his church until his coming again; and so the same office to continue in them and their successors unto the end of the world. This I take to be so clear from [certain] texts of scripture, that if they shall be diligently compared together, both between themselves and with the following practices of all the churches of Christ, as well in the apostles' times as in the purest and primitive times nearest thereunto, there will be left little cause why any man should doubt thereof ${ }^{1}$.

It was Sanderson who in 1647 led the University of Oxford in their spirited yet temperate refusal to take the Solemn League and Covenant, and drew up the reasons for refusing. Among other reasons, the Oxford men affirm

We are not satisfied how we can with a good conscience swear to endeavour the extirpation [of episcopacy]....

We think we have reason to believe that it is, if not jure divino in the strictest sense, that is to say, expressly commanded by God in his word, yet of apostolical institution : that is to say, was established in the churches by the apostles according to the mind and after the example of their Master, Jesus Christ, and that by virtue of their ordinary power and authority derived from him, as deputed by him governors of his church ${ }^{2}$.

1 Works, vol. v. p. I9I.

2 Ibid. vol. IV. p. 392. 


\section{Under James I and Charles I}

They proceed to enlarge upon the universality of the institution, and urge (as Saravia did before, and Pearson at a later time) that the abolition of it

would give such advantage to the papists, who usually object against us and our religion the contempt of antiquity and the love of novelty, that we should not be able to wipe off the aspersion.

\section{It would also}

so diminish the just authority due to the consentient judgment and practice of the universal church, the best interpreter of scripture in things not clearly expressed, that without it we should be at a loss in sundry points both of faith and manners at this day firmly believed and securely practised by us ${ }^{1}$.

The celebrated and much-abused archbishop around whom these men, from Hall onwards, were moving had no occasion to write any treatise on the subject of episcopacy. His main controversy lay in another direction. But Laud's views on the point are not left to conjecture. His delightfully brotherly letters to Bishop Hall about his book are a sufficient testimony:

You say in the first head, that episcopacy is an ancient, holy, and divine institution. It must needs be ancient and holy, if divine. Would it not be more full, went it thus, " so ancient as that it is of divine institution?"... Again, you say in that first point, that where episcopacy hath obtained, it cannot be abdicated without violation of God's ordinance. This proposition I conceive is inter minus habentes, for never was there any church yet where it hath not obtained; the Christian faith was never yet planted anywhere:

1 Works, vol. IV. p. 394. 


\section{I46 Under James I and Charles I}

but the very first feature of the body of a church was by or with episcopacy; and wheresoever now episcopacy is not suffered [i.e. by the professing church itself] to be, it is by such an abdication; for certainly there it was a principio.

In your second head, you grant that the presbyterian government may be of use, where episcopacy may not be had. First I pray you consider whether this concession be not needless here, and in itself of a dangerous consequence. Next I conceive there is no place where episcopacy may not be had, if there be a church more than in title only. Thirdly since they challenge their presbyterian fiction to be Christ's kingdom and ordinance (as yourself expresseth), and cast out episcopacy as opposite to it, we must not use any mincing terms, but unmask them plainly; nor shall I ever give way to hamper ourselves for fear of speaking plain truth, though it be against Amsterdam or Geneva; and this must be sadly [i.e. seriously] thought on.

Concerning your Postulata I shall pray you to allow me the like freedom....Episcopacy is not so to be asserted to apostolical institution as to bar it from looking higher, and from fetching it materially and originally, in the ground and intention of it, from Christ himself, though perhaps the apostles formalised it 1 .

Upon this point the archbishop proceeds to enlarge, not only as against " the furious Aerian heretics (out of which are now raised. . . our Scottish masters)," but also some " of a milder and subtiler alloy, both in the Genevan and the Roman faction."

In a second letter Laud has one or two interesting observations to make :

First, you do extremely well to distinguish the Scottish business from the state of the foreign churches; but yet to those churches and their authors you are a little more favourable than our case will now bear...

${ }^{1}$ Works (ed. 1857), vol. vi. pp. 573 foll. 


\section{Under James I and Charles I}

The third [particular], which you seem to pass by as not much material in the question, is in our judgment here the very main of the cause; and it is, whether episcopacy be an order or degree. An order certainly, if it be of divine and apostolical institution.... And why does the church of England ordain or consecrate every one that is made a bishop, if it be but a degree of the same order? For when a bishop is translated, or made an archbishop, there's then no consecration, because they are...only degrees 1 .

That the episcopate is jure divino had formed the subject of Laud's tenet for the degree of Doctor of Divinity $^{2}$. His Diary shows the state of his opinion many years before the writing of Hall's book. Under the date Jan. $17, \mathrm{r} 626$, occurs the memorandum:

Wednesday, I show my reasons to the King, why the papers of the late Bishop of Winchester concerning bishops, that they are jure divino, should be printed [they were Andrewes' letters to $\mathrm{Du}$ Moulin]; contrary to what the Bishop of Lincoln [Williams] had pitifully and to the great detriment of the church of England signified ${ }^{3}$.

The editors of Laud's works quote Bishop Hacket's comment upon this passage, which is interesting as giving Hacket's if not Williams's conception of the bishop's office :

A great mistake, for Lincoln ever defended the divine right of his order, that it was necessary in a church rightly constituted, that it was a main defect in them that had not that presidency among them; but the less if they did desire it and could not enjoy it.

1 Works, vol. vi. p. 577. The dates of the two letters are Nov. I I, I639, and the following Jan. I4.

2 Ibid. vol. III. p. 262.

3 Ibid. p. I99.

- Scrinia Reserata, par. II. p. 87. 
Naturally his belief in the apostolical succession was brought up against Laud at his trial :

The next charge was out of Dr Pocklinton's Altare Christianum, pp. 49, 50, where he speaks (they say, for I now have not his book) of a happiness that the bishops of England can derive their succession from St Peter: which in great scorn Mr Nicolas called the " archbishop's pedigree."...He may scorn what he will; but wise men know it is a great honour to the church of England, and a great stopple in the mouths of the Romanists, that her bishops can derive their calling successively from St Peter ; especially considering how much they stand upon personal succession. [And] Dr Pocklinton in this says no more for me and the bishops than St Augustine urged for himself and his brethren against the Donatists in the same words.... But it seems an upstart clergy without a calling will serve Mr Nicolas well enough ${ }^{1}$.

The day before this charge was preferred, Laud's hostility to the foreign churches, had been alleged before the court :

This day they charged upon me the twelfth Original Article, which follows in these words :

$\mathrm{He}$ hath traitorously endeavoured to cause division and discord between the church of England and other reformed churches; and to that end hath suppressed and abrogated the privileges and immunities which have been by his Majesty and his royal ancestors granted to the French and Dutch churches in this kingdom; and divers other ways hath expressed his malice and disaffection to those churches ; that so, by such disunion, the papists might have more advantage for the overthrow and extirpation of both.

The first charge is, " that I deny them to be a church": for they say, " that I say plainly in my book against Fisher,

1 Troubles and Trial, day 19 (Works, ed. 1854, vol. IV. p. 339). 


\section{Under James I and Charles I}

that No Bishop, no Church. Now it is well known that they have no bishops, and therefore no church." The passage in my book is an inference of St Jerome's opinion, no declaration of my own. And if they or any other be aggrieved at St Jerome for writing so, they may answer him. Mr Nicolas added, " that this was seconded by Bp Mountague's book, which Mr Pryn" (carefully) "witnessed was found in my study, and licensed by Dr Braye "...I cannot make them any fuller answer without viewing the place, than themselves help me to by their own confession. Which is, that he adds this exception, that none but a bishop can ordain, but in casu necessitatis, which is the opinion of many learned and moderate divines. "Yet this is very considerable in the business, whether an inevitable necessity be cast upon them, or they pluck a kind of necessity upon themselves ${ }^{1 .}$

That he had laboured to bring England back to the communion of Rome was, of course, the great charge laid against Laud. He had said, so it was affirmed, that the Roman church and the English were of one religion, and that the English church and the foreign protestants were of different religions. In the recapitulation of his trial he touches upon both points. His enemies sought to convict him of treason :

By a passage in my book, where I say, " the religion of the papists and ours is one" : but that's expressed at large, only because both are Christianity; and no man, I hope, will deny that papists are Christians. As for their notorious failings in Christianity, I have in the same book said enough of them...

By my making the Dutch churches to be of another religion. But this is mistaken (as my answer will show the reader). And if they do not make themselves of another religion, I shall never endeavour to make them ${ }^{2}$.

\footnotetext{
1 Works, vol. Iv. p. 307.

2 Ibid. pp. 377, 378.
} 


\section{I50 Under James I and Charles I}

To the special and particular charge of unkind treatment of the foreign congregations in England Laud had his reply to make. These congregations had adopted a schismatic attitude towards the church of England.

This I found, that they did not use their privileges with that gratitude and fairness to his Majesty, the state and church of England, as they ought to have done...

I. That they living as they did and standing so strictly to their own discipline wrought upon the party in England which were addicted to them, and made them more averse than otherwise they would have been to the present government of the church of England.

2. That by this means they lived in England as if they were a kind of God's Israel in Egypt, to the great dishonour of the church of England, to which at first they fled for shelter against persecution.... It grew up and encroached upon us, till it became a church within a church, and a kind of state within a state. And this I ever held dangerous, how small beginning soever it had...

The third objection was a purely secular one: the foreigners would not learn English, nor teach Englishmen their trades.

4. That for religion, after so many descents of their children born in the land, and so native subjects, these children of theirs should refuse to pray and communicate with the church of England, into whose bosom their parents fled at first for succour, I thought then, and do still, that no state could with safety or would in wisdom endure it. And this concerning their children was all that was desired by $\mathrm{me}^{\mathbf{1}}$.

Laud has been made to bear much obloquy for this behaviour, even in our own times; but his

1 Works, vol. III. pp. 422 foll. 


\section{Under James I and Charles I I5I}

policy cannot be called unreasonable in view of the circumstances of the time. It was certainly never intended that the Walloons should continue to be a sect apart for ever, when they had become naturalised subjects of the crown ${ }^{1}$.

For matters of a more general kind, Laud interested himself in Dury's work of reconciliation, and contributed to the expenses of it. He wrote to him in 1634 :

Ego certe quam primum spem de pace reformatarum ecclesiarum conceptam audivi, perfusus sum gaudio, nec desunt preces meae quotidianae obsidentes Deum pacis, ut spem qualem-qualem messis tam gloriosae, tam frugiferae, ad maturitatem perduceret. Quodque in me erit, dum fata sinunt, omni labore contendam, ne operi Christiano nomine tam digno deesse videar. Quin et probe scio ecclesiae Anglicanae opus hoc gratissimum fore ${ }^{2}$.

It would not be right to pass over with only an allusion the remarkable man whose works it was a sin in the eyes of the puritans to possess,-Richard Mountague, who made it his aim " to stand in the gap against puritanism and popery, the Scylla and Charybdis of ancient piety ${ }^{3}$." The damning passage was a vigorous statement of what Mountague took to be the doctrine of the church of England on the subject of the church and the ministry, as against both the Scylla and the Charybdis aforesaid :

1 See Heylin Cyprianus Anglicus, pp. 276 foll.

2 Works, vol. vir. p. II2. There are several other letters of his about Dury's work.

${ }^{3}$ See his letter in Cosin's Correspondence (Surtees Library), vol. I. p. 2 I. 
Iniquius hic agunt cum ecclesia Anglicana, qui tenere et tueri illam mentiuntur, non esse de necessitate vocationem et missionem pastorum, ministrorum, vel sacerdotum ordinariam per manuum impositionem. Sancte credimus, accurate tuemur, et defendimus, extitisse, extare, extituram semper contra omnes inferni et daemonum machinationes ecclesiam et $\sigma v v a \gamma \omega \gamma \eta \dot{\nu}$ hominum in Christum credentium, evocatorum: caeterum, nullis interceptam intercisam intercapedinibus, perpetuo extantem alicubi, visibilem, oculis usurpandam in eum finem et eo modo, ut intelligere possint quibus curae illud est, apud quos habeatur verbum vitae, sacramenta salutaria administrentur, sacerdotium rite delegetur: esse, fuisse, futurum esse ordinem illum ecclesiasticum sacerdotalem, in ecclesia visibili constitutum, agnitum, agnoscendumve... hoc ipsum officium et munus in ecclesia sive apostolicum sive sacerdotale adeo esse de necessitate salutis ordinaria, ut sine altero alterum esse nequeat.

Non est sacerdotium nisi in ecclesia, non est ecclesia sine sacerdotio. Illud autem intelligo per $\chi_{\epsilon \iota \rho} 0 \theta \epsilon \sigma i a v$ episcopalem ordinariam. Neque enim admittenda[m] censemus extraordinariam aliquam seu vocationem seu $\lambda_{\epsilon \iota r o v \rho \gamma i ́}$, nisi miraculosam. Oportet omnino miraculis agant et suam confirment functionem signo aliquo, qui non ab episcopis, derivata $a b$ apostolis per successionem institutione, in ecclesiam inducuntur. Nam quod praetendunt, ordinariam vocationem retinendam, adhibendam, eique adhaerescendum, nisi in casu necessitatis, absurdum est, et suppositione innititur impossibilitatis ; neque enim talis casus aut extitit aliquando aut contingere potest, nisi fallat nos Dominus qui promisit, Portae inferorum non praevalebunt ${ }^{1}$.

The author of the Gag for an old Goose had much more to say on behalf of bishops, in forms grave and gay.

One other author may be mentioned here. Heylin's chief activities as a writer belong to a 1 Origines Ecclesiasticae, II. p. 463. 
somewhat later period, but his connexion with Archbishop Laud is so close that his opinion ought to be recorded near that of his English Cyprian. There is no great originality, however, in his treatment of the earliest period of the history of episcopacy. He affirms that

There are two things to be declared and made evident; first, that the power of ordination was so inherent in the person of a bishop, that he alone both might and did sometimes ordain without help of presbyters ; and secondly, that the presbyters might not do the same without the bishop ${ }^{1}$.

$\mathrm{He}$ comes to foreign presbyterianism. His attitude is marked by greater reserve than might have been expected.

Against all this I meet with no objection in antiquity.... This present age doth yield one, and a great one too, which is the case of the reformed churches beyond the seas; who, finding an averseness of the bishops at the first to give them orders, unless they would desert the work of reformation which they had in hand, were fain to have recourse to presbyters for their ordinations; in which estate they still continue... . The bishops thus refusing to admit them into holy orders, which was the public ordinary door of entrance into the ministry of the church, necessity compelled them at the last to enter in by private ways and impose hands on one another.

Heylin illustrates their position by the story of Scipio, who took the keys from the legally minded quaestor and opened the aerarium himself for the good of the state. The illustration had been used before by Crakanthorp.

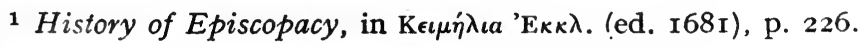




\section{I54 Under James I and Charles I}

This I conceive to be the case at the first beginning. But whether with the change of their condition the case be altered, or whether they continue in the state they were, I am not able to say anything. It is a good old saying, and

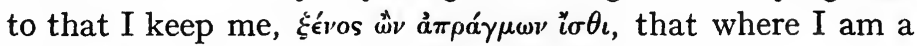
stranger, I must be no meddler ${ }^{1}$.

It would be unfair to judge Archbishop Laud entirely by his association with men of the stamp of Heylin, as if there were no other side to his mind and character. He was the patron of many liberalminded men,-among them, of Chillingworth. Chillingworth left a brief memorandum of his opinion on episcopacy, apparently written about I642, the year before his death. The memorandum was intended to assuage the rising indignation against bishops. The subject is stated at the outset with an ironical moderation which was calculated to disarm opposition.

If we abstract from episcopal government all accidentals, and consider only what is essential and necessary to it, we shall find in it no more but this; an appointment of one man of eminent sanctity and sufficiency to have the care of all the churches within a certain precinct or diocese, and furnishing him with authority (not absolute or arbitrary, but regulated and bounded by laws, and moderated by joining to him a convenient number of assistants), to the intent that all the churches under him may be provided of good and able pastors, and that both of pastors and people conformity to laws and performance of their duties may be required, under penalties not left to discretion, but by law appointed $^{2}$.

1 History of Episcopacy, pp. 228 foll.

2 Works (ed. 1838), vol. II. p. 485 . 


\section{Under James I and Charles I}

Chillingworth speaks of the system with a seeming personal detachment :

To this kind of government I am not by any particular [i.e. private] interest so devoted as to think it ought to be maintained either in opposition to apostolic institution, or to the much desired reformation of men's lives and restoration of primitive discipline, or to any law or precept of our Lord and Saviour Jesus Christ ; for that were to maintain a means contrary to the end; for obedience to our Saviour is the end for which church government is appointed. But if it may be demonstrated (or made much more probable than the contrary), as I verily think it may, I. That it is not repugnant to the government settled in and for the church by the apostles; II. That it is as compliable with the reformation of any evil which we desire to reform either in church or state, or the introduction of any good which we desire to introduce, as any kind of government; and III. That there is no law, no record of our Saviour against it: then I hope it will not be thought an unreasonable motion, if we humbly desire those that are in authority, especially the high court of parliament, that it may not be sacrificed to clamour or overborne by violence; and though (which God forbid) the greater part of the multitude should cry, "Crucify, Crucify," yet our governors would be so full of justice and courage as not to give it up, until they perfectly understand concerning episcopacy itself, quid mali fecit?

Chillingworth argues briefly but forcibly from the admission of men like $\mathrm{Du}$ Moulin and Beza, who acknowledged that episcopacy was universal very shortly after the apostles' time, that it must be carried back to the apostles themselves.

When I shall see therefore, he concludes, all the fables in the Metamorphosis [of Ovid] acted and prove true stories ; when I shall see all the democracies and aristocracies 
in the world lie down and sleep and awake into monarchies ; then will I begin to believe that presbyterial government, having continued in the church during the apostles' times, should presently after (against the apostles' doctrine and the will of Christ) be whirled about like a scene in a masque and transformed into episcopacy. In the meantime, while these things remain thus incredible, and, in human reason, impossible, I hope I shall have leave to conclude thus :

Episcopal government is acknowledged to have been universally received in the church presently after the apostles' times. Between the apostles' times and this " presently after" there was not time enough for, nor possibility of, so great an alteration. And therefore there was no such alteration as is pretended. And therefore episcopacy, being confessed to be so ancient and catholic, must be granted also to be apostolic: quod erat demonstrandum ${ }^{1}$.

It may be worth while to refer here to the opinion of the learned Joseph Mead, or Mede,-an independent, if somewhat eccentric, scholar.

In one of his sermons he clearly adopts the twoorder theory of the ministry, but as clearly traces the division in the superior order to divine institution:

There are properly but two orders ecclesiastical, presbyteri and diaconi; the one the masters, priests; the other the ministers, deacons. The rest are but divers degrees of these two. As bishops are a degree of presbyters of divine ordinance, to be as heads, chiefs, and presidents of their brethren, so subdeacons, lectors, and indeed any other kind of ecclesiastical ministers... are all a kind of deacons, being to the presbyters, either single or episcopal, as the levites were to the sacerdotes in the Old Testament, namely to minister unto or for them. Thus when we say, bishops, presbyters, and deacons, we name but two orders, yet three degrees. 
Mead takes offence at any minister being described as a minister of the church, or of this or that church : they are the ministers of God.

It is an enormous conceit that some maintain that the power of sacred order and of the keys is given by God immediately to the body of the congregation, and that they depute him who is their minister to execute the power which is originally in them. That power is conferred by God immediately to those who are bishops and pastors, and by and through them belongs to the whole body and no otherwise. Sed tantum potuit incommodi sermonis usus ${ }^{1}$.

No one in England was more friendly to the work of Dury among the foreign protestants than Mead was. At the outset, however, he was somewhat loth to declare his views, because, he says, writing in 1637 , it had come about

ut quo quis in exteras ecclesias proniorem se ostendat, eo statim a nostra habeatur alienior ${ }^{2}$.

Writing to Hartlib on the subject he says :

Our church, you know, goes upon differing principles from the rest of the reformed, and so steers her course by another rule than they do. We look after the form, rites, and discipline of antiquity, and endeavour to bring our own as near as we can to that pattern. We suppose the reformed churches have departed farther therefrom than needed, and so we are not very solicitous to comply with them; yea, we are jealous of such of our own as we see over-zealously addicted to them, lest it be a sign they prefer them before their mother. This I suppose you have observed, and that this disposition in our church is of late very much increased. Well then, if this union sought after be like to further and

1 Works (ed. 1664), pp. 34, 35.

${ }^{2}$ Ibid. p. 986. 


\section{58 Under James I and Charles I}

advantage us in the way we affect, we shall listen to it. If it be like to be prejudicial, as namely to give strength and authority to those amongst us who are enamoured with the foreign platform, or bring a yoke upon our own by limiting and making us obnoxious, we'll stand aloof and not meddle with it, lest we infringe our liberty...

For myself, I am so far inclinable to peace that I can yield to a Christian communion at as great a distance of opinions as any protestant whatever. For I hold communion is not to be broken but for fundamentals; of which kind I take none of the differences between the Calvinists and Lutherans to be. Yet am I not so well versed in the subtilties of these controversies as I think fit to adventure my judgment to the public view... . Nor do I think this union, which every true Christian ought so much to desire, will ever be brought to pass by a full decision of the controversies, but only by abating of that vast distance which contention hath made, and approaching the differences so near as either party may be induced to tolerate the other, and acknowledge them for brethren and members of the same body ${ }^{1}$.

The growing alienation from the foreign reformed churches, which Mead noticed and deplored, was largely due, in his opinion, to the intemperate zeal with which some nominal churchmen at home held them up to admiration, to the disparagement of their own church.

Like Davenant, Mead does not mention episcopacy as one of the things that enter into the question of communion between the churches; but he is not speaking of communion between the church of England and the foreign ones; he is speaking of communion between the foreign churches among

1 Works, pp. ro6r, то62. 


\section{Under James I and Charles I}

themselves. Dury himself perhaps alluded to it, where he said in a letter to Mead that the schisms of reformed Christendom arose " partim ex amissa pristinae disciplinae regula." Perhaps Mead intended to allude to it when in his reply, addressed to Hartlib, he wrote as follows:

What if...we should...make two sorts of fundamental articles,-fundamentals of salvation, and fundamentals of ecclesiastical communion?... Concerning the second sort,... it is not fit that the church should admit any to her communion which shall professedly deny or refuse their assent to such catholic truths as she hath anciently declared by universal authority for the symbol and badge of such as should have communion with her. And this sort of articles without doubt fetches a greater compass and comprehends more than the other, as being ordinate and measured by another end, to wit, of discipline, and so contains not only such truths, the knowledge whereof and assent whereto is necessary unto the being of Christian life, but also to the wellbeing thereof ${ }^{1}$.

The gentle Henry Ferne, afterwards Bishop of Chester, published in I647 a little pamphlet called Episcopacy and Presbytery considered. It was not intended for the learned theologian; it aimed at showing which was the more serviceable. But the ancient sanction of episcopacy was not to be neglected in drawing up the accounts.

He that with a discerning eve (as wise men should) looks, upon a bishop, may in that person and his government easily see what is original and apostolic, what brought in after... and can sever what is accidental from what is essential.

1 Works, p. 1066. 
The essential is, of course, the government by one, however restricted by rules, with " authority for ordination and jurisdiction."

That there is such a power of ordination and jurisdiction left in the church by our Saviour Christ, and to continue in it, for the ordaining and sending forth ministers of the gospel... is a truth confessed on all sides. That the ministration of this power was not left indifferent to all presbyters or ministers of the gospel, but restrained to certain choice men...for the more orderly government of the church is a truth also, current for I500 years in the catholic church, however in this last age opposed with all violence by presbyterians ${ }^{1}$.

The usual scripture evidences are briefly given, but Ferne rightly observes:

It could not be expected that the episcopal power should show itself in any persons distinct from the apostles till the churches planted abroad were so enlarged by the access of new converts that there was need of many presbyters to minister in them, and so of a bishop as chief pastor to take care of the whole, and still to send out new labourers as the harvest increased. For though the churches abroad at their first planting were not without order, such as they were capable of, being visited by the apostles or their fellow labourers... yet had they not at first such an order by bishops and presbyters settled among them, as they had when it seemed good to the apostles so to provide for them ${ }^{2}$.

Then came the Timothies and others.

In 1653 the same author wrote a more serious, but brief, work in defence of Anglican orders against opponents on the other side,-Certain Considerations

1 Episcopacy and Presbytery considered, p. 3.

2 Ibid. p. 4. 


\section{Under James I and Charles I}

I6I

of present Concernment touching this Reformed Church of England, against the Jesuit Champny. One of Champny's arguments was derived from the relations between the church of England and the foreign reformed churches.

He urges that they renounce our plea of having ordination by bishops,... esteeming them antichristian, and pleading extraordinary vocation; from whence he concludes against them that they have no lawful pastors, therefore no church : and consequently against us, that we are bound by our plea of ordination by bishops... to renounce the fellowship of those churches, which hitherto we accounted of as sisters, and to stand alone, divided from all other churches, as we are from the Roman, and to hold the church of England the only true church, thereby confining the catholic church within the bounds of that kingdom, which... will be too too narrow ${ }^{1}$.

Ferne replies that we are not immediately concerned with the condition of the foreign reformed churches; but he wholly denies the last part of the objection. "We do not exclude the Roman church" itself " out of the bounds of the catholic church." "Much less do we exclude the Greek and Eastern churches, who have their ordination and succession of pastors from the apostles, as well as the Romish church."

Yea, and we may add here, we cannot exclude those reformed, which want the regular way of ordination, from belonging to the catholic church ${ }^{2}$.

He observes, however, that not all the reformed churches abroad are without bishops.

1 Certain Considerations, etc., p. 93.

2 Ibid. p. 94.

M. 
Those churches which are the remains of the ancient reformed Bohemians, and are now in and about Poland or those parts, do still retain bishops... . Neither are Denmark and Sweden without their bishops; and therefore Champny's other inference, that in this plea of ordination by bishops ... we of England stand alone, is also false ${ }^{1}$.

Turning to the consideration of the other churches, Ferne says that their judgment has often been expressed in our favour:

Now for their practice, not conformable to that judgment, as we cannot approve of it, so are we ready to excuse their failing, so far as the necessity they plead will bear, leaving it to the Romanists desperately to cut off nations and people from the church for failings and wants in such things as do not touch the very life and being of a church or of the members of it ${ }^{2}$.

Ferne does not make light of the importance of a duly accredited ministry :

Wilful omission or rejection of it is not only a great sin and sacrilege committed against the commandment and appointment of Christ and his apostles, but also such a breach of charity in them who are guilty of it that it renders them schismatical, and so far disjoined from the body of Christ, which is his church, as they stand guilty of $i^{3}$.

Nevertheless, the faith is of more importance than the polity, and, where the faith is maintained, and the due order wanting on account of uncontrollable circumstances,

we must look at those who are in such a condition, without pastors regularly ordained, as at churches defective and not completely framed, but in a capacity or expectation

1 Certain Considerations, etc., p. 94.

2 Ibid. p. 99.

3 Ibid. p. I04. 


\section{Under James I and Charles I $\quad 163$}

of receiving their completion, when that necessity which enforces the defect is removed, and so continuing as well as they may, rather than to give up that truth and purity of Christian doctrine they have attained to ${ }^{1}$.

Such pastors as they have are

pastors by a moral designation to the office, rather than any real or due consecration, which only is in those hands that have received the power of sending or ordaining pastors from the apostles ${ }^{2}$.

Ferne discusses the question whether bishops are a separate order. Evidently his own feeling is that they are; but he leaves the matter open. There is something to be said for either view :

Of the two forementioned ways of conceiving the ordaining power to be estated by the apostles...upon... bishops... I suppose the first way, which conceives it superadded as a distinct power to their priestly function, to be the clearer for securing the episcopal function and distinguishng it from the other; but the second way, which conceives that power radically diffused and communicated in the very order of the priestly function, and restrained to such select persons in the exercise of it, the faculty or immediate power whereof they received by consecration, I suppose to be more easy and expedient for a peaceable accord of the difference in hand, and yet safe enough for episcopal ordination ${ }^{3}$.

This section of the present survey may well end with the words of a venerable man who had been the friend of Andrewes and Overall, and who died at the age of ninety-five in the year before the restoration of Charles II. Thomas Morton, Bishop of

1 Certain Considerations, etc., p. 105.

3 Ibid. p. 118.

2 Ibid. p. I Iо. 


\section{I64 Under James I and Charles I}

Durham, whose chaplain Ferne had been, wrotethough the little book was only published in I670, after his death, with an interesting preface by Sir

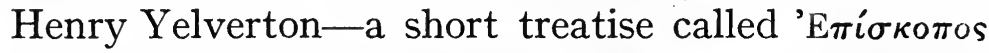

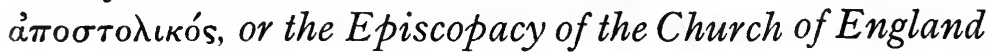
justified to be Apostolical. The method is somewhat unusual. It starts with the "pole-star" of the church of Geneva, Calvin, "peremptorily asserting the right of episcopal government in what church soever, that professeth the truth of doctrine and denieth dependence on the Roman Antichrist." It then ascends to the patristic evidence, and then to the scriptural.

Antiquity, Morton says, speaketh unto us both by its profession and practice; sometimes professing it to be so far according to the word of God as it is apostolical, sometimes in an higher tone and accent to attribute unto it a divine right ${ }^{1}$.

After discussing some patristic testimonies, Morton says :

These ecclesiastical testimonies being so manifold, so pertinent, so perspicuous, and so freely confessed, we doubt not but that ingenuous readers will prefer antiquity before novelty, universality before paucity, solemnity of profession before obscurity, and this fully testified apostolical practical succession before the refractoriness of any whomsoever ${ }^{2}$.

When he comes to the New Testament, Morton begins by showing how imperious St Paul was in the use of his authority over the churches. The same authority was transmitted to the apostolical disciples,

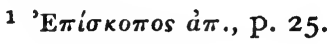

2 Ibid. p. 54 . 


\section{Under James I and Charles I $16_{5}$}

like Timothy. The right of episcopacy to be considered apostolic being thus proved, Morton ends by showing that it is divine;-the supreme proof of which is, to him as to others, the approval of the " angels" of the Apocalypse by the heavenly Christ ${ }^{1}$.

Morton in his last will gives an account of his faith, because, as he says, he felt it necessary " in this last and worst age of the church for all bishops to leave some testimony of their faith to the world...that so neither their names may be traduced after their death, nor any weak brother misled by fathering any false opinions upon them.". In the course of this touching profession the bishop writes:

Concerning which order [of bishops] I profess to believe that it was instituted by the apostles, who were infallibly inspired by the Holy Ghost, and approved by Christ in the Revelation of St John, and consequently to be of divine institution... and I had never sustained the burthen of that office above forty years in the church, if this had not been always my judgment concerning bishops. I pray God restore them again to those poor afflicted parts of his church where either the office or the exercise of it is wanting.... If I had not believed upon sufficient evidence that the succession of bishops in the church of England had been legally derived from the apostles, I had never entered into that high calling, much less continued in it thus long...

As for our brethren the protestants of foreign reformed churches, the most learned and judicious of themselves have bewailed their misery for want of bishops. And therefore God forbid I should be so uncharitable as to censure them for no-churches, for that which is their infelicity, not their fault. But as for our perverse protestants at home, I cannot say the same of them, seeing they impiously reject

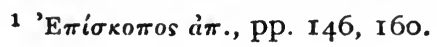


that which the other piously desire. And therefore I cannot flatter those in this church who have received their ordination only from mere presbyters so far as to think them law fully ordained. St Jerome himself reserved to the bishop the power of ordination. Seeing therefore I have been, as I hear, so far misunderstood by some among us as to be thought to approve of their ordination by mere presbyters, because I once said it might be valid in case of necessity, I do here profess my meaning to be, that I never thought there was any such necessity in the church of England to warrant it, where (blessed be God for it) there be so many bishops still surviving; and therefore I desire them not to mistake my meaning in that saying...

Having thus far prevented the uncharitableness of others against myself, I do here from my heart profess my unfeigned charity to all the world ; and more particularly both towards those papists and perverse protestants whom I have so much endeavoured to undeceive.... It was only their errors whereat I was offended : I have always loved and pitied their persons, and prayed and laboured for the right informing of their minds and the eternal salvation of their souls. But yet my common charity to them must not supersede my more particular love and obligation which I have to those truly humble and meek souls in the church of England (and more especially in my own diocese of Durham) who still stand firm upon the foundation of a sound faith, and continue obedient to the doctrine of God's word and discipline of his church, without wavering either to the right hand or to the left. And my earnest exhortation to them is, that they would still continue their former affections (notwithstanding all temptations to the contrary) both to the doctrine, discipline, government, and form of worship of this poor afflicted church : which if I did not believe to be the securest way for the salvation of their souls, I had not ventured my own upon the same bottom ${ }^{1}$.

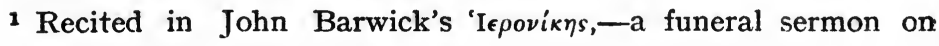
the Bishop, printed 1660 . 


\section{CHAPTER IV}

\section{THE RESTORATION PERIOD}

There can be no doubt that the attitude of the church of England in the matter of episcopacy stiffened at the Restoration in r66o. It was shown even in the alterations made in the preface to the ordinal, though the alterations were only supposed to make clearer the meaning of what was there before $^{1}$. The reasons are not far to seek. The personal sufferings of the episcopalian clergy at the hands of presbyterians and independents were enough to account for it; and the sufferings of the clergy had been shared by the faithful laity. And the cause had been sanctified by at least one great death. The execution of Archbishop Laud would have sufficed to create a reaction in favour of the principles for which he stood; but the martyrdom (for so it was usually reckoned) of Archbishop Laud was thrown into the shade by the martyrdom of King Charles himself. Whatever views may be taken of the character of the king, or of the nature of his policy, it cannot be denied that Charles's death was

1 See W. K. Firminger The Alterations in the Ordinal of 1662, Church Historical Society papers, No. XXXI. 
due to his loyalty to the church of Hooker and Andrewes, whose works, with Laud's and Hammond's, he commended to his children at his parting interview with them, and above all to his maintenance of the divine institution of episcopacy.

In I646, after seeking the advice of Juxon, Duppa, and Sheldon, Charles offered to consent to the establishment of presbyterianism for five years, on the understanding that at the end of that period a " regulated " episcopacy should be instituted,-that is an episcopacy limited by a constitution such as Usher had devised. When Henrietta Maria, from France, urged him to save his throne by surrendering episcopacy altogether, he answered her :

I assure you that the change [to presbyterianism] would be no less, and worse, than if popery were brought in ; for we should have neither lawful priests, nor sacraments duly administered, nor God publicly served but according to the foolish fancy of every idle person; but we should have the doctrine against kings fiercelier set up than amongst the Jesuits ${ }^{1}$.

In the confused state of things which followed, the church of England learned more clearly than ever before the line of demarcation that separated it from the protestant sects which had usurped its place. No doubt a certain number of Anglican priests at home conformed to the system which was forced upon them, and by various artifices succeeded in maintaining something like their former religious methods ${ }^{2}$.

1 See Gardiner's Great Civil War (ed. I 893), vol. III. p. I35.

2 See Perry History of the Church of England (I862), vol. Ir. p. 222 . 
How far such priests were committed to communion with the dominant parties is by no means clear. Probably there were but few occasions when they were called upon to receive the sacrament at the hands of others than themselves; and clearly in their own parochial ministrations they were safe from ecclesiastical irregularity, though they were hampered in the use of the ecclesiastical forms. Men like Thorndike disapproved of the compliances of men like Sanderson, and positively condemned communion with the presbyterians and others ${ }^{1}$. Men less doctrinaire, like Bramhall, made excuses for them ${ }^{2}$. They never felt, as the presbyterians wished them to do, that it was the church of England itself that had undergone a fresh reformation, or that they owed any spiritual allegiance to the new order of things. The religion now set up was not theirs. When they were taunted with the disappearance of their church from off the face of the earth, they felt the sting, though they were not perturbed to find an answer.

You say, writes Bramhall to a Roman Catholic disputant, [that our church] hath no more any subsistence in the world, nor pretence to the privilege of a church. ...Wheresoever there is a lawful English pastor, and an English flock, and a subordination of this flock to that pastor ${ }^{3}$, there is a branch of the true English protestant church. Do you make no difference between a church persecuted and a church extinguished? Have patience, and expect the catastrophe. It may be, all this while the Carpenter's Son

${ }^{1}$ See below, p. 189, and compare Stoughton Religion in England, vol. II. p. 3 I 8 .

2 See below, p. 2 II.

${ }^{3}$ The phrase comes from Cyprian. 
is making a coffin for Julian. If it please God, we may yet see the church of England, which is now frying in the fire, come out like gold out of the furnace, more pure, and more full of lustre. If not, his will be done. " Just art thou, $\mathrm{O}$ Lord, and righteous are all thy judgments ${ }^{1}$."

Many, both of the clergy and of the laity, went abroad, like the writer just quoted ${ }^{2}$. In some places, as at Paris, they had facilities for using their own services in an embassy chapel or elsewhere; but in others the question whether it was lawful and right to communicate with the native protestants (to communicate with the Roman Catholics without going over to them was impossible) became acute. It was not a question that had been positively and authoritatively decided. English church writers had generally assumed that there was intercommunion between their church and the foreigners, but no formal acts had established it. Perhaps no such act was necessary, unless it could be shown that communion had at some time been formally broken off. But it was by no means certain whether the foreign protestant churches, which were not all in communion with each other, were all ready to admit English churchmen to communion. From the way in which Cosin, for instance, and Jeremy Taylor discuss the matter, it is plain that the individual churchman was left free to decide for himself. Some decided one way, some the other. Cosin communicated; so did his son-inlaw, Granville. Basire, Brevint, Durel, and others,

1 Bramhall's Works (ed. I 842), vol. I. pp. 63 foll.

2 See Perry, ut supra, p. 224. 


\section{The Restoration Period}

whose native language was French, ministered in the French protestant church. Others abstained. There is no sign that Bramhall communicated with the French. Morley certainly did not. Hyde, afterwards Clarendon, refused ${ }^{1}$, though he had his reasons for wishing good relations to be maintained with them. If it had been clear beforehand that the churches were in communion, the refusal would have been inconceivable. A community of interest was undoubted, but there was no public union of the churches.

And it was perhaps not so easy for English churchmen now to communicate with the foreign churches as at an earlier time. They knew more about them than before,-at least about the French, Dutch, and Swiss churches; for Englishmen in general were strangely ignorant of the state of the Lutheran churches. They began to be aware that it was not altogether the misfortune of these churches that they were without bishops. Charitably it had been supposed that they could not help themselves; but it gradually became too plain that some of them, at any rate, were willingly and impenitently presbyterian. They had had reforming bishops among them, or bishops friendly to reform, and had made no use of them. The pretence of necessity was still sometimes resorted to, but not so often or so confidently. There was too close a likeness between the Calvinistic churches of the continent and the mischievous presbyterians at home. A certain aloofness

1 See Hickes's Works, vol. I. pp. 283 foll. (ed. 1847). 
with regard to them seemed not unsuitable for English catholics ${ }^{1}$.

How matters appeared to the English layman and man of affairs is well seen by Clarendon's action in urging Charles II not to go to the French protestant services. The passage in his History is very instructive :

The Lord Jermyn, who in his own judgment was very indifferent in all matters relating to religion, was always of some faction that regarded it. He had been much addicted to the presbyterians from the time that there had been any treaties with the Scots, in which he had too much privity. And now, upon the King's return into France, he had a great design to persuade his Majesty to go to the congregation at Charenton, to the end that he might keep up his interest in the presbyterian party.... The Queen [Mother] did not in the least oppose this, but rather seemed to countenance it, as the best expedient that might incline him by degrees to prefer the religion of the church of Rome... . She well knew... [it] would be a little discountenance to the church in which he had been bred; and from which as soon as he could be persuaded in any degree to swerve, he would be more exposed to any temptation. The King had not positively refused to gratify the minister of that congregation; who with great professions of duty had besought him to do them that honour...

The Lord Jermyn... wondered, he said, why it should be opposed by any man; since he did not wish that his Majesty would discontinue his own devotions, according to the course he had always observed, nor propose that he should often repair thither, but only sometimes, at least

1 Durel, in 1662, published an interesting View of the Government and Public Worship of God in the Reformed Churches beyond the Seas, to show that they did not disapprove of episcopacy or the prayerbook. 


\section{The Restoration Period}

once, to show that he did look upon them as of the same religion with him; which the church of England had always acknowledged; and that it had been an instruction to the English ambassadors that they should keep a good correspondence with those of the religion and frequently resort to divine service at Charenton, where they had always a pew kept for them.

The Chancellor of the Exchequer [Hyde himself] dissuaded his Majesty from going thither, with equal earnestness; told him that whatever countenance or favour the crown or church of England had heretofore shewn to those congregations, it was in a time when they carried themselves with modesty and duty towards both, and when they professed great duty to the King, and much reverence to that church, lamenting themselves that it was not in their power, by the opposition of the state, to make their reformation so perfect as it was in England : and by this kind of behaviour they had indeed received the protection and countenance from England, as if they were of the same religion.... Whatever it was, that people now had undeserved it from the King ; for as soon as the troubles begun, the Hugonots of France...had publicly and industriously justified the rebellion, and prayed for the good success of it ; and their synod itself had in such a manner inveighed against the church of England, that they, upon the matter, professed themselves to be of another religion and inveighed against episcopacy, as if it were inconsistent with the protestant religion.... [He] told the King " that... his going to Charenton could not be without this effect, that it would be concluded everywhere that his Majesty thought the one or the other profession to be indifferent ; which would be one of the most deadly wounds to the church of England that it had yet suffered ${ }^{1 . "}$

This language is not very easy to reconcile with the views expressed in an earlier part of the History,

1 History of the Rebellion (ed. I704), vol. III. pp. 344 foll. 
where Clarendon describes the growing alienation between the English church and the foreign protestants. He dwells on the dislike which was felt by the authorities towards the foreign congregations in England:

Some few years before these troubles, when the power of the churchmen grew more transcendent,... the bishops grew jealous that the countenancing another discipline of the church here by order of the state (for those foreign congregations were governed by a presbytery according to the custom and constitution of those parts of which they had been natives : the French, Dutch, and Walloons had the free use of several churches according to their own discipline) would at least diminish the reputation and dignity of the episcopal government, and give some countenance to the factious and schismatical party in England to hope for such a toleration ${ }^{\mathbf{1}}$.

Their treatment of the congregations was of course known abroad, and produced resentment. But the home government and its ecclesiastical advisers went further:

And that this might be sure to look like more than what was necessary to the civil policy of the kingdom, whereas in all former times the ambassadors and all foreign ministers of state, employed from England into any parts where the reformed religion was exercised, frequented their churches, gave all possible countenance to their profession, and held correspondence with the most active and powerful persons of that relation, and particularly the Ambassador Leiger at Paris had diligently and constantly frequented the church at Charenton, and held a fair intercourse with those of that religion throughout the kingdom [for the sake of

${ }^{1}$ History of the Rebellion, vol. Ir. p. 73. 


\section{The Restoration Period}

political advantages], the contrary to this was now with great industry practised, and some advertisements, if not instructions, given to the ambassadors there, "to forbear any extraordinary commerce with the men of that profession." And the Lord Scudamore, who was the last ordinary ambassador there before the beginning of this parliament, whether by the inclination of his own nature, or by advice from others, not only declined going to Charenton, but furnished his own chapel in his house with such ornaments (as candles upon the communion table and the like) as gave great offence and umbrage to those of the reformation there, who had not seen the like; besides that he was careful to publish upon all occasions by himself and those who had the nearest relation to him, "that the church of England looked not on the Hugonots as a part of their communion"; which was likewise too much and too industriously discoursed at home ${ }^{1}$.

Clarendon does not admit that there was any "Romeward drift" (as it has been called) in the men who took this line; but for purely political reasons he deplores it.

They of the church of England who committed the greatest errors this way had undoubtedly not the least thoughts of making alterations in it towards the countenancing of popery, as hath been uncharitably conceived : but (having too just cause given them to dislike the passion and licence that was taken by some persons in the reformed churches under the notion of conscience and religion to the disturbance of the peace of kingdoms) unskilfully believed that the total declining the interest of that party, where it exceeded the necessary bounds of reformation, would make this church of England looked upon with more reverence.... [None of them discerned] the true and substantial grounds of that policy upon which that good correspondence had been founded which they were now about to change: and

1 History of the Rebellion, vol. II. p. 74. 
so the church of England, not giving the same countenance to those of the religion in foreign parts, which it had formerly done, no sooner was discerned to be under a cloud at home, but those of the religion abroad were glad of the occasion to publish their malice against her, and to enter into the same conspiracy against the crown, without which they could have done little to hurt the church ${ }^{\mathbf{1}}$.

The man whom Clarendon selected to send over to England in I66o, to negotiate with the presbyterian party in view of the King's return, was George Morley, soon to be Bishop of Worcester, and afterwards of Winchester. Morley, at an earlier time the friend of Falkland, and later of Izaak Walton, had refused to worship with the French protestants,-partly because of their attitude towards English politics. $\mathrm{He}$ had the reputation of being no extremist. He was ready to advocate a kind of "reduced" episcopacy if he could get nothing better, and most anxious to prevent the other clergy from using indiscreet language ${ }^{2}$.

I foresee, he wrote to Clarendon on May 4, r66o, the main difficulty will be touching their ordinations by presbyters without bishops, which we cannot acknowledge to be lawful, nor will they, I am afraid, be brought to acknowledge to be unlawful, and much less to be mere nullities. In this case I have thought of two expedients; the one that no notice be taken whether there have been any such ordinations or no ; the other, that there may be an hypothetical reordination, by bishops, of such as were so ordained, which reordination, as it will be a provision against the nullity of such ordinations, so it will not conclude them to be nullities,

1 History of the Rebellion, vol. II. pp. 74 foll.

2 Clarendon State Papers, vol. III. p. 727. 


\section{The Restoration Period}

but only irregular and uncertain. And this is much the better salvo of the two, if they can be brought to it ${ }^{1}$.

What Morley means by his first "expedient" is plain. It was to accept the men just as they were without asking any questions. If right provisions were made for all future ordinations, it was possible to argue that this generation of irregularly ordained ministers might be allowed gradually to die out, without being ousted from their benefices. But this " expedient" was rejected by the English laity who framed and passed the Act of Uniformity.

The passage in Clarendon's Life has been often quoted, in which he describes the result which was finally reached, and the new departure which, in his opinion, it created.

The Act of Uniformity depended long, and took up much debate in both houses. In the house of peers, where the act first began, there were many things inserted which had not been contained in the former act of uniformity, and so seemed to carry somewhat of novelty in them. It admitted " no person to have any cure of souls, or any ecclesiastical dignity, in the church of England, but such who had been or should be ordained priest or deacon by some bishop, that is, who had not episcopal ordination; excepting only the ministers or pastors of the French and Dutch churches in London and other places allowed by the King, who should enjoy the privileges they had."

This was new; for there had been many, and at present there were some, who possessed benefices with cure of souls, and other ecclesiastical promotions, who had never received orders but in France or in Holland; and these men must now receive new ordination, which had been alwavs held unlawful in the church, or by this act of parliament must.

1 Clarendon State Papers, vol. III. p. 738.

M. 
be deprived of their livelihood, which they enjoyed in the most flourishing and peaceable time of the church. And therefore it was said [Clarendon does not say by whom] that this had not been the opinion of the church of England, and that it would lay a great reproach upon all other protestant churches who had no bishops, as if they had no ministers, and consequently were no churches; for that it was well known the church of England did not allow reordination, as the ancient church never admitted it, insomuch as if any priest of the church of Rome renounces the communion thereof, his ordination is not questioned, but he is as capable of any preferment in this church as if he had been ordained in it. And therefore the not admitting the ministers of other protestants to have the same privilege can proceed from no other ground than that they looked not upon them as ministers, having no ordination; which is a judgment the church of England had not ever owned, and that it would be very imprudent to do it now.

The issue could hardly be stated more clearly; nor is the reply ambiguous.

To this it was answered, that the church of England judged none but her own children, nor did determine that other protestant churches were without ordination. It is a thing without her cognisance; and most of the learned men of those churches had made necessity the chief pillar to support that ordination of theirs. That necessity cannot be pleaded here, where ordination is given according to the unquestionable practice of the church of Christ. If they who pretend [i.e. allege] foreign ordination are his Majesty's subjects, they have no excuse of necessity, for they might in all times have received episcopal ordination, and so they did upon the matter renounce their own church. If they are strangers, and pretend to [i.e. are candidates for] preferment in this church, they ought to conform and to be subject to the laws of the kingdom, which concern only those who desire to live under the protection thereof. For the 


\section{The Restoration Period}

argument of reordination, there is no such thing required. Rebaptization is not allowed in or by any church ; yet in all churches, where it is doubted as it may be often with very good reason, whether the person hath been baptized or no, or if it hath been baptized by a midwife or lay person, without determining the validity or invalidity of such baptism there is an hypothetical form, If thou hast not been already baptized, I do baptize, etc. So in this case of ordination, the form may be the same, If thou hast not been already ordained, then $I$ do ordain etc. If his former ordination were good, this is void; if the other was invalid or defective, he hath reason to be glad that it be thus supplied.

The historian concludes :

After much debate, that clause remained still in the act ; and very many who had received presbyterian orders in the late times came very willingly to be ordained in the manner aforesaid by a bishop, and very few chose to quit or lose a parsonage or vicarage of any value upon that scruple.

When we turn from the men of action to the theologians of the restoration, it will be not unnatural to begin with Thorndike, one of the most remarkable writers whom the church of England has produced.

Obscure and unpleasant as his style is, he conducts his investigations in a quite original way, and arrives sometimes at results which would not be expected from a writer so severely catholic in his principles. Usher himself, or Baxter either, is not more decided in his views on the primitive " moderation" of episcopacy. The primitive bishops were "heads of presbyteries ${ }^{2}$." The government of the churches

1 Continuation of the Life (ed. I759), pp. I 52 foll.

2 Primitive Government of Churches in Works (ed. I844), vol. I. p. 3o. The book was published in $\mathrm{I} 64 \mathrm{I}$. 
passed from the apostles to the bishop and his presbytery in common. The Ephesian elders, whom St Paul addressed at Miletus, were not by Timothy's arrival to be their bishop discharged from the supervision of the flock entrusted to them before. The instructions given in the Pastoral Epistles were not for Timothy alone, but for his presbytery with him. If the bible does not say much on this point, it must be remembered, Thorndike says, that for the most part the New Testament writings are earlier than the appointment of bishops, and date from the time when the apostles themselves were executing the episcopal office.

From this it follows, in Thorndike's opinion, that the power of ordination rested originally in the same hands as the general government of the churches; that is, in the apostle and the presbytery before there were bishops,-in the bishop and the presbytery in conmon afterwards. This soon came to be altered :

Now of all parts of the office common to bishop and presbyters, this of ordination is that which the bishop first began to exercise alone; so that with St Chry'sostom and St Jerome it is taken in a manner for granted that it was to be done by him alone.... In which, nevertheless... if we take not our marks amiss, we shall find argument enough, at least at the beginning, for the concurrence of presbyters with him in making of presbyters and other inferior orders. In the first place, those general passages of the fathers wherein is witnessed that the presbytery was a bench assistant to the bishop, without advice whereof nothing of moment was done, must needs be drawn into consequence to argue that it had effect in a particular of this weight. Then the ordination of 
Timothy by imposition of hands of the presbytery ${ }^{1}$ will prove no less within compass of the scripture.... Neither are the arguments of this interest quite worn out of the practice of the church, either in the point of nominating the persons or that of imposing hands.... This [imposition of hands] is, and was, and ought to be, in sign of their consent to what is done ${ }^{2}$.

The argument might seem to be in favour of presbyterianism, but that was not at all Thorndike's meaning. If bishops were not to act without their presbyters, still less did he think that presbyters could act, or had ever rightly acted, without their bishops :

He that aimeth at the primitive form, and that which cometh nearest the institution of our Lord and his apostles, must not think of destroying bishops, but of restoring their presbyteries. Were it but a human ordinance of yesterday, ... let me be bold to say that if Aerius withdraw his submission to it, he must come within Epiphanius' list of heretics. ... Of this crime my earnest desire is that those which have separated themselves from this church of England upon this quarrel of government by bishops... may stand acquitted; though how they will acquit themselves of it, I cannot yet perceive.... Be it pardonable for our neighbours and brethren of the reformed churches abroad to have overseen the succession of the apostles, because they could not discern it as they found it blended with such abundance of accessories, especially in the persons of men that hated to be reformed ; but among us there hath been time to plead the right to the quick ; and... we have heard little or nothing as yet of new reasons to quell the cause with.... The honour and esteem, which the learned of the reformed churches abroad have professed of the state of our [British] churches, and our charity in excusing the necessities of theirs and acknowledging

1 Thorndike forgets that the words are not $\delta \dot{a} a$ but $\mu \epsilon \tau \dot{a} \dot{\epsilon} \pi \imath \theta^{\prime} \dot{\epsilon} \sigma \epsilon \omega s$.

${ }^{2}$ Works (ed. 1844), vol. I. pp. 74-77. 
the efficacy of the ministry which they use, will be sufficient through God's goodness to actuate the correspondence we desire to preserve with them, without those innovations which were never required at our hands to such purpose'.

Thorndike ends this book with an earnest plea for the restoration of presbyteries to act with the bishops.

In a later work, on the Right of the Church in a Christian State (I649), Thorndike propounds the view that in some cases at least the consent of the churchthat is, of the single or diocesan church-might make a priest without ordination. The argument is this :

I suppose no man will deny that all ordinations in schism are mere nullities, though made by persons rightly ordained, because against the unity of the church [a somewhat startling assertion of Cyprianic principles]. And yet we find such ordinations made valid by the mere decree of the church, without ordaining anew. [Instances are mentioned.]. . . For the only reason why some things, though they be ill done, yet are to stand good, is because the power that doth them extendeth to them, but is ill used. [This is not the case, he says, in schism: the power is not there.] So when the power is usurped, as in all schism, or when that is done which the law makes void, it can be to no effect. Therefore when the act of schism [i.e. the act of ordination done by those in schism] is made valid, it is manifest that the order of bishop and presbyter is conferred in point of right by the mere consent of the church, which by the precedent ordination was conferred only in point of fact, being a mere nullity in point of right ${ }^{2}$.

To the objection that there is no precept in the scripture that all churches should be governed by

1 Works, vol. 1. pp. 90-94.

2'Works, vol. I. (part II.) p. 50 I. 
bishops, and that many things ordained by the apostles have ceased to be binding on the church, Thorndike answers that

we must confess that as there are precepts in the scripture that oblige not, so there are many things, not set down in the scripture in the form of precepts, that oblige. [Examples are given.] What means is there then to end everlasting difficulties? Surely the same that there is to understand all positive laws that ever were. For if the ancient interruption of the practice of any law secure the church [i.e. demonstrate clearly to it] that it was not given to all times and places, sure that which is not mentioned as a precept, and yet has been always in practice without interruption, as it was in force afore it was mentioned, so was intended to oblige not by the mention, but by the act that first established it, evidenced by practicé. Which if it be so, then is there no power on earth to abolish the order of bishops, having been in force in all churches ever since the apostles ${ }^{1}$.

A cry that is frequently raised in our time was not unheard in Thorndike's, that the greatest obstacle to the reunion of reformed Christianity is the episcopate. Thorndike admits that in spite of its ancient sanctions there are other things to be considered besides the preservation of episcopacy, but will not admit that this is any reason for its abolition :

Seeing then that it is agreed upon by all that profess the reformation, that many and divers things ordained by our Lord and his apostles, whether to be believed or to be practised in the church, were so abolished by injury of time that it was requisite they should be restored, though against the will of those that bore that power which the apostles

1 Works vol. I. (part I1.) pp. 505-507. 
appointed necessary to conclude the church [i.e. to keep it together]; it followeth that the necessity of reformation inferreth-not the abolishing of the succession of the apostles, but-that more laws of our Lord and his apostles, and of more moment, were preferred before it where it could not regularly be preserved; which, when it may be preserved, is to be so far preserved before all designs which may seem to human judgment expedient to the advancement of Christianity, that whosoever shall endeavour without such cause to destroy the power derived from the apostles by conferring it upon those that succeed them not in it-and much more whosoever shall do it to introduce laws contrary to the ordinance of the apostles-shall be thereby guilty of the horrible crime of schism ${ }^{1}$.

Thorndike applies what he has said to the continental reformation:

I will not leave this point without saying something of their case that have reformed the church without authority of bishops; that have abolished the order and vested their power... upon presbyteries or whatsoever besides; which to decline here might make men conceive that I have a better or worse opinion of them than indeed I have ${ }^{2}$.

He supposes the case of a Christian people destitute of bishops. They are, he thinks, bound in the first place " to receive pastors from them that are able to found and erect churches, and to unite them to the communion of the whole church," which is what the episcopate does. But supposing this to be impossible?

Seeing then [that] edification is the end for which the society of the church subsisteth, and all pastors and officers ordained as a means to procure it, as it is sacrilege to seek the end without the means when both are possible, so I

1 Works, vol. I. pp. 59 I foll.

2 Ibid. p. 603. 
conceive it would be sacrilege not to seek the end without the means when both are not. Now it is manifestly possible that the edification of the church may be procured effectually by those that receive not their power or their office from persons endowed with it themselves afore... . The consequence of all this is plain enough. The resolution of Gulielmus Antissiodorensis among the school doctors is well known and approved; - that the order of bishops, in case of necessity, may be propagated by presbyters, [even] supposing that they never received power to do such an act from them that had it. This reason makes us bold to resolve further, that, in the case which is put, Christian people may appoint [to] themselves bishops, presbyters, and deacons,... and that upon these terms they ought to be acknowledged by the rest of the church, whensoever there is opportunity of communicating with the same, provided that they...submit to such laws... as the rest of the church hath provided... according as the part is to submit to the determination of the whole: and that this acknowledgment of them would be effectual instead of solemn ordination by imposition of hands of persons endowed with that power which is intended to be conveyed by the same. Whereby I make not personal succession to be no precept of God-which if it were not, then no schism were necessarily a sin, and all that can be said of the society of the church would be a fable-but commanded in order to another [precept], of living in the society of a church, and therefore not binding when both are not possible but the chief is ${ }^{1}$.

Thorndike's view, therefore, of the foreign reformers is that they had some degree of justification for what they did. "It seems " that they could not get properly consecrated bishops without abandoning principles still more important. "It seems" that their leaders, though not bishops, were yet " of some

1 Works, vol. 1. pp. 604 foll. 
order in the church." But they ought, he thinks, to have created bishops of their own; instead of which they persuaded themselves that the office itself was a corruption :

Which notwithstanding, seeing they profess all that is necessary to the salvation of all Christians, either in point of faith or manners; seeing, as to the public order of the church, they intended and desired and sought to restore that which to their best understanding came from the institution of our Lord and his apostles ; they cannot easily be condemned to have forfeited the being of a church, out of which there is no salvation, by this or other mistakes of like consequence, of them that consider the abuses from whence they departed.... As there is no society of men, wherein a particular member can prevail to settle such laws and such order as are properest to the end of it, so must he live and die out of communion with the church, that stays till he find a church that maintains all that was instituted by our Lord and his apostles. Wherefore though that which they have done contrary to the apostles' order cannot be justified, yet there is a reasonable presumption that God excuses it, being no part of that which he hath commanded all to believe to salvation, or which he hath commanded particular men to do ${ }^{1}$.

But Thorndike's readiness to recognise the foreign reformed churches makes only the more striking his condemnation of the two great sects which at the time of his writing had captured England by the sword. Of the presbyterians, after reckoning up the points of their error, he says :

${ }^{1}$ Works, vol. I. p. 607. Cp. p. 619, where Thorndike will not "balk the fruit of the divine right of bishops," which is a thing "which no man may lawfully destroy, though not [one] which, being destroyed, voideth the being of a church, if it can be done without schism." 


\section{The Restoration Period}

The endeavouring to establish these presbyteries is an act of schism, which particular Christians, though they never by any express act of their own tied themselves to be subject to bishops, are nevertheless bound not to communicate in, because they are bound upon their salvation to maintain the unity of the church, and the unity of the church established upon those laws whereof the succession of bishops is one ${ }^{1}$.

The method of the independents was, in Thorndike's eyes, "more suitable to Christianity" than that of the presbyterians: it relied less upon state aid, and had a worthier conception of the freedom and spirituality of the churches. But he adds :

I intend not hereby to grant that it is a rightful title upon which those of the congregations [i.e. the independents] separate from the church of England. For as men cannot make themselves Christians, but the doing of it must presuppose a church... - because our Lord hath required of those that will be saved, not only to believe his gospel, but also to profess Christianity, and this profession to be consigned in the hands of those whom he trusteth with the conduct of his church...-so the continuance in the communion of the church, presupposing an acknowledgment of the Christianity professed therein to contain nothing destructive to salvation, professeth an obligation of acknowledging the governors thereof ${ }^{2}$.

This obligation would only be avoidable if these governors appear to " defeat" Christian people

of the benefit of such laws, given the church by our Lord and his apostles, as appear to be of greater consequence to the service of God, for which the society of the church subsists, than the personal succession of governors, and the unity of the church ${ }^{3}$.

1 Works, vol. I. p. 62I.

2 Ibid. p. 623. 3 Ibid. 
Finally this powerful, if somewhat unpractical, thinker suggests, as the only means that he can think of for restoring unity in England, the holding of a great conference, in which it might

be discerned how far the church of England may abate of the right, which is denied only by force, for so good a purpose as to reconcile unto it those who may otherwise fall into churches in name, but schisms indeed ${ }^{1}$.

As the issue of such a conference

it will be lawful for those in whom rests the succession of the apostles, and all claiming under them, to consent to estate the ecclesiastical power and the ministry of ecclesiastical offices upon persons to be agreed upon according to terms agreed: and this consent as effectual to reunite the church, as ever anciently schisms were lawfully restored to the church, by admitting bishops, presbyters, deacons, and people, to communicate in their own ranks, and making good all acts done in separation, by subsequent consent, not as to God, but as to the church ${ }^{2}$.

In the meantime, until such public reconciliation takes place, Thorndike has no doubt about the duty of the members of the suffering church.

Let me admonish those infinite numbers of Christian souls that sigh and groan after the unity of the church, what means God shows them to discharge the conscience of good Christians to him.

The temporal laws of the state have suspended the office " of those in whom the succession of the apostles is vested, and the clergy claiming under them." But the men still exist, and " that general law of Christianity" remains,

1 Works, vol. I. p. 63 I.

2 Ibid. p. 633. 


\section{The Restoration Period}

of sticking to all that the church originally, always, every where, hath professed and used. From them [the bishops and episcopal clergy] let them seek the communion of the church.... Neither let them ever think themselves necessitated to communicate with schism, while the law which is the source of all laws, and the persons which are the seed of all public persons of the church, continue ${ }^{1}$.

In 1659 , just when churchmen in general were beginning to see daylight, the great solitary student published his immense Epilogue to the Tragedy of the Church of England, in which he felt himself at liberty to criticize in some respects the position which that church had taken up. He was no more drawn to Romanism than before, but Thorndike was a catholic first, and an Anglican afterwards ; but yet a catholic because an Anglican.

I from my nonage, he says in the "Preface to all Christian Readers," had embraced the church of England, and attained the order of priesthood in it, upon the supposition that it was a true church and salvation to be had in it and by it; owning nevertheless-as the church of England did own - the church of Rome for a church, in which salvation, though more difficult, yet might be had and obtained. That there is no such thing as a church by God's law, in the nature of a body,-which this state of religion [i.e. the mixture of presbyterianism and independency then established] requireth-is opposite to an article of my creed, who always thought myself a member of such a body by being of the church of England ${ }^{2}$.

The one advantage which Thorndike saw in the divisions of Christendom was that they cast the

1 Works, vol. I. pp. 633 foll.

2 Ibid. vol. II. p. 4. 
Christian back upon first principles, and set him free to state those principles in a way which he would have scrupled to use in happier times, for fear of disturbing the peace.

For unity in the church is of so great advantage to the service of God... that it ought to overshadow and cover very great imperfections in the laws of the church, all laws being subject to [imperfections]; especially, seeing I maintain that the church by divine institution is in point of right one visible body, consisting in the communion of all Christians in the offices of God's service, and ought by human administration in point of fact to be the same. For the unity of so great a body will not allow that the terms should be strict or nice upon which the communion thereof standeth, but obligeth all that love the general good of it to pass by even those imperfections in the laws of it which are visible, if [i.e. so long as] they are not pernicious. But where this unity is once broken in pieces and destroyed, and palliating cures are out of date, the offence which is taken at showing the true cure is imputable to them that cause the fraction, not to him that would see it restored. For what disease was ever cured without offending the body that had it ? The cause of episcopacy and of the service ${ }^{1}$ is the cause of the whole church, and the maintenance thereof inferreth [i.e. involves] the maintenance of whatsoever is catholic ${ }^{2}$.

He proceeds to the application :

Owning therefore my obligation to the whole church,notwithstanding my obligation to the church of England,I have prescribed the consent thereof [i.e. of the whole church] for a boundary to all interpretation of scripture, all reformation in the church, referring my opinion, in point of fact, what is catholic, to them who by their title are bound

1 Thorndike has said above that episcopacy and the Prayer-Book were the whole cause of the rising against the church.

${ }^{2}$ Works, vol. II. p. 6. 
to acknowledge that whatsoever is catholic ought to take place [i.e. to the common consent of all who claim to be catholics]. While all English people by the laws of the church of England had sufficient... means of salvation ministered to them, it had been a fault to acknowledge a fault which it was more mischief to mend than to bear with. But when the unity that is lost may as well be obtained by the primitive truth and order of the catholic church as by that which served the turn in the church of England...I should offend good Christians to think they will stand offended at it ${ }^{1}$.

Thus, not without a touch of humour, Thorndike asserts a right of revision for the Anglican, in the light of a better understood catholicism. It would take us too far from our immediate purpose, to follow him in his interesting discussion of the relations between the particular church and the universal, and between both and the individual Christian-the Christian who is not at liberty to form churches at pleasure, on arbitrary grounds, but is bound to maintain unity with the fellow Christians among whom God has placed him, and yet retains his interior freedom with regard to the rules with which he conforms, and the duty of professing what he believes to be true ${ }^{2}$.

When the restoration came about, Thorndike endeavoured to summarize the doctrine of the Epilogue in his Due Way of Composing Differences (I66o). He reiterates as the ground of all else the article of " one catholic church."

1 Works, vol. II. p. 7.

2 Ibid. pp. 395 foll., 378 foll., 474 foll. There is a vigorous exposition of the constitution of the church in vol. IV. pp. 363-370. 
For either it signifies nothing, or it signifies that God hath founded one visible church; that is, that he hath obliged all churches (and all Christians, of whom all churches consist) to hold visible communion with the whole church in the visible offices of God's public service. And therefore I am satisfied that the differences upon which we are divided cannot be justly settled upon any terms which any part of the whole church shall have just cause to refuse as inconsistent with the unity of the whole church. For in that case we must needs become schismatics, by settling ourselves upon such laws, under which any church may refuse to communicate with us, because it is bound to communicate with the whole church ${ }^{1}$.

No power of the church can make anything " a part of the common Christianity" which was not so from the beginning; but, on the other hand,

we shall justly be chargeable with the crime of heresy, if we admit them to our communion who openly disclaim the faith of the whole church, or any part of [that faith]. For those are justly counted heretics...that communicate with those who profess heresy, though no heretics as to God, not believing it [i.e. if they do not believe it] themselves. But the unity of all parts being subordinate...to the unity of the whole, we shall justly be chargeable with the crime of schism, if we seek unity within ourselves by abrogating the laws of the whole, as [if we were] not obliged to hold communion with it ${ }^{2}$.

Thorndike sorrowfully admits that we cannot at present " expect any reason from the church of Rome," to help in restoring the unity of the church on righteous terms; yet he will not agree to " that madness which hath had a hand in all our miseries,"

1 Works, vol. v. p. 27.

2 Ibid. p. 28. 


\section{The Restoration Period}

of thinking that reformation consists in going as far as possible from Rome.

The unity of the church is of such consequence to the salvation of all Christians, that no excess on one side can cause the other to increase the distance, but they shall be [i.e. without being] answerable for the souls that perish by the means of it ${ }^{1}$.

Thorndike sternly demands that people returning into the church from various forms of error should make an acknowledgement of the error. If they will not do this, he thinks it justifiable that the secular power should "grant them the exercise of their religion, in private places of their own providing"; only the same toleration should be given to papists as to others. Even presbyterians are not to be exempted from the necessity of renouncing presbyterianism, though Thorndike leaves it to his superiors to determine what form should be observed in receiving into the ministry of the church the presbyterian ministers, whose ordinations are " mere nullities in themselves ${ }^{2}$."

The argument of the presbyterian party was that the abolition of episcopacy would assimilate the church of England to the other reformed churches. In an interesting passage Thorndike contests this view. There are, he says, "four forms of reformation extant." One is according to Luther, a second according to Calvin, the third is that of the church of England; the fourth, with which Thorndike was deeply occupied at the moment, was " first in time," but

1 Works, vol. v. p. 3 .

${ }^{2}$ Ibid.pp. 42 foll.

M. 
" least known and protected by no sovereign." It was the reformation " of the Union in Bohemia." When the presbyterian party asked for reform, they meant reform of the Calvinist type: Thorndike asks "why we are to leave Luther for Calvin?" $\mathrm{He}$ finds Melanchthon " the better learned and the more Christian spirit."

But the church of England, which in divers points differeth from both,- - why should it be thought to follow either for any reason but as either agrees with the catholic church? And for that reason I prefer the Unity of Bohemia before both ${ }^{1}$.

Thorndike is not prepared to approve of everything that he had read about the Unity : in particular he thought that they had been unnecessarily censorious towards the Greek church. Nevertheless, they had had an eye to the Vincentian canon of catholicity, and

sent all over the world to inform themselves of a visible succession of bishops, whose profession was such that they might derive the ordination of bishops for their churches from their hands.... Hearing that the Waldenses lived in Austria under bishops deriving their succession from the time of Constantine, and therefore from the apostles, they sent them thither to be ordained... . Now I take not upon me to maintain the truth of that information concerning the succession of these bishops, whereupon they proceeded. But they being reasonably persuaded of it, and not knowing how to proceed otherwise, through a mistake or an exigent, which they could not overcome, and settling themselves upon an innocent presumption, why should the effect of these ordinations

1 Works, vol. v. p. 68. 
seem questionable? For under these bishops they have subsisted from that day to this ${ }^{1}$....

There was a good expedient in the ancient church, to refer things to God, which could not be decided without a breach in the church.... Let the difficulty of procuring ordinations and having bishops render them [the foreign non-episcopal churches] excusable to God. [But] those that are ordained by presbyters against bishops, on purpose to set up altar against altar, how can we count them ordained, refusing the concurrence of the church to their ordinations? They that would tie us to comply with this reformation are first to show us that the Unity of Bohemia is no part of it, and that their reformation is not to be preferred either before that of Luther or that of Calvin. For can we acknowledge the ordinations of presbyters against their bishops, and not condemn them that sought all over the world for bishops to ordain them bishops, that the bishops so ordained might ordain them presbyters ${ }^{2}$ ?

Thorndike went further than others in the denial of all validity to the ordinations and the eucharists of schismatics, and used language about them derived from Cyprian in his severest mood, but from his lonely tower he had a wide outlook upon the state of Christendom.

Another renowned churchman, John Gauden, still calling himself Dean of Bocking, put forth his views on the situation in I659, the year of Thorndike's Epilogue. His book was the 'I $\epsilon \rho a ̀$ $\Delta a ́ k \rho v a$, The Tears, Sighs, Complaints and Prayers of the Church of England. The preface is an address " to my

1 Works, vol. v. p. 62. It is curious that Thorndike, like others of his time, was unaware how matters stood in the church of Sweden. Laud knew; but few besides.

${ }^{2}$ Ibid. p. 63. 
honoured and beloved countrymen, persons of true honour, piety, and prudence." To them he says that he would keep silence in the evil time,

if I had not many and great stimulations...to give what further constant and comely proofs I may to this and after ages of my zeal for God, of my love to my Saviour, of my communion with his catholic church, of my particular respect to this noble part of it, the church of England ; and in this, of my due observance to my reverend fathers and beloved brethren, the godly bishops and orderly presbyters of this church ; yet lastly of my charitable ambition to heap coals of fire (not scorching and consuming, but melting and refining) even upon the heads of those who still profess to be remorseless enemies to my calling and to the whole church of England: who seem to me as if they sought totally to debase the clergy of England, yea utterly to destroy the ancient catholic order and government, succession and authority, of the evangelical ministry in this reformed church; while they endeavour to remove able, ordained, and authoritative teachers into corners, and to obtrude I know not what voluntiers, new and exotic intruders into that holy function ${ }^{1}$.

Gauden's book opens with an emblem. It is a tree, whose branches are the different churches proceeding from Christ, the root and stem. He explains the emblem.

First, most people, learned and unlearned, were heretofore possessed with the catholic use and approbation of episcopacy as ubique, semper, et ab omnibus, ever and only used in this and all other churches, from the first planting of Christianity. After this, many weaker Christians came to be dispossessed of their former persuasions by the violent obtrusions of such a presbytery as challengeth church-

1 Tears, Sighs, etc., p. I5. 


\section{The Restoration Period}

government, not in common with bishops, but wholly without them. This foreign plant, not taking any deep root in this English soil, was soon starved, and much supplanted by the insinuations of a newer way called Independency. At last many heretofore well-meaning Christians, finding such great authorities, even from Christ, pretended on all sides for these diversities... have by long, perplexed, and sharp disputes been brought to such doubtings as have betrayed them to strange indifferencies as to all ecclesiastical society and order, which is the very band of Christian religion ${ }^{1}$.

Gauden defines what he means by the church of England, " according to the good old style," employed e.g. by Jewel,-a name " more ancient, more honourable, and every way as proper, as the new style and title of the commonwealth of England."

By the name of the church of England it is not imputed or implied that we judge every particular person in this nation to be inwardly a good Christian or a true Israelite, that is, really sanctified or spiritually a member of Christ and his mystical body, the church catholic, invisible. No, we are not so rude understanders or uncritical speakers. But we plainly and charitably mean that part of mankind in this polity or nation, which having been called, baptized, and instructed by lawful ministers in the mysteries and duties of the gospel maketh a joint and public profession of the Christian faith and reformed religion in the name, and as the sense, of the whole nation; as it is grounded upon the holy scriptures, guided also and administered by that uniform order, one authority, and holy ministry, for worship and government, which according to the mind of Christ, the pattern of the apostles, and the practice of all primitive churches, hath been lawfully established by the wisdom and consent of all estates in this nation ${ }^{2}$.

1 Tears, Sighs, etc., p. 23.

2 Ibid. p. 24. 
Although the name of a church may be given to local congregations, it may also be applied to larger combinations :

It is most evident, by scripture dialect, by the wisdom of Christ's Spirit, by the apostolic prudence, and the subsequent practices of all famous churches... that the completeness and perfection of church polity... was never thought to be seated or circumscribed in every particular congregation of Christians... but it was placed in those great branches... which had in them the united power or authority, not only of many Christians, but of many congregations, in which were many godly people, many grave deacons, many venerable presbyters, and one eminent bishop or father, who continued in that presidential authority, to water, propagate, increase, preserve, and govern, in order, peace, and unity, those churches which the apostles had so planted.... In which, the... bishop so presided in the place, power, and spirit of the apostle (yea and of Jesus Christ) that no private Christian, no deacon, no presbyter, yea no particular congregation, might, as Ignatius and other ancients tell us, regularly do anything...without his respective authority, consent, and allowance. Yea all good Christians did ever make great conscience of dividing from the principal succession, seat, and pastor, who was the centre and conservator of that church union and government which was first settled by the apostles in primitive churches, and imitated by all others which grew up after them ${ }^{1}$.

Lamenting the loss-which had not then been made good-of Hooker's defence of episcopacy, Gauden says that the innovators

are likely to differ among themselves even till doomsday, unless they return, under some new name and disguised notion of moderators and superintendents, to what they

1 Tears, Sighs, etc., p. 28. 


\section{The Restoration Period}

have rashly deserted, the true pattern in the mount, that paternal, primitive, and catholic episcopacy, which was the centre and crown of the church's unity... which imports no more...than one grave and worthy presbyter duly chosen in the several dioceses and limits to be the chief ecclesiastic overseer and governour, succeeding in the managing of that ecclesiastical power and authority which... presbyters alone in parity or equality never did enjoy, and so never ought to exercise in the churches of Christ as to ordination and jurisdiction, no more than bishops regularly may without the counsel and assistance of presbyters. Which ancient order and eminent authority of primitive episcopacy, if neither right reason, nor the word of God, either in the Old or New Testament, did clearly set forth to us as best; if neither apostles at first, nor the primitive fathers after them; if neither church history, nor catholic custom, nor primitive antiquity, nor the approbation of the best reformed churches and divines; if all these did not commend it, as they evidently do...yet the late mad and sad extravagancies in religion do highly recommend it; yea the great want of it in England shows the great use, necessity, and excellency of it... I may add the votes of all sober and impartial Christians even now in England, who are grown so wise by their woes, as generally to wish for such episcopacy, whose restitution would be more welcome to the wiser and better sort of Christians in this nation than ever the removal of it was, or the medlies of presbytery and independency is like to be ${ }^{1}$.

Gauden complains that the innovators have adventured

to divide and destroy the office, honour, authority, the succession and derivation, yea the source and original of that sacred priesthood or evangelical ministry and mission, which was ever so highly esteemed... among all true Christians, as well knowing that its rise and institution was divine, from our Lord Jesus Christ, as sent of God his Father, who

1 Tears, Sighs, etc., pp. 84 foll. 
alone had authority to give the Word and Spirit, the mission and commission, the gifts and powers that are properly ministerial. Which as the blessed apostles first received immediately from Christ, so they duly and carefully derived them to their successors after such a method and manner as the primitive and catholic churches in all places and ages both perfectly knew and without question exactly followed, in their consecrating of bishops and ordaining of presbyters, with deacons, as the only ordinary ministers of Christ's church ${ }^{1}$.

In the fourth book of his treatise, Gauden weighs the good and the evil to be founded in the three competing religious systems, and naturally thinks that a constitutional episcopacy is the form which will divide men least :

Restore to people their liberty in some such way of choosing or at least approving their ministers and assenting to church censures, as may become them in reason and conscience. Restore to presbyters their privileges in such public counsel and concurrence with their bishops, as may become them. Lastly, restore to bishops that primitive precedency and catholic presidency, which they ever had among and above presbyters, both for that chief authority... which they ever had in ordaining of presbyters and deacons, also in exercising such ecclesiastical discipline and censures that nothing be done without them: I see no cause why any sober ministers and wise men should be unsatisfied, nor why they should longer stand at such distances and defiances, as if the liberties of Christian people, the privileges of Christian presbyters, and the dignity of Christian bishops were wholly inconsistent, whereas they are easily reconciled, and as a threefold cord may be so handsomely twined together that none should have cause to complain or be jealous ${ }^{2}$.

1 Tears, Sighs, etc., p. I6o.

2 Ibid. p. 453. 


\section{The Restoration Period}

Gauden will not take up the position of an extremist. He endeavours to put " true episcopacy" before its antagonists in a pleasing light :

I mean that primitive order and paternal residency [? presidency] which was universally acknowledged to be eminently in one president, as bishop or chief pastor over many presbyters in his diocese, after the pattern of the twelve apostles, who were by Christ's appointment above the seventy, and so their declared successors, as Timothy, Titus, Archippus, and those others who are called the angels of the seven Asian churches... for the settling. . . of church order... in such a way as clearly gives...to one man a paramount authority, as bishop or superior, both in ordination and jurisdiction $\mathbf{1}$.

\section{He appeals to their good sense :}

Do they in earnest think that no scripture, no word of God, old or new, no precepts and patterns of the apostles, no primitive practice, no true testimonies of fathers, councils, and credible historians do any way favour a right episcopacy...? 'Tis strange all should conspire thus to eject Christ from his kingdom and government, or to abuse the whole Christian world, from holy Polycarp, Polycrates, and Ignatius's days-all primitive bishops-yea from St John's days, and yet none detect or decry the fraud, none persevere in the first way, if it were, as is now pretended, independent or presbyterian ${ }^{2}$.

$\mathrm{He}$ is shocked at the way in which every petty presbytery now " spawns" ministers:

That these heteroclite or equivocal ordinations have of late been acted in England with much self-applause and popular parade by mere presbyters, I well understand; but quo jure, by what right from God or man...I could never

1 Tears, Sighs, etc., p. 459.

${ }^{2}$ Ibid. p. 462. 
yet see. Yea, I am sure no law of God or man heretofore was thought to give any such power to mere presbyters without, yea against, their lawful bishops: insomuch that many learned and sober men have much blamed...these presbyterian transactions for schismatical presumptions, these ordinations for disorderly usurpations, at least in such a church as England was, where there were, and still are, venerable bishops of the orthodox faith, reformed profession, and ancient constitution, willing and able to do their duty in the point of ordination.

Which in all ordinary cases appears to have been ever their peculiar right, specially derived to them as bishops from the apostles, through all successions of times and churches, without any interruption, except when some factious and insolent presbyters ventured to be extravagant and usurpant, whom all the learned fathers, venerable councils, and good Christians in the church everywhere condemned as most injurious, because usurping that authority which no apostle, no council, no bishop ever gave to any that were mere presbyters in their ordination and commission.... Nor is there, as far as I can perceive, any one place in scripture that by any precept or example invests either one or more simple presbyters with the power... of giving holy orders....All which were given to Timothy and Titus as chief bishops ${ }^{1}$.

Gauden is aware that popes are thought to have it in their power to authorise a presbyter to ordain ; "but in earnest," he says, "it is hard to judge whether popes or presbyters be most enemies to catholic bishops."

Possibly extraordinary cases may in time be their own excuses in such churches where bishops may be all dead or banished; or where such as are orthodox cannot be had;... but nothing can be pleaded that I yet see, no nor doth the candour and charity of Bishop Usher know how to excuse

1 Tears, Sighs, etc., p. 473. 
such presbyters from being schismatic and factious... who first cast off and forsake such bishops as are of the same faith and reformed profession, worthy and willing, able and ready, every way authorised by church and state to do their duty ${ }^{\mathbf{1}}$.

The book is wordy and full of repetitions, but it is a devout and pathetic statement of the church's wrongs, and a very moderate claim to have her considered in the readjustments which could not long be delayed.

The next theologian to be considered is Bramhall. No man ever breathed more calmly the atmosphere of an assured catholicism than Bramhall. Writing at Paris in poverty and exile in 1654 , he says what makes a catholic:

To sum up all that hath been said; whosoever doth preserve his obedience entire to the universal church, and its representative a general council, and to all his superiors in their due order, so far as by law he is obliged ; who holds an internal communion with all Christians, and an external communion so far as he can with a good conscience ; who approves no reformation but that which is made by lawful authority, upon sufficient grounds, with due moderation; who derives his Christianity by the uninterrupted line of apostolical succession; who contents himself with his proper place in the ecclesiastical body; who disbelieves nothing contained in holy scripture, and, if he holds any errors unwittingly and unwillingly, doth implicitly renounce them by his fuller and more firm adherence to that infallible rule ; who believeth and practiseth all those credenda and agenda, which the universal church spread over the face of the earth doth unanimously believe and practise as necessary to salvation, without condemning or censuring others of different judgment from himself in inferior questions, without obtruding

1 Tears, Sighs, etc., p. 474. 
his own opinions upon others as articles of faith; who is implicitly prepared to believe and do all other speculative and practical truths when they shall be revealed to him; and in sum qui sententiam diversae opinionis vinculo non praeponit unitatis... he may securely say, "My name is Christian, my surname is Catholic ${ }^{1 .}$ "

Bramhall does not waste many words in proving to his Romanist opponent that episcopacy is no mere accident of Anglicanism, though he is careful not to overstate the Anglican consensus on the subject:

As for our parts, we believe episcopacy to be at least an apostolical institution, approved by Christ himself in the Revelation, ordained in the infancy of Christianity as a remedy against schism ; and we bless God that we have a clear succession of $i^{2}$.

To the English or Scotch patrons of the Genevan discipline Bramhall wrote more fully at an earlier period, in I643. Sometimes he argues from the connexion between the episcopate and all English history :

That which the Observer [his opponent] saith of monarchy, that "our laws are locked and cabinetted in it in such manner that the wounding of the one is the bleeding of the other" ... is likewise true of episcopacy, that it is woven and riveted into the body of our law. Hear a witness beyond exception; " for the government of bishops, I for my part, not prejudging the precedents of other reformed churches, do hold it warranted by the word of God and by the practice of the ancient church in the better times, and much more convenient for kingdoms than parity of ministers or government by synods ${ }^{3} . "$

1 A Just Vindication in Works, ed. 1842, vol. I. p. III.

2 Ibid. p. 27 I.

3 Works, vol. III. p. 468. The quotation is from Bacon. 


\section{The Restoration Period}

Sometimes he argues from the antiquity and universality of the system :

Episcopacy... was universally received, without any opposition or so much as a question, throughout the whole Christian world, among all sorts of Christians, of what communion or profession soever they were, Grecian, Latin, Russian, Armenian, Abyssene, etc....And the Observer is challenged to name but one church, or so much as one poor village, throughout the whole world, from the days of the apostles till the year of Christ 1500 , that ever was governed without a bishop ${ }^{1}$.

Sometimes he takes the lowlier line, of greater security :

In a difference of ways, every pious and peaceable Christian, out of his discretion and care of his own salvation, will enquire which is the via tutissima, the safest way. Now the separatists themselves... do acknowledge that holy orders are truly, that is, validly, given by the ordination used in our church (I mean not such as either hold no outward calling to be needful, as the Anabaptists, or make the church a mere democracy, as the Independents); but on the other side a very great part of the Christian world, and among them many protestants, do allow no ordination to be right but from bishops.... And seeing there is required to the essence of a church, first, a pastor, secondly, a flock, thirdly, a subordination of this flock to this pastor; where we are not sure that there is right ordination, what assurance have we that there is a church ${ }^{2}$ ?

\section{Bramhall charitably guards his utterance :}

I write not this to prejudge our neighbour churches. I dare not limit the extraordinary operation of God's Spirit, where ordinary means are wanting, without the default of the persons. He gave his people manna for food whilst they

1 Works, vol. III. p. 469.

${ }^{2}$ Ibid. p. 475. 
were in the wilderness. Necessity is a strong plea. Many protestant churches lived under kings and bishops of another communion; others had particular reasons why they could not continue or introduce bishops. But it is not so with us. It was as wisely as charitably said of St Cyprian, "If any of my predecessors through ignorance or simplicity have not holden that which our Lord hath taught, the mercy of the Lord might pardon them." So, if any churches, through necessity, or ignorance, or newfangledness, or covetousness, or practice of some persons, have swerved from the apostolical rule or primitive institution, the Lord may pardon them, or supply the defect of man; but we must not therefore presume. It is charity to think well of our neighbours, and good divinity to look well to ourselves.... I do not make this way to be simply necessary, but only show what is safest, where so many Christians are of another mind. I know that there is great difference between a valid and a regular ordination, and what some choice divines do write of case of necessity; and for my part am apt to believe that God looks upon his people in mercy, with all their prejudices, and that there is a great latitude left to particular churches in the constitution of their ecclesiastical regiment, according to the exigence of time and place and persons, so as order and his own institution be observed ${ }^{1}$.

But Bramhall reminds his reader that we know by experience what bishops have done for us, and reminds him also - though this experience in his day was as yet but brief-that we have some reason to surmise what Christianity without bishops may come to :

If bishops had not been, God knows what churches, what religion, what sacraments, what Christ, we should have had at this day; and we may easily conjecture by that inundation of sects, which hath almost quite overwhelmed

1 Works, vol. III. pp. 475 foll. 


\section{The Restoration Period}

our poor church on a sudden, since the authority of bishops was suspended. The present condition of England doth plead more powerfully for bishops than all that have writ for episcopacy since the reformation of our church ${ }^{1}$.

The charitable tone in which Bramhall spoke to the anti-episcopalians in I643 sounds as clearly in his argument with the Romanists in 1654. He dwells with pleasure on the moderation of the English reformers :

They did not-we do not-deny the being of any church whatsoever, Roman or other, nor possibility of salvation in them, especially such as hold firmly the apostles' creed and the faith of the four first general councils; though their salvation be rendered much more difficult by human inventions and obstructions.... We do indeed require subscription to our articles, but it is only from them who are our own, not from strangers; nor yet of all our own, but only of those who seek to be initiated into holy orders and are to be admitted to some ecclesiastical preferment.... Neither are our articles penned with anathemas or curses against all those, even of our own, who do not receive them, but used only as a help or rule of unity among ourselves.... We presume not to censure others to be out of the pale of the church, but leave them to stand or fall to their own Master. We damn none for dissenting from us; we do not separate ourselves from other churches (unless they chase us away with their censures), but only from their errors.

He quotes the famous Canon 30 of $\mathrm{r} 603$, and adds:

So moderate are we towards all Christians, whether foreigners or domestics, whether whole churches or single persons ${ }^{2}$.

1 Works, vol. III. pp. 492 foll.

2 Ibid. vol. r. pp. 197 foll. 


\section{Then Bramhall proceeds :}

Secondly, as our separation is from their errors, not from their churches, so we do it with as much inward charity and moderation of our affections [i.e. control of our feelings], as we can possibly; willingly indeed in respect of their errors, and especially their tyrannical exactions and usurpations, but unwillingly and with reluctation in respect of their persons, and much more in respect of our common Saviour ; as if we were to depart from our father's or our brother's house, or rather from some contagious sickness wherewith it was infected : not forgetting to pray God daily to restore them to their former purity, that they and we may once again enjoy the comfort and contentment of one another's Christian society....

Thirdly, we do not arrogate to ourselves either a new church, or a new religion, or new holy orders; for then we must produce new miracles, new revelations, and new cloven tongues, for our justification. Our religion is the same it was, our church the same it was, our holy orders the same they were, in substance, differing only from what they were formerly, as a garden weeded from a garden unweeded, or a body purged from itself before it was purged. And therefore, as we presume not to make new articles of faith, much less to obtrude such innovations upon others, so we are not willing to receive them from others, or to mingle scholastical opinions with fundamental truths....

Lastly, we are ready in the preparation of our minds to believe and practise whatsoever the catholic church (even of this present age) doth universally and unanimously believe and practise. Quod apud multos unum invenitur, non est erratum, sed traditum ${ }^{1}$. And though it be neither lawful nor possible for us to hold actual communion with all sorts of Christians in all things wherein they vary both from the truth and one from another, yet even in those things we hold

1 Tertullian de Praescr. Haer. 28. 


\section{The Restoration Period}

a communion with them " in our desires," longing for their conversion and reunion with us in truth ${ }^{1}$.

With regard to the protestant churches in general, the church of England, in Bramhall's view, stands in some ways serenely apart :

[The Bishop of Chalcedon] changeth the subject of the question. My proposition was, that the church of England is free from schism. He ever and anon enlargeth it to all protestant churches; and what or how many churches he intendeth under that name and notion, I know not. Not that I censure any foreign churches, with whose laws and liberties I am not so well acquainted as with our own; but because I conceive the case of the church of England to be as clear as the sun at noonday, and am not willing for the present to have it perplexed with heterogeneous disputes. So often as he stumbleth upon this mistake, I must make bold to tell him, that he concludes not the contradictory ${ }^{2}$.

Like Crakanthorp, however, Bramhall was confronted with the accusation that the English church " joins in communion of sacraments and public prayers with schismatics, namely puritans and independents." and was therefore itself schismatic. It was a belated accusation, to say the least of it, in I654; but Bramhall patiently examines it, and his words are impassioned and weighty :

First, I deny his proposition. To communicate with heretics or schismatics in the same public assemblies, and to be present with them at the same divine offices, is not always heresy or schism, unless one communicate with them in their heretical or schismatical errors.... Have the English protestants.

1 Works, vol. I. pp. 199 foll. With regard to communion with the Eastern churches, see vol. II. p. 6I.

${ }^{2}$ Ibid. vol. II. p. 43.

M. 
[i.e. English churchmen] matriculated themselves into their congregational assemblies [i.e. those of the separatists] ? Have they justified the unwarrantable intrusion of themselves into sacred functions, without a lawful calling from Christ or his church? or their dispensing the greatest mysteries of religion with unwashen or, it may be, with bloody hands ? As for communicating with them in a schismatical liturgy, it is impossible ; they have no liturgy at all, but account it a stinting of the Spirit. And for the sacrament of the blessed body and blood of Christ, it is hard to say whether the use of it among them be rarer in most places, or the congregations thinner. But where the ministers are unqualified, or the form of administration is enormous in essentials, or sinful duties are obtruded as necessary parts of God's service, the English protestants know how to abstain from their communion...

Secondly, I deny his assumption,- that the church of England doth join in communion of sacraments and public prayers with any schismatics. What my thoughts are of those whom he turns [? terms] "puritans and independents," they will not much regard; nor doth it concern the cause in question. Many mushroom sects may be sprung up lately in the world, which I know not, and posterity will know them much less....I pass by them to that which is more material. If the church of England have joined in sacraments and public prayers with schismatics, let him show it out of her liturgy, or out of her articles, or out of her canons and constitutions, for by these she speaks unto us; or let him show that any genuine son of hers by her injunction, or direction, or approbation, did ever communicate with schismatics; or that her principles are such as do justify or warrant schism or lead men into a communion with schismatics; otherwise than thus a national church cannot communicate with schismatics. If to make canons and constitutions against schismatics be to cherish them; if to punish their conventicles and clandestine meetings be to frequent them; if to oblige all her sons who enter into holy 
orders, or are admitted to care of souls, to have no communion with them be to communicate with them; then the church of England is guilty of communicating with schismatics, or otherwise not ${ }^{1}$.

Bramhall does not deny that individual churchmen may have acted in the manner alleged. He does not conceal his opinion of them :

But I conceive that by the English church he intends particular persons of our communion. If so, then, by his favour, he deserts the cause, and alters the state of the question.... But who are these English protestants that communicate so freely with schismatics? Nay, he names none. We must take it upon his word. Are they peradventure the greater and the sounder part of the English church ? Neither the one nor the other. Let him look into our church and see how many of our principal divines have lost their dignities and benefices, only because they would not take a schismatical covenant.... Let him take a view of our universities and see how few of our old professors, or rectors and fellows of colleges, he finds left therein.... And if that hard weapon, necessity, have enforced any-perhaps with an intention to do good or prevent evil- to comply further than was meet, I do not doubt but they pray with Naaman, "The Lord be merciful to me in this thing." Suppose that some persons of the English communion do go sometimes to their meetings ; it may be out of conscience, to hear a sermon ; it may be out of curiosity, as men go to see Maygames, or monsters at fairs; it may be, that they may be the better able to confute them, as St Paul went into their heathenish temples at Athens and viewed their altars and read their inscriptions, yet without any approval of their idolatrous devotions; is this to communicate with schismatics? or what doth this concern the church of England ${ }^{2}$ ?

1 Works, vol. II. pp. 46-48.

2 Ibid. pp. 48 foll. 
The one ecclesiastical system, outside of England, for which Bramhall has no good word, is the religion set up in Scotland :

Let him not tell us, he says in 1656 , of the Scots' reformation, who have no better an opinion of it than it deserves ${ }^{1}$.

His Fair Warning to take heed of the Scottish Discipline was published at the Hague in I649; and when the date is taken into account, it is not to be much wondered at that Bramhall should speak with severe condemnation of the body which had brought England low and led to the killing of the king. He seems unable to bring himself to call it the church of Scotland; it is to him a kind of faction which for the time has mastered alike the churches of Scotland and of England.

If the Disciplinarians in Scotland, he breaks out, could rest contented to dote upon their own inventions, and magnify at home that Diana which themselves have canonized, I should leave them to the best schoolmistress, that is, experience, to feel where their shoe wrings them, and to purchase repentance. What have $I$ to do with the regulation of foreign churches, to burn mine own fingers with snuffing other men's candles? Let them stand or fall to their own Master... . But to see those very men, who plead so vehemently against all kinds of tyranny, attempt to obtrude their own dreams not only upon their fellow subjects, but upon their sovereign himself...yea, to compel foreign churches to dance after their pipe, to worship that counterfeit image which they feign to have fallen down from Jupiter, and by force of arms to turn their neighbours out of a possession of 
above fourteen hundred years, to make room for their Trojan horse of ecclesiastical discipline (a practice never justified in the world but either by the Turk or by the pope); this puts us upon the defensive part ${ }^{1}$.

He will not allow that they stand on the same footing as the foreign protestants :

I foresee that they will suggest that through their sides I seek to wound foreign churches. No: there is nothing which I shall convict them of here but I hope will be disavowed, though not by all protestant authors, yet by all the protestant churches in the world.... If it were not for this disciplinarian humour, which will admit no latitude in religion, but makes each nicety a fundamental and every private opinion an article of faith, which prefers particular errors before general truths, I doubt not but all reformed churches might easily be reconciled. Before these unhappy troubles in England, all protestants, both Lutherans and Calvinists, did give unto the English church the right hand of fellowship. The disciplinarians themselves, though they preferred their own church as more pure (else they were hard-hearted), yet they did not, they durst not, condemn the church of England, either as defective in any necessary point of Christian piety, or redundant in anything that might virtually or by consequence overthrow the foundation.... They themselves were then far from a party, or from making the calling of bishops to be antichristian ${ }^{2}$.

Bramhall's latest views upon the order which he adorned are contained in his Vindication of Grotius and the Episcopalians, composed in I659, against Baxter's insinuation that the great jurist had conspired with the bishops to lead the church back to communion with Rome. Baxter complained of the

1 Works, vol. III. p. 24 I.

2 Ibid. pp. 242, 243. 
change which had come over the divines of the church of England, and mentioned Bramhall as the signal example of the change. Bramhall will not hear of such a thing.

He would persuade us that there are two sorts of " episcopal divines " in England, the " old " and the " new," and that "there is much more difference between the old and the new than between " the old "and the presbyterians." O confidence, whither wilt thou! what is the power of prejudice and pride!... We are old episcopal divines, one and all... If they be "old episcopal divines," who maintain "the doctrine of the thirty nine articles and homilies " [as Baxter affirmed], then we are all " old episcopal divines ${ }^{1 . "}$

The new divines were charged with a more unfriendly attitude towards protestant churches than their predecessors had shown :

He showeth us the occasion;- " these that unchurch either all or most of the protestant churches, and maintain the Roman church and not theirs to be true, do call us to a moderate jealousy of them."...I wish he would...set down both his propositions expressly. His assumption is wanting, which should be this;- "But a considerable party of episcopal divines' in England do unchurch all or most of the protestant churches, and maintain the Roman church to be a true church, and them to be no true churches."

Bramhall can assent to neither proposition :

First, I cannot assent to his major proposition,-that all those who make an ordinary [i.e. orderly] personal uninterrupted succession of pastors to be of the integrity of a true church (which is the ground of his exception), have therefore an intention, or can be justly suspected thereupon to have any intention, to introduce the pope. The eastern, southern, and northern churches are all of them

1 Works, vol. III. p. 523. 


\section{The Restoration Period}

for such a personal succession, and yet all of them utter enemies to the pope. Secondly, I cannot assent to his minor proposition, that either all or any considerable part of the episcopal divines in England do unchurch either all or the most part of the protestant churches. No man is hurt but by himself. They unchurch none at all, but leave them to stand or fall to their own Master. They do not unchurch the Swedish, Danish, Bohemian churches, and many other churches in Polonia, Hungaria, and those parts of the world, which have an ordinary uninterrupted succession of pastors, some by the names of bishops, others under the name of seniors unto this day (I meddle not with the Socinians). They unchurch not the Lutheran churches in Germany, who both assert episcopacy in their confessions, and have actual superintendents in their practice, and would have bishops, name and thing, if it were in their power. Let him not mistake himself; those churches which he is so tender of, though they be better known to us by reason of their vicinity, are so far from being " all or the most part of the protestant churches," that being all put together they amount not to so great a proportion as the Britannic churches alone. And if one secluded out of them all those who want [i.e. lack] an ordinary succession without their own faults, out of invincible ignorance, or necessity, and all those who desire to have an ordinary succession either explicitly or implicitly, they will be reduced to a little flock indeed ${ }^{1}$.

Bramhall advises Baxter and his friends not to make it harder to give an affirmative answer to the question whether the orders of this latter class of churches are valid:

But let him set his heart at rest; I will remove this scruple out of his mind, that he may sleep securely upon both ears. Episcopal divines do not deny those churches to be true churches wherein salvation may be had. We

${ }^{1}$ Works, vol. III. pp. 516 foll. 
advise them, as it is our duty, to be more circumspect for themselves, and not to put it to more question whether they have ordination or not; or desert the general practice of the universal church for nothing, when they may clear it if they please. Their case is not the same with those who labour under invincible necessity. What mine own sense is of it, I have declared many years since to the world in print.... Episcopal divines will readily subscribe to the determination of the learned Bishop [Andrewes] of Winchester [to Du Moulin $]^{1}$.... This mistake proceedeth from not distinguishing between the true nature and essence of a church, which we do readily grant them, and the integrity or perfection of a church, which we cannot grant them without swerving from the judgment of the catholic church ${ }^{2}$.

All along, Bramhall has been using the phrase " episcopal divines" with evident dislike. After a while, he says why:

In styling them "episcopal divines" he doth tacitly accuse himself to be an anti-episcopal or at least no episcopal divine. What odious consequences flow from thence, and how contrary it is to the title of " catholic," which he gives himself in the frontispiece of this treatise, I had much rather he should observe for himself, than I collect. Catholic and anti-episcopal are contradictory terms. From Christ's time till this day there was never any one "catholic" in the eastern, southern, or northern churches who professed himself to be anti-episcopal, but only such as were cast out for heretics or schismatics. The same I say of the western church for the first fifteen hundred years. Let him show me but one formed church without a bishop, or the name of one lay-presbyter in all that time... before Calvin's return to Geneva in the year 1538 , after he had subscribed the Augustan confession and apology for bishops, and I will give him leave to be as anti-episcopal as he will ${ }^{3}$.

1 See above, p. 70.

${ }^{2}$ Works, vol. III. p. 5 I 8.

3 Ibid. p. 53x. 
He recounts the early reformers who approved of bishops, heading the list with the Bohemian Brethren, and then says :

I conclude that all divines throughout the Christian world, who maintain a necessity of orders, ever were and still are episcopal divines, except some weaker and wilful brethren, who for their antiquity are but of yesterday, and for their universality come much short of the very Donatists in Africa, condemned by all moderate and rational persons of their own communion. And therefore $\mathrm{Mr}$ Baxter might have done better to have given his pretended designers a lower and more distinctive name than that of "episcopal divines.".

Yet, with all his anti-presbyterian conviction, Archbishop Bramhall was willing to go as far as he could to conciliate the feelings of men who had been employed under the presbyterian régime. At (presumably) his first visitation after the Restoration, he called for the letters of orders of his clergy.

Some, we are told, had no other but their certificates of ordination by some presbyterian classes, which, he told them, did not qualify them for any preferment in the church. Upon this the question arose, "Are we not ministers of the gospel ?" To which his Grace answered, "That was not the question"; at least he desired for peace sake, that might not be the question for this time. " I dispute not," said he, "the value of your ordination, nor those acts you have exercised by virtue of it; what you are, or might be, here when there was no law, or in other churches abroad. But we are now to consider ourselves as a national church limited by law, which among other things takes chief care to prescribe about ordination; and I do not know how you could recover the means of the church, if any should refuse

1 Works, vol. III. p. 536. 
to pay you your tithes, if you are not ordained as the law of this church requireth; and I am desirous that she may have your labours, and you such portions of your revenue as shall be allotted you, in a legal and assured way." By this means he gained such as were learned and sober ${ }^{1}$.

The men were, of course, reordained, if that is the right word ; but in the letters of orders, at any rate in one case, Bramhall inserted the clause :

Non annihilantes priores ordines (si quos habuit) nec invaliditatem eorum determinantes, multo minus omnes ordines sacros ecclesiarum forinsecarum condemnantes, quos proprio Judici relinquimus, sèd solummodo supplentes quicquid prius defuit per canones ecclesiae Anglicanae requisitum, et providentes paci ecclesiae, ut schismatis tollatur occasio, et conscientiis fidelium satisfiat, nec ulli dubitent de ejus ordinatione, aut actus suos presbyteriales tanquam invalidos aversentur ${ }^{2}$.

Beside the great name of Bramhall must be set that of Cosin. Taught in the service of Overall, Cosin knew both the ancient glory of the episcopate and the limits within which the episcopate could be said to be necessary. At the age of 32 , he preached at an episcopal consecration; the sermon followed closely the lines familiar to Anglican divinity. The work in hand was a continuation of that breathing of Christ upon the disciples which

is the solemn deriving of a sacred and ghostly power upon the persons of the holy apostles for the use and benefit of Christ's church ever after. We call it the power of the keys, and those keys which, over and besides them that are committed to the custody of a priest in his ordination to bind

1 Works, vol. I. p. xxiv.

2 Ibid. p. xxxvii. 
a sinful and to loose a penitent soul, are here given, once for all, into the hands of bishops; the key of order to send as Christ sent, and the key of jurisdiction to govern as he governed ${ }^{1}$.

Whatever fables " the too-credulous papists" might believe about the consecrations at the beginning of the late queen's reign, the church of England

ever held firm (and we are able to make it good) in a continued line of succession from former known bishops, and so from this very mission of the apostles ${ }^{2}$.

Cosin had no doubt of the grace conveyed, or of its source :

The bishop imposes hands, but God gives the grace, saith St Ambrose, - of whom we depend immediately for the power of our orders, and are subordinate to no power besides. I speak not of the execution, which I know bishops can suspend, but of the power of order itself, which none can take away when it is once given ${ }^{3}$.

He draws out the dignities of the various orders :

In priests this, to consecrate the sacrament and to meddle with the keys; but I meddle not with them, as being not proper for the day. In bishops (opus diei), to send, ordain, and govern others, as [Christ] sent and governed them. For it was the high priest of old, and not the presbyter, it is the bishop now, and not the vestry-man, nor the priest neither,- that hath authority to put into the priesthood, or to give any orders at all. It is the full consent of reverend antiquity to distinguish the ministers of the gospel into three degrees, answerable to the triple order under the law, as servants to the same Trinity, the God both of law and

${ }^{1}$ Cosin's Works (ed. 1843), vol. I. p. 87.

${ }^{2}$ Ibid. p. 93. Ibid. 
gospel. There are bishops, successors to the apostles, answerable to the high priest; presbyters, succeeding the seventy disciples, answerable to the priests; and deacons, instituted by the apostles, answerable to the levites. I gather, then, that as the putting into the priest's office was penes pontificem, in the high priest's power alone ${ }^{\mathbf{1}}$, so the consecration of bishops, the ordination of priests and deacons, and the putting of them into office or place within the church, was, and is, in the authority and jurisdiction of bishops only, who are the height and the princes of the clergy, as Optatus said, and said it from Ignatius, the oldest father that is ${ }^{2}$.

The preacher went on to speak rather haughtily of the instances to the contrary :

Neither is there any one example to be found in all the stories of the church of any holy orders that were ever given but by a bishop. I will show you all that may be found. There was an old Arian heretic-they called him Ischyras-a fellow suborned by a faction to accuse Athanasius in the great council of Nice, and he was ordained a priest indeed by Coluthus an imaginary bishop; but because it was afterwards proved that the one was no bishop, the council concluded that the other was no priest, and so put them both off with contempt and scorn ${ }^{3}$.

Aerius and the rest are dismissed in like fashion; but Cosin's sermon ends on a solemn and religious note, which must have been deeply affecting to the hearers.

From the general theory set forth in this sermon Cosin never varied. When, about the year 1652 , he wrote at the request of Clarendon (then Sir Edward Hyde) his Regni Angliae Religio Catholica, he said:

1 I Samuel ii. 36.

2 Works, vol. I. p. 99.

3 Ibid. p. 100. 
Quos omnis agnovit et venerata est antiquitas, rite ordinatos de clero habemus diaconos, presbyteros, et supra utrumque ordinem episcopos....Non novimus...mutilum episcopis clerum; quorum series nullo unquam tempore apud nos interrupta est, nec in eis consecrandis canon antiquus apostolicus aut Nicaenus violatus. Ordinem enim amplectimur tuemurque vere ecclesiasticum et ab apostolorum temporibus per totum Christianum orbem receptum, quo nihil equidem, cum s. scripturae regulis et exemplis, tum ecclesiae et reipublicae statui magis consentaneum. Consecratio episcoporum... a tribus ad minimum episcopis ordine prius episcopali constitutis per invocationem Spiritus Sancti et impositionem manuum...peragitur....Porro episcoporum sive pastorum munus apud nos non nudum tantum nomen, sed res est; presbyteros et diaconos ordinare, curatos ecclesiarum instituere [etc.]....Presbyterialis potestatis in ecclesia propagandae minister inde ab apostolorum temporibus semper fuit episcopus. Apud nos igitur, sacram antiquitatem quantum possumus per omnia sequentes, presbyteri...ab uno episcopo per invocationem Spiritus Sancti, impositionem manuum, sacri codicis traditionem... solenni more ordinantur, assistentibus eidem episcopo in impositione manuum presbyteris tum praesentibus ${ }^{1}$.

But Cosin afterwards came to state the theory with a very large reserve. His experience as an exile on the continent had the effect of diminishing such sympathy for the Roman church as he may ever have had, and of giving him a new feeling for the French Huguenots, though he never ceased to be conscious of their shortcomings. A little paper of his was preserved in which he tabulated the treatment which the Anglican refugees received at the hands of the Roman Catholics and of the reformed churches

1 Works, vol. IV. pp. 35 I foll. 


\section{The Restoration Period}

respectively. Among other points, while the Roman Catholics " excommunicate us, and abhor to join with us in any sacred action either of prayer or sacraments," the reformed

do most willingly receive us into their churches, and frequently repair to ours, joining with us both in prayers and sacraments.

Accordingly Cosin concludes that

we ought no less to acknowledge them, and to make no schism between our churches and theirs, however we approve not some defects that may be seen among them ${ }^{1}$.

Fuller, the historian, while censuring Cosin for alleged innovations at Durham, when he was a canon there, praised him for his loyalty to the English church during his exile, saying that " he neither joined the church of French protestants at Charentown nigh Paris, nor kept any communion with the papists therein." This drew forth the wrath of Cosin. He wrote to Heylin in 1658 :

But-I would that he and all the world should know it-I never refused to join with the protestants, either here or anywhere else, in all things wherein they join with the church of England. Many of them have been here at our church, and we have been at theirs... I have baptized many of their children at the request of their own ministers.... Many of their people (and of the best sort and quality among them) have frequented our public prayers with great reverence, and I have delivered the holy communion to them according to our own order, which they observed religiously...I have presented some of their scholars to be ordained deacons and priests here by our own bishops...

1 Works, vol. Iv. pp. 337 foll. 
and the church at Charenton approved of it, and I preached here publicly at their ordination ${ }^{\mathbf{1}}$.

Cosin's letter (Feb. 7, I650) to "Mr Cordel at Blois" has often been quoted:

I like your moderation well, in giving so fair and calm an answer to Monsieur Testard's motion for communicating in their church: which truly (to speak my mind freely to you) I would not wish any of ours absolutely to refuse or determine to be unlawful, for fear of a greater scandal that may thereupon arise than we can tell how to answer or excuse : especially if any of us should renounce it upon these two grounds which you allege for them, (I) that they have no priests, (2) that they have no consecration of the elements.

For, as to the first, though we may safely say, and maintain it, that their ministers are not so duly and rightly ordained as they should be, by those prelates and bishops of the church, who since the apostles' time, have only [i.e. alone] had the ordinary power and authority to make and constitute a priest, yet that by reason of this defect there is a total nullity in their ordination, or that they be therefore no priests or ministers of the church at all, because they are ordained by those only who are no more but priests or ministers among them, for my part I would be loath to affirm and determine against them. And these are my reasons :

First, I conceive that the power of ordination was restrained to bishops rather by apostolical practice and the perpetual custom and canons of the church than by any absolute precept that either Christ or his apostles gave about it. Nor can I yet meet with any convincing argument to set it upon a more high and divine institution. From

1 Works, vol. Iv. pp. 397 foll. The two "scholars" were Brevint and Durel, both Channel Islanders, and Anglicans, though at the moment attached to the Huguenots. 
which customs and laws of the universal church, therein following the example of the apostles, though I reckon it to be a great presumption and fault for any particular church to recede, and may truly say that fieri non oportuit, when the college of mere presbyters shall ordain and make a priest, yet I cannot so peremptorily say that factum non valet and pronounce the ordination to be utterly void.

Cosin compares baptism by a layman, which is not iterated :

So may it well be in the case of ordination and the ministers of the reformed congregations in France, who are liable to give an account both to God and his church in general for taking upon them to exercise that power, which by the perpetual practice and laws of his church they were never permitted to exercise.... And yet, all this while, the act which they do, though it be disorderly done, and the ordinations which they make, though they make them unlawfully, shall not be altogether null and invalid.

He then makes an important historical statement which has been much disputed:

Therefore if at any time a minister so ordained in these French churches came to incorporate himself in ours, and to receive a public charge or cure of souls among us in the church of England (as I have known some of them to have so done of late, and can instance in many other before my time), our bishops did not reordain him before they admitted him to his charge, as they would have done if his former ordination here in France had been void. Nor did our laws require more of him than to declare his public consent to the religion received amongst us and to subscribe the articles established. And I love not to be herein more wise, or harder, than our own church is ; which because it hath never publicly condemned and pronounced the ordinations of the other reformed churches to be void, as it doth not those of the unreformed churches neither... (though I hear 
that the ministers here in France and Geneva... will not admit a papist priest himself to exercise the office of a minister among them till they have reordained him), for my part, as to that particular, I dare not take upon me to condemn or determine a nullity of their own ordinations against them: though in the interim I take it to be utterly a fault among them, and a great presumption, deserving a great censure to be inflicted on them by such a power of the church as may by the grace of God be at any time duly gathered together hereafter against them, as well for the amendment of many other disorders and defects in their church, as for this particular inorderly ordination and defect of episcopacy amongst them.

Cosin next brings up the Hieronymian theory of the episcopate, though he will not commit himself to it :

Secondly, besides that [i.e. if we set aside the fact that] this their boldness, presumption, and novelty in setting up themselves, without any invincible necessity that they had so to do, against the apostolical practice and perpetual order of God's church till their days, was always faulted... there have béen both learned and eminent men, as well in former ages as in this, and even among the Roman Catholics as well as protestants, who have held and maintained it for good and passable divinity that presbyters have the intrinsical power of ordination in actu primo, though for the avoiding of schism (as St Jerome speaks) and preserving order and discipline in the church, they have been restrained ever since the first times, and still are,... from exercising their power in actu secundo; ' and therefore that, however their act of ordaining other presbyters shall be void according to the strictness of the canon,... yet that the same act shall not be simply void in the nature of the thing, in regard that the intrinsical power remained, when the exercise of it was suspended and taken from them.

M. 
He gives a copious list of authorities who have adopted that view, including among them, without sufficient grounds, the name of Hooker; but he adds cautiously :

All which authors are of so great credit with you and me, that though we are not altogether of their mind, yet we would be loath to let the world see that we contradict them all and condemn their judgment openly; as needs we must, if we hold the contrary, and say that the ministers of the reformed French churches, for want of episcopal ordination, have no order at all.

Thirdly, the question is not one which concerns the Calvinist churches alone :

If upon this ground we renounce the French, we must for the very same reason renounce all the ministers of Germany besides; for the superintendents that make and ordain ministers there have no new ordination beyond their own presbytery [i.e. presbytership] at all; and then what will become of the protestant party?

Probably by " the protestant party " Cosin means" strictly the Lutherans ${ }^{1}$; but he goes on:

Fourthly, if the church and kingdom of England have acknowledged them, as they did in admitting of them, when they fled thither for refuge, and placing them by public authority in divers of the most eminent cities among us, without prohibiting to any of our people to go and communicate with them,-why should we that are but private persons utterly disclaim their communion in their own country?

His fifth argument was drawn from the way in which St Cyprian was allowed to remain in

1 Compare the way in which he uses the expression "his own party " later on in the letter, p. 408. 
communion by " other churches abroad," although his " error in rebaptizing heretics was as scandalous" to them "as the French is in their ordaining of ministers." The sixth is this, which appears for the first time :

Somewhat it is, that they do not absolutely disclaim episcopacy, nor ever did, but say and hold that their presbyters are bishops, especially the chief presbyters that preside at their ordinations and their courts of jurisdiction. So that the true question between us and them is, not so much whether there ought to be bishops in the church or no, as whether their presbyters be true bishops: wherein I think they will have more to do to defend themselves for want of subordination than of ordination itself.

On these grounds Cosin encourages his correspondent to receive the communion from the French ministers, after availing himself of their offer to accept his "protestation" beforehand, to this effect:

Not to recede in any wise from the doctrine and discipline of the church of England ; nor thereby to approve this discipline of the French churches for a rule to others; or to join with them that renounce episcopacy and condemn the proceedings of our own church or the laws of our own kingdom.

Cosin, however, begs Mr Cordel to obtain from Monsieur Testard definite and formal answers to these two questions, viz.

I. Whether the French churches here reformed hold and urge such an absolute necessity of presbytery, as that all other churches are bound to receive and establish it among them? 
2. Whether episcopacy, or the government of churches by bishops (especially being assisted by presbyters, as ours are by their deans and chapters), be not a lawful order and government in God's church $\mathbf{1}$ ?

Cosin had not heard the last of this letter when the receipt of it was acknowledged. Writing to Peter Gunning on another subject in I657 (March 2I), he says :

What paper that is, which is read and talked of among you as mine concerning the French ordinations, I know not : but some discourse I made upon that subject, and their church and sacraments here, about seven years since, which then gave abundant satisfaction to somebody, who now seems not altogether so well to like it, I cannot tell upon what score. If a perfect copy of my writing (which is long) be among you, I fear not the censure of any moderate and learned man whatsoever; and if the presbyterians think to get any advantage by it, they will much deceive themselves. It was written against the rash assertion of some forward persons here that said absolutely, there was neither any minister, nor any sacrament, nor any church, in France, amongst the French reformed; of which mind neither myself nor any other honest man must ever be ${ }^{2}$.

Gunning's reply is lost, but he was evidently not quite satisfied. Cosin wrote to him again on May 26:

I am very loath that there should be the least difference of judgment in that matter between us. Nor by the words that you express of it do I perceive that you dissent from me at all. For you shall not find... that I ever said presbyters had any power of rightful ordination in the judgment of

1 The letter is in Cosin's Works, vol. Iv. pp. 4or foll.

2 Ibid. p. 420 . Who the "somebody" was can only be conjectured. It might be Clarendon. 


\section{The Restoration Period}

antiquity. Nay, you shall find the contrary, and that I greatly blame them, saying, they will never be able to answer it for presuming to take a power upon them which was never given or committed to them, and that nothing but a case of necessity (reserving their wonted desire of bishops, where they are by no means to be had or permitted) can excuse them. I know it is the interest of the pope and the Jesuits, with other of the like faction, to cry down the jus divinum of episcopacy ; and, as I never was, so by the grace of God I shall never be, of that faction. But the question only is, whether there be such an absolute necessity and precept in that jus divinum in all places and at all times, as, where it cannot be put in practice, there...the ordination of a presbyter by a college of presbyters... shall be utterly void and invalid to all effects whatsoever;... whether in such a case, if you were a bishop, you would ordain the presbyter again or no; which was never yet done in the church of England but in Mr Dury's case alone, and that upon his own earnest desire and pretence of conscience, though all the world saw he looked another way ${ }^{1}$ :- whether the church of England hath ever determined the French and German ordinations by presbyters or superintendents to be null and vain, and hath not rather admitted them at several times in public administrations of the sacraments and other divine offices among us; yea, whether there was not a law made ( 13 Eliz.) to allow such an ordination, then questioned by some persons, whereof I could tell you a long story out of our records in the church of Durham, which I have heretofore diligently perused ${ }^{2}$.

Cosin's memory played him false. To say the least of it, he had not made the plea of necessity

${ }^{1}$ Cosin's grievance against Dury probably arose from Dury's readiness to join with the established sects in England during the commonwealth times.

2 This doubtless refers to the case of Whittingham; see below, pp. 493 foll. 
prominent in his letter to Cordel, as earlier divines did, but rested his defence of French orders on other grounds. No doubt, however, he had had it in mind as a condition. Devoted as always to the memory of Overall, he refers to his opinion :

I could tell you another [story] of Bishop Overall's judgment herein, who was as great a patron of antiquity and the church of England as any bishop or priest that ever lived in it, and was wont to say, "Though we are not to lessen the jus divinum of episcopacy, where it is established and may be had, yet we must take heed that we do not, for want of episcopacy where it cannot be had, cry down and destroy all the reformed churches abroad... and say they have neither ministers nor sacraments, but all is void and null that they do."

He concludes :

This is all the letter drives at, and at nothing else: which truly I cannot apprehend how it either hurts the jus divinum of episcopacy, or excuseth their voluntary and transcendent impiety that have endeavoured to destroy it in the church of England, contrary to the laws of God and his universal church, the mother of us all ${ }^{1}$.

In this mind Bishop Cosin continued to the end of his life. In the notes of his argument about divorce (I669 or I670), in opposition to the majority of the bishops, who were influenced, as he thought, by the decisions of the church of Rome, he says

I know not why they should be called the church of England that join with the council of Trent, and plead so much to uphold it, rather than others that join with all the reformed churches, and plead against that canon of the church of Rome, which hath laid an anathema upon us if we do not agree with them ${ }^{2}$.

1 Works, vol. Iv. p. 448 .

2 Ibid. p. 501. 


\section{The Restoration Period}

His last will sets forth his faith, his loyalty to the English church, his rejection of all heresies and schisms, among whom he ranks " not only the separatists, the anabaptists and their followers,alas, too too many,-but also the new independents and presbyterians of our country."

Moreover I do profess with holy asseveration and from my very heart that I am now, and have ever been from my youth, altogether free and averse from the corruptions and impertinent new-fangled or papistical (so commonly called) superstitions and doctrines, and new superadditions to the ancient and primitive religion and faith of the...catholic church... contrary to the holy scripture and the rules and customs of the ancient fathers. But in what part of the world soever any churches are extant, bearing the name of Christ, and professing the true catholic faith and religion,... if anywhere I be now hindered actually to be joined with them either by distance of countries or variance amongst men or by any other let whatsoever, yet always in my mind and affection I join and unite with them. Which I desire to be chiefly understood of protestants and the best reformed churches ; for where the foundations are safe, we may allow and... peaceably suffer, in those churches where we have not authority, a diversity, as of opinion so of ceremonies, about things which do but adhere to the foundations and are neither necessary or repugnant to the practice of the universal church ${ }^{\mathbf{1}}$.

Cosin's judgment has not the dispassionate sobriety of Bramhall's. His "very good friend" Clarendon felt that he was needlessly vehement in his repudiation of Fuller's misplaced encomium ${ }^{2}$. His letter to Cordel gives too much the impression of

1 Works, vol. IV. p. 527.

${ }^{2}$ See his letter in Cosin's Works, vol. Iv. p. 398, note $n$. 
the special pleader. Gunning and others might well feel anxious, as they evidently did, at the thought that the presbyterians in England would make capital out of it. Cosin was far from intending to aid their cause, but his factum valet could justly be quoted on their behalf. An ordination by presbyters, on Cosin's principles, is more wrong, a great deal, in a country like England, where there are evangelical bishops, than in a country like France; but if it is valid in the one, it can hardly be declared invalid in the other. There can be little doubt that Cosin allowed himself to become prejudiced by the unfriendliness of the French Roman Catholics, from whom he had somehow expected better things. The perversion of his only son to Romanism was a blow which he never forgave. He became the partisan of "the French reformed ${ }^{1 . "}$

Cosin's own action as a bishop was in conformity with the views which he had imbibed from Overall. $\mathrm{He}$ could not indeed allow the sufficiency of presbyterian orders: the law was against it, even if he had wished otherwise. But he was ready to meet a good presbyterian halfway, as Bramhall did. Calamy relates a conference which Cosin held with a man named Frankland, whom he earnestlý desired to gain for the church :

Bishop Cosin solicited him to conform, promising him not only his living, but greater preferment upon his compliance. Mr Frankland told him that his unwillingness to

1 Besides the letters quoted in the text, see the letter in Works, vol. IV. p. $3^{85}$. 
renounce his ordination by presbyters made him incapable of enjoying the benefit of his favour. This engaged him in a debate with the bishop, that was managed with great calmness, and this was the result of it. His lordship condescended to ask whether he would be content to receive a new ordination so privately that the people might not know of it, and have it conditionally, with such words as these, "If thou hast not been ordained, I ordain thee" etc. $\mathrm{He}$ thanked him, but told him he durst not yield to the proposal, at the same time assuring his lordship, that it was not obstinacy, but conscience, which hindered his compliance ${ }^{1}$.

Gunning, to whom some of the letters of Cosin above quoted are addressed, wrote little ; but he had an extraordinary reputation for learning and for wisdom. He was one of the most powerful forces in the restoration settlement, and for that reason was singled out as a chief object of Baxter's dislike. In I682, his chaplain, Saywell, Master of Jesus College, Cambridge, published in his Evangelical and Catholic Unity a rather curious "Vindication of the Right Reverend Father in God, Peter, Lord Bishop of Ely, extorted by the numberless provocations and reflections of Mr Baxter upon his Lordship." Baxter had offered to Gunning and to the world his True and only way to Concord. Saywell's comment is :

Let us then consider the Bishop of Ely's way of concord, which is, by uniting in that ancient catholic and apostolic faith, doctrine, government, administration of sacraments, and order of worship, which was instituted by Christ and his apostles, confirmed by the general councils, received down by the known custom and practice of the churches

1 Calamy's Abridgement, vol. Ir. p. 286 (quoted in Cosin's Correspondence, Surtees Society, vol. II. p. xliv). 
of God throughout all ages, and approved by the primitive fathers and martyrs, and established in this nation, for substance, ever since Christianity was first planted....

Now there is not one settled church, established by public authority, that he is not at concord withal, and holds Christian communion, and would actually embrace and receive to his prayers and sacraments, and count as members of the same mystical body, whereof Christ is the head, though he does not agree with them in their errors and singularities, and only differs from them where they depart from the scripture and the catholic church ${ }^{1}$.

He proceeds to enumerate those churches " which do approve of our communion, and are upon occasion admitted to it" :

First, does not his Highness the Prince of Orange and his noble and honourable retinue join in communion with us, as often as they have occasion to come over hither; and are not any of the ministers and others of the Dutch churches publicly permitted to come to our communion? And do we not thereby own them for Christians and fellow members of the same catholic church? And do they not thereby own us for the like? If at any time any of the French protestants come over to our country, do we not likewise admit them to our public prayers and sacraments, and so profess our concord with them in the substantial principles of the Christian religion? Come we likewise to consider the remains of the ancient Bohemians, do we not hold all friendly communion with them? Nay, the Bishop of Ely does subscribe yearly to the maintenance of scholars in the universities to be sent over to be ministers amongst them; and when their bishop [Hartmann] was lately here to solicit our church's charity towards their relief, none was more forward than his lordship, as that reverend and learned bishop and his brother did with ample thanks and hearty

1 Saywell's Evangelical and Catholic Unity, pp. 299 foll. 


\section{The Restoration Period}

prayers to God for his lordship acknowledge to me... . The same charity and concord is always shown to the Lutheran churches, some of whom have often communicated with the Lord Bishop of Ely.... The like concord I can show with the Helvetian, Hungarian, and Transilvanian churches, and all that profess the catholic faith ${ }^{1}$.

After speaking of Gunning's relation to the eastern churches and to Rome, his chaplain says who they are that he will not communicate withal:

His love of truth and zeal for catholic unity does teach him not to communicate with them that deny the catholic faith or break catholic unity. Such are infidels, heretics, schismatics, and openly wicked livers.... These the church of England, and the Bishop of Ely taught by her, do manifestly reject from their communion. And whereas this is made a large pretence by many, to reject whom they please from their communion,...the church of England, and the Lord Bishop of Ely, do not hereupon take an occasion to vent their passion against anybody and presently brand them with the name of heretic and schismatic etc., but... embrace all those that profess the common received faith and order of the catholic church.... According to this rule, not only Socinians are to be shut out from all Christian communion by the church of England and the Lord Bishop of Ely, but even obstinate anabaptists and quakers, as holding manifest and gross heresies.... And by the same rule all those that set up altar against altar, and hold separate congregations, contrary to the law of this church, are to be held as schismatics, and were condemned for such by the ancient general and particular councils and all the catholic fathers and martyrs, and thought not fit to be received into Christian communion or accounted lively members of the catholic church. Such therefore the church of England and the Lord Bishop of Ely reject from their communion ${ }^{2}$.

1 Evangelical and Catholic Unity, pp. 302 foll.

${ }^{2}$ Ibid. pp. 3I 7 foll. 
Baxter's party and the bishop's were alike in maintaining that there ought to be but one church, that is, that one side or the other ought to give in; and Saywell states not unfairly how the matter lay :

It will not be amiss to enquire which party ought to yield to the other for order and peace sake.... There is no doubt made by persons that understand what they say, that bishops have fulness of all ecclesiastical power and order, and that their ordinations and sacraments regularly made and administered are lawful and valid; and this none of the furious contenders for presbytery can deny. But then they also maintain that every presbyter is as to order and office equal to a bishop, and has the same fulness of power and authority originally in himself, though as to the exercise of it, for order sake and by consent, he may be bound up and restrained.... On the other side, it has been the tradition and doctrine of the Christian church in all ages...that no ordinations are valid, or ought to be made, but by bishops... where with moral diligence such ordinations may be had....Presbyters, where there are or can be no bishops, may, during that necessity, design persons that are best fitted and qualified to supply the place of ministers; but still they ought to acknowledge they are in an imperfect state, and be ready to receive a regular ordination, and submit to lawful ministers as soon as they can be had. So that they do not hereby unchurch any foreign churches that cannot have bishops, or shut them out from the number of Christ's disciples and a possibility of salvation, but deplore their unhappiness, and counsel them, as soon as they can, to make up this defect and to return to the ancient catholic order of the primitive and most other churches at this day.

- The matter being thus stated on both sides, 'tis easy for any peaceable and rational man to determine which party ought to yield to the other; for there is no reason that the ancient apostolical order should give place to the 
modern; that [that] which people entered upon only in case of necessity should be preferred before that which was chosen freely and when the church was in none of those straits; that [that] which is undoubtedly good and valid in the confession of all parties should be set aside by that which the church of God never yet did nor the greatest part of Christians never will approve of ${ }^{1}$.

Such were the ideas that prevailed in the circle of Bishop Gunning.

Almost a twin name with Gunning's is that of the illustrious Pearson, who succeeded him in $\mathrm{x} 66 \mathrm{I}$ in the Lady Margaret's Professorship at Cambridge. In that capacity Pearson delivered the Determinationes Theologicae, of which the first three bear the following titles: I. Ordo episcopalis est apostolicus. II. Ordinandi potestas solis competit episcopis. III. Ordinatio Anglicana complet totam essentiam externae vocationis ad ministerium.

The method of the Determinationes is, of course, scholastic, and Pearson, in the first of them, goes patiently through his proof that there is such a thing as holy order, and then that there is more than one holy order, before coming to the assertion that the episcopal order is distinct from the others. He does it in this manner :

Certe si ordo sit nihil aliud, uti diximus, quam spiritualis potestas tradita ordinato, tum distincta potestas est diversus ordo: sed spiritualis potestas tradita episcopo distincta est a potestate concessa presbytero. Nulli unquam presbytero, qua presbytero, concessa est potestas ordinandi diaconum aut presbyterum aut episcopum. Nulli unquam presbytero, qua tali, concessa est potestas regendi presbyteros, aut per

1 Evangelical and Catholic Unity, pp. 322 foll. 
se excommunicandi Christianos. Sed episcopis, quatenus episcopi sunt ordinati, haec potestas omnino est concessa.

He then comes, as he says, to the "throat" of the matter. From two quarters, the papal and the presbyterian, the truth is authoritatively denied. The modern papist contention he traces to Soto, well known in connexion with Cranmer's last days. Of the presbyterian contention he writes, taking up a point made by Andrewes :

Illi, qui aut ex necessitate aut ex ambitione auctoritatem episcopalem presbyteratui attribuunt, volunt presbyteros episcopis, hoc est filios patribus, priores esse, nihilque aliud episcopos esse quam presbyteros a presbyteris promotos, atque ideo, cum fiunt episcopi, non ordinatos sed consecratos dici. Habemus quidem in ecclesia nostra formulam consecrationis episcoporum, habemus et aliam ordinationis presbyterorum; non tamen inde concludi potest episcopatum non esse ordinem, magis quam ex eodem concludatur presbyteratum non esse ordinem sacrum. Ordinatio episcoporum dicitur consecratio, non ad negationem, sed ad distinctionem et praelationem ordinis.

He concludes accordingly :

Est itaque episcopatus a presbyteratu distinctus; et distinctio nunquam non observanda, quam tradidit Optatus, "Certa membra thabet ecclesia, episcopos, presbyteros, diaconos, et turbam fidelium ${ }^{1}$."

He proceeds to prove, as against Saumaise and Blondel, that this order is apostolic, and apostolic in all the three ways in which a thing can be said still to be apostolic, viz. " quod fuit sub apostolis, ab apostolis, in apostolis." Under the second of these heads he affirms :

1 Minor Works (ed. Churton), vol. I. pp. 274-278. 


\section{The Restoration Period}

Non tantum viventibus videntibusque apostolis facti sunt episcopi, sed ipsis etiam nominantibus, ordinantibus, manuumque impositione consecrantibus, adeoque episcopalem ordinem conferentibus: hoc est, apostoli solenniter dederunt quibusdam hominibus [Timotheo, Tito], separatim et singulariter sumptis, potestatem ad conferendos ordines, ad regendos presbyteros, ad excommunicandos impios, ad confirmandos neophytos, ad faciendum quicquid presbyter, qua talis, facere legitime non potest ${ }^{1}$.

Under the third head he draws the usual distinction between what was unique and temporary in the endowment of the apostles, and what was for all time, to be transmitted to the bishops.

Est itaque apostolus episcopus extraordinarius; est episcopus apostolus ordinarius; atque ita episcopatus fuit in apostolis a Christo institutus, in successoribus apostolorum ab apostolis derivatus ${ }^{2}$.

The second Determinatio discusses the three propositions of the opponents, that the power of ordaining is innate in presbyters, that after the apostles' time the church restricted it to bishops, and that bishops and presbyters still confer orders together by equality of right. The first proposition has no scriptural warrant, but depends for its force upon the second; the second has no historical evidence to show, but depends upon the third. So Pearson demonstrates that the imposition of the hands of the presbyters along with those of the bishop was unknown in the west till the Carthaginian council at the end of the fourth century, and has never been known in the east, and that the interpretation put upon it by the western councils which prescribed

1 Minor Works, vol. I. p. 282.

2 Ibid. p. 284. 
it was quite contrary to that put upon it by the presbyterians ${ }^{\mathbf{1}}$.

In a Latin sermon to the clergy, on Aaron's rod, preached while he was Master of Trinity, Pearson puts forward the doctrine of the apostolical succession clearly and briefly :

Sicut misit Pater Christum, ita Christus apostolos, apostoli successores. Imposuit manus Timotheo Paulus, atque sic factus est $a b$ apostolo episcopus. Imposuit manus iterum Timotheus, et factus est ab episcopo aut presbyter aut episcopus. Quodcunque factum, nunquam misit nisi qui missus est, nunquam ordinavit nisi qui ordinatus est, nunquam dedit nisi qui acceperat.... Non a populo neque per populum, sed a Deo per S. Paulum Titus episcopus....Per hanc traditionem apostolicam tota ordinandi potestas in episcopis resedit; nulla alii cuiquam in Novo Testamento indulta est, nulli in veteri ecclesia permissa. Quicquid unquam ad honorem presbyteratus dictum, semper ei ordinatio negata est; ut filios crearet, permissum, non ut patres... Sane qui ordinandi potestatem presbyteratui originaliter tribuunt, non possunt non in Aerii haeresin delabi ${ }^{2}$.

These, however, are somewhat arid orthodoxies, and scarcely seem to touch life. But a letter of Pearson's, written in I668, brings out the religious value which Pearson felt to inhere in the practice of ordination in the church. "A person of quality" wrote to ask him, as one who had the reputation of being " a moderate divine," whether he could approve of the appointment of a pastor in the parish where his correspondent lived, "who is not a pastor canonically ordained, but hath received something

1 Minor Works, vol. I. pp. 287 foll.

2 Ibid. vol. Il. pp. 73 foll. 
which he calls ordination, either after a classical or congregational way," that is either a presbyterian or an independent ordination. Pearson replied in his letter on "Promiscuous Ordinations," which ought to be widely known.

"Sir," he wrote:

I cannot take any delight as to the differences in matters of religion, but in the composure of them only: and if I understand myself, nothing can ever alter that temper by which I have been so long inclined to a due enlargement and indulgence for such as are ready to afford a rational compliance. But I hope that no such facility of nature or opinion shall ever reduce me to that weakness, as to betray the great and everlasting concerns of the church, or to give over the indispensable duty of endeavouring that unity which is necessary to its conservation.

That the order of the ministry is necessary to the continuation of the gospel according to the promises of Christ, as it was to the first plantation of it according to his institution, is a doctrine indubitable. That this ministry is derived by a succession and constant propagation, and that the unity and peace of the church of Christ are to be conserved by a due and legitimate ordination, no man who considereth the practice of the apostles and ecclesiastical history can ever doubt. This way of ordination, having continued so many ages one and the same, could never be considerably altered without some great commotions and dissensions in the church, and the manifest breach of union and communion in that body: whomsoever we judge guilty of the breach of that union, which is not necessary now to dispute. And as the first introduction of different ordinations caused a standing and settled opposition, precluding all ways of reconciliation ${ }^{\mathbf{1}}$, so they cannot be brought into any

1 Pearson here refers to the action of the continental reformers and its effect upon the church at large.

M. 
one church, but they must make such a division and disparity in the administrations, as will amount to no less than a schism.

However [i.e. at any rate], in the peculiar and happy condition of our church, these promiscuous ordinations, if at all allowed by it, are most destructive to that which is the safety and honour of it. We have the greatest felicity which could happen to a reformation, as being regular and authoritative, that we have so taken away the many mistakes and errors which had been introduced by a long ignorance and usurpation, as to retain a perfect compliance with the ancient church: and therefore we can boldly and truly affirm, we are the same with the primitive Christians, even those of Rome: and while we hold and maintain our ordinations legitimate, we speak the same language with the most glorious fathers, martyrs, and saints of those happy and pious times. But if we once admit a diversity in our ordinations, we have lost the honour of succession, we have cast away our weapons of defence; we have betrayed our own cause, and laid ourselves open to the common enemy of all protestants, and we shall at last inevitably fall into the Socinian doctrine, to deny all necessity or use of any mission or ordination.

Pearson then shows how impossible it would be to maintain the discipline of the church, if invalid ordinations were condoned:

If all sorts of ordination be any way established by sufficient authority, if what is so earnestly desired be indulged, " that a man once ordained any way be still held and retained for a labourer in the harvest," the most legitimate process in ecclesiastical affairs will become ineffectual and irrational.... What an uncomfortable and discouraging confusion is this, whereby presentments shall be made of those persons who are conscientiously conformable to the doctrine and orders of the church, for actions or omissions proceeding solely out of that conscience and conformity; and they who factiously 


\section{The Restoration Period}

or erroneously dissent from that doctrine and order shall avoid their own [presentment] and promote the presentment of others, and in this error or faction shall be protected and encouraged by a superinduced authority! Thus by promiscuous ordinations the doctrine of the church will be rendered indefensible and the discipline unpracticable.

Then Pearson brings it home to the enquirer what perplexity would be in store for himself, his family, and his neighbours, if his parish minister was without due orders :

If a person only qualified by a congregational mission should be set over you authoritatively as your lawful pastor, to whose ministerial acts it is expected you should apply yourself in all public matters of religion; you being of a constant persuasion that the validity of such acts hath a necessary relation to the legitimacy of ministry, and of as certain an opinion that such a mission cannot amount to a legitimate ordination; I cannot see what comfort you can take in any compliance with such administrations. Nay, further, if a person be said to have obtained orders after the presbyterian way in the late times, when he might have received them from a bishop, and, since the happy restitution of public order in the church, when many of his brethren have submitted, still obstinately refuses to receive ordination after the established way of the church of England; in this case, if you doubt whether his ordination be valid or conclude it null, I confess I know no argument to convince you or to incline you to another persuasion.

He describes the uncomfortable feeling with which his correspondent would attend the church prayers, with such a person taking the priest's part; the irregularity of his baptisms, though they would not be invalid. 
As to the other sacrament, the supper of the Lord, your case is far worse.... If you be resolved that your pastor established is not a priest or presbyter, and consequently hath no power to consecrate the elements, or render them sacramental, I cannot see how you can follow him to the holy table, or with what comfort or conscience you can bring your family, or concur with your neighbours, to receive the elements from his hands.

When death approaches, and confession and absolution may be desirable,

you will never acquiesce in the absolution, where you acknowledge no commission, nor can you expect any efficacy, which dependeth upon the authority.

The impressive letter ends as follows :

These and the like I look upon not as formal objections or cavils, but as real and severe complaints, raised upon sober and religious grounds,-matter for Christian zeal rather than moderation. And therefore I cannot persuade myself that any person endued with any kindness or care of the religion settled in this nation can ever contrive or assent unto so great a discouragement to the conscientious professors of it, and confusion in the management and administration ${ }^{1}$.

Pearson's successor in the Mastership of Trinity, Isaac Barrow, composed a short Discourse concerning the Unity of the Church. In the course of it he says:

All Christian churches are one by a specifical unity of discipline, resembling one another in ecclesiastical administrations, which are regulated by the indispensible sanctions and institutions of their Sovereign. They are all bound to use the same sacraments, according to the forms appointed by our Lord, not admitting any substantial alteration. They 


\section{The Restoration Period}

must uphold that sort of order, government, and ministry in all its substantial parts, which God did appoint in the church, or give thereto, as St Paul expresseth it ; it being a temerarious and dangerous thing to innovate in those matters which our Lord had a special care to order and settle.... In lesser matters of ceremony or discipline, instituted by human prudence, churches may differ, and it is expedient they should do so,... but no power ought to abrogate, destroy, or infringe or violate the main form of discipline, constituted by divine appointment.... Hence was Aerius accounted a heretic, for meaning to innovate in so grand a point of discipline as the subordination of bishops and priests ${ }^{1}$.

In the latter part of the Discourse, where Barrow is combating some of Thorndike's positions, he meets the objection that what he has said may seem to "favour the conceits of the independents."

I answer, No; for... we do assert that every church is bound to observe the institutions of Christ and that sort of government which the apostles did ordain, consisting of bishops, priests, and people.

The other reasons need not delay us here.

In the first of four sermons on Obedience to our Spiritual Guides and Governors, Barrow sets forth the doctrine of the church, as he understood it, without the constraint which is apparent in the more scholastic treatise.

The church is acies ordinata, a well marshalled army, wherein under the Captain General of our faith and salvation...there are divers captains serving in fit degrees of subordination; bishops commanding larger regiments, presbyters ordering less numerous companies ;... all bishops and priests being guided by synods established, or congregated

${ }^{1}$ Section vir. 
upon emergent occasion; many of them ordinarily by those principal bishops who are regularly settled in a presidency over them; according to the distinctions constituted by God and his apostles, or introduced by human prudence...

Of this distinction there was never in ancient times made any question, nor did it seem disputable in the church, except to one malcontent, Aerius; who did indeed get a name in story, but never made much noise or obtained any vogue in the world. Very few followers he found in his heterodoxy. No great body even of heretics could find cause to dissent from the church in this point;... and no wonder, seeing it standeth upon so very firm and clear grounds; upon the reason of the case, upon the testimony of holy scripture, upon general tradition and unquestionable monuments of antiquity, upon the common judgment and practice of the greatest saints, persons most renowned for wisdom and piety in the church.

Barrow developes these various grounds. His statement of the consent of antiquity is well put by the great mathematician :

The primitive general use of Christians most effectually doth back the scripture, and interpret it in favour of this distinction, scarce less than demonstrating it constituted by the apostles;... for how could it without apparent [i.e. evident] confederacy be formed, how could it creep in without notable clatter, how could it be admitted without considerable opposition, if it were not in the foundation of those churches laid by the apostles? How is it likely that, in those times of grievous persecution falling chiefly upon the bishops,... an ambition of irregularly advancing themselves above their brethren should so generally prevail among the ablest and best Christians?... In fine, how can we conceive that all the best monuments of antiquity down from the beginning (the Acts, the Epistles, the histories, the commentaries, the writings of all sorts coming from the blessed martyrs and 
most holy confessors of our faith) should conspire to abuse us ; the which do speak nothing but bishops ; long catalogues and rows of bishops succeeding in this and that city; bishops contesting for the faith against pagan idolaters and heretical corrupters of Christian doctrine; bishops, here teaching and planting our religion by their labours, there suffering and watering it with their blood?

\section{The preacher cannot enlarge on this point:}

I shall only further add that if any man be so dully or so affectedly ignorant as not to see the reason of the case, and the dangerous consequences of rejecting this ancient form of discipline ; if any be so overweeningly presumptuous as to question the faith of all history, or to disavow those monuments and that tradition upon the testimony whereof even the truth and certainty of our religion and all its sacred oracles do rely ; if any be so perversely contentious as to oppose the custom and current practice of the churches through all ages down to the last age; so self-conceitedly arrogant as to condemn or slight the judgment and practice of all the fathers (together also with the opinion of the later most grave divines, who have judged episcopal presidency needful, or expedient where practicable); so peevishly refractory as to thwart the settled order of that church in which he was baptized, together with the law of the country in which he was born; upon such a person we may look as one utterly invincible and intractable: so weak a judgment and so strong a will who can hope by reason to convert? I shall say no more to that point.

\section{He concludes this part of the sermon thus :}

The irovi $\mu \in v o$ then (the guides and governours) in our text are primarily the bishops...then secondarily the presbyters in their station...together with the deacons as their assistants. Such the church always hath had, and such by God's blessing our church now hath, toward whom the duty of obedience is to be performed. 
Barrow then shows how the true guides may be known from " bold pretenders, who are not indeed guides but seducers, not governours but usurpers and sacrilegious invaders of this holy office." The true guides are

Those... who constantly do profess and teach that sound and wholesome doctrine which was delivered by our Lord and his apostles...those who celebrate the true worship of God, and administer the holy mysteries of our religion in a serious, grave, decent manner...those who derive their authority by a continued succession from the apostles; who are called unto and constituted in their office in a regular and peaceable way, agreeable to the institution of God and the constant practice of his church, according to rules approved in the best and purest ages... who also in a pious, grave, solemn manner, with invocation of God's blessing, by laying on the hands of the presbytery are admitted thereunto.

The false guides, of course, are the opposite. These

without any apparent commission from God, or allowable call from men, or extraordinary necessity of the case, in no legal or regular way, according to no custom received in God's church, do intrude themselves into the office, or are only assured thereto by ignorant, unstable, giddy, factious people...for no just cause, and upon any slender pretence, withdraw themselves and seduce others from the church... deserting its communion, impugning its laws, defaming its governours, endeavouring to subvert its establishment... in their doctrine or practice deflect from the great beaten roads of holy scripture, primitive tradition, and catholic practice $^{\mathbf{1}}$.

1 Barrow's Works, vol. III. p. 278 (edited by Tillotson, r686). 
Simon Patrick was not a man of commanding genius, but he may be taken as a good sample of the well-read, well-meaning bishop of the latter half of the seventeenth century. His Friendly Debate between a conformist and a nonconformist was not concerned with ordination questions; but one of the replies which it drew forth plunged into those questions, and averred that the church of England itself permitted presbyterian ordination. It alleged the well known puritan Gataker as an example. He had been ordained by a suffragan bishop, which the author of this reply, with ignorant erudition, took to be the same thing as a chorepiscopus and much the same thing as a rural dean. In an appendix to the Friendly Debate Patrick demolished the mistake:

Nor did our church, he says, ever acknowledge such power residing in... any mere presbyters...to ordain priests ${ }^{\mathbf{1}}$.

He discussed one or two supposed exceptions. Saravia, in his letter to the ministers in Guernsey, spoke of men there being ordained " by their bishop or his demissories" ; Patrick thinks that the curious word means the suffragans of Winchester. He denies that the Scottish consecration of I6Io was a case in point: and Scotland was not England ${ }^{2}$. The reply had spoken of " hectors for conformity, who judge Aerius a greater heretic than Arius, who have more charity for those that deny the deity of our Saviour than for those that scruple the strict jus divinum of episcopacy." Patrick's rejoinder is not uninstructive :

1 Works (ed. I 858 ), vol. vi. p. 287 .

${ }^{2}$ Ibid. p. 288. 
Let me tell you in the first place that it is no hectorism to assert the divine right of episcopacy in the strictest sense. This is no upstart opinion, broached by some swaggering hotbrained men, who love to rant and vapour beyond other folk, .. . but hath been anciently believed in this church from the very beginning of the reformation, and maintained by the soberest men in it. I know they would have you to think otherwise, and have endeavoured to persuade the world that it is a novel doctrine advanced of later times by some proud and haughty divines. Mr Robert Baily made bold to say that before Bishop Bancroft's time the bishops did unanimously deny episcopacy to be of divine right ${ }^{\mathbf{1}}$. And the letter to Dr Samuel Turner, printed 1647, will not allow it to be so ancient, but affirms that " it is an opinion but lately countenanced in England, and that by some of the more lordly clergy." He means, I think, Archbishop Laud, as some since have explained it. But both the one and the other of these talked at random out of their own imaginations, not from historical observation ${ }^{2}$.

Patrick's own historical observation leads him to cite Archbishop Whitgift and Bishop Bilson as earlier examples, and "old Bernard Gilpin" before either.

But there is an authority ancienter than all these, viz. " the form and order of making and consecrating bishops," etc., confirmed by act of parliament. In which three things are considerable. The very first words of the preface are that "it is evident to all men reading the holy scriptures and ancient authors that from the apostles' time there have been these orders in Christ's church, bishops, priests, and deacons." Then, secondly, the prayer after the litany at the consecration of a bishop begins in this manner, "Almighty God, giver of all good things, which by thy Holy Spirit hast

1 In a reply to Bramhall's Fair Warning against the Scots Discipline.

2 Works, vol. vi. p. 306. 
appointed divers orders of ministers in thy church," etc. ; which must needs be understood of those before named. And lastly, the first question to the person to be consecrated is, "Are you persuaded that you be called to this ministration according to the will of our Lord Jesus Christ?" to which the answer is, "I am so persuaded." Put now all these together, and you will not be able to conceive.... how these words should fall from any men not possessed with this tenet, that episcopacy is of divine right.... And all this hath not been said only of late, nor countenanced only by some few, and those of the more lordly clergy ${ }^{\mathbf{1}}$.

One of the less pleasing characters in English church history during the same half of the seventeenth century was Samuel Parker, who rose to be Bishop of Oxford under James II. Perhaps one of the best things that can be said about him is that he was a friend of Patrick's. But he was a man of a very different temper. His chief work, published in I670, ventured to assume the already illustrious title of Ecclesiastical Polity. But its aim and method was not that of Hooker. It was a frank assertion of Erastianism in excelsis. Its full title is $A$ discourse of Ecclesiastical Polity; wherein the Authority of the Civil Magistrate over the Consciences of Subjects in matters of External Religion is asserted; the Mischiefs and Inconveniences of Toleration are represented, and all Pretences pleaded in behalf of Liberty of Conscience are fully answered. This clever book does not so much as touch upon the subject which its short title seems to offer. But eleven years later Parker published a book of a more positive nature. It was called The

${ }^{1}$ Works, vol. vi. p. 307. Cf. Discourse about Tradition, ibid. p. 488. 
Case of the Church of England briefly and truly stated, in the three first and fundamental Principles of a Christian Church. These are (I) the obligation of Christianity by divine right, (2) the jurisdiction of the church by divine right, (3) the institution of episcopal superiority by divine right. The first of these principles is asserted as against Hobbes and his followers, the second against Selden, the third against

the opinion of some learned and moderate divines both at home and abroad, that grant indeed the necessity of some kind of government in the church, but deny it to have been settled and fixed by our Saviour in any one form or upon any certain order of men, and leave it wholly at somebody's disposal (though who that somebody is they have not as yet clearly determined) to appoint officers and governors as shall be thought most prudent and suitable to the present circumstances of things 1 .

\section{Of these three opinions}

the first supposes a church without religion; the second a society without government; the third a government without governors. And what can be more absurd and inconsistent?... Though these opinions are not equally wicked in themselves, the first being open and avowed atheism, yet are they equally destructive to the fundamental constitution of the Christian church, as it is a society founded not by any human authority but divine right ${ }^{2}$.

The first two are to be dealt with rather summarily,

but with the third sort I intend to treat more largely, because that is the church at this present in fashion, and is become popular and plausible by the authority of some

1 The Case of the Church, etc., p. 4.

2 Ibid. p. 5 . 


\section{The Restoration Period}

learned men that have owned and asserted it. And therefore I shall carefully demonstrate its vanity and falsehood, from our Saviour's express institution; from the certain practice of the apostles; from all the most undoubted records of the church; and lastly from the great inconveniences that would unavoidably follow upon it. And when we have gained these three fundamental points, we may then and not till then proceed to farther proposals for the true settlement of the church of England; for without them, whatever men may talk of it, all their discourse of a church is no more than a notion and a phantasm, a Platonic commonwealth, and a world in the moon ${ }^{1}$.

When he comes to the third branch of his subject, Parker speaks, like others, of the twelve and the seventy, and adds

I will freely grant that our Saviour's design in lifetime seems to have been not so much to found churches himself, as to have prepared and instructed his disciples how to do it after his departure. So that he rather made a specimen of the constitution of his church than erected any standing fabric of it ${ }^{2}$.

For the apostolic times, Parker " cannot but admire" to see men like Saumaise and Blondel persisting to argue "from the equivalency of the words bishop and presbyter,"

notwithstanding it is so evident and granted by themselves that the apostles enjoyed a superiority of power over the other pastors of the church.... For if it be proved, and themselves cannot deny it, that there was an inequality of offices, from the superiority of the apostles, it is a very childish attempt to go about to prove that there was not, because there were two synonymous terms whereby to express the whole order of the clergy ${ }^{3}$.

1 The Case of the Church, etc., p. 6.

${ }^{2}$ Ibid. p. 133 .

3 Ibid. p. 137. 
To the argument that apostolical practice was not always binding upon after ages, he replies :

It is enough in this case, that what the apostles did was in pursuance of our Saviour's institution, and that in a matter of perpetual concernment to the church ; and they who require to the obligation of such an apostolical practice an express law to declare their intention that it should bind for ever are guilty of the same fantastic niceness as they that require the same for the perpetuity of every divine law.... And for that reason I shall add nothing more to what I have already said as to this particular, than to grant that whatever the apostles either commanded or practised upon some particular temporary and occasional cases was not sufficient to found any universal and unchangeable obligation, because the reason of the precept was apparently transient and the goodness of the action casual. But [it is] otherwise if there were any precept or practice of theirs (though it were not founded upon any divine institution) that did not relate to peculiar occasions and circumstances, but are or may be of equal usefulness to all places, times, and persons ${ }^{1}$.

Parker treats with skill and learning the testimonies of the fathers, reserving to the last the much quoted language of Jerome.

Before I come to answer the whole argument, I cannot but observe what disingenuous advantage these men make of the hasty expressions of that good father. Let him in the heat and eagerness of dispute but drop an inconsiderate word,-it immediately serves to justify all their innovations.... Is it not very strange that two or three hasty passages of this single father, not only against the concurrent testimony of all the ancient church, but against his own express opinion, should be seized upon with so much zeal and greediness to give defiance to all the practice of antiquity ${ }^{2}$ ?

1 The Case of the Church, etc., pp. I4I foll.

${ }^{2}$ Ibid. p. 2 I8. 


\section{The Restoration Period}

He concludes his well-reasoned investigation with the words :

I cannot see how the divine and apostolical right of episcopacy, if the providence of God had designed to make it unquestionable, could have been made more evident, either from common reason or catholic tradition ${ }^{1}$.

In a postscript Parker says that the really important thing is to declare what we contend for :

For as for the general term of protestancy, it is an indefinite thing; so that if all the men in England that are enemies or no friends to the pope of Rome may be listed under that name, we have some protestants that believe there is a God, and some that believe there is none; some that believe they have a Saviour, and a soul to save, and some that laugh at both; there are Hobbian protestants, Muggletonian protestants, Socinian protestants, quaker protestants, rebel protestants, protestants of $4 \mathrm{I}$, and protestants of 48. All or most of which are as different as popery itself from the true protestancy of the church of England.... Unless we derive the authority of that religion that is by law established from the antecedent law of Christ, we may quickly be (as we are in a fair way to be) a reformed church of protestant atheists, that is, a church without a religion ${ }^{2}$.

His last paragraphs are an apology for the foreign reformed churches :

God forbid we should be so uncharitable as to go about to unchurch them, or renounce brotherly communion with them, or to think that our blessed Saviour should withdraw the promise of his grace and protection from them.... Neither beside this does it appear that they in the least refuse communion with the episcopal church, which is the main charge against our separatists ${ }^{3}$.

${ }^{1}$ The Case of the Church, etc., p. $252 . \quad{ }^{2}$ Ibid. p. 263.

3 Ibid. pp. 268 foll. 


\section{The Restoration Period}

It is only prejudice, or want of opportunity, or want of information, that makes them to have no bishops.

In another book, printed in 1683, Parker gave an Account of the Government of the Christian Church for the first six hundred years, going more fully into the history and development of the hierarchy.

One of the most successful religious books of the restoration period was John Scott's Christian Life from its Beginning to its Consummation in Glory. It was first published in I68I, but passed rapidly through a great number of editions. In the second part of this work Scott treats of the nature and constitution of Christ's kingdom, which he confesses to extend a great deal farther than the church; yet " the church is more peculiarly his kingdom, as consisting of that part of the world which owns and acknowledges his authority, makes a visible profession of fealty to him, and submission to his laws and regulations."

Scott gives this definition of the church :

It is the one universal society of all Christian people, incorporated by the new covenant in baptism, under Jesus Christ its supreme Head, and distributed under lawful governors and pastors into particular churches, holding communion with each other in all the essentials of Christian faith, and worship, and discipline ${ }^{\mathbf{1}}$.

The different parts of this definition are carefully and lucidly worked out, one after another. Scott's description of what is meant by holding communion with each other is well worth reading:

1 Christian Life from its Beginning to its Consummation in Glory, 9th ed. I729, p. 43I. 


\section{The Restoration Period}

I mean, owning each other as parts of the same body, and admitting each others' members, as occasion serves, into actual communion with them in all their religious offices.... All the communion which they are obliged to, as they are similar parts and distributions of the catholic church, is that they should not divide into separate churches, so as to exclude each others' members from communicating in each others' worship, whenever they have occasion to travel from one church to another. For so long as there is no rupture between distant churches, no declared disowning of each other, no express refusal of any act of communion to each others' members, they may be truly said to maintain all necessary communion with each other.

\section{That communion is necessary, Scott shows by four considerations :}

First, that by baptism, as was showed before, all Christian people are made members of the catholic church, and by being made members of it they are all obliged to communicate with it ; for how can they act as parts of the whole, that hold no communication with the whole? They who are members of any society have not only right to communicate in all the common benefits of it, but also an obligation to communicate in all common offices of it.... And then secondly, it is farther to be considered that, the catholic church being all distributed into particular churches, we can no otherwise communicate with it than by communicating with some particular church; for how can we communicate with the whole, that is all distributed into parts, without communicating with some part of the whole?... For how can we be in communion with the whole body, when we are out of communion with all the parts, unless we can find...some universal church without all particular churches? But then thirdly,... as we cannot communicate with the universal church without communicating with some particular one, so neither do we communicate with the universal church by communicating with any particular one, unless that particular M. 
one be in communion with the church universal.... It is as possible for a finger to communicate with a body by being joined to an arm that is separated from the body, as it is for a Christian to communicate with the church catholic by being joined to a church that is separate from the church catholic. But then fourthly and lastly, there is no particular church can be in communion with the catholic, that separates itself from the communion of any particular church that is in communion with the catholic. For they who separate from any part of any whole, must necessarily separate from the whole, because the whole is nothing but all the parts together.... When two churches separate from one another, it must be either because the one requires such terms of communion as are not catholic, or because the other refuses such terms as are ${ }^{1}$.

When he comes to the communion in discipline, with which his definition ends, Scott says plainly:

Though the particular modes and circumstances of Christian government and discipline are not determined by divine institution, but left for the most part free to the prudent ordering and disposal of the governours of particular churches; yet there is a standing form of government and discipline in the church, instituted by our Saviour himself, which, as I shall show hereafter, is this, that there should be an episcopacy, or order of men, authorised in a continued succession from the apostles (who were authorized by himself) to oversee and govern all those particular churches into which the church catholic should be hereafter distributed; to ordain inferior ministers to teach, [etc.]... and having ordained them, to guide and direct them in the discharge of their functions.... These things therefore being all of divine institution are the essentials of Christian government and discipline, in which all Christian churches are obliged to communicate with each other. And this being the standing

1 Christian Life from its Beginning to its Consummation in Glory, pp. 439 foll. 


\section{The Restoration Period}

government and discipline of the catholic church, no particular church or community of Christians can refuse to communicate in it, without dividing itself from the communion of the church catholic ${ }^{1}$.

\section{This seems to cut off all non-episcopalians; but Scott draws distinctions :}

I say " refuse to communicate in it," because it is possible for a church to be without this government and discipline, which yet doth neither refuse it, nor the communion of any other church for the sake of it. A church may be debarred of it by unavoidable necessities in despite of its power and against its consent; and under this circumstance I can by no means think such a church to be separated from the church catholic. It is indeed an imperfect and defective part of the catholic church ; and if this defect of it be any way owing to its own negligence, it is a very great fault in it, as well as an unhappiness. But though this instituted government is necessary to the perfection of a church, yet it doth not therefore follow that it is necessary to the being of it.... Whenever the divine providence doth by unavoidable necessity deprive any church of its episcopacy, it thereby, for the present at least, and whilst the necessity continues, releases it from the obligation of the institution of episcopacy, and allows it to administer its government and discipline by a parity of presbyters. And therefore so long as it doth not renounce the episcopacy, but still continues in community with other churches that enjoy it, it ought to be looked upon and communicated with as a true member, though a maimed one, of the church catholic ${ }^{2}$.

Yet, Scott adds, " it is a plain case that if it rejects the episcopacy, and separates from the communion of it, it thereby wholly divides itself from the communion of the catholic church."

1 Christian Life from its Beginning to its Consummation in Glory, p. 443 .

2 Ibid. pp. 443 foll. 
In a subsequent section of the book Scott endeavours to prove that the episcopal government is the true form of government instituted by our Saviour, both from his own action, and from the practice of the apostles, and the punctual conformity of the primitive church to both. There is nothing very remarkable in his treatnient of this-thesis, unless it be for his full and vigorous criticism of Jerome's theory of the episcopate :

This therefore being removed, which is the main, and indeed the only considerable, objection against the universal conformity of the primitive church to the episcopal government, it remains that if any credit may be given either to those writers that lived in the apostolic age, or to those who immediately succeeded them, it is evident from their unanimous testimonies that the episcopacy is nothing else but only the apostolical superiority derived from the hands of the apostles in a continued succession from one generation to another ${ }^{1}$.

Naturally, the ordination of others is a principal part of this exalted ministry :

This commission therefore of sending others being originally transferred by our Saviour upon the apostolic order, no others could have right to transfer it to others, but only such as were admitted of that order; none could give it to others, but only those to whom Christ gave it ; and therefore, since Christ gave it to none but apostles, none but apostles could derive it; and accordingly we find in scripture that all ecclesiastic commissions were either given by the hands of some of those first apostles who received their commission immediately from our Saviour, or else by some of those secondary apostles that were admitted into

1 Christian Life from its Beginning to its Consummation in Glory, pp. $4^{8} 4$ foll. 


\section{The Restoration Period}

apostolic orders by them ; which secondary apostles, as was shown before, were the same with those whom we now call bishops ${ }^{1}$.

Thomas Pierce, Dean of Salisbury, in his Pacificatorium Orthodoxae Theologiae Corpusculum (I683), sums up one section of the chapter de Ministris Ecclesiasticis in the words :

Tres sunt duntaxat jure divino et apostolico [ordines], in aeternum duraturi ${ }^{2}$.

Explaining the language of Article XXIII about those who have the right to send ministers into the Lord's vineyard, after dismissing such opinions as that it belongs to the civil power, or to the people, to the pope, or to the bishops as his commissioners, Pierce says :

Ecclesia vero Anglicana episcopis omnibus ex aequo, sub pontifice maximo Jesu Christo, ... hanc delegatam potestatem de jure tribuit.

But he adds :

Ita tamen et eatenus ut sine presbyteris assistentibus sacros ordines non conferant, manus nemini imponant. Episcopos et presbyteros simul esse adhibendos in legitima ordinatione (si fieri queat) probant scripturae, confirmat ratio ${ }^{3}$.

He pays elaborate compliments to the foreign protestant ministers, who have the inward vocation, and the outward also:

1 Christian Life from its Beginning to its Consummation in Glory, p. $49 \mathrm{r}$.

${ }^{2}$ Pacificatorium Orthodoxae Theologiae Corpusculum (ed. 2), p. $25^{8}$.

3 Ibid. pp. 269 foll. 
Qualem et clerus et magistratus et populus conjunctim conferre possunt, sed non omnino nisi ex voto quam vulgo vocamus episcopalem, quali gaudemus nosmetipsi, fratresque nostros extraneos gaudere posse exoptamus. Ad illos, inquam, quod attinet, distinguunt viri longe doctissimi inter liberam et depressam ecclesiam Dei. Itemque censent distinguendum inter vocationem ab omni parte legitimam, et ex aliqua parte mutilam, sed non absolute vitiatam, aut prorsus nullam. In ecclesia plene libera, qualis est noster Anglicana, et extra casum necessitatis, nullum habet locum vocatio mutila neque materiam apologiae; quae in ecclesia

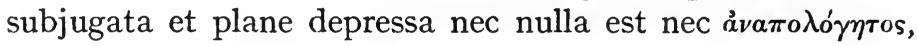
sed duris quibusdam variisque necessitatibus circumsepta et circumstantiis, et accepta est Deo, et piis hominibus suspicienda.

\section{He felt however that warnings were needed :}

Cavendum est igitur vigilantissime in ecclesiis exoticis, sed maximam partem reformatis, ne sincerae religionis exercitio propter defectum episcopatus omnibus numeris absoluti fraudetur populus omnino, quos Christus suo sanguine sibimetipsi acquisivit. Sed satius ducant e contra, pastores quos habent qualescunque, recta docentes auscultare, et sacramenta ab eis petere, eosque honore semper prosequi, quam aut ansam praebere aliquam, aut ullo pacto in causa esse, ut Christi religio aboleatur. Non tantummodo non negant, sed animitus contendunt, qui ecclesiis quos vocant veriverbio evangelicis praeficiuntur, ritum ordinationis nequaquam esse omittendum, sed extra casum necessitatis semper adhibendum esse in ministris ecclesiae constituendis ${ }^{1}$.

Unfortunately the writer was hardly the person to make peace between contending parties. The peacemaker was better seen in a man like Timothy

1 Pacificatorium Orthodoxae Theologiae Corpusculum, p. 274. 
Puller, who in I679 published his Moderation of the Church of England ${ }^{1}$.

Our church maintains and preserves those orders of ministers in the church, bishops, priests and deacons, which are truly primitive; without the additional train which the church of Rome makes necessary, even seven kinds of orders suitable to their number of sacraments, and with much the like necessity that the followers of the Geneva-government appoint their lay-elders. The power of orders consisteth partly in preaching the word and other offices of public worship, common to bishops with other ministers ; partly in ordaining priests and deacons, admitting them to particular cures, and other things of that nature, proper to them [bishops] alone. The government of the church according to these orders...hath an excellent temper between an ecclesiastical monarchy, which the church of Rome asserts, ... and between such democracy and populacy as is held in the independent and presbyterian party ${ }^{2}$.

[Our church] imitates the moderation of the whole catholic church in being against the rebaptizing of any who have had the essentials of baptism, and also against the reordination of those who keep the essentials of ordination ; and of such churches where bishops cannot be had we use all moderation of judgment. Yet where our constitution requires ordination by bishops, it is at liberty not to make use of their ministry who peremptorily refuse the ordination of our bishops, or who would in a settled church and kingdom set up a church government in opposition to the bishops who ordained them before ${ }^{3}$.

\section{Puller says that:}

The excellent temper of our church is abundantly justified in that universal concord and friendship it desires to maintain

${ }^{1}$ Reprinted in 1843 by R. Eden, afterwards Bishop of Moray and Ross.

2 Moderation of the Church of England (ed. I843), p. 193.

3 Ibid. p. 195. 
with all, so far as may be done lawfully.... With the whole church throughout the world, and every part thereof to whom her communion is not displeasing, our church in desire and endeavour doth maintain all inward and outward agreement she can; in affections and behaviour also so approving herself that it is manifest she unwillingly differs from any, and no more than needs must ${ }^{\mathbf{1}}$.

He quotes in proof of this the famous thirtieth canon.

Neither did our church of England ever yet oppose itself to any lawful ecclesiastical authority; which yet is inseparably of the essence of schism; but on the contrary, according to a singular moderation and charity, it doth open its bosom to every genuine son of the true catholic church, of what denomination soever.

When it has refused to communicate with others in some particular unwarrantable usages, this was

under express protestation; from whence was occasioned the moderate and innocent title of Protestants, for protesting against the edict at Worms, which was for restoring all things as they were without reformation. By which protestation all scandal of schism is taken away, and desire of reconciliation is publicly testified, not as of absolute necessity, but for the sake of catholic unity; by which protestation a right is vindicated from the usurpation of the church of Rome ${ }^{2}$.

She recognises the freedom of other churches :

M. Amyrald well observes the friendly moderation of the English and French protestants; when they are in each other's countries, they readily join themselves with the communion of the churches they are in ${ }^{3}$.

1 Moderation of the Church of England, p. 256.

${ }^{2}$ Ibid. p. $257 . \quad 3$ Ibid. p. 259. 


\section{The Restoration Period}

She has a special solicitude for " the afflicted Greek church, to whom as she hath opportunity, she hath testified a great commiseration, a most pious affection, and a great esteem."

Some of the Greek bishops and priests are allowed among us the celebrating holy mysteries according to their own rites ${ }^{\mathbf{1}}$.

It is the same with the reformed churches. She seeks no dominion over them :

Other churches have not been by the church of England despised, if in sundry instances they have not arrived unto her perfection in purity of doctrine and order of discipline... . Although our church of England hath had the peculiar happiness of a monarchical reformation and retains the blessing of episcopal government, yet such is the moderation of our church, she imputes the want of the same in other reformed churches, not so much to any fault of those churches themselves, but rather attributes it to the injury of the times ${ }^{2}$.

The "lenity and benignity" of our church is no less shown towards " our domestic dissenters."

In confuting opinions our church always spares the persons, how severe so ever she is upon the error ; because in the divisions of hearts that are in the world, it is certain some good may dissent. So moderate also and just is our church, she is far from deterring others from her communion by branding any with the note of heresy, unless upon just reason and cause, distinguishing also between a heretic and those who are by heretics seduced ${ }^{3}$.

\section{In these ways she is qualified}

to be the best and most proper for arbitrating and reconciling the present differences of Christendom ;... neither will any, I hope, have the worse opinion of our church,

1 Moderation of the Church of England, p. 260.

2 Ibid. p. 26r. $\quad{ }^{3}$ Ibid. p. 246. 
because Grotius thought the church of England " a right medium of reconciliation," whose "pacificatory design" Mr Baxter took to be " one of the most blessed noble works that any man can be employed in ${ }^{1}$."

And whereas they commonly say that the church of England, and the chief of her communion, are unwilling to allow any pacification with, or concessions to, protestant dissenters, as may be reasonable for public concord, we answer, they are utterly mistaken in saying so, for beside that the conditions of communion with our church are very equal and just, we may presume to say also...there is no doubt but our church would gladly, in such things as she might, remit of what she judgeth otherwise expedient, for the ends of peace and universal concord, if she could be assured any reasonable concessions should have that effect, as might suit with the true honour of God and the real good of the church $^{2}$.

It is not, of course, asserted that the view of episcopacy held by Patrick and the others mentioned in this chapter were universally held. They were not held, for example, by Herbert Croft, Bishop of Hereford. But Croft was something of a freak. At the age of 13 he joined the Roman communion, but was soon brought back again. He had not been known as an author, but in 1675 , when he was 72 years old, he made his début in an anonymous tract, called The Naked Truth, by " an humble moderator." It professed to be the work of what would now be called the man in the street, or the average man. With clever irony it suggested solvents to break up the pretensions of the accepted theology. It advocated the surrender of all the contested rites and

1 Moderation of the Church of England, p. 248.

2 Ibid. pp. 254 foll. 


\section{The Restoration Period}

ceremonies; and above all, while maintaining episcopacy, it decried and derided the claims that were made for the system.

The moderator opens with an address to parliament on the failure of their well-intended legislation :

My lords and noble gentlemen, you have fully expressed your zeal to God and his church in making laws for unity in faith and uniformity in discipline; for as our Saviour said, "A kingdom divided against itself cannot stand," so the same may certainly be said of a church, the reason being the same for both. And I call the searcher of all hearts, the God of life and death, to witness that I would most readily, yea most joyfully, sacrifice all I have in this world, my life and all, that all nonconformists were reduced to our church. But it falls out most sadly that your laws have not the desired effect. Our church is more and more divided.

He professes the utmost loyalty to the episcopal régime:

Whoever unbiassed reads the scripture, thence proceeds to the first Christian writers, and so goes on from age to age, can't doubt but that the church was always governed by bishops, that is, by one elder, or presbyter, or president, or whatever else you please to call him, set over the rest of the clergy with authority to ordain, to exhort, to rebuke, to judge and censure, as he found cause. No other form of government is mentioned by any authority for fifteen hundred years from the apostles downwards.... And therefore nothing but necessity, if that, can excuse those who first set up another form of government. To their own Master let them stand or fall; I will not presume to censure them. I will only say, that from the beginning it was not so ; and I thank God 'tis not so with us, but as it was in the beginning, so it is now with us, and ever shall be, I trust in God. Amen 1 .

${ }^{1}$ Naked Truth, pp. 33 foll. 


\section{Then comes the sceptical demurrer :}

But notwithstanding all this, yet 'tis very much to be doubted whether they were of any distinct superior order from and above the presbyters, or one of the same order set over the rest ${ }^{1}$.

The moderator requires much to convince him :

I shall always most readily submit to the interpretation of the primitive and universal church. I require both primitive and universal ; for I showed before that in matters of faith there were some errors very primitive, yet not continued by the universal church, but rejected in succeeding ages $^{2}$.

He insists upon the practical importance of the question :

This is not a matter of any indifferency, but of vast and dangerous consequence.... If bishops be of such a superior and distinct order as you pretend [i.e. assert], if the power of ordination be inherent in them only, then, where no bishop, no true priests ordained; where no priests, no sacraments; where no sacraments, no church. Wherefore I humbly beseech you, be not too positive in this point, lest thereby you do not only condemn all the reformed churches, but the scripture and St Paul also ${ }^{3}$.

As he advances, the moderator becomes more positive himself :

Yet I cannot by any means consent to them who would have episcopacy to be a distinct order,... nor can I think the ordination of a priest made by priests invalid; for though it ought not to be done, but only of necessity, yet being done 'tis valid, and certainly may, without any crime, by any priest by shipwreck or any such chance cast into a country
1 Naked Truth, pp. 33 foll.
${ }^{2}$ Ibid.p. 42.
3 Ibid. p. 45. 


\section{The Restoration Period}

where there were none commissionated to ordain.... Doubtless to ordain out of order is better than no ordination.... Yet where order can possibly be observed, it ought to be; for God is the God of order ${ }^{1}$.

Cosin's factum valet has come home to England ${ }^{2}$.

The venerable man who vacated the see of Canterbury in I688, rather than break the oath which he had taken to James II, belonged by birth and fashion of mind to an earlier generation. Sancroft was Cosin's chaplain, and on the great occasion in 1660 when Cosin, with no fewer than six others, was consecrated bishop, Sancroft preached the sermon. Although disfigured by the style which Andrewes had made fashionable, but which few besides Andrewes could make agreeable, the sermon was not unworthy of the day. It was on Titus i. 5, "For this cause left I thee in Crete," etc. In this verse

the man not blind with ignorance, nor bleared with passion; may see distinctly the face of the primitive church, in that golden age of the apostles; the platform of her government; the beautiful order of her hierarchy; the original and derivation of her chief officers, and their subordination both to one another and to Christ, the great bishop of our souls, in the last resort; together with the manage and direction of the most important acts of the government, both in point of ordination and jurisdiction too. For here we have... elders, that is, bishops (as shall be showed in due time) disposed of city by city, in every city one ; these bishops both ordained and ordered, constituted and

1 Naked Truth, p. $4^{8}$.

2 Croft is the first English writer, so far as I am aware, to mention the Jesuit Petavius and his theory of presbyters ordained with special super-presbyteral powers. 
- corrected, created and governed by Titus alone; and so he, in right of the premises, no other than metropolitan or archbishop there.

The preacher apostrophizes the men " who not long since pretended to reform us according to the best examples," and says :

If really you be in quest of the best examples of modelling a church, you may certainly find here as fair and as pure ideas, and as well worth your imitation, as the more modern platform can afford you,-which I have reason to believe the famous author of it [Calvin] intended not at first a pattern to other churches, but an expedient to serve the present exigency of his own in a juncture scarce capable of anything better, and which, I am persuaded, the learnedest and wisest and most pious of his followers would gladly relinquish for something more perfect and primitive, would the necessities of their present condition (which have no law, but much of excuse for those that really lie under them) permit them the happiness of so blessed an exchange, which God in mercy send them ${ }^{1}$.

Letters of Sancroft's at a later time testify to his interest in the foreign churches, and at the same time to his unwillingness to lend himself to anything like intrigues among them. To Covel, the learned chaplain at the Hague, he wrote in I684, declining to join without clearer information in promoting a league for the defence of the protestant cause, but saying:

There are not, it may be, many persons who have a deeper or more tender resentment [i.e. sense] than I have of the sad and deplorable state of the reformed churches in some parts of the continent of Europe ; and I should count

1 D'Oyley's Life of Sancroft (ed. 2), pp. 339, 359. 
it my joy and the crown of my rejoicing, if I could contribute anything, besides my daily prayers ut videat Deus et requirat, towards restoring and advancing them to a yet better condition' ${ }^{\mathbf{1}}$.

He interested himself in well-disposed foreign protestants who came to England:

There is a stranger who has been some time among us, he writes to the Bishop of St Asaph, John Sesbaldus Fabricius, a man of very good learning, humble, and modest, one that loves our church well, and hath written in defence of it, and thereby created himself enemies both among our dissenters here and his own countrymen, who have thereupon divested him of the livelihood he had there before, so that I have now reason to fear he is in want ${ }^{2}$.

He begs the bishop to bestow upon him " one of the many sinecures" within his patronage.

Towards the protestant dissenters at home Sancroft always expressed himself charitably; and when the great occasion of his life came, and he and the other six bishops were acquitted, he took occasion to speak of them in the admonition which he issued to the clergy :

That they also walk in wisdom towards those that are not of our communion; and if there be in their parishes any such, that they neglect not frequently to confer with them in the spirit of meekness, seeking by all good ways and means to gain and win them over to our communion: more especially, that they have a very tender regard to our brethren the protestant dissenters; that upon occasion offered they visit them at their houses, and receive them kindly at their own, and treat them fairly wherever they meet them, discoursing calmly and civilly with them; persuading them (if it may be) to a full compliance with our church, or at

${ }^{1}$ Life of Sancroft, p. 118.

${ }^{2}$ Ibid. p. ro8. 
least that " whereto we have already attained, we may all walk by the same rule, and mind the same thing." And in order hereunto that they take all opportunities of assuring and convincing them that the bishops of this church are really and sincerely irreconcileable enemies to the errors... of the church of Rome, and that the very unkind jealousies which some have had of us to the contrary were altogether groundless. And in the last place, that they warmly and most affectionately exhort them to join with us in daily fervent prayer to the God of peace for the universal blessed union of all reformed churches both at home and abroad against our common enemies, that all they who do confess the holy name of our dear Lord, and do agree in the truth of his holy word, may also meet in one holy communion, and live in perfect unity and godly love ${ }^{\mathbf{1}}$.

Two points may be observed in this admonition. It is clear that Sancroft did not consider that the church of England was as yet in union or communion with the various bodies in question: that was still an object to be prayed for. On the other hand, if his language is to be pressed, he is perhaps the first Anglican divine to confer upon the protestant bodies in England the title of " reformed churches" : but possibly he did not intend so much by his expression "the union of all reformed churches at home and abroad."

It is well known that Sancroft followed up this admonition by setting on foot one of those schemes of comprehension of which we shall have to make mention again. At the time of Sacheverell's trial, Wake, then soon to succeed to Sancroft's throne, gave an account of this measure.

1 Life of Sancroft, p. 196. 
The time was towards the end of the late unhappy reign, when we were in the height of our labours in defending the church of England against the assaults of popery, and thought of nothing else. At this time, that wise prelate [Sancroft], foreseeing a revolution such as that which soon after occurred, began to consider how utterly unprepared they had been at the restoration of King Charles II to settle many things to the advantage of the church, and what a happy opportunity had been lost, for want of such previous care, for its more perfect establishment. It was visible to all the nation that the more moderate dissenters were generally so well satisfied with that stand which our divines had made against popery.... as to express an unusual readiness to come within the pale of the church. And it was therefore thought worth while...to consider... what might be done to gain the more moderate dissenters without doing any prejudice to ourselves. The scheme was laid out, and the several parts of it were committed, not only with the approbation but by the direction of that great prelate, to such of our divines as were thought most worthy to be entrusted with it. His Grace took one part himself... The design was in short this: to improve and if possible amend our discipline; to review and enlarge our liturgy, by correcting some things, by adding others, and...by omitting some few ceremonies... so as not to make them of necessity binding on those who had conscientious scruples respecting them.... And if things alterable be altered upon the grounds of prudence and charity, ... whilst the doctrine, government, and worship of the church remain entire in all the substantial parts of them, we have all reason to believe that this will be so far from injuring the church, that on the contrary it will receive a great benefit from it ${ }^{1}$.

The account of episcopacy in England at the restoration would be sadly incomplete if no reference were made to the reintroduction of it (for the second

' Quoted by D'Oyley, ut supra, pp. 197 foll.

M. 
time) into Scotland, and especially to the views and action of Archbishop Leighton. On such a man it is a temptation to dwell too long. "Bred up," as Burnet says, "with the greatest aversion imaginable to the whole frame of the church of England," he received presbyterian ordination, but " he soon came to see into the follies of the presbyterians." By and by " he entered into a great correspondence with many of the episcopal party, and did wholly separate himself from the presbyterians ${ }^{1}$."

When the time fixed for the consecration of the bishops of Scotland came on, the English bishops, finding that Sharp and Leighton had not episcopal ordination as priests and deacons,... .they stood upon it that they must be ordained, first deacons, and then priests. Sharp was very uneasy at this, and remembered them of what had happened when King James had set up episcopacy ${ }^{2} \ldots$.. But the late war, and the disputes during that time, had raised these controversies higher, and brought men to stricter notions, and to maintain them with more fierceness... . The English bishops did also say that by the late act of uniformity that matter was more positively settled than it had been before, so that they could not legally consecrate any but those who were... made first priests and deacons. They also made this difference between the present time and King James's: for then the Scots were only in an imperfect state, having never had bishops among them since the reformation; so in such a state of things, in which they had been under a real necessity, it was reasonable to allow of their orders, how defective soever: but that of late they had been in a state of schism, had revolted from their bishops, and had thrown off that order; so that orders given in such a wilful opposition to the whole constitution

1 Burnet's Own Time (ed. 1724), vol. I. pp. 135 foll.

2 See above, p. 70 foll. 
of the primitive church was a thing of another nature. They were positive in the point, and would not dispense with it. Sharp stuck more at it than could have been expected from a man that had swallowed down greater matters. Leighton did not stand much upon it. He did not think orders given without bishops were null and void. He thought the forms of government were not settled by such positive laws as were unalterable, but only by apostolical practices, which, as he thought, authorised episcopacy as the best form. Yet he did not think it necessary to the being of a church. But he thought that every church might make such rules of ordination as they pleased, and that they might reordain all that came to them from any other church, and that the reordaining a priest ordained in another church imported no more but that they received him into orders according to their rules, and did not infer [i.e. involve] the annulling the orders he had formerly received. These two were upon this privately ordained deacons and priests. And then all the four were consecrated publicly in the abbey of Westminster ${ }^{1}$.

Of the tragical chapter of history thus commenced it is unnecessary to write. No attempt was made in Scotland to impose the condition of episcopal ordination upon the existing clergy in general. Leighton sought to commend episcopacy in a form modelled upon Usher's " reduction," such as Baxter and the English presbyterians professed a willingness to receive.

The question between us, he wrote, is not concerning bishops governing absolutely by themselves and their delegates, but concerning bishops governing in conjunction with presbyters in presbyteries and synods: of which we affirm that it is neither contrary to the scriptures nor the

1 Burnet's Own Time, vol. r. pp. 139 foll. 
example of the primitive church, but most agreeable to both. If any think otherwise, let them produce their evidences of scripture and antiquity.... If they shall say they are not against a fixed president or bishop, or call him what you will, ... but that the question is about their power, then we beg that it may be so.... We trust we shall be found not at all desirous to usurp or effect any undue power, but rather to abate of that power which is reasonable and conform even to primitive episcopacy than that a schism should continue in this church upon this score ${ }^{1}$.

It was in vain. The presbyterians " hated him most of all his fraternity, in respect he drew many into a kindness for episcopacy by his exemplary life, rather than debates2." In I674 he finally withdrew from the struggle, and in retirement in Sussex awaited those "shadows of the evening" for which he longed, when there would be rest "from all these poor childish trifling contests ${ }^{3}$." foll.

1 Leighton's Whole Works (ed. Pearson, 1825), vol. I. pp. clxxxix

2 Mackenzie's History of Scotland, p. I6I.

3 Whole Works, vol. I. p. clxxxvii. 


\section{CHAPTER V}

THE REVOLUTION AND SINCE

WiTH the ejection of the nonjurors, and Tillotson's accession to the throne of Canterbury, the church of England began to pass into a new phase of thought and feeling. Its characteristic was the desire for comprehension on the one hand, and toleration on the other. Each of the two words requires some explanation.

Toleration meant the abandonment of a lofty but impossible ideal. The ideal was the union of all members of the civil commonwealth in a single religious organization. This had been the aim, and to a certain extent the achievement, of the early and mediaeval catholicism. There was always the standing exception of the Jews-; but they were not looked upon as actual citizens, and their position was always precarious. There were Lollards and the like; but their existence was never tolerated. The reformation made no difference in this respect. It was expected and demanded that all citizens should adhere to the reformed church as they had done, or were supposed to do, to the unreformed. They were not to hold aloof under pretext of loyalty to Rome ; they were 


\section{The Revolution and Since}

not to form new and detached communities on " evangelical " principles. All were to be one. The ideal was still unchanged when episcopacy and the prayer-book were swept away. The presbyterian party were at least as earnest in the maintenance of it as their predecessors had been, though the independent or congregational principle allowed in theory of somewhat more latitude. The restoration with its act of uniformity prescribed, not for a majority of the nation, who belonged by conviction to the church of England, but for England without exception. Every Englishman was reckoned to belong to the church, and was required to comply with its rules. Church and state alike took this view.

But the attempt was a failure. Not all English Christians would conform to the ways of the recognized church. The Romanists would not. Many protestants would not. The protestants who would not, were sharply divided into two classes. They were the nonconformists on one side, and the separatists on the other.

The nonconformists were strictly, as they described themselves, nonconforming members of the church of England. These men were for the most part presbyterian by preference, but by no means all. They objected so strongly to certain parts of church worship and practice that they could not join in them, but they abhorred the thought of cutting themselves off from the church of the majority. Many of them would occasionally go to church, and even communicate. At the outset they formed no rival 
organization. They ordained no ministers. Though they held separate meetings for prayer and preaching, they refused to set up a schismatic communion. Baxter says that some nonconformists-evidently meaning himself-had gone for I8 years without administering the sacrament ${ }^{1}$. At first they would not hold their meetings at the same time as the church service, though gradually they broke away from this rule 2 . Their hope was that ultimately things would change, and their views be accepted. by the church at large, and that then they would resume their place openly in the communion of the church. For the time being, they were ready to suffer many privations rather than create a schism, which they considered to be a crime and a sin.

The separatists denied that they were in a state of schism, but they did so on other grounds. Their contention was that what we call the church of England had ceased to be a Christian church altogether. It was anti-Christian, like Rome. They denounced the attitude of the nonconformists almost more vehemently than that of the conforming churchman. They assailed Baxter more fiercely than they assailed the prelates. The baptists pronounced a definite excommunication upon any one who attended church, whatever the pretext might be. These men

1 Baxter's Plea for Peace, p. 243, quoted by Stillingfleet in Works, vol. II. p. 599 (second series of pages).

${ }^{2}$ Patrick's Friendly Debate, p. 27 I (Works, vol. v.). The methodists, even in the conference of 1795 which definitely separated them from the church, passed a rule not to administer the sacrament on days when it was administered in the parish church. 
claimed that there was no other church in England but their churches, and therefore there was no schism in the erection of their new system.

Weary of endeavouring to coerce into union men who refused to be united, authorities in church and state came gradually to accept the notion of toleration,- - that is, of putting up with the existence of other religious communities besides the church. In I689 the legislature passed the act which is commonly called the Toleration Act, but which describes itself as " an act for exempting their Majesties' protestant subjects dissenting from the church of England from the penalties of certain laws." It did not apply to Romanists. It did not apply to those who denied the doctrine of the Trinity. The rest could obtain the benefit of the act on registering themselves and their places of worship. This was the best, the only thing, to be done under the circumstances; but it was the relinquishment of a long cherished design. A dissenting historian says truly that "from the moment that William gave his assent to the act [the church of England] ceased to be national in the sense in which it had been so before. It could no longer claim all Englishmen as, by sovereign right, worshippers within its pale; it gave legalized scope for differences of religious action ${ }^{\mathbf{1}}$." And, the historian might have added, it thereby obtained a greater measure of freedom for itself: it was no longer obliged to study so much the feelings and opinions of men who had ceased even nominally to belong to it.

1 Stoughton Religion in England, vol. v. p. 98. 
But it was impossible, of course, for the church to acquiesce in the loss of a great number of baptized and earnest English Christians; and the natural accompaniment of toleration for those who altogether refused to have any connexion with the church was an effort after comprehension, that is, to make such relaxations of the church's rules as would enable men of less hostile sentiments to enter the church again. A whole series of schemes of comprehension arose, one after another. Sometimes practices which gave offence were to be abandoned. Sometimes they were to be made optional. The terms on which ministers might be received were to be made elastic. But there are one or two points to be observed about all the schemes of comprehension that were ever put forward. One is that the comprehension was for individuals, not for communities. There was never any proposal to include within the church any organization which would continue after inclusion to have an organization of its own ${ }^{1}$. The persons comprehended were to become in every way churchmen, and churchmen only, though churchmen indulged in various details and usages. Another point is that however easy it was made for existing ministers, insufficiently ordained (from the church point of view), to be received into the ministry, no scheme of comprehension ever proposed that for the future there should be any method of ordination except the

$1{ }^{\circ}$ The proposed arrangement with the Moravians was a partial exception to this rule, but it formed no part of a general scheme of comprehension. 
method prescribed in the prayer-book. No one ever suggested that presbyterian ordination should be put side by side with episcopal ordination. Comprehension was absorption.

Tillotson was naturally disposed to compromise. Tillotson commenced his career under puritan influences, but soon passed into the society of the Cambridge Platonists, who enlarged his conceptions, though he was never one of them. Presumably he received some kind of uncanonical ordination in the commonwealth period, for he performed the office of chaplain to an eminent officer of the commonwealth ${ }^{\mathbf{1}}$. But when the restoration was imminent, Tillotson was among the multitude of ministers who thronged to be ordained by old Bishop Sydserf of Galloway. He attended the Savoy Conference, however, as a silent adherent of the puritan commissioners, submitting directly afterwards to the act of uniformity.

There can be no doubt that his attachment to the church was sincere, but " his tender method of treating with dissenters," Birch says, " and his endeavours to unite all protestants amongst themselves, were represented as a want of zeal in the cause of the church, and an inclination towards those who departed from it ${ }^{2}$."

He took a prominent part in the various comprehension schemes of the period.

The Dean's concern ${ }^{3}$ for the essence of pure and uncorrupted Christianity was attended with a proportionable

1 Birch's Life of Tillotson (2nd ed.), p. I7. 2 Ibid. p. 33.

${ }^{3} \mathrm{He}$ only became Dean of Canterbury in 1672 . 


\section{The Revolution and Since}

moderation of temper and principles with respect to the lesser differences amongst protestants, and especially those of our own country. Hence followed a constant desire in him of a more entire union of them, not only on account of the general advantage of it, but likewise of the particular one of forming a stronger barrier against the perpetual encroachments of the see of Rome. He joined therefore... in the treaty proposed by Sir Orlando Bridgman... about January $166 \frac{7}{8}$, and countenanced by the Lord Chief Baron Hale, for a comprehension of such of the dissenters as could be brought into the communion of the church, and for a toleration of the rest.....A project was prepared, consisting chiefly of those things which the King had promised by his declaration from Breda in the year 166o. Only in the point of reordination this temper [i.e. compromise] was proposed, that those who had presbyterian ordination should be received to serve in the church by an imposition of hands of the bishop, with this or the like form of words, Take thou authority to preach the word of God, and to minister the sacraments in any congregation of the church of England where thou shalt be lawfully appointed thereunto ; an expedient much of that nature having been practised and allowed of in the case of the Catharists and Meletians, as appears from the eighth canon of the Nicene council ${ }^{1}$.

The scheme proved abortive. The House of Commons would not hear of it. But Tillotson clung to his project. He is not known to have had a share in the scheme set on foot by Archbishop Sancroft, though he was certainly consulted by the archbishop

1 Life of Tillotson, p. 42. Baxter wished the words to run, "Take thou legal authority," etc., and this was inserted in the bill. He also proposed that all such ministers should have leave to "give in their profession that they renounce' not their ordination, nor take it for a nullity, and that they take this as the magistrate's license and confirmation." See Stoughton Religion in England, vol. III. pp. 374 foll. 
in the proceedings which led up to it. As soon as William and Mary came to the throne, he threw himself heartily into a new and more celebrated scheme of comprehension. His biographer prints a paper of " concessions which will probably be made by the church of England for the union of protestants, which I" - the paper is in Tillotson's hand- "sent to the Earl of Portland by Dr Stillingfleet, Sept. I3, I689." Among these concessions, the fifth is :

That for the future those who have been ordained in any of the foreign reformed churches be not required to be reordained here to render them capable of preferment in this church.

\section{The sixth is :}

That for the future none be capable of any ecclesiastical benefice or preferment in the church of England that shall be ordained in England otherwise than by bishops. And that those who have been ordained only by presbyters shall not be compelled to renounce their former ordination. But because many have [doubted], and do still doubt, of the validity of such ordination where episcopal ordination may be had and is by law required, it shall be sufficient for such persons to receive ordination from a bishop in this or the like form : If thou art not already ordained, I ordain thee, etc., as, in case a doubt be made of any one's baptism, it is appointed by the liturgy that he be baptized in this form, If thou art not baptized, I baptize thee, etc. ${ }^{1}$

This proposal was no doubt based upon the precedent set by Bishop Overall, as related above. White Kennett favours the belief that Tillotson was the author of $A$ Letter to a Friend relating to the 
present Convocation at Westminster, dated Nov. 27, I689, in which the writer, who professes to be a dissenter, says

This much I shall venture to say, that such amendments as these were, with such an allowance in the point of orders for ordination by presbyters as is made I3 Eliz. cap. I2, would in all probability have brought in two-thirds of the dissenters in England; which being done, and at the same time a liberty continued to such as could not be comprehended, would have been greater service than can easily be imagined ${ }^{1}$.

But the lower house of the Canterbury Convocation was by no means disposed, as a body, to adopt such measures.

It seemed to derogate from the dignity of the church of England to make any step towards the altering of her constitution till it did appear that the dissenters themselves did desire a reconcilement, and were ready to offer some proposals, or to accept of others ${ }^{2}$.

They refused to agree to an address which the upper house, then sadly depleted, had prepared, because it thanked the king for his zeal " for the protestant religion in general and the church of England in particular." They thought, Burnet says, " that this imported their owning some common union with the foreign protestants ${ }^{3}$ "' ; but they at last accepted a form of words which bears witness to the embarrassment under which it was composed, acknowledging the King's pious zeal and care

1 Complete History (ed. 1719), vol. III. p. 59I. With regard to the act of Elizabeth, see Appendix A below.

2 Ibid. pp. 591, 592.

3 Own Time, vol. II. p. 33. 
for the honour, peace, advantage, and establishment of the church of England; whereby we doubt not the interest of the protestant religion in all other protestant churches, which is dear to us, will be the better secured ${ }^{1}$.

That Tillotson was interested in the foreign churches is evident, though he was not much brought into contact with thern. Limborch dedicated to him, in I692, his Historia Inquisitionis, with an epistle which recognized the position of the church of England as " inter reformatas longe eminentissimae," and described the archbishop as in virtue of his office in it " ecclesiarum reformatarum defensorem." $\mathrm{He}$ was to be the leader, the spiritual father of them; under whose patronage all schisms and hatreds were to disappear. A famous anecdote connects the name of Tillotson with the French Huguenots. Charles II issued a brief for collections on behalf of the refugees who had suffered by the revocation of the edict of Nantes. Tillotson was then Dean of Canterbury :

1 Kennett, ut sup. p. 594. The account given in the Acts and Adjournments of the Convocation is as follows :

"The conference was managed chiefly between the Bishop of Salisbury [Burnet] and the Prolocutor [Jane]. The bishop urged that the church of England was not distinguished from other protestant churches but by its hierarchy and revenues, and that it [i.e. the term 'church of England '] was an equivocal expression, for if popery should prevail, it would be called the church of England still. To which the prolocutor answered that the church of England was distinguished by its doctrine, as it stands in the articles, liturgy, and homilies, as well as by its hierarchy, and that the term of protestant churches was much more equivocal, because Socinians, anabaptists, and quakers assumed that title, After this we heard no more reply" (Cardwell Conferences, p. 44.5). 
and the warmth of his zeal upon this occasion is evident from an answer which he returned to Dr Beveridge, one of the prebendaries of his cathedral, who from a coolness towards foreign protestants, or an unnecessary scruple with respect to forms even in affairs of weight and substance, had objected to the reading of one of these briefs there, as contrary to the rubric. The dean's reply was short and significant, " Doctor, Doctor, charity is above rubrics ${ }^{1 . "}$

It must be said to Tillotson's honour that his charity extended even to episcopalians in affliction, and that he made some efforts to render more tolerable the conditions under which they existed in Scotland ${ }^{2}$.

He was certainly urged to do so. A letter signed "V. M." was addressed to him in $\mathrm{I} 689$ by one who was in favour of large alterations in the prayer-book and in the customs of the church. It asked, "whether some expedients are not to be found out further to restore the credit of episcopacy among the vulgar, and redeem the reverence due to that (as I am persuaded) divine institution." Samples of such expedients are suggested, and finally the writer asks

Whether it would not be an act of charity in those reverend persons who meet by virtue of the present commission to make the distressed condition of a neighbour church [i.e. in Scotland] matter of their humble petition to those who are able to relieve her? Though some particular men have been guilty of imprudence and errors, that therefore a sacred order and a national church should be offered up as a sacrifice seems not very reasonable ${ }^{3}$.

1 Birch's Life, p. I22. There was, of course, nothing remarkable in Tillotson's exerting himself in the cause. Gunning, Ken, Hickes did so too.
2 Ibid. p. 28 I.
3 Cardwell Conferences pp. 454 foll. 
The commissioners sat. They discussed many things,-among them foreign reformed orders :

As for the ordination of foreign churches, it was urged by the Bishop of Salisbury [Burnet] that the church of England had allowed it, as in Du Moulin, Prebendary of Canterbury. Dr Beveridge replied that might be, for that it was not necessary where there was no cure of souls.

The Dean of Canterbury, Sharp, said "that he had heard laymen had been prebendaries, many."

But the bishop laid before them (I) the case of the Scotch bishops, who were consecrated bishops without being ordained priests. (2) It was said it was never made necessary till r66r. (3) That it was allowed in a case of necessity by those that were most violent, and that in positive institutions necessity ruled.

At last it was proposed to draw up a rubric to signify that the ordination in foreign churches was sufficient though imperfect ordination, and that those so ordained should be received by the imposition of the hands of the bishop only to officiate in the church of England.

As for dissenters the Bishop of Salisbury said " that it was a kind of necessity in our present circumstances," and that " in the ancient church, notwithstanding the canons, the Donatist bishops were admitted to be bishops in the same city with catholic bishops till vacancy, when the survivor should be bishop." It was finally determined (Drs Beveridge and Scott dissenting) to be hypothetically expressed ${ }^{\mathbf{1}}$.

1 IIth Session of the Royal Commissioners for the Revision of the Liturgy in 1689 (p. I02); quoted by Bp Phillpotts Correspondence between the Bishop of Exeter and Right Hon. T. B. Macaulay in January 1849 (published in 1860 ), p. 57. 
In the copy of alterations prepared by the commissioners, p. 85, in The Form and Manner of Ordering of Priests, i.e. Presbyters, against the general rubric, the following notes and additions are written on the interleaves, but without any mark to show where it was proposed to insert them.

Seeing the reformed churches abroad are in that imperfect state that they cannot receive ordination from bishops, it is humbly proposed, whether they may not be received by an imposition of a bishop's hands in these or such like words :

Take thou authority to preach the word of God and to minister the holy sacraments in this church as (q. where) thou shalt be lawfully appointed thereunto.

Whereas it has been the constant practice of the ancient church to allow of no ordinations of priests, i.e. presbyters, or deacons without a bishop, and that it has been likewise the constant practice of this church ever since the reformation to allow none that were not ordained by bishops where they could be had, yet in regard that several in this kingdom have of late years been ordained only by presbyters, the church, being desirous to do all that can be done for peace, and in order to healing of our dissensions, has thought fit to receive such as have been ordained by presbyters only to be ordained according to this office with the addition of these words in these following places.

Reverend Father etc... . order of priesthood, if they shall not [have] been already ordained.

Bishop. Good people... priesthood, if they have not been already ordained.

Receive the Holy Ghost for the office and work of a priest in the church of God... hands, if thou hast not been already ordained.

By which as she retains her opinion and practice which make a bishop necessary to the giving of orders, where he s. 
can be had, so she does likewise leave all such persons, as have been ordained by presbyters only, the freedom of their own thoughts concerning their former ordinations. It being withal expressly provided that this shall never be a precedent for the time to come, and that it shall only be granted to such as have been ordained before the day of

It is then ordered that the letters of orders in such cases should follow the form used by Archbishop Bramhall ${ }^{1}$.

This kind of action, however, was very distasteful to the majority of churchmen. Sir John Reresby records a remark of Halifax to the effect " that the churchpeople hated the Dutch, and had rather turn papists than receive the presbyterians among them ${ }^{2}$." The proposals of the commission were never even brought before convocation. They were allowed to lie undisturbed in the cupboard of Dr Tenison, afterwards Archbishop of Canterbury. A letter of Dean Comber to Bishop Patrick well expresses the general feeling of churchmen at the time. He expresses his pleasure that a man of Patrick's principles was on the commission.

'Tis true, he says, there are some few moderate presbyterians [about York], who always communicated with us on occasion, and the alterations they desire are not many nor dangerous to our constitution. They will submit to a conditional reordination.... But the greater part of dissenters here are independents, who seem incapable of any thing but toleration, and cannot be taken in but by such concessions as will shake the foundations of our church; and possibly

1 Phillpotts, ut sup. p. 59.

2 Memoirs (ed. I734), p. 343. 
by attempting to gain such as after all will be false friends we may drive out many true ones, both of the considerable clergy and laity also. I perceive the late success of that party in Scotland against episcopacy, and the opinion of their numbers and interest here, hath [given them] hopes of legal establishment and dominion over all others.

A public presbyterian ordination had recently taken place in Yorkshire. This was a new thing, and amounted to a declaration of war against the church. Comber says :

These things at this time of day, together with their giving presbyterian orders openly to many, with design to perpetuate the schism, may justly make us stand our ground till they who have neither gospel nor antiquity, neither law nor reason, of their side come some more paces toward us ${ }^{\mathbf{1}}$.

Since Comber has been mentioned, this may be an appropriate place to speak of his Companion to the Temple, first published in I672. The portion of this work consisting of $A$ Discourse upon the Form and Manner of making, ordaining, and consecrating Bishops, Priests, and Deacons according to the order of the Church of England is really a separate treatise. It was published in 1697 with a dedication to Archbishop Tenison, which assumes his concurrence in the views expressed.

Your Grace hath a right to these papers, because you are the chief governor in ordinations, under whose hands most of the Right Reverend the Bishops receive their character, with power to admit others to the inferior orders.... Our adversaries on both hands seem now to despair of their

1 Printed in Cardwell Conferences, p. 4I4. Cf. Stoughton Religion in England, vol. v. p. 284. 
baffled objections against our forms, but fail not to enlarge upon the popular theme of personal reflexions upon some defaulters.... If both clergy and people could be brought up to an adequate conformity to our incomparable rules, it would immediately be apparent...that there is nothing material to be reformed in our constitution ${ }^{1}$.

Comber's notes upon the preface to the ordinal begin by affirming that "we studiously avoid the odious charge of innovation, and therefore appeal to scripture and antiquity as our evidence that these three orders have been in the church from the apostles' time." This, he says, is a "modest" assertion, because the principle came from the Old Testament dispensation, and was adapted by our Saviour in the New. He concludes his short history of the orders with the words :

However persecution and dire necessity may perhaps excuse some late churches for being forced to mix the two first orders and to have only priests and deacons, yet we, who have a prescription of above I6oo years for us, even from the apostles' time, have the right of our side and must never depart therefrom ${ }^{2}$.

Commenting upon the words of the preface which say that men were admitted to their office by lawful authority, Comber dwells upon the nature of this authority :

which we affirm to be only bishops; and here I shall not content myself to prove this by the statute law of this land, " that no man can be a lawful priest or deacon, unless he be ordained by a bishop"," but further show this law is

1 Companion to the Temple (ed. 1702), vol. II. p. 176.

${ }^{2}$ Ibid. p. 178 .

${ }^{3}$ For this, Comber refers to 13 Eliz. cap. 12, § I, as well as to the Act of Uniformity, I4 Car. II. 


\section{The Revolution and Since}

grounded upon holy scripture, and the canons and practice of the universal church ${ }^{1}$.

\section{This he proceeds to do. His argument obliges} him to consider the reformed churches:

But some object, This will deprive divers foreign churches (where they have no bishops) of a lawful ministry, because their ministers have no ordination except by presbyters. To which I shall only say, that the first presbyter who presumed to ordain had no such power given him, and so could not rightly convey that which he never received. There is no precedent in scripture of mere presbyters ordaining alone, and such ordinations would have been declared null in the primitive ages; yea, for 1500 years together no such were allowed. But the fairest plea is that some of these churches were forced by dire necessity to this irregularity.... To which I reply, that where this necessity was real, and while it was so (as perhaps it might be in some places at first), it will go far to excuse them. But Du Plessis saith they in France might have had the assistance of some bishops who favoured the reformation, and they would not, and some of them grew so enamoured of their new way as to reordain those who were episcopally ordained; which shows it was choice in some, so that this plea cannot be urged by them. And why might not they have got some bishops privately ordained by the English or Lutherans, to keep up a legal ministry ?... So that the necessity was not unavoidable. Wherefore if any of them despise episcopal ordination, or eject them who are so ordained, as is done in Scotland, they have no excuse, and I judge their orders to be null and void.... We are thankful to that providence which allows us to keep up the primitive orders in a due subordination, and to have a right and truly canonical ministry in this well-constituted church, the exact transcript of the primitive, and the glory of the whole reformation ${ }^{2}$.

1 Companion to the Temple, vol. 1r. p. I89.

2 Ibid. p. 190. 
Beveridge, who in Birch's anecdote by implication put rubrics before charity, was a man who held to the beliefs and ideals of the age that was departing. Along with Horneck, he was the recognized leader in the revival of practical piety, especially in London.

In a series of twelve sermons he set forth the nature of the church and of its ministry. In the first of these he showed how Christ could be with his apostles to the end of the world, because the apostles continue in their successors:

The apostolical office hath been handed down from one to another ever since the apostles' days to our time, and so will be to the end of the world, Christ himself being continually present at such imposition of hands, thereby transferring the same spirit, which he had first breathed into his apostles, upon others successively after them, as really as he was present with the apostles themselves when he first breathed it into them. Insomuch that they who are thus ordained are said to be made bishops by the Holy Ghost himself, as well as the apostles were. By which means the holy catholic church always hath been, and still is, truly apostolical, as it is called in the Nicene creed. And the several parts of the apostolical office are now as effectually performed by their successors, and others ordained under them, as they were while the apostles themselves lived ${ }^{1}$.

Beveridge has already spoken earlier in the sermon of " the first and principal part of this office" as being " the ordaining others into it, and giving them power to ordain others, and so successively to the end of the world." He now calls upon his hearers

to praise, magnify, and adore the name of the most high God, in that we were born and bred, and still live, in a church

1 Works (Anglo-Cath. Library), vol. I. p. II. 
wherein the apostolical line hath through all ages been preserved entire, there having been a constant succession of such bishops in it, as were truly and properly successors to the apostles; by virtue of that apostolical imposition of hands; which being begun by the apostles hath been continued from one to another ever since their time down to ours. By which means the same spirit which was breathed by our Lord into his apostles is, together with their office, transmitted to their lawful successors, the pastors and governors of our church at this time, and acts, moves, and assists at the administration of the several parts of the apostolical office in our days as much as ever. From whence it follows that the means of grace which we now enjoy are in themselves as powerful and effectual as they were in the apostles' days. And if they prove not always so successful now as they were then, that cannot be imputed to any want of efficacy in them, but to some defect or other in those who use them ${ }^{1}$.

Again and again, in language as pious as it is lucid, Beveridge repeats this teaching of the spiritual value of the apostolic succession. He urges the duty of his hearers

to continue steadfast in the communion of our church... and not to deviate from her either into popery on the one hand or schism on the other hand.

Although the apostolical succession has been continued in the church of Rome, it has been egregiously abused, and clogged with superstitious ceremonies which quench the Spirit.

And as for schism, they certainly hazard their salvation at a strange rate who separate themselves from such a church as ours is, wherein the apostolical succession, the root of all Christian communion, hath been so entirely preserved, and

1 Works, vol. I. p. 17. 
the word and sacraments are so effectually administered; and all to go into such assemblies and meetings as can have no pretence to the great promise in my text. For it is manifest that this promise was made only to the apostles and their successors to the end of the world. Whereas in the private meetings, where their teachers have no apostolical or episcopal imposition of hands, they have no ground to pretend to succeed the apostles, nor by consequence any right to the Spirit which our Lord here promiseth ${ }^{\mathbf{1}}$.

Not that Beveridge wished to encourage a haughty attitude towards the dissenters :

But when I speak of your continuing firm and faithful to our church, I do not mean that you should only talk high for her, much less inveigh against her adversaries, or damn all those who are not of her communion ; for this is contrary to the divine and apostolical spirit that is in her, which is a spirit of meekness, and soberness, and charity. But my meaning is that you firmly believe whatsoever she, from the word of God, propounds as an article of faith, and faithfully perform whatsoever she, from the same word, requires as a necessary duty to God or man ${ }^{2}$.

In the second sermon Beveridge shows by an accurate exegesis that in the New Testament the power of ordination belongs only to the highest order in the church. After expounding 2 Tim. i. 6, he goes on to say:

Elsewhere the same apostle tells Timothy that this gift was given him by prophecy, " with the laying on of the hands of the presbytery." From whence it may seem that some of the elders of the church joined with St Paul in laying their hands upon him: and yet St Paul ascribes it wholly to the laying on of his hands, and saith the gift was given him by that, and only with the other, because he being the

1 Works, vol. I. p. 23.

${ }^{2}$ Ibid. p. 24. 


\section{The Revolution and Since}

only apostle that laid on his hands, and so the only person that had power by that means to confer the Holy Spirit, although it was given to him together with the laying on of the others' hands upon him, yet it was not given by that, but by the laying on of St Paul's hands.... How many priests soever lay their hands upon another's head, they can never make him a real priest, unless there be a bishop with them ; but a bishop by the imposition of his hands can make a priest, although there be never another priest with him ${ }^{\mathbf{1}}$.

Beveridge interprets the twenty-third article in his simple straightforward way:

In this article... we have it determined who are those who are to preach the word and administer the sacraments in the church; not every one that hath a mind to it, not every one that fancies himself fit for it : no, only such as are lawfully called thereunto... Christ called the apostles; the apostles by the appointment of the same Christ called others to succeed them, they again others; and so hath there been a succession of lawful ministers ever since, which though they were not all called immediately by Christ, yet they were all called by him; yea and all others are their successors who had this immediate call from him. So that none are now lawful ministers but such as are thus called by him, and all that are thus called by him are lawful ministers ; I mean all such as are called by such as succeed them in the ministry who were called immediately from Christ himself; for these are they which certainly we are to understand by those mentioned in this article, who have public authority given unto them in the congregation or church to call and send ministers into the Lord's vineyard ${ }^{2}$.

To this topic he returns under the thirty-sixth article :

For the proof of this I shall refer myself wholly to the judgment of the primitive church ; who, having the happiness

1 Works, vol. I. p. $39 . \quad 2$ Ibid. vol. vil. pp. 424 foll. 
to live nearer the apostles' times than we do, were better acquainted with the apostles' practice in these things than we. And for my own part I dare not but look upon the practice of the primitive church in this case to be lawful in itself and binding unto others. For if we once suppose that the primitive church generally erred in their ordination of ministers, then we must grant also that there hath never been a lawful ministry since, the lawfulness of their ministry depending principally, yea only, upon the lawfulness of their ordination; and if there were no lawful ministers to ordain them, they who were ordained could not be lawful ministers ; and if there be no lawful ministry, there cannot be any true church, because the word is not lawfully preached nor the sacraments lawfully ministered in it ${ }^{1}$.

He sees no exception to the rule of episcopal ordination :

So strict was the primitive church in having priests ordained by bishops only, that in the time of ordination, though the bishop was present and did some things, yet unless he did all he ought to do, the person was not looked upon as ordained.... If any one was convinced not to have been ordained by a bishop, he was looked upon as a layman.... It was bishops only that ordained priests, and they were no priests who were not ordained by bishops ${ }^{2}$.

There is a forcible Latin sermon of Beveridge's on I Cor. xi. I6, in which he teaches that no church can reject rites which are universal in Christendom without being guilty of schism. He turns the text against both the "pontificians" and the "sectarians"against the latter in connexion with episcopacy amongst other things :

Dicite enim, fratres dilectissimi, quo terrarum loco ecclesia unquam sine episcopo presbyteris praesidente ante

1 Works, vol. III. p. 548 .

2 Ibid. pp. 552-554. 
praesens hoc nostrum proximumque seculum constituta est ? ubi gentium ordinatio aliaque summa ecclesiae negotia a presbyterorum classe tractata sunt? quaenam est illa ecclesia ?...Cum inter omnes... constet nos nec solos nec primos esse Christianos, sed perquam plurimos omnibus retro seculis per eam quam nos profitemur religionem eandem quam nos expetimus felicitatem adeptos fuisse, quicquid hodie in religione Christiana novum est, eo nomine vel falsum vel vanum saltem et superfluum sit necesse est ${ }^{1}$.

William Cave, whose history is curiously linked with that of Beveridge, bears the testimony which was to be expected from so learned a patristic scholar. In his Primitive Christianity he feels himself absolved from discussing the question " whether episcopacy as a superior order to presbytery was of divine institution." It was enough for his immediate purpose that even Blondel and Saumaise confessed " that bishops were distinct from, and superior to, presbyters in the second century, or the next age to the apostles ${ }^{2} . "$

In $A$ Discourse concerning the Unity of the Catholic Church maintained in the Church of England, after affirming that "no church hath professed and evidenced a more awful and tender regard to antiquity next to the express word of God in the department of doctrine," he asserts, as against the Romanist, her freedom from innovation in the matter of orders :

As clear and unexceptionable hath been her proceeding in church government, preserving that form, which from all testimonies of antiquity hath continued in the church from

1 Works, vol. x. pp. $485,488$.

2 Primitive Christianity, Part I, ch. 8. 
the very apostles, under the conduct and happy influence of which Christianity hath been propagated and continued throughout the world, whatever different measures some other reformed churches have taken, whether forced by necessity, or swayed by particular inclination or prejudice. The church of England kept up the universally received distinct prime orders of bishops, priests, and deacons; not desiring to censure others, who can best answer for themselves, but endeavouring to confine herself to what was most canonical and regular, and to show how little affected she was to alteration from any establishment, except in notorious corruptions and abuses; and how necessary she thought due order and subordination in the church to prevent schisms and heresies ; and to give the greater authority and advantage to her ministrations; and finally to free herself from all suspicion of all irregularity in her succession derived down from Christ and his apostles, which she as much as any church in the world may pretend unto ${ }^{1}$.

In the same year (I659) in which Thorndike published his desponding Epilogue, and Gauden his pathetic Tears and Sighs, the young Stillingfleet, in a very different spirit, published his Irenicum. Its object was to show that no form of church government is appointed by divine right in a strict sense, and that the different systems ought to accommodate themselves to each other on the principle of give and take. There is a sense in which any form may claim the jus divinum :

Those things may be said to be jure divino which are not determined one way or another by any positive law of God, but are left wholly as things lawful, to the prudence of men to determine them in a way agreeable to natural light and the general rules of the word of God. In which sẹnse I assert

- In Gibson's Preservative against Popery (ed. 1738), vol. I. p. I40. 


\section{The Revolution and Since}

any particular form of government agreed on by the governours of the church, consonant to the general rules of scripture, to be by divine right : i.e. God by his own laws hath given men a power and liberty to determine the particular form of church government among them 1 .

Stillingfleet demands that nothing be imposed as necessary, in restraint of Christian liberty, but what is clearly revealed in the word of God; and that nothing be required or determined "but what is sufficiently known to be indifferent in its own nature." Though obedience to indifferent things be necessary when the things are commanded, yet there must be no obligation laid on consciences to consider them as necessary. When it comes to the point of determining what things are "indifferent,"

the most equal way... is to make choice of such judges as are not interested in the quarrel ; and these are the sense of the primitive church in the first four centuries, who were best able to judge whether they looked upon themselves as bound by any command of scripture or no ; and withal, the judgment of the reformed churches; so that what shall be made appear to be left indifferent by both the sense of the primitive church and the churches of the reformation may be a matter determinable by law, and which all may be required to conform in obedience to 2 .

Only, whatever is determined in this way, must be " in order to a due performance of what is in general required in the word of God, and not to be looked on as any part of divine worship or service" in such a sense as that the worship without it is deemed imperfect ; and whatever sanctions are made,

1 Works (ed. I710), vol. II. (second part), p. I6I.

${ }_{2}^{2}$ Ibid. p. 194. 
no mulcts or penalties are to be laid on those who dissent, until they have had time to consider, and even then, and even if their dissent is evidently seen to be "out of contempt," the penalties must be such as answer to the nature of the offence. Stillingfleet is sure that it is contrary to the primitive moderation to "deprive men of their ministerial function for not conforming in habits, gestures or the like." He does not at this point speak of orders ${ }^{1}$.

The law of nature dictates that there must be a way to determine all controversies which threaten to break up the unity of a society. These controversies

are either matter of different practice, or matter of different opinion. The former, if it comes from no just and necessary cause, and ends in a total separation from that society the person guilty of it was joined with, is justly called schism; which, as one defines it, is an ecclesiastical sedition, as sedition is a lay schism; both being directly contrary to that communion and friendliness which should be preserved in all societies. The latter, if impugning somewhat fundamental... or... if wilfully taken upand obstinately maintained, is called heresy... . But in order to the making clear what the church's power is in reference to these, we are to take notice ...that the church hath no direct immediate power over men's opinions.... So long as diversity of opinion tends not to the breaking the quiet and tranquillity of the church of God, a man may safely enjoy his own private apprehensions. ...It is not the difference of opinion... that is punishable, but the tendency to schism which lies in the divulging of it, and drawing away from the received truths.... The unity required in the church is not an unity of judgment and apprehension among the members of it; which though it be their duty to endeavour after, yet it is no farther attainable by man's

1 Works, vol. II. pp. 194 foll. 
endeavours than perfection is, and unio Christianorum in this sense is one of the jewels belonging to the crown of heaven ${ }^{\mathbf{1}}$.

Stillingfleet lays down the principles that " every Christian is under an obligation to join in church society with others "; that " every Christian actually joined in church society with others is so long bound to maintain society with them till his communion with them becomes sin" ; that " where any church is guilty of corruptions both in doctrine and practice, which it avoweth and professeth, and requireth the owning them as necessary conditions of communion with her, there a non-communion with that church is necessary, and a total and positive separation is lawful and convenient" ; but that "where a church retains the purity of doctrine in its public profession, but hath a mixture of some corruptions as to practice, which are only tolerated and not imposed, it is not lawful to withdraw communion from such a church, much less to run into total separation from it." $\mathrm{He}$ adds a final proposition, which he knows to be more disputable, that " where any church, retaining purity of doctrine, doth require the owning of and conforming to any unlawful or suspected practice, men may lawfully deny conformity to and communion with that church in such things, without incurring the guilt of schism."

I say not : men may proceed to positive schism, as it is called; that is, erecting of new churches, which from Cyprian is called erigere altare contra altare; but only that with-

1 Works, vol. II. pp. 220, 22 I. 
drawing communion from a church in unlawful or suspected things doth not lay men under the guilt of schism ${ }^{1}$.

Having disposed of the law of nature, Stillingfleet next enquires whether any form of government is definitely prescribed in scripture.

Matters of fact, and mere apostolical practice, may, I freely grant, receive much light from the records of succeeding ages; but they can never give a man's understanding sufficient ground to infer any divine law, arising from those facts attested to.... Supposing that apostolical practice be sufficiently attested by the following ages, yet unless it be cleared from scripture that it was God's intention that the apostles' actions should continually bind the church, there can be nothing inferred that doth concern us in point of conscience ${ }^{2}$.

He approaches the question by dismissing the independent tenet that the particular congregation is the first and only thing to be considered. Far from it :

There are other churches besides particular congregations: I mean, not only the catholic visible church, which is the first not only in order of consideration, but nature too, as a totum integrale before the similar parts of it; but in respect of all other accidental modifications of churches, from the several ways of their combination together [e.g. provincial or national churches].... It is our necessity and conveniency which makes several congregations of the catholic visible church, and not God's primary intention... that it should be understood of particular congregations.... It evidently follows that the primary notion of a church doth not belong to these, nor that these are the first subject of government, which belongs to a church as such, and not as crumbled into particular congregations ${ }^{3}$.
1 Works, vol. II. p. 228.
2 Ibid. p. $25^{\circ}$.
3 Ibid. p. $25^{2}$. 
Stillingfleet then argues that there must be a standing perpetual ministry in the church of God; and this, he says, is of divine and perpetual right, and proves it. This, then, brings him " to the main subject of the present controversy"-viz. presbyterianism versus episcopacy.

The question now is not which of these two doth come the nearest to apostolical practice and the first institution, which hath hitherto been the controversy so hotly-debated among us; but whether either of these two forms be so settled by a jus divinum... that all the churches of Christ are bound to observe that one form so determined, without variation from it.

The " most probable way" to determine is, he says, to go through " all the ways whereon men do fix an unalterable divine law" :

Either some former law standing in force under the gospel, or some plain institution of a new law by Christ in forming his church, or the obligatory nature of apostolical practice, or the general sense of the primitive church; to which we shall add, by way of appendix, the judgment of the chief divines since the reformation; if we go happily through these, we may content ourselves with 'having obtained the thing we aim at ${ }^{1}$.

With great skill and clearness Stillingfleet executes this plan. The first "way" is soon disposed of. $\mathrm{He}$ has little difficulty in showing that the general language of the apostles would be suitable on either supposition. When it comes to the fathers, he follows Mason in the main. He lays great stress on the wellknown statement of St Jerome about the presbyters

1 Works, vol. II. pt ii. p. 262.

M. 


\section{6 \\ The Revolution and Since}

of Alexandria ${ }^{1}$, and the other, to the effect that presbyters were restrained from ordaining, for fear of creating schisms ${ }^{2}$. He rather hastily assumes that these views are universally accepted.

The main controversy is, when this restraint began, and by whose act.... But in order to our peace, I see no such necessity of deciding it, both parties granting that in the church such a restraint was laid upon the liberty of ordaining presbyters : and the exercise of that power may be restrained still, granting it to be radically and intrinsecally in them. So that this controversy is not such as should divide the church. For those that are for ordinations only by a superior order in the church, acknowledging a radical power for ordination in presbyters, which may be exercised in case of necessity, do thereby make it evident that none, who grant that, do think that any positive law of God hath forbidden presbyters the power of ordination. For then it must be wholly unlawful, and so in case of necessity it cannot be valid. Which doctrine I dare with some confidence to assert to be a stranger to our church of England.... On the other side, those who hold ordinations by presbyters lawful do not therefore hold them necessary; but it being a matter of liberty, not of necessity (Christ having nowhere said that none but presbyters shall ordain), this power then may be restrained by those who have the care of the church's peace, and matters of liberty being restrained ought to be submitted to, in order to the church's peace ${ }^{3}$.

It must be borne in mind that Stillingfleet is not arguing as to what the practice of the first ages was, but as to whether there is any evidence to establish a divine law. It is, however, somewhat of a tour de force when he endeavours to prove " the uncertainty

1 Ep. Lxxxv. ad Evagrium.

${ }^{2}$ Adv. Lucif.

3 Works, vol. II. pt ii. p. 328. 


\section{The Revolution and Since}

of the primitive form of government" from "the defectiveness, ambiguity, partiality, and repugnancy," i.e. inconsistency, " of the records of the succeeding ages which should inform us what apostolical practice was," and makes fun of Eusebius's lists of bishops, " and the large diagrams made of the apostolical churches, with everyone's name set down in his order, as if the writer had been Clarencieux to the apostles themselves ${ }^{1}$." There is more ground for his contention that the apostolical succession so much pleaded by the writers of the primitive church was a succession in apostolical doctrine, rather than a succession in apostolical power ${ }^{2}$. There is still more ground for his contention that the fathers were " partial " witnesses, because they judged of the practice of the primitive church by the customs of their own ${ }^{3}$.

Stillingfleet's chapter on the views of the reformed churches and their principal divines is full of interest and research: he is the first, for instance, to print the well-known series of questions, and Cranmer's answers to them, which have since played an important part in the controversy with Rome on Anglican orders, as throwing light on the "intention " of the archbishop and his coadjutors. He groups his authorities under three heads; first, those who make the form of church government mutable, according to the wisdom and judgment of the civil power-this is the largest class; second, those who look upon " equality" as the primitive form, yet judge episcopacy lawful ; third, those who judge episcopacy to

${ }^{1}$ Works, vol. II. pt ii. p. 34I. ${ }^{2}$ Ibid. p. 345. ${ }^{3}$ Ibid. p. 353. 
be the primitive form, yet do not look upon it as necessary. As against the post-reformation dogmatists on both sides, Stillingfleet calls for robust independence.

If men would but once think their understandings at age to judge for themselves, and not make them live under a continual pupillage, and but take the pains to travel over the several churches of the reformation, they would find themselves freed of many strange misprisions they were possessed with before, and understand far better the ground and reason of their pitching upon their several forms, than they seem to do who found all things upon a divine right ${ }^{1}$.

The whole book was an astonishing performance for a man of four and twenty; and it led up with great dexterity to the point which, no doubt, the author intended all along-to ensure the acceptance of episcopacy by the very moderation with which it was demanded. Certain general principles were laid down for the approaching settlement. First, prudence must be called in. Secondly

That form of government is the best according to principles of Christian prudence, which comes the nearest to apostolical practice, and tends most to the advancing the peace and unity of the church of God. What that form is, I presume not to define and determine, but leave it to be gathered from the evidence of scripture and antiquity, as to the primitive practice, and from the nature, state, and condition of that church wherein it is to be settled, as to its tendency to the advancement of peace and unity in it.

Stillingfleet then commends the proposal of King Charles I at Newport, to " reduce episcopacy and presbytery into" a "well-proportioned form of

1 Works, vol. II. pt ii. p. 396. 
superiority and subordination,"---assumes that it will be done, i.e. that episcopacy will be restored, and adds that

all such things must be retrieved which were unquestionably of the primitive practice, but have been grown out of use through the length and corruption of times.

The restoring of presbyteries to act with the bishop, the contracting of dioceses and placing of bishops in all great towns, with other items of Usher's reduction, are among the things to be retrieved; and the arrangement so made must be submitted to ${ }^{1}$.

By the time (I68I) when he composed his treatise on the Unreasonableness of Separation, Stillingfleet had come to use the more ordinary language and arguments of the older generation. He makes an interesting observation on the statement in the preface to the ordinal that the three orders have existed from the apostles' time.

What is the reason that they express it thus, "from the apostles' time," rather than in the apostles' times, but that they believed, while the apostles lived, they managed the affairs of government themselves; but as they withdrew, they did, in some churches sooner and in some later, as their own countenance, the condition of the churches, and the qualification of persons were, commit the care and government of churches to such persons whom they appointed thereto ? Of which we have an uncontrollable evidence in the instances of Timothy and Titus.... While the apostles lived, it is probable there were no fixed bishops, or but few. But as they went off, so they came to be settled in their several churches. And as this is most agreeable to the sense of our church, so it is the fairest hypothesis for reconciling

1 Works, vol. II. pt ii. p. 4 18. 
the different testimonies of antiquity. For hereby the succession of bishops is secured from the apostles' times, for which the testimonies of Irenaeus, Tertullian, St Cyprian, and others, are so plain; hereby room is left to make good all that St Jerome hath said; and what Epiphanius delivers concerning the different settlements of churches at first. So that we may allow for the community of names between bishop and presbyter for a while in the church, i.e. while the apostles governed the churches themselves; but afterwards that which was then part of the apostolical office became the episcopal, which hath continued from that time to this by a constant succession in the church ${ }^{1}$.

\section{In 1684 Stillingfleet had concluded that}

there is as great reason to believe the apostolical succession to be of divine institution, as the canon of scripture, or the observation of the Lord's Day ${ }^{2}$.

These words occur in a sermon preached at an ordination; and in the Epistle Dedicatory to Bishop Compton prefixed to it, the preacher apologizes for his earlier utterances:

It happened, my lord, that in my younger days, about twenty-five years since, I thought it necessary to inform myself, as well as I could, in the state of the controversy about church government which had been managed with so much heat among us and was then like to be revived. And to that end I applied myself to the reading and considering the authors of greatest esteem on both sides, and by diligent perusing of them I thought them more happy in overthrowing each others' hypothesis than in setting up their own. And supposing no better reasons could be produced than I found in them, I from thence concluded that the form of church government was left at liberty by any law of Christ, and was therefore to be determined as served best to the

1 Works, vol. II. pt ii. p. 59 I.

2 Ibid. vol. I. p. 374 . 


\section{The Revolution and Since}

great ends of peace and order, which were the plain and standing laws of the Christian church.... All which, being put together, I did adventure to publish at that time, hoping by that means to bring over those to a compliance with the church of England, then like to be re-established, who stood off upon the supposition that Christ had appointed a presbyterian government to be always continued in his church... I - dare challenge any man to produce one passage in the whole book that tended to encourage faction or schism or opposition to the church of England, but on the contrary I endeavoured to recommend the episcopal government as having the advantage of all others and coming nearest to apostolical practice...

I do not deny, my lord, that I do now think much more is to be said for the apostolical institution of episcopacy than I at that time apprehended. But I confess, I yet see no cause for such clamours against the book, as though nothing could satisfy but a recantation of it "as public as the error, scandal, and offence given by it."... [My superiors in the church] were so wise, to consider the time when it was written... and with what design it was written, viz. to gain upon the dissenters from our church. And it did not want success that way, both here and in a neighbour kingdom. But suppose there were errors and mistakes in it (as no doubt there were), they were so wise to make allowance for the scepticalness and injudiciousness of youth, and for the prejudices of education. All men are not so happy to be born or bred in settled times... but suppose a man brought up when all things are in confusion, and every one at liberty to choose his own way. Was it not a fair step towards the church of England even then to receive episcopal orders, and to follow the directions of an excellent bishop of this church ? Which things I can truly affirm of myself at that time'.

1 Works, vol. I. pp. 357-359. Stillingfleet was ordained by Bishop Brownrigg, who did so much to maintain the supply of clergy during the troubles. 
The celebrated Gilbert Burnet is so commonly thought of as a latitudinarian (as in fact he was) that it is a little strange to contemplate him as a defender of the catholic episcopate in the Anglican church. He says himself :

It may seem too great a presumption in one that is a stranger in this church to engage in a question that so much concerns it. But though I had not my orders in this church, yet I derive them from it, being ordained by a bishop that had his ordination in this church ${ }^{\mathbf{1}}$; so that I am equally concerned in the issue of the question, and I am confident nobody shall have cause to imagine that I engage in it with design to betray or give it up.

Among the many unjust and spiteful calumnies with which the clergy of the Roman communion study to asperse and disgrace the reformation, there are none more frequently made use of than these; that there are no pastors lawfully called or ordained among us ; that we have not the power of making God present on our altars, as they have; nor the power of absolving from sins, much less of redeeming souls from the miseries they are under in another state. They tell their credulous followers that we were at first no better than a company of tub-preachers, and that all the disorders we saw of that sort during the late wars were as justifiable as the first beginnings of the reformation. And though the ridiculous fable of the Nag's Head be so manifest a forgery... that one might reasonably expect that all sober or discreet persons should be ashamed of so foul an imposture, yet it serves them still for many a good turn, and so they will never lay it down: though I dare boldly say, there is no matter of fact, of which there are no surviving witnesses, that can be demonstrated with clearer evidences than the regularity and canonicalness of the ordination of Archbishop Parker. Others, that are not so lost in impudence, yet say that, though we have a shadow of a succession among us,

1 He was ordained in Scotland. 
yet we show how little regard we have to orders, when we acknowledge the protestant churches beyond the seas to be true churches, though many of them do not so much as pretend to a continued succession of pastors.

For the foreign churches, they are able to speak for themselves; nor is it needful for me here to show what grounds there are for our churches holding communion with them. But it must be acknowledged to be a high pitch of boldness and injustice to charge us, as if we did not ascribe all due honour to holy orders and the succession of pastors. We know and assert that no man can take this honour of priesthood to himself, but he that is called of God, as was Aaron....We reject the extravagant and bold pretences of hotheaded or factious enthusiasts, and have learned out of the gospel that a public calling was necessary, even to those who had the most extraordinary gifts of the Holy Ghost. Our Saviour sent his disciples as his Father had sent him, and gave them the power of binding and loosing. And though God had by His spirit called Saul and Barnabas to the apostleship of the Gentiles, yet they did not enter upon the discharge of that function, till by the direction of the Holy Ghost...they were separated for the work of the ministry by prayer and imposition of hands. And though Timothy was by some prophecies marked out as a sacred person, yet he was received into that function by the imposition of St Paul's hands. From these sacred authorities, backed with the constant doctrine and practice of the churches of God in all ages, we do hold a visible vocation and ordination of pastors necessary in the church ${ }^{1}$.

These words form part of the preface to a learned and luminous work on the validity of Anglican orders, in which Burnet, making judicious use of Morinus, establishes the sufficiency of our forms, and the due authority of the persons.

1 Vindication of the Ordinations of the Church of England, printed in Gibson's Preservative against Popery, vol. I. p. 228. 
Though we have separated from many errors and corruptions of the church of Rome, and in particular have thrown out many superstitious rites out of the forms of ordination, that we might reduce these to a primitive simplicity, yet, as we acknowledge the church of Rome holds still the fundamentals of the Christian religion, so we confess she retains the essentials of ordination, which are, the separating of persons for sacred employments, and the authorising them with an imposition of hands and a prayer for the effusion of the Holy Ghost. Therefore we do not annul their orders, but receive such as come from that church, and look on them as true priests by the ordination they got among them; and such were our first reformers, from whom we have derived our ordination ${ }^{1}$.

At the close of a good and honest piece of investigation, Burnet concludes that

First, we having true priests and true bishops are a true church, since we believe all that Christ and his apostles delivered to the world.

Secondly, we being thus a part of the catholic church, every one that lives according to the doctrine professed by us may and shall be saved.

Thirdly, we do truly eat the flesh of Christ and drink his blood, having the blessed sacrament administered among us according to our Saviour's institution.

Fourthly, we have as much power to consecrate the holy sacrament as any that were ordained in the church for near a thousand years together.

Fifthly, we have the ministerial power of giving absolution and the ministry of reconciliation and of forgiving sins given us by our orders.

But, he says,

I must add that this ransacking of records about a succession of orders, though it adds much to the lustre and beauty

1 Vindication of the Ordinations of the Church of England, p. 252. 
of the church, yet it is not a thing incumbent on every body to look much into, nor indeed possible for any to be satisfied about ${ }^{1}$.

Burnet did not always, however, deal with these questions in a manner so acceptable to the church which he thus defended. His Exposition of the Thirty-nine Articles incurred the censure of the lower house of the Convocation of Canterbury ; and though the particulars with which fault was found were never disclosed, because the upper house refused to receive the paper containing them, it can hardly be doubted that some things in the exposition of Article xxIII gave offence to many.

Burnet remarks justly enough upon the latter part of the article, that it is put in very general words, " far," he says, "from that magisterial stiffness in which some have taken upon them to dictate in this matter."

They who drew it had the state of the several churches before their eyes, that had been differently reformed; and although their own had been less forced to go out of the beaten path than any other, yet they knew that all things among themselves had not gone according to those rules that ought to be sacred in regular times. Necessity has no law, and is a law to itself.

After laying it down that "lawful authority" is that rule " which the body of the pastors, or bishops and clergy of a church, shall settle, being met in a body under the due respect to the powers that God shall set over them," and that, when a church is under persecution at the hands of the civil authority, the

1 Vindication of the Ordinations of the Church of England, p. 260. 


\section{3i6 The Revolution and Since}

faithful people have a deciding voice, and in any case ought to be greatly considered, Burnet goes on :

Finally, if a company of Christians find the public worship where they live to be so defiled that they cannot with a good conscience join in it...if, I say, such a body, finding some that have been ordained, though to the lower functions ${ }^{1}$, should submit itself entirely to their conduct, or finding none of those should by a common consent desire some of their own number to minister to them in holy things, and should upon that beginning grow up to a regulated constitution, though we are very sure that this is quite out of all rule, and could not be done without a very great sin, unless the necessity were great and apparent; yet if the necessity is real and not feigned, this is not condemned or annulled by the article.... Whatever some hotter spirits have thought of this since that time, yet we are very sure that not only those who penned the articles, but the body of this church for above half an age after, did notwithstanding those irregularities acknowledge the foreign churches so constituted to be true churches as to all the essentials of a church.

It is curious that Burnet should have considered that those who penned the article had only in view the reformed churches, when he was so well aware that ministers in Roman orders were specially contemplated in all the regulations for these matters. He refers to two instances in which the work of lay evangelists in the early church led to the sending to a foreign country for duly ordained men :

These, he says, were regular practices; but if it should happen that princes or states should... apprehend that the suffering of their subjects to go elsewhere for regular ordinations might bring them under some dependence on those that had ordained them...neither our reformers nor their

$1 \mathrm{He}$ probably alludes to Calvin. 
successors for near eighty years after those articles were published did ever question the constitution of such churches.

In his comments upon Article xIx Burnet had already laid it down, that if any society retains the fundamentals of Christianity, it. is to be considered to be a true church, but that "we are not upon that bound to associate ourselves to their communion " :

Thus a plain difference is made between our owning that a church may retain the fundamentals of Christianity, a true baptism, and true orders, which are a consequent upon the former, and our joining with that church in such acts as we think are so far vitiated that they become unlawful to us to do them.

In saying this, he has an eye to the church of Rome; but it is obvious that the principle might apply in other directions also.

At the very same time that Burnet wrote his vindication of the validity of Anglican orders, another author did the same in a work of extraordinary brilliancy. This was Humphrey Prideaux; and it is a wonderful testimony to the breadth of learning to be found at that period among the English clergy, that a man whose special department of study lay in so different a quarter should be able at short notice to produce a treatise requiring the historic research and deep thought which his book displays.

His opponent argued from the insertion of certain words in the ordinal in 1662 that the church of England was conscious of something defective in her ordinations down to that date, but that it was then too late to repair the defect. Prideaux shows with 


\section{The Revolution and Since}

absolutely convincing force that the alterations were made for an entirely different purpose. They were made to meet a presbyterian, not a Roman Catholic, pretension :

In their cavils and objections in the late times against episcopacy and the superiority of the episcopal office above the priestly, they drew one argument against us from our own ordinal, such as they call argumentum ad homines, and from the very form whereby our bishops are ordained endeavoured to prove upon us that they have nothing in their office which is not also contained in the office of a priest ; the form of their ordination expressing nothing (as they urged) which doth not belong to a priest as well as a bishop even according to our own definition of the priestly office. And to take away the foundation of this argument (as I have been told) those words were put into the forms as might express a more explicit and clear distinction between the two functions. And although I do not much insist hereon (the thing not being at all material to the controversy in hand), yet I have reasons that persuade me I have not been misinformed $^{1}$. For the papist at that time was an adversary not at all thought on. The church had then just recovered itself from that many years' oppression which it had suffered from the presbyterians, and therefore had their thoughts at that time totally set how to fence themselves against the enemy that last hurt them, without having any such regard to the other adversary, at that time low enough and not at all formidable ${ }^{2}$.

In another place he says:

Do you think I am ignorant that it is the fundamental doctrine of the presbyterian sect that there is no difference at all between a bishop and a presbyter or priest ? or that

1 Prideaux's letter to Wharton, asking him to find out whether Archbishop Sancroft's recollections bore out this view, will be found in Cardwell Conferences, p. 388.

2 Ecclesiastical Tracts, by H. Prideaux (2nd ed.), p. 37. 
I could possibly say that they should urge it for a defect in our ordinal that those offices are not sufficiently distinguished therein, when it is their main principle that there is no distinction at all between them, but that they are only two names signifying the same functions?... To make a more clear distinction between the two functions, and take away all occasions for their urging of this against us for the future in the defence of that error, the explanatory words were inserted, and on no other account. When I wrote you my former paper, I confess I quoted no other authority for this but that I had been told so; but since, looking into $\mathrm{Dr}$ Burnet's History of the Reformation, I there find him saying the same thing in these words..." Having been since made use of to prove both functions the same, it was of late years altered as it is now; nor were these words being the same in giving both orders any ground to infer that the church esteemed them one order, the rest of the office showing the contrary very plainly." Thus far Dr Burnet ; and he having published it within twenty years after the thing was done, when so many were alive that were members of convocation when the alteration was made, and especially Dr Gunning and Dr Pearson, who I understand were the prime advisers of it, it is impossible he could want true information in this particular $^{1}$.

Prideaux rejects-rejects in the name of the church of England-the scholastical theory that consecration to the episcopate only " extends the character and power " already residing in the priest:

Here I must beg leave to tell you that our church holds a bishop to be as much essentially distinct from a priest as a priest is from a deacon. For that which makes the distinction of orders is the distinct powers which belong unto them. For as a priest hath a distinct power from a deacon which makes his office to be essentially distinct from

1 Ecclesiastical Tracts, p. 72. 
the office of the other, so hath a bishop also a distinct power from a priest which makes his office essentially distinct from the office of priesthood, that is, the power of ordaining, which a priest hath not; and this you must allow, or else fall in with the opinion of the presbyterians, and grant that a priest hath as much power to ordain as a bishop ${ }^{1}$.

Prideaux asserts that holy orders are not a sacrament, in the sense that there is a divinely appointed " matter" or action, which cannot be varied.

Taking the administration of holy orders thus in the true nature and notion of the thing without reckoning it a sacrament, it will appear to be no other than the delegating or transmitting from one succession to another those offices which have by divine authority been instituted in the church of Christ for the ministering of the holy things of God therein; and therefore there can remain nothing in them which may necessarily require any thing more to be done, to carry them down from one to another in a due and legal succession, than what is practised in all other offices wherein one man succeeds another; but that they may in the same manner, by a person fully authorized thereto, be validly and fully conferred by any rite and manner whatever, sufficiently declarative of the thing intended... when either by common use or public institution they have a significancy given them to denote the thing designed ${ }^{2}$.

1 Ecclesiastical Tracts, p. 46.

2 Ibid. p. 96. Prideaux does not in any way deny the spiritual gift accompanying the rite; he has just been defining the $\chi^{\alpha} \rho \iota \sigma \mu a$ as "a gift freely given to qualify and enable, in order to the performance of the office conferred." Nor does he make light of the sign of imposition of hands. "When a rite hath been so generally received in the church," he says, " and hath so venerable a stamp upon it as that of apostolic usage, the example is so enforcing as even to reach almost the very nature of a precept and oblige us to do the same thing." His argument is only directed against the Roman assertion that the tradition of the instruments is the indispensable " matter" of holy orders. Cp. p. $\mathrm{r}_{4} 8$. 
We may group together an important set of writers, now to come under review, as nonjurors. The first of this set was one of the most erudite men in that age of erudition. It was George Hickes, who was ejected from the deanery of Worcester because he could not take the oath to William and Mary.

Bishop Trimnel of Norwich, in a charge to his clergy, had expressed surprise that the presbyters of a reformed church should lay claim to " offer a proper sacrifice in the eucharist." The principle which Hickes asserts in reply is a just one, whether his application of it be accepted or not.

Surely they have a right to claim that which the prelates of the whole catholic church claimed, and to which bishops themselves were expressly ordained.... The bishop objects to little purpose that this doctrine... hath been revived of late for advancing the honour of the clergy ; but it is not any matter how lately it hath been revived, or by whom, or for what end, so it be true and catholic.... Indeed it is no argument at all... were it true that Mede and Heylin were the first publishers of it in our church, unless my lord will acknowledge it to be an argument against his own order that of all the reformed churches the church of England was the first and almost the only one which hath retained episcopacy and taught that it was to be continued in the church. How therefore, how can it be an argument against an old catholic doctrine and practice that it is at any time revived and published where it happens to be forgot, neglected, or disused $^{1}$ ?

There had been a time when Hickes was himself inclined to embrace less strict conceptions of church order than he came to hold.

1 Treatises (ed. 1847), vol. I. pp. 4, 6.

M. 
I will farther confess to you and all the world, he writes to the author of the Rights of the Christian Church asserted, that my first notions, for want of knowing better, had too much of latitude in them, and that, since I espoused the principles I now defend, the " law in my members," as the apostle calls the inclinations of flesh and blood, would have me throw them off ; but the "law of my mind," which I take to be superior, will not let me do it, but commands me to go through the strait gate, and walk in the narrow way to heaven ${ }^{1}$.

It is not always pleasant to take a strict line, and to incur from the world the reproach of narrowness and bigotry. The editor of Hickes's works, in a note on this passage, gives an extract from a letter of Hickes, which shows something of what Hickes meant. The letter was written in I707:

I freely own that when I was in France thirty-four years ago, I went to Charenton, and once there received the sacrament, and afterwards at Blois. But when I came to Montpellier, I declined the sacrament, having, by reading and conferring about the mission of the French protestant ministers, altered my opinion-I should have said my Irenicum opinion [the word is used in reference to Stillingfleet's early book], for I had no other than Irenicum principles when I went into France, having not read só much as St Ignatius' epistles, or any other father.

Perhaps no Anglican divine of that period has gone more fully into the question of communion with the reformed churches than Hickes.

The next argument he [Tindal] brings against this episcopal form of government hath been brought and answered many times. It consists in nothing but spiteful and invidious clamour against the divine right of episcopacy

1 Treatises, vol. I. p. 57. 
for " weakening the protestant cause," "for unchurching the reformed churches in other countries, particularly that in Scotland." To which I answer first that no strict doctrines are to be rejected for the severity of their consequences upon men who will not believe them, or, if they believe them, will not practise them.... Whatever hard or ugly names our men of large souls may give strict doctrines and principles, they are nevertheless true ${ }^{1}$.

In the second place...it is not the doctrine of the divine right of episcopal polity and government, or those who preach it and adhere to it as necessary by divine institution, that " weakens the protestant cause," or, as others love to speak, " widens the distance among protestants," and " unchurches the presbyterian" and other churches that are not so much as presbyterian; but as our author truly speaks, it is they themselves who "unchurch themselves" as a society by throwing off a government, and, let me add, by wilfully throwing off a government, which was instituted by God for the perpetual unalterable polity of the church. They are the men who truly weaken the protestant cause in continuing a church polity contrary to that which Christ and the apostles erected for the church in all places and ages; who take upon them the priesthood by a new uncatholic mission of their own creating; and they truly and properly widen the distance among protestants, who reject the ancient apostolical mission as needless or unlawful, and... will not move one step towards us, but expect that we should go to them and quit the ground upon which we so safely stand ${ }^{2}$.

In a long passage of great earnestness Hickes pleads with the continental protestants to restore the lost order :

I speak this with reluctance, though with freedom and plainness, I call God to witness, not to reproach the protestants of other churches who have abdicated episcopacy, buf
1 Treatises, vol. I. p. 270.
${ }^{2}$ Ibid. pp. 270 foll. 
in great charity and pity to them, beseeching them to consider if indeed they can justify themselves to Christ and the Christian world for abdicating of it and departing from the constitution and mission of the catholic church. They all, except in one place ${ }^{1}$, plead necessity for departing from it ; and I would to God their plea were good. But the necessities they plead are necessities of their own making and continuing ; chosen and wilful necessities ; and I am forced to say by consequence, unjustifiable necessities ; necessities out of which they may, and I think therefore ought to, extricate and deliver themselves as soon as they can.... Let it no longer be said of them that as they would not have bishops when they might, so now they will not have them when they may.... Let them not longer continue to give so just an offence to those who upon catholic principles and practice strictly adhere to the episcopal communion; let them not put a longer stop to the reformation by refusing to embrace the divine ordinance ${ }^{2}$.

\section{To Hickes this is no matter of compromise :}

Principles, believe me, sirs, are principles; they may easily be broken, but cannot be bent...I would have addressed myself to you with more latitude and compliance, could I have done it with a good conscience. I might indeed have told you that "the succession of the ministry is of less consideration than the succession of the faith and subordinate to it, as the means to the end." But if this may serve as some plea for those who, really using all endeavours, yet could not have episcopal mission and priesthood, yet it could serve them no longer than they were in that supposed state of... necessity, which never was nor now is your case. I might also have told you, " it was reasonable to presume that God of his infinite goodness may supply the want of his own ordinance among you." But this I could

${ }^{1}$ He means Scotland; but there were other countries of which the same might be said.

${ }^{2}$ Treatises, vol. I. pp. $2,7 \mathrm{r}$ foll. 
not do for some reasons.... The cases wherein men presume, or rather hope, that God... will make such supplies and allowances are cases of invincible ignorance or invincible necessity... neither of which, I am called to say it again, either is or ever was your case....It is not therefore reasonable, as I conceive, to presume that God, though infinitely merciful and good, will supply unto us the want of such things which we may supply ourselves with, but will not... I would for God's sake beseech you to consider how far the present constitution of your churches agrees or disagrees with your, and our, belief of the holy catholic church, or the one catholic and apostolic church, which is the corporation of all true Christians and of all true churches, founded into one communion by one priesthood, as well as upon one confession of faith ${ }^{1}$.

Hickes is deeply grieved that Tindal has constrained him to speak thus :

He would render us odious unto you for maintaining the principle upon which we have reformed, and which I think it is not in the power of man to change... . But as strict and inviolable a principle as I take it to be, yet I protest in the presence of God, so far am I from having any ill will to you, who I think live in the violation of it... that I could wish for your sakes it were not a principle; but what God hath made so for all times and places cannot be unmade ${ }^{2}$.

There is one quarter, however, to which Hickes feels none of the passionate tenderness which breathes through so many pages of appeal :

There is another protestant church which pleads not necessity to excuse their abdication of episcopacy, but declares it was their duty to cast it off as an unlawful antichristian constitution, contrary to the word of God ; and pursuant thereunto have more than once deposed their own

1 Treatises, vol. I. pp. 275 foll.

2 Ibid. p. 277. 
bishops, forced some of them by persecution to renounce their episcopal function, and entered into a solemn league and covenant, which they still think obliging, to endeavour the destruction of it. If the ancient fathers who were saints and martyrs were now living to see such a strange church, how astonished would they stand at the sight of it, and with what holy indignation would they thunder against the iniquity of it, and charge the people to separate themselves from the ministry of it, as from Corah and his company, lest they perished with them in their sin.... Notwithstanding, I trust that God, who can make dispensations and allowances for the greatest ignorances, mistakes, and prejudices of his frail creatures, which men cannot make, will show mercy in the great day, according to the prayer of our Lord upon the cross, "Father, forgive them ; they know not what they do ${ }^{1 . "}$

At this point Hickes turns aside from pursuing Tindal to engage Burnet and his Thirty-nine Articles. $\mathrm{He}$ asks pertinently whether the preface to the ordinal, the canons of 1603 , and the act of uniformity, have not given a truer key to the meaning of "lawful authority" to ordain than " his lordship's latitudeexposition ${ }^{2}$." As pertinently he asks--though he does not admit that the ministries of the foreign protestants were really owned and approved by the church of England-

if the authority of the clergy, who have questioned the lawfulness of their ordinations and missions, and utterly excluded them from ministering in our church, since the term of those eighty years mentioned by his lordship, be not as good an argument against their ministry, as the not questioning of it before that time was for it $^{3}$.

It is pleasant to find him end by quoting a more catholic passage from Burnet's own works:

1 Treatises, vol. I. p. $278 . \quad 2$ Ibid. p. $287 . \quad$ ' Ibid. p. 288. 
I will conclude, most humbly beseeching him to consider whether, instead of writing up the other protestant churches to the church of England, as one would think a bishop should do, he hath not written her down to them.... He hath observed of [episcopacy] ${ }^{1}$ that the world received the Christian religion with it ; that all the corners of the Christian church, and all the parts of it, the sound as well as the unsound, that is, the orthodox as well as the heretics and schismatics, agreed in it...." And can it be imagined," saith he, "that in all that glorious cloud of witnesses to the truth of the Christian religion...there should not be one single person found, on whom either a love to truth or envy at the advancement of others prevailed so far, as to declare against such an early and universal corruption, if it is to be esteemed one. When all this is complicated together, it is really of so great authority, that I love not to give the proper name to that temper that can withstand so plain a demonstration." This is his lordship's character of episcopacy ; and I cannot but think that a government so set up, and so universally received... deserves to be thought, not only not criminal, but necessary, as a divine institution not alterable by the will of men ${ }^{2}$.

" That detestable book," the Rights of the Christian Church, which drew forth Hickes' strictures, drew forth also from another scholar, Thomas Brett, his Account of Church Government and Governours, in 1707. He thanks God in the preface to the second edition that he has lived to see " some excellent books written in vindication of our present form of church government, and the divine institution of episcopacy in particular." Among them he names, besides Hickes' treatises, Bingham's Antiquities, and Potter's Discourse, of which last he says that to his "knowledge

1 In the preface to the Life of Bp Bedel.

2 Treatises, vol. I. pp. 29 I foll. 
it has given good satisfaction to some persons, who looked upon episcopacy before as only a prudential institution, and has convinced them of its higher origin.

Brett acknowledges that bishop and presbyter are synonyms in the New Testament ; but, he says,

it is not the name, but the thing itself, which we contend for. And that which we affirm is that the scripture in several places plainly speaks of some persons appointed by the apostles to govern the flock of Christ... whom they called presbyters or elders, and sometimes bishops, and that others were appointed to rule, govern, and superintend those elders ${ }^{1}$.

There is nothing in Brett's development of his theme which need detain us. His account of the rise of the episcopate follows the familiar lines. Perhaps the most interesting part of it is the use that he makes of some English writers who are not divines ex professo - like Bacon, Sir Henry Sidney, Sir Edward Dering -and of Cranmer's Catechism and other writings; of which he says:

I have been the more particular in this matter, that I might convince my reader that our present divines of the church of England do not at all deviate from the avowed principles of our first reformers in strenuously defending the divine unalterable rights of episcopacy, this having been the positive declared opinion of that great man and glorious martyr who was the first and chief instrument in our happy reformation ${ }^{2}$.

When he comes to the practical politics, Brett's ideas are very decided.

1 Account of Church Government (ed. I710), p. 5 I.

2 Ibid. p. 104. 
The great and most popular argument against the divine right of episcopacy is that by maintaining this doctrine we un-church all the reformed churches abroad, as well as the Scotch kyrk in the north parts of this realm, and all our own dissenters at home; and that this is one of the highest degrees of uncharitableness ${ }^{1}$.

$\mathrm{He}$ answers that it is the duty of every honest clergyman to preach the truth received from Christ, "whomsoever the consequences may reflect upon."

I can never think it charity to soothe men in their mistakes, and give them cause to think I believe them in the right when I know them to be in error. I am willing to believe as well of the protestants abroad and our dissenters at home as any man; neither will I condemn them... but as I think them to be in a dangerous error, I think it my duty to let them know it.... And I have reason to believe that if episcopacy had been settled in other reformed churches as it is in ours, the reformation had made a much larger progress than now it has done. For M. Rogne, the French ambassador, said at the time of the conference at Hampton Court, that if the other reformed churches had kept the same order amongst them that we have, he was assured there would have been many thousands of protestants more than now there are ${ }^{2}$.

For my own part I am inclined to think that there are some truths which are always seasonable: I mean such truths as are always of consequence to preserve the honour and welfare of the church of Christ. Of which nature I conceive are these following, viz., that episcopacy is of divine right ; that the college of presbyters are the bishop's council ; that to separate from our orthodox bishop is schismatical ; that schism is a damnable sin ; that if occasional conformity be lawful, constant conformity is a duty; that the church

1 Account of Church Government, p. II 4 .

2 Ibid. p. II 5. 
has a divine right to its synods or councils; that laymen ought to have no right in mere spiritual judicature, or to exercise pure ecclesiastical censures ; and such like ${ }^{\mathbf{1}}$.

Unhappily Brett, like Dodwell and some others of his time, proceeded to deny the validity of baptism when conferred by laymen, including dissenting ministers. He published two sermons (I7I2), with prefaces addressed to the dissenters, on the Honour of the Christian Priesthood, and Shewing...the utter Incapacity of our Dissenting Teachers to administer Christian Baptism. In the latter of these he says:

In the church of England therefore, the only church in this realm, which has preserved the apostolical succession of bishops, you may find persons duly authorized or commissioned to baptize.... But this succession and this commission is not to be found amongst any sect of dissenters whatsoever.... If they say they were ordained by such as had no authority to give them orders, it is the same as if they were not ordained at all... It is evident that such as are ordained by presbyters (or by those that pretend to be so) have no orders or commission at all, and all their ministerial acts are invalid. They are usurpers of the sacred office; their washing, though they call it baptism, is no baptism; their preaching is of no authority: and their pretending to administer the Lord's supper is a most abominable affront to that sacred ordinance ${ }^{2}$.

Such exaggeration, of course, tended only to discredit the truth with which it was mixed. On the accession of George I, Brett resigned his preferment, and joined the remnant of the nonjurors.

1 Account of Church Government, p. 45I. The laymen here objected to are the diocesan chancellors and other officials.

2 The Extent of Christ's Commission to baptize, pp. 22-24. 
It was in I679 that Henry Dodwell published his book bearing the title, Separation of Churches from Episcopal Government as practised by the present NonConformists proved Schismatical. The title-page goes on to say that the book explains the Sinfulness and Mischief of Schism. It was originally composed as a defence of a sermon of John Sharp, afterwards Archbishop of York, and after consultation with him.

In an interesting preface Dodwell defines the portion of the subject with which he intends to deal :

I must therefore warn my reader...that when he finds the title promise him a discourse concerning schism, he do not understand it in the same sense as it has been considered in so many modern discourses upon that subject between us and the Romanists. I do not here consider the question of schism between churches, but between subjects separating from particular churches and the churches from which they separate. This is all for which my present design does concern me, and if my reasons prove that subjects separating from their own particular churches for unsinful impositions are schismatics, I shall perform what I intended. But the same reasons will not prove a church schismatical for refusing impositions, though unsinful, from another church.

Dodwell's reason for this last statement is that all churches-he does not define what he means in the context by a church-are originally equal, and have an inalienable right to judge of conditions imposed upon them from outside.

The argument of the treatise is very elaborately built up. It starts from the need of an assured salvation. Salvation is only to be reckoned upon by using the ordinary means. The ordinary means are 
only to be had in the external communion of the visible church. They consist in the sacraments; and the validity of the sacraments depends on the authority of the persons by whom they are administered. No other ministers have the authority of administering the sacraments, but only they who receive their orders in the episcopal communion.

All ordinations, he affirms, and all administrations of the sacraments, derived from any multitudes or persons on account of their general right of governing themselves, without an express donation from God, are not only irregular but invalid, and such as can neither in conscience oblige any subjects to submit to them, nor encourage any who are otherwise willing to submit to expect any benefit from them ${ }^{1}$.

The opponents whom Dodwell had chiefly in view were the independents, who regarded their ministers as the persons deputed for the purpose by the general body of the congregation,- - the " multitude." Dodwell asks, when such an authority was bestowed upon the multitude.

So far were the apostles from giving away that power to the multitude, which they had never received from them, as that we find generally [the word "generally" at that time did not imply exceptions] the ordinations mentioned in the scriptures performed either by themselves, or by persons authorized as themselves were either by God himself or by them, not by the people ${ }^{2}$.

The apostles, not the people, took care of settling a rule for preserving succession,- - a sign that the apostles never gave the power out of their hands, at least not so far as to deprive themselves of it $^{3}$.

${ }^{1}$ Separation of Churches from Episcopal Government, etc.,' p. 425 (ed. I679).
2 Ibid. p. 436.
s Ibid. p. 447 . 
Dodwell's twenty-first chapter is occupied with the thesis that

This ecclesiastical authority cannot be derived in this age we live in from those men to whom it was at first committed, that is, from the apostles, without a continued succession of persons orderly receiving authority from those who had authority to give it them, from those first times of the apostles to ours at present ${ }^{1}$.

It contains several interesting observations. The presbyterian party contented themselves with endeavouring to prove that presbyters had the power of ordination in the earliest Christian times. Dodwell asks whether they have been careful to maintain the succession in later times.

Though our adversaries' hypothesis had been true, that single presbyters had the power of ordaining others given them when they were made presbyters, and therefore that the persons ordained by them then had been validly ordained; yet it is very possible that their succession might fail afterwards, and that later presbyters might never have that power given them, which if they have not, that is alone sufficient to disannul their present ordinations ${ }^{2}$.

He is quite prepared to believe that in some times and places presbyters were more than presbyters:

What if the apostles had left the form of government different in several places, in some episcopal, in some presbyterian, as a very learned person ${ }^{3}$ does conjecture? And what if the presbyteries of those times had indeed the power of ordination, and intended to give that power to all the particular presbyters that were ordained by them then? It does not therefore follow that the present ordinations by simple presbyters is valid also ${ }^{4}$.

${ }^{1}$ Separation of Churches, etc., p. $477 . \quad 2$ Ibid. p. 480.

${ }^{3}$ Stillingfleet in his Irenicum. ${ }_{4}^{4}$ Dodwell, ut sup. p. 482. 
In the twenty-second chapter, Dodwell argues that the authority of administering the sacraments is not now to be expected anywhere but in the episcopal communion. This, he says, is but a plain corollary from all that has gone before.

That this succession has been continued to our days in no other but the episcopal communion I conceive to be a thing so notorious as that I think our adversaries themselves will not deny it. They do not, that I know of, pretend the like uninterrupted succession in any other form of government ${ }^{1} \ldots$

I think our adversaries themselves, as many of them as pretend to a regular ordination or a valid succession, will not deny but that what orders were received by them were actually received by their forefathers in the episcopal communion, and by episcopal authority ${ }^{2}$.

He shows that certainly that authority never intended to confer upon them the power of ordaining others.

Dodwell steps aside for a few pages to consider " the opinion of the modern schools" with regard to the identity of order between bishop and priest. $\mathrm{He}$ rightly traces it to the overmastering pressure of the conceptions then current of the eucharist and of the power of consecrating it. He rightly shows that, whatever they might say, the assertors of this theory restricted the power of ordination to bishops. That being so :

If our adversaries say that the allowance of this power only to bishops will make them a distinct order, then they must confess that the authors we are speaking of were of

1 Dodwell, ut sup. p. 484.

2 Ibid. 


\section{The Revolution and Since}

our mind in the thing, and of theirs only in the use of the words, which they will find will then stand them in no stead for the present design of proving their succession. They must then say that these authors make episcopacy really a distinct order with us, though they were pleased to call it only a distinct degree with them ${ }^{1}$.

The upshot of it all is that the ordinations of the nonconformists are not only uncanonical or irregular, but actually null and void, and the nonconformist separation is in the strict sense schism,- - schism both from the particular church of this country, and from the catholic church as a whole.

Charles Leslie, like Hickes and Dodwell, was a nonjuror, and a nonjuror of the highest type. But his teaching about episcopacy was that of a sober Anglican theologian of the school of Pearson, on whose judgment he mainly relies. It was in 1698 that he printed his Discourse shewing who they are that are now qualified to administer Baptism and the Lord's Supper, wherein the cause of Episcopacy is briefly treated. It is professedly addressed to Quakers, who are supposed to have been convinced by Leslie's former arguments that they ought to receive the sacraments, but are uncertain to what quarter they ought to turn for them.

Leslie first shows that there can be no qualification but that of apostolical succession. On this principle the presbyterians and the church were at one, though they differed as to the order through which the succession was to be maintained. The presbyterians alone, " of all our dissenters, have any pretence to

1 Dodwell, ut sup. p. 502. 
succession": the later independents, baptists, and others, " have not the face to pretend to" it. Leslie affirms that the succession "is preserved and derived only in the bishops." He challenges the presbyterians "to show any one disparity between their case and that of Korah, who was a priest of the second order, that is, a presbyter, and withdrew his obedience from the high priest, with other mutinous levites." Having shown the antiquity of the episcopate, Leslie proceeds to its universality :

The whole Christian world, as it always has been, so at this present, is episcopal, except a few dissenters, who in less than two hundred years last past have arisen like a wart upon the face of the western church,--for little more proportion do our dissenters here, the Hugonots in France, the presbyterians in Holland, Geneva, and thereabouts bear to the whole body of the Latin church, which is all episcopal.... Nay more, if we should give them all those churches which own the supremacy of Rome... against those we produce the vast empire of Russia (which is greater in extent than all these popish countries before named), England, Scotland ${ }^{1}$, Denmark, Sweden, and all the Lutheran churches in Germany. ...Then we have all the rest of the Christian world wholly on the episcopal side, against both the supremacy of Rome and parity of the presbyterians; the whole Greek church, the Armenians, Georgians, Mingrelians, Jacobites, the Christians of St Thomas and St John in the east Indies, and other oriental churches; then in Africa, the Cophties in Egypt, and great empire of the Abyssins in Ethiopia. These all are episcopal ${ }^{2}$.

Leslie does not speak harshly of the foreign protestants :

1 Leslie still reckons it episcopal.

2 Discourse, etc. Section IV. 


\section{The Revolution and Since}

What allowances God will make to those who think their ordination to be good enough, and that they are true ministers of the gospel, and as such do receive the sacraments from them, I will not determine. But they have no reason to expect the like allowances who are warned of it beforehand, and will notwithstanding venture upon it, before these dissenters ${ }^{1}$ have fully and clearly acquitted themselves of so great and universal a charge laid against them ${ }^{2}$.

Nor does Leslie pretend that everything in the English church is ideal; but he calls for reasonable consideration :

Consider the grievous $\sin$ of schism and division. It is no less than the rending of Christ's body; and therefore great things ought to be borne rather than run into it,- - even all things, except only that which is apparently [i.e. evidently] sinful....And though there are some imperfections in our reformation as to discipline, and all the high places are not yet taken away (the Lord of his mercy quickly remove them), yet I will be bold to say that in our doctrine, worship, and hierarchy, nothing can be objected that is contrary to the rule of holy scripture, or anything enjoined which is there forbid to be done. And nothing less can warrant any schism against our church ${ }^{3}$.

In his Case of the Regale Leslie considers "what was the proper office of the priesthood, and for what it was ordained," with a view to knowing " how far it was to be dispensed with, and when encroachments were made upon it ${ }^{4}$." Rather scornfully he speaks of what had taken place in England in the commonwealth times:

1 Namely the foreign presbyterians.

${ }^{2}$ Discourse, etc. Section IV.

3 Ibid. Section v, § II.

4 Works, vol. I. p. 658 .

M. 
Here it was discoursed, how the notion of priesthood has been dwindled, and indeed quite taken away, in our late times of schism and rebellion, to make way for those who had no commission to show for their usurping that sacred office. Therefore they reduced it all to preaching, and loved the name of preachers better than that of priests, which they would have rejected under the gospel dispensation; and then whoever thought himself a gifted man, that is, able to speak with assurance, applied himself to the good liking of the people, and if he got a call from them, they thought this sufficient to qualify him for their teacher; and the poor people were very fond of having this authority put into their hands; as if they could choose commissioners to sign and seal the covenants of the gospel to them on the part of Christ, and oblige him, by virtue of his promise to the apostles and their successors, to ratify and confirm in heaven whatever had been transacted with them in his name by whomsoever they pleased to choose into that office, without deriving any succession from the apostles, or thinking that there was any need of it ${ }^{1}$.

The priesthood of Christ was of a prior and superior order to that of Levi, nainely that of Melchisedec :

And the same he deduced to his apostles and their successors to the end of the world; the same commission, the same glory, which his Father gave unto him. Which is now so far forgot, that men, women, and children do press into the evangelical priesthood (far superior to that of Levi) without any ordination or pretence of succession from the apostles $^{2}$.

In a vivid and instructive passage Leslie proceeds to show that the whole schism of the seventeenth century was directed, not against ceremonies and vestures, but against episcopacy. Episcopacy was

1 Works, vol. 1. p. 660.

2 Ibid. p. 666. 


\section{The Revolution and Since}

" the heir" ; of which they said, "Come, let us kill him, that the inheritance may be ours ${ }^{1}$."

John Lindsay, " a priest of the church of England," who translated Mason's Vindication, was a nonjuror likewise. To his translation is prefixed an orthodox treatise on the subject of episcopal orders. It contains not only careful lists of the English bishops from the reign of Henry VIII onwards, with the dates of their consecrations and the names of their consecrators, but a great deal of interesting and valuable history besides, especially an excellent account of the various works occasioned by the controversy.

As has been mentioned above, Lindsay vehemently rejects the assertion that Mason was the author of the Defence of the Ordinations beyond the Seas. He quotes from a learned pamphlet on the Independent power of the Church not Romish (I7I6) to prove from Thuanus that the French protestants might have had bishops for the asking, and draws the inference

that it would be absurd and inconsistent in our author, Mason, or any other orthodox divine, who asserts the divine right of episcopacy as he does, to undertake a professed vindication of the validity of their ordinations without bishops ; at least since their want of them proceeds not from necessity, but from a fixed opposition to that sacred order, and an utter aversion to all who hold it to be of divine institution ${ }^{2}$.

He quotes from the Life of Dean Barwick to show how in the days of the " detestable usurpation," when

1 Works, vol. I. p. 683.

2 Lindsay's Mason's Vindication, p. lix. 


\section{0

the church of England was " reduced again to the primitive upper rooms,"

it was judged an affair of the utmost importance "not only to the security, but possibly to the very being of the church" to provide for a succession of bishops by consecrating others into that sacred order, as had been duly taken care of by the royal martyr, notwithstanding all his own sufferings ${ }^{1}$.

A pamphlet was published in I688 by a papist, called An Agreement between the Church of England and the Church of Rome, the object of which was to make the dissenters more bitter against the church of England. The writer singled out William Sherlock, then Master of the Temple, as the dreadful example of such agreement. This called Sherlock up. He wrote $A$ Vindication of some Protestant Principles of Church Unity and Catholic Communion. Among the points which he was charged with having taught in common with Rome was this :

that what is further necessary to catholic communion is a catholic government, namely the episcopal.

Sherlock answers :

Now all these words I have used upon one occasion or other; but there is no such proposition as this in all my book. I do allow episcopacy to be an apostolical institution, and the truly ancient and catholic government of the church... but yet in this very book I prove industriously and at large that in case of necessity, when bishops cannot be had, a church may be a truly catholic church, and such as we may and ought to communicate with, without bishops, in vindication of some foreign reformed churches who have none; and therefore I do not make episcopacy so absolutely

${ }^{1}$ Lindsay's Mason's Vindication, p. lxxi. 


\section{The Revolution and Since}

necessary to catholic communion as to unchurch all churches which have it not ${ }^{1}$.

He returns to the subject in a special answer at the end of the tract.

The first agreement is about " the ministry, unto which all are required to submit, which is the same with that of Roman Catholics, and maintained by the same arguments "; that is, concerning the divine institution of bishops and subject presbyters. Now this charge we own, that we acknowledge the divine right of episcopacy, and that presbyters by the institution of their office are subject to bishops ; and if the Roman Catholics own this, we agree with them in it, and so we will in anything else that is true, and think it no injury to our cause.... And yet the mischief is that in despite of his title and design he will not suffer us to agree with them here, but endeavours to prove that we do not argue with them.

Thus he tells us:

"Touching the difference there is between a bishop and a presbyter, as amongst the papists some hold that they were of the same order, differing only in degree, and others that they were of distinct orders; so among our clergy there were some who, in King James I's days, asserted that bishops and presbyters were of the same order, but now it is carried for their being of two distinct orders." But what is this to the agreement of the two churches, that there are divines in each church which differ about this point? If neither church have determined it, then they agree only in not determining it ; but if it were the current doctrine in the council of Basil that bishops and priests are of the same order, and it be the avowed doctrine of the church of England that bishops are a distinct and superior order, then I think the two churches do not agree about this point ${ }^{2}$.

1 In Gibson's Preservative, vol. III. title ix. p. 4 Io.

2 Ibid. p. 432. 
Sherlock's adversary accentuated this disagreement. He showed that the Roman doctrine is that it is not impossible for a presbyter to be entrusted with power to ordain, but that

it is the avowed doctrine of the church of England that the giving of the power of conferring orders to a presbyter is so contrary to the divine law, that it is ipso facto null and void; and in pursuance of this doctrine, she reordains all those who have had only a presbyter's ordination, even whilst she is against a reordination.

Sherlock ridicules the argument, but his observation on the last part of it is serious :

And yet the church of England does not deny that in case of necessity the ordination of presbyters may be valid, and upon this principle justifies the presbyterian orders of foreign churches while such unavoidable necessity lasts, as I have also done in the Vindication, to which this author so often refers. But the case of schism is a different thing, and I believe our author himself, though he grants a power to the pope to entrust presbyters with the power of conferring orders, will not say that schismatical presbyters may take this power, or that their ordinations are valid, if they do. And this is the case between us and our dissenters. They ordain in a schism; and though necessity may make an irregular act valid, yet schism will not. And I would desire to know what reason it is for which they null the protestant reformed ministry: which, he says, is so much less severe than the principles of the church of England. The artifice of all this is visible enough, to heighten and inflame the difference at this time between the church of England and dissenters; but in vain is the snare laid in the sight of any bird $^{1}$.

1 In Gibson's Preservative, vol. IIt. title ix. p. 432. 
He then connects the two-order theory with the doctrine of the eucharist and the enhancing of papal authority, and says once more, with regard to the " immediate divine right" of difference between the orders :

This indeed we do constantly affirm, that the institution of episcopacy is by immediate divine right; but is this the current doctrine in the church of Rome? That he knew was false.... We wish with all our hearts, the church of Rome did agree with us in the divine institution of episcopacy, which was the sense of the primitive church; but unless all parties in the council of Trent were very much mistaken, the supremacy of the pope, as it is taught by that council, does utterly overthrow the divine institution of bishops, and makes them only the pope's creatures and dependents ${ }^{1}$.

Sherlock is included in the lists of the nonjurors, but can hardly be called a nonjuror; and from him we may turn back to men who were not troubled by scruples about the oaths.

A short tract on the Succession of Bishops, by Dr Thorp, canon of Canterbury, is incorporated in Bishop Gibson's Preservative against Popery. It deals with Bellarmine's fifth note of the church, which consists in such a succession "in Romana ecclesia ab apostolis deducta usque ad nos." Thorp enquires how far this note may be necessary to any church. He concludes :

I. That to the complete constitution of the church it will be always needful that there be in it true and lawful pastors...

1 In Gibson's Preservative, vol. III. title ix. pp. 433 foll. 
2. We yield this pastoral power originally to be from Christ, the Head of his church, the chief Bishop and Pastor of his flock, and by him immediately conveyed to the apostles, and from them derived by imposition of hands, or ordination, to their successors in the several churches which they planted, and so to be continued by a regular succession to the end of the world...

3. We grant further that according to the best evidence of scripture rule or example, and the constant practice of Christ's church, the power of ordination is intrusted with the bishops, the chief governors thereof, and ordinary successors of the apostles unto the end of the world...

All most agreeable to the doctrine and practice of the church of England. Such is our government and succession, not at all interrupted in the reformation, whatever difficulties it struggled with elsewhere. A signal happiness, for which we have reason ever to bless God, and not peevishly to endeavour by wilful and schismatical separations to deprive ourselves of that privilege, which may be the chief eyesore to our adversaries, and thereby to furnish them with new and better arguments than ever yet they found against us. If their succession be good, so is ours (for sure it is not tied to one place); whether we derive it through them by Augustine the monk, though ordained in France, or from or by the British bishops who had been here several ages before his coming, and by as regular a succession from apostolical times, without any dependence, as they profess, or as far as we can find, on the see or bishop of Rome.

\section{But Thorp will not allow that this note is every- where indispensable.}

However, it may be noted, that though this succession of bishops be necessary to the complete constitution of the church, yet it may well be doubted whether it is indispensable to the very being of it, so as to unchurch every place that wants' these....Although this obliges all Christians to endeavour to provide themselves with lawful pastors for their constant 


\section{The Rerolution and Since}

supply in all the means of grace, and so to seek them abroad, as far as they can, where they have them not at home; yet, in a supposed case, where these may not be had... they who suppose baptism to be valid, though in case of necessity administered by any Christian.... must not presently unchurch any place or exclude all persons that want this full provision of all needful helps and advantages, though some of most immediate divine institution... What allowances God may make for great necessities, or almost invincible difficulties and prejudices, where men are not wilfully and obstinately wanting to themselves, we cannot or must not determine ${ }^{1}$.

From the canon of Canterbury let us pass to his diocesan,-one of the greatest prelates who have occupied the throne of St Augustine and of Cranmer.

In his Exposition of the Doctrine of the Church of England (I686) in reply to Bossuet, Wake makes this brief comment upon Bossuet's sixteenth article, concerning the sacrament of holy orders :

The imposition of hands in holy orders, being accompanied with a blessing of the Holy Spirit, may perhaps upon that account be called a kind of particular sacrament [i.e. as distinct from a general sacrament]. Yet since that grace which is thereby conferred, whatever it be, is not common to all Christians, nor by consequence any part of that federal blessing which our blessed Saviour has purchased for us, but only a separation of him who receives it to a special employ, we think it ought not to be esteemed a common sacrament of the whole church, as baptism and the Lord's supper are.

The outward sign of it we confess to have been usually imposition of hands, and as such we ourselves observe it; yet, as we do not read that Christ himself instituted that sign, much less tied the promise of any certain grace to it,

${ }^{1}$ Gibson's Preservative, vol. r. title ii. pp. 97 foll. 


\section{The Revolution and Since}

so $\mathrm{M}$. de Meaux may please to consider that there are many of his own communion that do not think it to be essential to holy orders, nor by consequence the outward sign of a sacrament in them.

We confess that no man ought to exercise the ministerial office, till he be first consecrated to it. We believe that it is the bishop's part only to ordain. We maintain the distinction of the several orders in the church; and though we have none of these below a deacon, because we do not read that the apostles had any, yet we acknowledge the rest to have been anciently received in the church, and shall not therefore raise any controversy about them ${ }^{1}$.

Wake's friendly correspondence with the Gallican divines is well known: perhaps less attention has been paid to the correspondence which he held with the foreign protestants. Firm as his own learned catholicism was, his heart yearned towards a greater union with the reformed churches. He was conscious that they would not like to hear of his negotiations with the Sorbonne doctors, "because indeed the Gallican church will never unite with any church that has not an orderly episcopacy in it $^{2}$." Yet he did not despair, and endeavoured to keep in with both parties. He writes to Le Clerc in April I7I9, to thank him for his New Testament, of which he did not altogether approve. Yet, he says :

De rebus adiaphoris cum nemine contendendum puto. Ecclesias reformatas, etsi in aliquibus a nostra Anglicana dissentientes, libenter amplector. Optarem equidem regimen episcopale bene temperatum, et ab omni injusta dominatione sejunctum, quale apud nos obtinet, et, siquid ego in his rebus sapiam, ab ipso apostolorum aevo in ecclesia receptum fuerit

1 In Gibson's Preservative against Popery, vol. Irr. title ix. p. 32.

2 Maclaine's Mosheim (ed. r826), vol. vi. p. I79. 
[? fuit], et ab iis omnibus fuisset retentum: nec despero quin aliquando restitutum si non ipse videam, at posteri videbunt. Interim absit ut ego tam ferrei pectoris sim, ut ob ejusmodi defectum (sic mihi absque omni invidia appellare liceat) aliquas earum a communione nostra abscindendas credam; aut cum quibusdam furiosis inter nos scriptoribus eas nulla vera ac valida sacramenta habere, adeoque vix Christianos esse pronuntiem. Unionem arctiorem inter omnes reformatos procurare quovis pretio vellem. Haec si in regimine ecclesiastico ac publicis ecclesiarum officiis obtineri potuit, aut ego plurimum fallor, aut id solum brevi conduceret ad animorum inter eos unionem conciliandam, et viam sterneret ad plenam in omnibus majoris momenti dogmatibus concordiam stabiliendam. Quantum hoc ad religionis nostrae securitatem conduceret, quantum etiam ad pseudocatholicorum Romanensium conversionem, caecus sit qui non videat ${ }^{1}$.

That in the meanwhile there were limits to the intercommunion between the English church and these others is shown by an interesting letter to Archbishop Wake from his intermediary at Paris, Beauvoir, written a month later than Wake's letter to Le Clerc.

The Dutch chaplain, though he hath been assured of the contrary, persists to affirm that no reformed foreign ministry is admitted to receive ordination in the church of England, unless he own his former ordination null. This notion hath given great offence, and made a vast many of these people doubt whether we are of the same religion. And what confirms them in their opinion is that I do not allow their ministers, that preach in my Lord Stair's chapel, to make use of our liturgy, or to help me at the communion, but only to say the Lord's prayer before sermon ; and that after their sermon I conclude and give the blessing.

1 Maclaine's Mosheim, vol. vi. p. 184. The ferreum pectus is a tacit reference to Bishop Andrewes; see p. 70. 
If $\mathrm{I}$ am in the wrong, I beg pardon and farther instructions from your Grace. It would very much reconcile the minds of the protestants here to the church of England, if foreign ministers were allowed to officiate among us, and I to officiate among them. This would remove an unhappy stumbling-block, which is industriously put in our way. I can by no means believe I have authority to remove it, and therefore I earnestly entreat your Grace's commands in this particular, that I may govern myself accordingly ${ }^{\mathbf{1}}$.

There is no sign that his Grace removed the stumbling-block.

The interest felt by Wake in the cause of reunion was equally felt by his brother archbishop in the northern province. John Sharp, the spiritual adviser of Queen Anne, was a churchman belonging more strictly to the restoration type than Wake. But he was a warm friend of Tillotson's, and not illiberal in his sentiments. Like Wake, he was in favour of the Occasional Conformity bill, which aimed at preventing an unholy evasion of the Tests Act. In the debates on that occasion he is reported to have said

that if he were abroad, he would willingly communicate with the protestant churches where he should happen to be.

A French minister wished to print his words in a collection of similar utterances,

in order to show what a fraternal tenderness was... expressed... and by that means to lessen the prejudice which foreign churches may be under in relation to our opinion of them and concern for them.

Sharp refused leave. His son and biographer remarks :

${ }^{1}$ Lupton Archbishop Wake and the Project of Union, p. 97. 


\section{The Revolution and Since}

No doubt can be made but his reason for this was the ill use that would have been made of such a concession by our dissenters at home; and perhaps by some others too, who, not considering the difference there is between the case of the protestant churches abroad and our dissenting congregations here in England, might argue loosely from it that he could, in point of conscience, occasionally conform to the presbyterian way of worship in our meeting-houses ${ }^{1}$.

But Sharp was allowed to attempt something more than an act of personal communion with the foreign churches. At the beginning of the I8th century Frederick, King of Prussia, conceived a desire to unite in one communion the Lutheran communities of his kingdom and the Reformed, or Calvinists, and at the same time to introduce a settled liturgy, based on the English prayer-book. The chief agent in the cause was Jablonski (often, but wrongly, written Jablouski), the "first chaplain " of the king. Jablonski was himself a bishop,- - at that moment the sole surviving bishop,-of the Unitas Fratrum, or "Bohemian Brethren," now known as the Moravians. He had been brought up to regard the English church with horror, as a popish establishment; but on coming to England, and making acquaintance with Sancroft, Compton, and Fell, entirely changed his opinion. Jablonski entered into communications with Archbishop Sharp: Tenison, who was then (in I7II) Archbishop of Canterbury, was indisposed to take active steps in the matter. The great hope was to re-introduce a true episcopate into Germany. An extremely interesting letter from Bonnet, the Prussian

${ }^{1}$ Life of Archbishop Sharp (ed. 1825), vol. I. pp. 377, 379. 
minister at the English court, to his sovereign, gives his impressions of the way in which this rapprochement was regarded :

La première [considération est], qu'on verrait ici avec plaisir une conformité des églises prussiennes... avec celle [he is speaking of liturgical matters] de l'église anglicane. La seconde, que la conformité qu'on peut souhaiter par deça regardera moins un changement dans la liturgie et dans le rituel, que dans le gouvernement ecclésiastique; on est ici pour l'épiscopal, qu'on regarde du moins comme d'institution apostolique. La plupart du clergé est ici dans la prévention qu'il y a une succession non interrompue depuis les apôtres jusques à présent ; et suivant cette supposition ils prétendent qu'il n'y a point de bon gouvernement ecclésiastique que celui où il se rencontre des évêques de cet ordre, ni de véritables ministres de l'évangile que ceux qui ont été ordinés par des évêques. Et si d'autres ne vont pas si loin ils font toujours une grande différence entre les ministres qui ont reçu l'imposition des mains d'un évêque ou d'un synode composé des ministres ordinaires. Une troisième considération, c'est qu'une conformité de cette nature serait un triomphe pour l'église anglicane dont elle tiendrait conte; et que le clergé uni avec la cour et les Touries font un corps puissant et considérable. D'autre part les Whigs, les presbitériens... et d'autres nonconformistes ne se féliciteraient pas de cette conformité, qui les désarme, qui donne prise contre eux, qui affaiblirait leur parti. Ils la regarderaient avec chagrin, et la maison électorale de Brunswick, qui conte bien plus sur ces derniers que sur les premiers, craindrait que cette conformité n'eût d'autres conséquences ${ }^{1}$.

Unfortunately, Frederick, and Anne, and Sharp, all died within a short time of the writing of Bonnet's

1 Life of Archbishop Sharp, vol. II. pp. I75 foll. See Jablonski's own excellent comments on this letter on pp. I83 foll. 
letter. Frederick's successor had no sympathy with the project: " if he valued anything, it was an English loan, not an English liturgy 1." Nothing further came of the movement, unless in some measure it influenced Bunsen a century later in forming his scheme for the Jerusalem bishopric.

In the year 1707 , the large-minded and scholarly John Potter, afterwards Archbishop of Canterbury, published his Discourse of Church Government, as a contribution, so he says in the preface, "towards the putting a stop to those Erastian and other licentious principles, which are too rife, and have been too much countenanced by some among us."

Potter shows that the church is a society, and not " a mere voluntary society," which a believer may join or not as he thinks best, but " a society of God's appointment." Into it a man must seek admission by baptism. To say that a man may repent of his sins and keep God's commandments without being thus admitted implies a manifest contradiction, this being one of the chief commandments of God, that all men be so admitted.

Neither is it less necessary to continue in the Christian church, than it was to be first admitted into it. In mere voluntary societies men are permitted to come in and to go out again when they please. But here the command of God for our continuance in the church is as full and express as for our admission into it. The word of God must be heard, the public worship frequented, the holy sacrament of the Lord's supper received; and the Christian people are expressly commanded to obey them who have the rule over them,

' Life of Archbishop Sharp, vol. II. p. 237. 
and to submit themselves, and not to forsake the assembling of themselves together ${ }^{1}$.

This society is also an outward and visible society:

Public rulers were appointed to govern it, the faith was to be publicly confessed, the public worship of God to be frequented, and visible sacraments to be received by all the members of it ${ }^{2}$.

The public rulers here referred to were the apostles. Potter points out in an interesting way how they were gradually advanced by three stages to the plenitude of apostolic power. At their first appointment tasks were assigned to them which are now assigned to deacons. After this

they received authority to commemorate our Lord's sacrifice on the cross, when he commanded them at his last supper to do as he had done, that is, to bless the elements of bread and wine in remembrance of him: which office has constantly been performed in all ages of the church by the presbyters $^{3}$.

Then, when our Lord was going to leave the world, he again enlarged their powers. He admitted them to their office in the same manner as he was admitted to his, by the unction of the Holy Spirit. Their government was of the same nature as his. "Some have been apt to describe them rather as kings and princes of the Christian church than the ministers of Christ."

In a frank and modest manner Potter discusses the state of the ministry under the government of the apostles. His conclusion is

1 Potter's Theological Works (ed. I753), vol. II. p. I6.

2 Ibid. p. 25.

3 Ibid. p. 55. 
that in this age there were three distinct orders of ministers in the church, namely, that of deacons, another of presbyters, and over them a superior order, in which were not only the apostles, but also Timothy and Titus, who governed the churches in which they resided ${ }^{1}$.

This organization was intended to continue:

It appears both from the original state of the church, and from its nature as a society, from the divine institution of church officers, from the nature and design of their several functions, from the sense and practice of the apostles and first Christians, and lastly, from the express declaration and promise of our Lord himself, that there is to be a constant succession of officers in the church till the end of the world ${ }^{2}$.

So Potter sums up the arguments of the preceding pages, and then proceeds to show the "succession of officers of the apostolical or supreme order, from the time of the apostles down to Constantine." It would be, he says, as impossible for an impartial man to doubt this succession, as to doubt the succession of Roman emperors from Julius Caesar ${ }^{3}$.

To confirm what has been said, let us enquire whether in the age of Constantine or those next after him the government of the church by bishops was reckoned a late and human institution, or of divine appointment, and derived from the apostles. To begin with Athanasius, he tells Dracontius, who declined a bishopric to which he was elected, that, " since the government of the church by bishops was instituted by the apostles according to Christ's direction, by refusing to be a bishop in that exigence of affairs he would despise our Saviour, who ordained the episcopal office." And he adds, "that if all others before him had been of his

1 Potter's Theological Works, vol. II. p. Iro.
2 Ibid. p. 127.
3 Ibid. p. 170.

M. 
mind, he could not have been made a Christian, and if others after him should take up the same resolution, the churches could not subsist." Where he manifestly declares, that bishops were of our Lord's appointment, and essential to the constitution of the church ${ }^{\mathbf{1}}$.

Potter goes on to show that these views were universally held among the fathers. Later in the book he comes to the question of ordination :

Another power which belongs to the church is that of ordaining ministers. It has already been shown that there must always be ministers of different orders in the church, and that no man can ordinarily exercise any ecclesiastical office or function who is not lawfully called to it. It now remains to be enquired, from whom this call or commission must be expected ${ }^{2}$.

In true theological fashion, Potter goes back for " the original of this commission " to God the Father, and his mission of our Lord into the world to mediate between God and man. But this power is immediately conferred by the Holy Spirit. All ecclesiastical authority, and the graces whereby men are enabled to exercise this authority to the benefit of the church, are the gifts of the Holy Spirit.

But then it remains to be enquired, by whose ministry the Spirit is conferred for this end, or in other terms, what persons God has entrusted with authority to ordain ministers in the church. And if we may be allowed to reason from the constitution and universal practice of civil societies, we must conclude that the power of ordaining ministers belongs to the bishops, who are the chief governors of the church... . And it is against reason that they who exercise any authority,

1 Potter's Theological Works, vol. II. p. I7o.

2 Ibid. p. 257. 


\section{The Revolution and Since}

whether in the church or in the state, should derive their authority from any but those in whom the supreme authority is lodged ${ }^{1}$.

While he was on earth, our Lord reserved to himself the power of ordaining ministers. Afterwards the apostles did so.

In the same age this authority was exercised by others whom the apostles had ordained to be chief governors of churches.... In the next ages ordinations were constantly made by bishops....Even among heretics, the power of ordination was reserved to the bishops. In the next age the same practice was constantly believed to have been derived from the apostles. It was shown in the last chapter from a passage of St Chrysostom that he believed the first bishops to have been ordained by the apostles... and that the characteristical mark whereby their order is distinguished from that of presbyters is the power of ordination: consequently this prerogative was reserved to them by those persons who introduced the distinction of the two orders of bishops and presbyters into the church, that is, by our Lord and his apostles. For since the distinction of bishops and presbyters has been proved to have been of divine appointment, it necessarily follows that the power of ordination, which is the chief mark of this distinction, was reserved to the bishops by the same appointment ${ }^{2}$.

After discussing Aerius and other phenomena of the kind in early history, he sums up :

Thus it appears from the scriptures, the nature of the episcopal office, and the sense and practice of the primitive church that none but bishops have authority to ordain ministers in the church ${ }^{3}$.

1 Potter's Theological Works, vol. II. p. 259.

2 Ibid. pp. 26r-263. 3 Ibid. p. 266. 


\section{The Revolution and Since}

Potter then discusses the scriptural passages which presbyterians claimed for their side, especially the famous I Tim. iv. I4 :

But it must be remembered, he says, that the gift which is here affirmed to have been conferred on Timothy by the hands of the presbytery, in another place is said to have been given him by the putting on of St Paul's hands: so that the utmost which can be inferred from this passage is that presbyters sometimes imposed their hands together with an apostle or bishop; but there is not the least colour to conclude they always did so, or that ever they did it without a bishop ${ }^{1}$.

The last part of his treatment of ordination questions is on the point

whether the character of holy orders be perpetual and indelible, or only temporary, and like that of any civil office, which may be conferred one day and taken away the next : which is necessary to be resolved in this place, because we cannot always be certain what persons have authority to ordain, without knowing whether the episcopal character be indelible or not ${ }^{2}$.

His handling of the question is grave and firm.

Though we had no particular direction from scripture nor the practice of the primitive church, this question might easily be resolved by considering the nature of holy orders, in the susception of which two things are done. First, the persons ordained are solemnly dedicated to the service of God and his church. Consequently they cannot renounce their order without sacrilege, which has always been reckoned one of the blackest crimes.... Secondly, they who are ordained receive authority from God, in whose name the bishop puts his hands upon them; and authority conferred by God can

1 Potter's Theological Works, vol. II. p. 270.

2 Ibid. p. 273. 


\section{The Revolution and Since}

be destroyed or resumed by none but God or one commissioned by him for that purpose. Consequently... we might safely conclude...that [the character which he confers on persons admitted into orders] is perpetual, such as cannot be forfeited by any misbehaviour, nor taken away by any authority but that which gave it ${ }^{1}$.

This Potter illustrates from the analogy of baptism. But, he pursues :

Another proof that the character of orders is perpetual is that it extends over all the world. Whoever is a bishop, presbyter, or deacon, in any one church, retains the same character in all other churches, as will hereafter be proved. Now there is scarce any argument for limiting the character of order to a particular time, which does not equally hold for confining it to a certain place. For instance if the character of a bishop depended on the will of any number of people consenting to live under his ministry, as some have affirmed, then it must expire when these people are pleased to withdraw their consent, which is the foundation of this character ; and it can extend no farther than to the place where the people thus consenting inhabit. Consequently, since every bishop's character extends beyond his own diocese, in places where no number of people have consented to own him for their bishop, it is manifest that it does not depend on any such consent, and therefore will remain though the people who have once consented to own him for their bishop should afterwards change their minds ${ }^{2}$.

Potter is obliged to consider the case of bishops and others who were deposed, or went into schism. He observes that Cyprian and the Donatists rebaptized and reordained those who were baptized or ordained in schismatical assemblies ; the Luciferians, though they did not re-baptize, re-ordained.

1 Potter's Theological Works, vol. II. p. 274.

2 Ibid. p. 275. 
But this opinion and practice was not grounded upon this, that they thought priests lost their " character " when they left the church ; but that they looked on all acts done in a state of schism to be null and invalid, because not done within the church. And therefore, though they rebaptized and reordained those who had received baptism and orders in a state of schism, yet they never rebaptized or reordained those who, having been baptized or ordained in the church, turned schismatics and afterwards returned to the church. Which is a manifest proof that even these men thought the characters of baptism and orders to be indelible. However, their rebaptization and reordination of schismatics were universally condemned by the church ${ }^{1}$.

The year which gave birth to Potter's Discourse (I707), saw also the appearance of the Defensio Ecclesiae Anglicanae of William Nichols. The object of it was the same as that of Cosin's Regni Angliae Religio Catholica, to commend the Anglican position to the continental churches. In a rather high-flown dedication, Nichols addresses Queen Anne thus:

Age, princeps optima, sapientiam illam tuam, qua in rebus difficillimis maxime polles, iterum consule. Tu rationem aliquam excogita, qua in ecclesiae gremium reducantur omnes aberrantes ejus filii, quaque odia illa, quibus in nos mutuo tamdiu exacerbati fuimus, tandem ita penitus extinguantur, ut cum pontificiorum, communis nostri hostis, vim ac astutiam in fovendis nostris dissidiis eludamus, tum consentientis judicii mutuaeque benevolentiae vinculo conjuncti omnes studio aemulo id unum agamus, ut puriorem nostram fidem virtutibus Christianis quam maxime exornemus. Si hoc, princeps gloriosissima, ea qua caeteras omnes res maximas faelicitate perfeceris, tu tantum decus et honorem ecclesiae nostrae conciliabis, ut tum bene sperari potuerit, etiam exteras ecclesias reformatas non solum doctrinam (quod

' Potter's Theological Works, vol. II. p. 28I. 
nunc fere faciunt) sed disciplinam ejus et cultum amplexuras esse, aut saltem (quod earum non paucae facere inceperunt) ad ejus formam et imaginem se expressius composituras.

The thought was one which had great attractions for the churchmen of the time, and under Wake and Sharp, as we have seen, had some prospect of being realized.

The most interesting and valuable part of Nichols's book is the Apparatus prefixed to it. This is a brief but very able history of the church of England from the reformation to the writer's own time. It leads up to a project for home re-union. Repressions, comprehensions, tolerations, having failed, Nichols appeals to the foreign churches to judge between the church and the dissenters. In order that they may be enabled to do this, he sets before them in the body of the book an account of the doctrine and system of the English church. In the first part of it, he shows that the English church is free from the errors of those who were called the Remonstrants,-among which errors he reckons that of considering ordination unnecessary, and making the call of the congregation the essential part of the Christian ministry. This, he says, "nos penitus damnamus, ut scelestum quoddam in ecclesia latrocinium, et exitiabilem animarum pestem ${ }^{1}$."

The second part begins de Episcoporum Regimine. He describes the invectives of the presbyterian party against the sacred order of bishops, and makes his short profession of the Anglican view :

1 Defensio Ecclesiae Anglicanae, p. 197. 
Sed sciant obtrectatores isti eum, quem ita improbant, ordinem a Servatore ipso institutum fuisse ; ac cum apostolos Christus ante ascensionem suam Spiritu Sancto afflaverit et potestate ligandi et solvendi donaverit, tum primum episcopalem dignitatem illuxisse: apostolos ipsos in primariis civitatibus a se conversis suas cathedras tenuisse; alios deinde in apostolicum aut, quod tunc idem erat, episcopale collegium alios cooptasse : nimirum cum latius diffunderetur evangelium quam ut e cura paucorum prospiceretur. Haec partim e sacra scriptura, partim ex antiquorum patrum monimentis, tam certissime constare contendimus, ut vix ab aliquo citra modestiae dispendium possint pernegari ${ }^{1}$.

On the subject of orders, and who is to confer them, Nichols does not enlarge. He only mentions it incidentally, in the historical Apparatus. Perhaps he felt it too delicate for his immediate purpose. But in defending our cathedral establishments he says what excellent accommodation they afforded for foreign divines :

Nisi cathedralia haec suppeterent sacerdotia, non haberemus apud nos quo doctos exteros beneficio aliquo ecclesiastico augeremus. Isti enim in lingua nostra eloquenda vix unquam tam faciles sunt et expediti ut is parochiarum cura et concionatorium munus permittenda sint. Sed ad has promoti honeste vixerunt advenae plurimi, qui vel nostrae ecclesiae amore vel sui regis saevitia ad hancinsulam appulerunt. His dignitatibus insigniti apud nos rempublicam literariam ornarunt Saraviae, Casauboni, Molinaei, et qui instar omnium est, cum suae tum nostrae gentis decus, Petrus Alixius ${ }^{2}$.

In I7Io, a young fellow of Jesus College, Cambridge, John Hughes, published an edition of the de Sacerdotio of St Chrysostom. It contained several

1 Defensio Ecclesiae Anglicanae, p. 220.

2 Ibid. p. 238. 


\section{The Revolution and Since}

valuable dissertations, amongst which is one on the subject of holy orders. The author died very soon after the publication; and Hickes, who deeply deplored his loss, incorporated his dissertations in his own works. They will be found in vol. III. of Hickes's Treatises in the Anglo-Catholic Library.

With regard to the absence of direct scriptural proof for the institution of episcopacy Hughes remarks :

There is a very great difference to be made between a church to be founded, and a church which is already regularly founded and perfect in all its parts. It is foolish and absurd to expect that the scriptures should particularly enumerate all the offices in the church, when the Christian church was not yet come to full maturity. And for that reason the testimonies of the second century, when the church was now perfect and consummate, will be the safest judges in this controversy. From all this we may gather that our schismatics are guilty of the most senseless trifling, as often as they importunately demand that we should prove our three orders (viz. of bishops, priests, and deacons) from clear and express words of holy scripture. It seems abundantly sufficient for us and our cause, if we can prove (which we can very easily) that the apostles committed the care and government of cities converted to the Christian faith to single persons with a peculiar power of ordination, which could not be administered by those of the inferior orders. I assert therefore against all innovators whatsoever, that the holy scripture of the New Testament...does most clearly and fully prove that the apostles constituted bishops for the perpetual government of the catholic church, with a peculiar power of ordination.

Hughes shows in a very cogent manner that there was nothing abnormal or " extraordinary " about the 
work assigned to Timothy and Titus, but that it was just such as might be expected to continue for ever in the church. To the interesting suggestion that their appointment was a peculiarly Pauline arrangement he responds by showing how episcopacy is traced to other apostles also, especially to St John. It is objected that episcopacy, though "safe and convenient enough, and not unacceptable to God," is not thereby proved to be of perpetual obligation.

To this objection, which is plausible indeed, as well as common, I answer :

First, granting that the episcopal form of government was founded by the apostles themselves, and has been confirmed by the whole catholic church by a continual succession down to this very time, it seems from hence to be very credible that it was the intention of the apostles that this form of government should remain for ever. That the episcopal form is safe our adversaries freely own, but no man living will ever be able to prove that it is safe to alter this form. In a matter of so great importance wise men will always follow that which is certain and has been confirmed by primitive antiquity, and will most carefully avoid that which is uncertain and inconsiderate, and which may possibly prove to be against the intent of the apostolic institutions.

Secondly, the very same unquestionable evidences that prove episcopacy to have been constituted by the apostles do also prove that it was constituted with an intention of obliging perpetually. That, if I am not mistaken, is abundantly manifest from St Ignatius, St Cyprian, and the rest of the fathers, who often inculcate the necessity of episcopacy. It will be sufficient to observe that the very definition of the church given by the primitive fathers did always comprehend this form of government. St Ignatius says, "Without these" (he speaks of bishops, priests, and deacons) "it is not called a church." And St Cyprian, "They are the 


\section{The Revolution and Since}

church," says he, "the people united to the bishop, and the flock adhering to its shepherd"; and again, "That is no church which has not bishops.". .. I conclude therefore that the apostles founded episcopacy with an intention that it should oblige perpetually.

Hughes passes on to show that ordination belongs only to bishops. He does not deny that presbyters sometimes took part in the act :

I only mean that ordinations cannot be made without a bishop, and that all ordinations by presbyters, and much more by laics, are invalid and null...

We cannot allow the ordinations of presbyters; we cannot but reject them as rash, vain, and null....We are forbid to deal more mildly in a matter of so much importance by the sacred oracles, which seem to have committed this power of ordination only to the apostles and their successors. We are forbid this by the constant opinion of the catholic church, whose authority, next to that of the holy scriptures, ever has been and ever must be regarded by us as of very great weight.

All the erudition of former scholars was massed together in Joseph Bingham. His Antiquities of the Christian Church began to appear in I708. The greater part of the first volume of the edition of 1843 is occupied with questions relating to bishops. The account of the several orders of the clergy in the primitive church begins with the statement that there were three orders and no more.

Here then it remains that our inquiry be made only into the distinction betwixt the orders of bishop and presbyters. And this, so far as concerns matter of fact and the practice of the church... will be most fairly and fully resolved by considering only these three things. I. That the ancient 


\section{The Revolution and Since}

writers of the church always speak of these as distinct orders. 2. That they derive the original of bishops from divine authority and apostolical constitution. 3. That they give us particular accounts and catalogues of such bishops as were first settled and consecrated in the new-founded churches by the hands of the apostles 1 .

Bingham explains how he uses the word "order" :

I must premise one particular, to avoid all ambiguity; that I take the word " order " in that sense as the ancients use it, and not as many of the schoolmen do, who for reasons of their own distinguish between order and jurisdiction and make bishops and presbyters to be one and the same order, only differing in power and jurisdiction. This distinction was unknown to the ancients; among whom the words order, degree, office, power, and jurisdiction, when they speak of the superiority of bishops above presbyters, mean but one and the same thing, viz. the power of the supreme governors of the church, conferred upon them in their ordination, over presbyters, who are to do nothing but in subordination to them ${ }^{2}$.

He shows that bishops were always owned to be superior to presbyters, and pursues:

If we proceed a little further into this inquiry, and examine from what original this appointment came, whether from ecclesiastical or apostolical institution, which is another question concerning matter of fact that will in some measure determine the right also, the same authors, with the unanimous consent of all others, declare that it was no human invention, but an original settlement of the apostles themselves, which they made by divine appointment. "The order of bishops," says Tertullian, "when it is traced up to its original, will be found to have St John for one of its authors ${ }^{3}$."

1 Antiquities (ed. 1843), vol. I. p. 51.

2 Ibid. p. 52. He gives many examples from St Jerome.

3 Ibid. p. 56. 
An exact and authentic catalogue of these first foundations, Bingham says, " would be a very useful and entertaining thing"; but it cannot now be offered to the curiosity of the world. Yet he manages to make out a good number; which he finishes with what Theodoret says of Epaphroditus, that as Timothy and Titus were bishops of Ephesus and Crete under the name of apostles, so Epaphroditus was bishop of Philippi under the same title, which was then the common name of all that were properly bishops ${ }^{1}$.

This somewhat dubious thesis Bingham proceeds to develope on patristic authority, though he says that " afterward bishops thought it honour enough for them to be styled the apostles' successors."

I come now to consider the episcopal office and function itself : where, to do justice to antiquity, it is necessary to observe a threefold distinction between bishops and presbyters in the discharge of ecclesiastical offices. For, Ist, in the common offices,- - such as preaching, baptizing, administering the eucharist, etc., there was this obvious difference... that the one acted by an absolute and independent power, the other in dependence upon and subordination to his bishop... This is an observation not commonly made; but it is of very great use, both for establishing the just bounds of episcopal and presbyterial power, and clearing the practice of the primitive church. 2ndly, some offices were never entrusted in the hands of presbyters; nor allowed, if performed by them; such as the ordination of bishops, presbyters, etc. 3rdly, bishops always retained the power of calling their presbyters to account ${ }^{2}$.

These points are taken up in order. Upon the second, Bingham remarks that there were some offices which properly belonged to bishops, but 
which presbyters were occasionally, in cases of great necessity, commissioned to perform. He instances the reconciling of penitents, consecration of churches, even confirmation.

But there was one office, which they never entrusted in the hands of presbyters, nor ever gave them any commission to perform, which was the office of ordaining the superior clergy, bishops, presbyters, and deacons. The utmost that presbyters could pretend to in this matter was to lay on their hands together with the bishop in the ordination of a presbyter, whilst the bishop by his prayer performed the office of consecration....St Jerome's testimony is irrefragable evidence in this case; for in the same place where he sets off the office of presbyters to the best advantage, he still excepts the power of ordination....St Chrysostom speaks much after the same manner, where he advances the power of presbyters to the highest.... I know some urge the authority of St Jerome to prove that the presbyters of Alexandria ordained their own bishop from the days of St Mark to the time of Heraclas and Dionysius ; and others think the same words prove that he had no new ordination at all. But they both mistake St Jerome's meaning, who speaks not of the ordination of the bishop, but of his election, who was chosen by the presbyters out of their own body, and by them placed upon the bishop's throne; which in those days was no more than a token of his election, and was sometimes done by the people; but the ordination came after that, and was always reserved for the provincial bishops to perform ${ }^{1}$.

Bingham was drawn, like Durel in the century before him, to argue against the English nonconformists and separatists from the customs or admissions of " the French church."

1 Antiquities, vol. I. pp. 85-87. 
The principal thing in which the church of France seems to differ from the church of England is in the point of church government. They allow no pastor to have any primacy or superiority over another, but... declare them all to be of equal authority and power. But then they do not condemn other churches which have this inequality among their ministers, nor do they refuse to communicate with them, nor to submit to episcopal government in those churches where it is legally established ${ }^{1}$.

\section{He quotes Peter du Moulin the elder to this effect :}

I know that under pretence that the church of England hath another form of discipline than ours is, our adversaries (the papists) charge us that our religion is divers. But experience confuteth this accusation, for we assemble with the Englishmen in their churches, we participate together in the holy supper of our Lord ; the doctrine of their confession is wholly agreeable unto ours ${ }^{2}$.

Baxter, at any rate at this point, is the chief object of Bingham's polemic:

He says, we determine that bishops, priests, and deacons are three distinct orders, which yet is an undetermined controversy among even the most learned papists. And what follows hence? Why, that we damn and cut off men for that which the very papists leave at liberty. I must here take leave to say again that Mr Baxter was out in his argumentation. For our church does not damn or cut off all that think that bishops, priests, and deacons are not three distinct orders in the sense in which the papists take order as distinct from jurisdiction: nor do all that deny them to be three distinct orders in that sense call in question the lawfulness of our bishops, priests, or deacons, or nullify our

1 The French Church's Apology for the Church of England, in Works, vol. Ix. p. 216.

2 Ibid. p. 217. 
forms of ordination. Many French writers think bishops and priests to be the same order; and yet they do not say that our forms of ordination are repugnant to the word of God or that those are no true bishops or priests that are made by them; nor on the other hand does the church of England damn or cut them off from her communion because they believe bishops and presbyters to be the same order. Some of our best episcopal divines and true sons of the church of England have said the same, distinguishing betwixt order and jurisdiction, and made use of this doctrine to justify the ordinations of the reformed churches against the Romanists. So Mr Mason, Dr Forbes, Bishop Usher, and others, who yet defend episcopal superiority and jurisdiction as of divine appointment, at the same time that they say bishops and presbyters are but one order ${ }^{\mathbf{1}}$.

In his closing address to dissenters Bingham says :

Nor do I see what can be urged further in this case, unless it be the business of re-ordination, which some reckon so great a charge against the act of uniformity.... But what harm there is in this, I confess I never yet could see, and I am sure there is nothing in it contrary to the principles or practice of Geneva, nor perhaps of the whole French church. For I. at Geneva it is their common practice, whenever they remove a minister from one church to another, to give him a new and solemn ordination by imposition of hands and prayer. This we learn from an epistle of the pastors of Geneva to those of Berne, which is among Calvin's epistles... where, speaking of one Camperel, a minister of Geneva, who was translated to a country parish, they say, " He suffered himself to be ordained there by our brother Calvin, etc. And we do not think that to be a childish pageantry, when a minister is assigned to any church by a solemn rite with public invocation of the name of God." Now if it be lawful by the rules of the church of Geneva for a minister to receive a new solemn ordination, when he is 


\section{The Revolution and Since}

translated from one church to another, why cannot men in England consent to receive a new ordination, when the law requires it, in order to settle themselves regularly in any church? especially when it is for the sake of peace and union, and to take off all manner of doubtfulness and scruple from the people. I dispute not now whether their former ordinations were valid : it is certain they are not more valid than those of Geneva ; nor can they themselves think them more valid than the ministers of Geneva think theirs....Even supposing their former ordination to be valid, I show they may submit to a new ordination without sin: and if they will be peaceable, they ought to do it, after the example of Geneva, rather than set up separate meetings, and preach against the will of their superiors, to the disturbance of the peace of the church ${ }^{1}$.

This was lowish ground to take; but Bingham ends with an interesting appeal to the French refugees in England not to ally themselves with the dissenters, but with the English church, whose constitution and doctrine their own churches have approved :

And then, if ever it shall please God to restore them to their ancient rights and privileges, they may return triumphant without blemish or reproach, having neither denied their faith, nor deserted their principles, nor cancelled their discipline, nor opened a way by bad example for others in like manner to break in upon their establishment and destroy the union of their churches, which it has been the wisdom

1 Works, vol. Ix. p. 297. In support of the Genevan custom here mentioned, it might be alleged that in the Greek church various officers are appointed by imposition of hands and the same form of words which is pronounced at the ordination of the priesthood. Covel, Account of the present Greek Church (ed. 1722), p. 201, mentions "many of the patriarch's chief officers," "the protopresbyter, the archdeacon, the abbot or prior of a monastery, a deaconess," as all appointed this way. Probably Calvin would not have valued the support of this precedent very high. 
of national synods with so great care to maintain and preserve. They might then also return with episcopal dignity, if they pleased, more strictly united to us ; and that perhaps might make way for a more general union of all Christians ${ }^{1}$.

A writer of a very different type was Fleetwood, Bishop of St Asaph, and then of Ely. The opinion which Bingham combated, but some of the chief nonjurors championed, that lay baptism is invalid, was what drew Fleetwood to appear in print. He did so in I712, but he did so anonymously.

Although the church should not count the dissenting ministers to be duly authorized and lawful ministers, yet she need not of consequence look upon baptism administered by them as null and void from the beginning. This is begging the thing in question, and not proving it. The church may (though I do not take upon me to say she does, but supposing she may) count all the other parts of the ministration that are performed by dissenting ministers to be null and void; yet it would not necessarily follow that she should therefore count their baptisms to be null and void. ... This was held to be no consequence by the ancient church of Christ; nor is it a consequence held by the church of England ${ }^{2}$.

From 1603 to 1662 , though without ecclesiastical authority, the rubric in the prayer-book for private baptism required that the act should be performed by " the lawful minister."

Not one of them [i.e. the bishops whom King James I consulted] could think a lawful minister was intended to exclude all others from being lawful ministers but such as were episcopally ordained (that was not the doctrine of those days), nor did one of them believe that baptism conferred

1 Works, vol. Ix. pp. 301 foll.

2 Works (ed. 1737), p. 53r. 


\section{The Revolution and Since}

by an unepiscopal hand was null, invalid, and of no effect. These doctrines were reserved for the days we live in, when the divine right of episcopacy is carried to the highest pitch that words can raise it, but the bishops themselves so used as never bishops were since the days of the apostles....For this I also offer the following article to be considered.

If the church of England by inserting the words " lawful minister" meant thereby only one episcopally ordained, then she must contradict her own orders, and overthrow her own doctrine and design, by admitting and instituting and inducting into parishes such persons as had not been episcopally ordained. But this was certainly her practice during the reigns of King James and King Charles I, and to the year I66r. We had many ministers from Scotland, from France, and the Low Countries, who were ordained by presbyters only, and not bishops, and they were instituted into benefices with cure, and accordingly baptized the children of their several parishes, and did all other offices of the ministry, and yet were never reordained, but only subscribed the articles.... How will the church of England answer this? I know not how she will answer this to these new guides, and those who blindly follow them. But I believe all serious thinking people will imagine that the church of England did not by lawful ministers intend only such as were episcopally ordained, though principally such, no doubt of it. She knew and acknowledged such as were episcopally ordained to be lawful ministers in the best sense and in all the senses those words can bear, and would most heartily rejoice and give God thanks that there were no other, and would do everything fit and proper for her to do to bring that blessed work to pass. But by her practice, by her allowance, and by her institutions to parish cures of such as had not been episcopally ordained, it appears that she did not exclude them from being lawful ministers, nor consequently disannul and make void the baptisms they had conferred; which is the thing I am contending for ${ }^{1}$.

1 Works, p. 552. See below, Appendix A. 
Fleetwood treats the dissenters separately:

For the dissenters, she never thought in the least of making them Christians, but of inviting them into union and communion with the church. She exhorted and entreated them to leave the separation; and such as did so she received into her arms with gentleness and love; she received them without any renuntiation of their schism, or formal detestation of their error or offence in leaving her ; she trusted their sincerity of heart, and put them to no confusion of face. She received their children to confirmation without exception or distinction, just as she did the children of such as had been baptized in her bosom and never strayed from it. This was the temper of the bishops then [in I66I] ... I for my own part have so good an opinion of the learning, virtue, and religion of that set of bishops, that I think they must and would have declared against the validity of these antiepiscopal, unauthorised baptisms, had they believed them to be indeed null and invalid ${ }^{1}$.

He fully accepts what he considers to be the new rule:

She calls no other [baptism] lawful but that [conferred by a duly ordained minister];... but she does not therefore account all other baptism to be invalid, null, and of no effect. She takes what care she can of her own children, and would by all means keep them in the ways of regularity and order, but she does not thereby condemn all others that walk not by her rules. She will have no man accounted a priest or deacon but who is or has been ordained by bishops ; but this is in the church of England. They shall not exercise the functions of either priest or deacon; but this is in the church of England. This excludes the presbyters of France, Germany, Scotland, Holland, and of all other protestant countries, from holding any benefices, dignities, or promotions, and from exercising the functions of presbyters, in 
the church of England, unless they be or have been ordained by bishops of the Latin or Greek or of our own church. She would heretofore [i.e. even before I66I], in voto, in desire, have had no other pastors and curates but such as were episcopally ordained. She was in the right of it. That was according to the ancient rule and practice. But she did not condemn all others not so ordained, nor exclude them from exercising the functions of presbyters, even in the church of England. The case is now somewhat altered. She now excludes them all; but she does not thereby condemn them. She will have none of them baptize in England; but does she thereby disannul... the baptisms of all those countries... ? If [a presbyter from thence] desire to be a clergyman, and hold a benefice, or obtain a dignity, in the church of England, he must indeed be ordained according to the English form, or by some episcopal hand elsewhere, for that has been the law ever since I66r, and no one since that time can be accounted a lawful minister but such a one.... [The church of England] may make what laws and rules she thinks fit for those of her own communion...but she cannot pretend to invalidate the orders and the ministrations of other people, with whom she has nothing to do. Nor did she ever pretend to null any of their baptisms, which is the thing I am solely concerned about. Has not my lord of London, have not several other bishops, both heretofore and lately, ordained several protestants from abroad, and several of our own dissenting ministers at home; have they not, I say, ordained these people, without baptizing them anew ?... I have heard of people's being baptized in their blood... but I have never heard that the rites of ordination did ever confer the sacrament of baptism ${ }^{\mathbf{1}}$.

The controversy about lay-baptism involved no less a theologian than Waterland. Cautious and moderate-minded as he was, Waterland espoused the view, opposed to that of Fleetwood, that lay-baptism 


\section{4 \\ The Revolution and Since}

was null and void. At one time he had thought otherwise, but candidly and regretfully confesses his change of opinion; second thoughts, he says, robbed him of a pleasing error. His opponent, $\mathrm{Mr}$ Kelsall, urged that the ancient church accepted the validity of heretical or schismatical baptisms. Waterland's reply-he wrote in I7I3-is that

this proves nothing for lay baptism. Those heretical and schismatical baptisms were not lay baptisms; or if they were, those very churches that allowed them to be valid would have annulled them. They were administered by men of a sacerdotal character, and on that account were reputed valid. It was thought that neither schism nor heresy, nor any censures of the church, could deprive them of the indelible character; so that at any time, if they returned into the church, they were received in without being reordained.... The question in those times was not whether lay baptisms were null, both sides supposing that as an undoubted principle; but whether heresy and schism nulled orders and reduced heretical priests to mere laymen ${ }^{1}$.

The objection was raised that this doctrine would " unchurch the reformed churches abroad." Waterland refuses to be terrified by consequences, but answers :

This principle of the invalidity of lay baptism, which several of them hold as well as we, does not unchurch them, if their want of episcopal ordination doth not, which is a distinct question. If their orders are good, their baptisms are so too. If you deny them that, they will not thank you for the other ${ }^{2}$.

In further defence of this position Waterland puts forth the more dubious contention
1 Works (ed. I828), vol. x. p. 7 .
${ }^{2}$ Ibid. p. 8. 
that a man's want of valid baptism, if he is episcopally ordained, does not void his ministerial performances. A man may have orders and authority to make others what he is not himself ${ }^{1}$.

His antagonist was an able and learned man, and he had the better cause to defend. He will not let Waterland off the consequences which he wished to avoid. Lay-baptism had been allowed in the middle ages, among the people from whom our own orders and sacraments were inherited. Kelsall refuses to admit the priesthood of the unbaptized priest.

Now to suppose such baptisms are altogether null and void must needs have a terrible influence upon the state, not only of the church of England, but of all the churches of Europe. For if the baptism of such clergymen [as had been baptized by unauthorized hands] was invalid, so was their ordination.... Such men, acting as priests, could not baptize; acting as bishops, could not ordain.... The effect whereof must needs be an endless propagation of nullities in respect both of baptism and ordination. So that here is a dreadful blow given to the episcopal succession through the whole western church $^{2}$.

Kelsall could have understood this doctrine " from a Cartwright, from an enemy of our church" ; but he is corresponding with " true and zealous lovers of the church of England particularly, as well as of the catholic church in general."

If it be true, he says, (what I think we are all agreed upon) that the indefectibility of the church, promised by her Lord and Spouse, cannot otherwise subsist than with the joint subsistence of the episcopal succession, then...they who content themselves with this answer, give up...the very being of the church of England, and of the catholic church too ${ }^{3}$.

1 Works, vol. x. p. 8.

2 Ibid. p. I4.

3 Ibid. p. 15. 
He considers what Waterland had said about the reformed churches :

What they will thank us for granting, I matter not, nor does it concern the question. The church of England seems to have determined their case, allowing their baptism to be valid, their orders not. For she receives them to lay communion without rebaptization, but not into her priesthood without reordination. All my request concerning them is that (after her example), seeing by command from our ecclesiastical superiors we have often prayed for them [in the bidding prayer] by the title of the reformed churches, we would allow them as good a right to that appellation as (in the defect of other administrations) a valid Christian baptism can confer upon them. Which, though administered by lay hands, Mr L[awrence] himself seems now and then to admit in cases of extreme necessity, when not done in defiance of the episcopal divine authority ${ }^{1}$.

At the end of his long letter, Kelsall sums it up in a series of the principles on which he has gone.

I am firmly persuaded

I. That the Christian priesthood is only episcopal.

2. That it is of divine establishment.

3. Consequently unalterable by any power upon earth.

4. And shall continue to the end of the world.

5. That whosoever among us shall act as a priest, who is not consecrated by episcopal hands to that office is... a mere laic.

The rest of the principles do not concern our particular purpose.

Waterland's second letter, in reply to this, endeavours to clear the question : 


\section{The Revolution and Since}

I never knew any controversy more entangled and confused than this has been by wandering from the merits of the cause, and taking in many things which belong not to it. The question is,

Whether those that come to us from our dissenters, having been pretendedly [i.e. professedly] baptized by men that never had episcopal orders, ought to be baptized by us or no ${ }^{1}$.

Soon after, in classifying different forms of unauthorized baptisms, he gives as one such

When administered by a person not in communion, nor in case of necessity, but in contempt of authority and in schism ; being not only non-episcopal, but anti-episcopal, as in the case of pretended baptisms by our lay-dissenters, about which we are now disputing ${ }^{2}$.

By the term " our lay-dissenters " Waterland, of course, accepts the fifth principle laid down by Kelsall : he does not mean to draw a distinction between one dissenter and another ${ }^{3}$.

After examining the testimony of various fathers, Waterland, in his turn, lays down certain principles, by which the ancient church was governed. This is the fourth :

Another general principle of the ancients was that lay ordination was null and void. This need not be proved directly. It is very certain that no pretended ordination less than episcopal was ever admitted valid in the Christian church; and therefore certainly there could be no such thing as lay ordination. And does not this principle equally affect lay baptism ? Why cannot laics ordain, but because they have no commission or authority to do so 4 ?
${ }^{1}$ Works, vol. x. p. 8 o.
2 Ibid.p. 8r.

${ }^{3}$ On p. 19r he expressly says that Mr Kelsall's first five principles "are very good."

4 Works, vol. x. p. 159. 
For any company of laics to pretend to be a church, or to act independently upon their bishops, would have been thought as absurd and strange among the ancients, as if so many women only had pretended to be successors to the apostles, and to ordain, baptize, and teach, etc. Pretty remarkable are the words of St Jerome... Ecclesia autem non est, quae non habet sacerdotes ${ }^{1}$.

As for the foreign churches

allowing their baptisms and disallowing their orders seems only to be playing fast and loose, and giving in one hand to take away with the other. The church of England, [Kelsall] says, does so: if she does, I am sorry for it, and wish either to see practice changed or defended. I am sorry that what was condemned as an inconsistency in the Luciferians of old should be thought the current doctrine of our church now. As to rejecting the pretended ordinations of mere presbyters, the practice is consistent with the doctrine of our church, and conformable to our twenty-third canon ${ }^{2}$.

It is clear which way out of the " inconsistency" Waterland would have taken, whatever the consequences might be.

Among the sermons of George Smalridge, published after his death, is one Of Obedience to our Spiritual Guides and Governours. Smalridge, the friend of Atterbury, became Bishop of Bristol in I7I4. The sermon was probably preached some years earlier. Smalridge maintains that the attacks made upon episcopacy are really made in the interest of the papists :

It hath been their endeavour to depress the just rights of episcopacy, in order to advance the unjust pretences of

1 Works, vol. x. p. I6o.

2 Ibid. p. 184 . 


\section{The Revolution and Since}

papacy. All other bishops have by them been with great industry degraded, that the one bishop of Rome might be the higher extolled. When therefore we plead the cause of episcopacy against fanaticism, we do virtually plead the cause of the reformation against popery ${ }^{1}$.

Smalridge does not stand alone in this assertion, whether justified or not. His text is Heb. xiii. I7, and he says:

That we may, according to the precept here given us, pay all obedience and submission to those who have the rule over us... that we may know who those are, who according to the doctrine and institution of the apostles have the rule over us; that we may be convinced that this power of ruling doth not belong to all pastors of the church in common, but that some have, and ought to have, a superiority over the rest, I shall beg leave to trace this authority from Christ and his apostles ${ }^{2}$.

This he then does.

No one can question, but when the apostles had with God's assistance converted any number of men in any place to the Christian faith, they did there found a church ; and before they finally left it, they did furnish it with all that power which they had themselves received of Christ in order to convey it to others; and consequently did empower some persons or other to ordain successors in the ministry of the church, with whom Christ, according to his promise, might be present to the end of the world. The only question is, whether the apostles... did commit this power of governing the church and of ordaining others to one certain person in every church, or to several jointly, to wit, according to the modern way of speaking, whether to a bishop, or to a classis of presbyters ${ }^{3}$.

1 Sixty Sermons (ed. 2), p. Io3.

2 Ibid. p. I04. 3 Ibid. p. 105. 
It is unnecessary to follow Smalridge's argument, sensible and ingenious as it is, in favour of the former solution.

That before the middle of the second century, to wit, within forty years after the last of the apostles, single persons did everywhere preside over other presbyters, which single persons had the title and office of bishops...that their powers were as great as those which we claim to belong to our bishops now, is so irrefragably proved from the best and most ancient monuments of the church, that the most violent opposers of episcopal authority have been forced to confess it. And if we had no other arguments to prove the apostolical institution of episcopacy, yet to all unprejudiced persons this one concession of its adversaries is a sufficient proof of such an institution ${ }^{1}$.

The argument is admirably sustained, and leads up to the conclusion :

We are throughly persuaded, that as in the Jewish church the high priest was above the priests and levites; as in the infancy of the Christian church Christ was above the apostles and the seventy disciples; as whilst the apostles lived, they were above the other ecclesiastical officers; so, ever after their death, bishops by divine right have, and to the end of the world ought to have, authority over priests and deacons. For since the apostles in propagating and establishing the church were divinely inspired; since they did nothing but what they were taught to do by Christ; since Christ did nothing but what he was taught by the Father ; since he himself was God, and what was done by his, was done by divine authority; it comes to the same thing, whether we assert episcopacy to be of divine right or apostolical institution ${ }^{2}$. 
The preacher meets certain objections, and ends with an apology :

I am afraid that what has been said upon this subject may by some be thought too controversial, and of no great use to the direction of our practice. For several are apt to think that it is of no great moment by whom the church of Christ is governed.... But when the government of our church is by the adversaries of it accused to be disagreeable to the word of God, when such disagreement is urged as a reason against communicating with us, it is very proper for us, who think withdrawing from our communion without just cause a great sin, to show that the government of our church is so far from being a good reason to divide from it, that on the other side the want of such a government would be an objection against us which we could not well know how to answer. That there is no salvation out of an episcopal communion; that those who causelessly separate themselves from their bishops do at the same time separate themselves from Christ; that the prayers which they make, or the prayers which are made for them, whilst they are in such a state of separation, are vain and ineffectual ; that the word which they hear, and the sacraments which they receive, from persons unauthorized to preach the word and administer the sacraments, convey no benefit to them, however otherwise well disposed; are severe opinions, which, though maintained by very learned and pious men, we should out of mere pity be somewhat unwilling to make our own. For though perhaps one should not be able easily to confute them, yet such are the harsh consequences of them that I should not care to embrace them. Sufficient it is for us that in the communion of our church we are safe, whether sacraments administered by persons uncommissioned are valid, or not ${ }^{1}$.

The apostolic Bishop of Sodor and Man, Thomas 
Wilson, who was consecrated in $\mathrm{r697}$, in his Sacra Privata, gives the following

Marks of a true pastor.-I. A lawful entrance, upon motives which aim at the glory of God and the good of souls. -2. An external call from the apostolical authority of bishops ${ }^{1}$.

Of bishops he gives the following account:

A bishop is a pastor set over other pastors. They were to ordain elders. They might receive an accusation against an elder... . This was the form of church government in all ages. So that to reject this is to reject an ordinance of $\mathrm{God}^{2}$.

His life contains the account of an accusation against two elders of his diocese, through whom, no doubt, the bishop himself was attacked. Mr Ross, one of the two, was delated to him in I7I 8 by the governor, the bishop's bitter enemy, as advancing opinions savouring of popery. It came to this- " in answer to a question, I called the baptism of a popish priest valid, and that of a presbyterian minister invalid." In the written statement which he put in, Ross defended himself with vigour :

First, that the church of England allows the orders of the church of Rome to be valid, and looks upon the presbyterian ordinations invalid, and their teachers to be mere laymen. Secondly, that she utterly denies the validity of baptism by lay hands, and that the church of Rome allows and approves it. He apologizes for going into the matter at length :

Were I only to give your lordship satisfaction, the naming these things were a sufficient vindication. It would be also needless to bring arguments to prove these particulars to satisfy you, my brethren of the clergy, who are so well

1 Works (1860), vol. v. p. 59 .

${ }^{2}$ Ibid. p. 6r. 


\section{The Revolution and Since}

acquainted with the doctrine of the church, and not strangers to the controversies that are betwixt her and those that separate from her, especially papists and presbyterians, the two grand enemies of our constitution.

For the sake of others, he explains the case

If the ordinations of the church of Rome are not valid, the church of England has no orders ; we pretend to no other but what we received from them, and therefore when any of the Romish clergy come over to our church, they are obliged publicly to renounce their errors, but they receive no new orders. On the other hand, when a presbyterian or any other dissenting teacher relinquishes his schism and comes over to the church, he is never admitted to perform any ministerial act until he is ordained :-which is not to qualify him or put him in a capacity to receive a benefice, and publicly to exercise his ministry by the laws of the land, as the presbyterian teachers would have their followers believe (in this sense it would be reordination, to which the church is a stranger). No; it is because there is no ordination but what is episcopal; for it were criminal and sinful in a bishop to confer orders upon one, if he thought he already had power and commission from Christ to perform all these ministerial acts, which he in Christ's name authorizes him to perform by his imposition of hands. This were a jesting with, nay, profaning the most sacred things.

The writer was not unaware that his views were not universally held in the church of England :

And whatever the presbyterians may allege for the validity of their orders from the testimony of particular divines of our church, however high their station is in the church, it amounts to no more but a private opinion. It is not the opinion of the church of England; for she plainly tells us in one of her laws (to wit, the preface to her book of ordination) that none shall be suffered to execute any of the functions...except he hath had formerly episcopal 
consecration or ordination; and by her appealing, in this preface, to the holy scriptures and antiquity, she shows us that it is her true sense that none can execute any of the functions of the ministry but such as are episcopally ordained: so that she looks upon the dissenting teachers to be mere laymen, because they want episcopal ordination ${ }^{1}$.

Ross was acquitted. His acquittal, as Keble says, does not commit Wilson and his court to all Ross's pleadings. But Wilson at any rate thought the teaching not disloyal to the English church. Any other decision would have ejected a Waterland.

We come now to what would be a classic piece of literature, even if it were not a great religious inonument, namely William Law's Three Letters to the Bishop of Bangor. It was in I7r6, the year after his consecration, that Hoadly published his Preservative against the Principles and Practices of the Nonjurors. The great leading idea of it is that sincerity is the only thing that matters. Positive institutions of religion, definite forms of doctrine, are of little or no value. Law's first and second letters came out in I7I7, the third two years later.

The next thing that according to your lordship "we ought not to be concerned at, is vain words of regular and uninterrupted successions, as niceties, trifles, and dreams." Thus much surely is implied in these words, that no kind of ordination or mission of the clergy is of any consequence or moment to us. For if the ordination need not be regular, or derived from those who had authority from Christ to ordain, it is plain that no particular kind of ordination can be of any more value than another. For no ordination whatever can have any worse defects than as being irregular,

${ }^{1}$ Life (by Keble) prefixed to Works, pp. 379 foll. 


\section{The Revolution and Since}

and not derived by a succession from Christ. So that if these circumstances are to be looked on as trifles and dreams, all the difference that can be supposed betwixt any ordinations comes under the same notion of trifles and dreams, and consequently are either good alike or trifling alike. So that Quakers, Independents, Presbyterians, according to your lordship, have as much reason to think their teachers as useful to them and as true ministers of Christ, as those of the episcopal communion have to think their teachers ${ }^{1}$. To say this is to desert the church of England :

If episcopal ordination, derived from Christ, has been contended for by the church of England, your lordship has in this point deserted her: and you not only give up episcopal ordination by ridiculing a succession, but likewise by the same argument exclude any ministers on earth from having Christ's authority. For if there be not a succession of persons authorized from Christ to send others to act in his name, then both episcopal and presbyterian teachers are equally usurpers, and as mere laymen as any at all. For there cannot be any other difference between the clergy and laity but as the one has authority derived from Christ to perform offices, which the other has not. But this authority cannot be otherwise had than by an uninterrupted succession of men from Christ, empowered to qualify others. For if the succession be once broken, people must either go into the ministry of their own accord, or be sent by such as have no more power to send others than to go themselves ${ }^{2}$.

It is impossible for unauthorized persons to make a priest :

My lord, it is a plain and obvious truth, that no man or number of men, considered as such, can any more make a priest, or commission a person to officiate in Christ's name as such, than he can enlarge the means of grace, or add a new sacrament for the conveyance of spiritual advantages. The ministers of Christ are as much positive ordinances as

1 Westminster Library Reprint, pp. 55 foll.

2 Ibid. p. 56. M. 
the sacraments ; and we might as well think that sacraments not instituted by him might be means of grace, as those pass for his ministers who have no authority from him... . To make a jest therefore of the uninterrupted succession is to make a jest of ordination, to destroy the sacred character, and make all pretenders to it as good as those that are sent by Christ ${ }^{\mathbf{1}}$.

\section{believers : \\ This is a strange way to promote unity among}

The next thing we are not to be afraid of are "the vain words of nullity and validity of God's ordinances,"-i.e. whether they are administered by a clergyman or a layman... . Your lordship tells Dr Snape that you " know no confusion ... that you have endeavoured to introduce " into the church. My lord, if I may presume to repeat your own words, lay your hand on your heart and ask yourself whether the encouraging all manner of divisions be not endeavouring to introduce confusion. If there were in England five thousand different sects, has not your lordship persuaded them to be content with themselves, not to value what they are told by other communions; that if they are but sincere, they need not have regard to anything else? Is not this to introduce confusion? What is confusion, but difference and division? And does not your lordship plainly declare to the world that there is no need of uniting: that there is no particular way or method that can recommend us more to the favour of God than another? Has your lordship so much as given the least hint that it is better to be in the communion of the church of England than not? Have you not exposed her sacraments and clergy, and, as much as lay in you, broke down everything in her that distinguishes her from fanatical conventicles? What is there in her as a church that you have left untouched? What have you left in her that can any way invite others into her communion? Are her clergy authorized more than others? For fear that should be thought, you make a regular succession from Christ a trifle. Are her sacraments

1 Westminster Library Reprint, pp. 57 foll. 


\section{The Revolution and Since}

more regularly administered ? Lest that should recommend her, you slight the nullity or validity of God's ordinances. Is there any authority in her laws which enjoin communion with her? Lest this should be believed, you tell us that our being or continuing in any particular method or particular communion cannot recommend us more to the favour of God than another ${ }^{1}$.

The bishop had spoken of " the trifles and niceties of authoritative benedictions " and the like, and said that " to expect the grace of God from any hands but his own is to affront him." If he did not feel the sharpness of Law's reply, he was insensible indeed. Law speaks to him first, in the second letter, about the confirmations which it was his duty to administer. Then he goes on:

I come now, my lord, to another sacred and divine institution of Christ's church, which stands exposed and condemned by your lordship's doctrine; and that is the ordination of the Christian clergy; where by means of a human benediction and the imposition of the bishop's hands the Holy Ghost is supposed to be conferred on persons towards consecrating them for the work of the ministry ${ }^{2}$.

Law shows this to be the teaching of scripture, and proceeds :

And now, my lord, if human benedictions be such idle dreams and trifles; if it be affronting to God to expect his grace from them or through human hands, do we not plainly want new scriptures? Must we not give up the apostles as furious high-church prelates, who aspired to presumptuous claims, and talked of conferring the graces of God by their own hands? Was not this doctrine as strange and unaccountable then as at present? Was it not as inconsistent with the attributes and sovereignty of God at that time, to

1 Westminster Library Reprint, pp. 59 foll.

${ }^{2}$ Ibid. p. 85. 
have his graces pass through other hands than his own, as in any succeeding age? Nay, my lord, where shall we find any fathers or councils in the primitive church, but who owned and asserted these powers? They that were so ready to part with their lives rather than do the least dishonour to God or the Christian name yet were all guilty of this horrid blasphemy in imagining that they were to bless in God's name, and that by the benediction and laying on of the bishop's hands the graces of the Holy Ghost could be conferred on any persons ${ }^{1}$.

\section{Law recites the Anglican form of ordaining priests :}

From this form, he says, it is plain, firstly, that our church holds that the reception of the Holy Ghost is necessary to constitute a person a Christian priest : secondly, that the Holy Ghost is conferred through human hands : thirdly that it is by the hands of a bishop that the Holy Ghost is conferred.

If therefore your lordship is right in your doctrine, the church of England is evidently most corrupt. For if it be dishonourable and affronting to God to expect his grace from any human hands, it must of necessity be dishonourable and affronting to him for a bishop to pretend to confer it by his hands. And can that church be any ways defended that has established such an iniquity by law, and made the form of it so necessary? How can your lordship answer it to your laity, for taking the character or power of a bishop from such a form of words ? You tell them, it is affronting to God to expect his grace from human hands; yet to qualify yourself for a bishopric you let human hands be laid on you after a manner which directly supposes you thereby receive the Holy Ghost. Is it wicked in them to expect it from human hands, and is it less so in your lordship to pretend to receive it from human hands?... Certainly, he cannot be said to be very jealous of the honour of God, who will submit himself to be made a bishop by a form of words derogatory, upon his own principles, to God's honour...

1 Westminster Library Reprint, pp. 85 foll. 


\section{The Revolution and Since}

It may also well be wondered, how your lordship can accept of a character which is or ought to be chiefly distinguished by the exercise of that power which you disclaim, as in the offices of confirmation and ordination. For, my lord, where can be the sincerity of saying, " Receive the Holy Ghost by the imposition of our hands," when you declare it affronting to God to expect it from any hands but his own?... I think it is undeniably plain that you have at once, my lord, by these doctrines condemned the scriptures, the apostles, their martyred successors, the church of England, and your own conduct, and have hereby given us some reason (though I wish there were no occasion to mention it) to suspect whether you, who allow of no other church but what is founded in sincerity, are yourself really a member of any church ${ }^{\mathbf{1}}$.

All sacerdotal power, Law affirms, is derived from the Holy Ghost. Our Saviour himself received consecration from him before beginning his ministry. He conferred the Holy Ghost upon his apostles for theirs.

From this it is also manifest that the priesthood is a grace of the Holy Ghost ; that it is not a function founded in the natural or civil rights of mankind, but is derived from the special authority of the Holy Ghost, and is as truly a positive institution as the sacraments. So that they who have no authority to alter the old sacraments and substitute new ones, have no power to alter the old order of the clergy, or introduce any other order of them...

From this it likewise appears that there is an absolute necessity of a strict succession of authorized ordainers from the apostolical times in order to constitute a Christian priest. For since a commission from the Holy Ghost is necessary for the exercise of this office, no one can now receive it but from those who have derived their authority in a true succession from the apostles. We could not, my lord, call our present

1 Westminster Library Reprint, pp. 86-88. 
bibles the word of God, unless we knew the copies from which they are taken were taken from other true ones, till we come to the originals themselves. No more could we call any true ministers, or authorized by the Holy Ghost, who have not received their commission by an uninterrupted succession of lawful ordainers ${ }^{1}$.

This comparison is then further elaborated, and we read:

The clergy have their commission from the Holy Ghost ; the power of conferring this commission of the Holy Ghost was left with the apostles: therefore the present clergy cannot have the same commission or call, but from an order of men who have successively conveyed this power from the apostles to the present time. So that, my lord, I shall beg leave to lay it down as a plain, undeniable, Christian truth, that the order of the clergy is an order of as necessary obligation as the sacraments, and as unalterable as the holy scriptures; the same Holy Ghost being as truly the author and founder of the priesthood as the institutor of the sacraments or the inspirer of those divine oracles. And when your lordship shall offer any fresh arguments to prove that no particular sort of clergy is necessary; that the benedictions and administrations of the present clergy of our most excellent church are trifling niceties; if I cannot show that the same arguments will conclude against the authority of the sacraments and the scriptures, I faithfully promise your lordship to become a convert to your doctrine.

What your lordship charges upon your adversaries as an absurd doctrine, in pretending the necessity of one regular, successive, and particular order of the clergy, is a true Christian doctrine, and as certain from scripture as that we are to keep to the institution of particular sacraments, or not to alter those particular scriptures which now compose the canon of the Old and New Testament ${ }^{2}$.

1 Westminster Library Reprint, p. 102.

2 Ibid. pp. Io4 foll. 
In a scathing passage Law disposes of Hoadly's position as a champion of the layman:

Your lordship sets up in this controversy for an advocate for the laity against the arrogant pretences and false claims of the clergy. My lord, we are no more contending for ourselves in this doctrine than when we insist upon any article in the creed. Neither is it any more our particular cause when we assert our mission, than when we assert the necessity of the sacraments. Who is to receive the benefit of that commission which we assert, but they? Who is to suffer if we pretend a false one, but ourselves? Sad injury indeed offered to the laity! That we should affect to be thought ministers of God for their sakes! If we really are so, they are to receive the benefit ; if not, we are to bear the punishment.

But your lordship comes too late in this glorious undertaking, to receive the reputation of it; the work has been already, in the opinion of most people, better done to your lordship's hands. The famous author of the Rights of the Christian Church ${ }^{1}$ has carried this Christian liberty to as great heights as your lordship. And though you have not one notion I can recollect, that has given offence to the world, but what seems taken from that pernicious book, yet your lordship is not so just as ever once to cite or mention the author; who, if your lordship's doctrine be true, deserves to have a statue erected to his honour, and receive every mark of esteem which is due to the greatest reformer of religion ${ }^{2} \ldots$

Suppose, my lord, some laymen upon a pretence of your lordship's absence or any other ${ }^{3}$ should go into the diocese of Bangor, and there pretend to ordain clergymen, could your lordship quote one text of scripture against him ? Could you allege any law of Christ or his apostles that he had broken? Could you prove him guilty of any sin? No,

1 Tindal.

2 Westminster Library Reprint, p. I07.

3 Hoadly scarcely set foot in the diocese of Bangor. 
my lord, you would not do that, because this would be acknowledging such a thing as a sinful ordination; and if there be sinful ordinations, then there must be some law concerning ordinations; for sin is the transgression of the law; and if there be a law concerning ordinations, then we must keep to the clergy lawfully ordained, and must confess, after all your lordship has said, or can say, that still some communions are safer than others ${ }^{1}$.

In a postscript to this letter Law goes further into the doctrine of the uninterrupted succession of the clergy.

I have, as I think, proved that there is a divine commission required to qualify anyone to exercise the priestly office, and that seeing this divine commission can only be had from such particular persons as God has appointed to give it, therefore it is necessary that there should be a continual succession of such persons, in order to keep up a commissioned order of the clergy. For if the commission itself be to descend through ages, and distinguish the clergy from the laity, it is certain the persons who alone can give this commission must descend through the same ages; and consequently an uninterrupted succession is as necessary as that the clergy have a divine commission. Take away this succession, and the clergy may as well be ordained by one person as another; a number of women may as well give them a divine commission as a congregation of any men. They may indeed appoint persons to officiate in holy orders for the sake of decency and order, but then there is no more in it than an external decency and order; they are no more the priests of God than those that pretended to make them so $^{2}$.

Hoadly said that there was no mention in scripture of an uninterrupted succession of clergy as having any relation to the being of a church. Law replies

1 Westminster Library Reprint, p. I Io.

2 Ibid. p. I49. 
that there are other true things which are not expressly mentioned in scripture-for instance that the sacraments were to be used for all time :

If it be a good argument against the necessity of episcopal ordainers that it is never said in scripture that there shall always be such ordainers, it is certainly as conclusive against the use of the sacraments in every age, that it is nowhere said in scripture they shall be used in all ages. If no government or order of the clergy be to be held as necessary, because no such necessity is asserted in scripture, it is certain this concludes as strongly against government and the order itself, as against any particular order. For it is no more said in scripture that there shall be an order of clergy than that there shall be any particular order... . Should therefore any of your lordship's friends have so much church zeal as to contend for the necessity of some order, though of no particular order, he must fall under your lordship's displeasure, and be proved as mere a dreamer and trifler as those who assert the necessity of episcopal ordination ${ }^{1}$...

For, my lord, though it be not expressly said that there shall always be a succession of episcopal clergy, yet it is a truth founded in scripture itself, and asserted by the universal voice of tradition in the first and succeeding ages of the church.... Thus Timothy was sent to ordain elders, because none below his order, who was a bishop, could perform that office.... And do not the same scriptures make it as necessary that Timothy's successor be the only ordainer, as well as he was in his time? Will not priests in the next age be as destitute of the power of ordaining as when Timothy was alive? So that since the scriptures teach that Timothy, or persons of his order, could alone ordain in that age, they as plainly teach that the successors of that order can alone ordain in any age, and consequently the scriptures plainly teach a necessity of an episcopal succession ${ }^{2}$.

1 Westminster Library Reprint, p. ${ }_{52}$.

2 Ibid. pp. 153-I 55. 


\section{The Revolution and Since}

The great objection, Law says, is " that this episcopal order of the clergy is only an apostolical practice," and that apostolical practice is not always binding. He replies :

It is not true that the divine unalterable right of episcopacy is founded merely upon apostolical practice. We do not say that episcopacy cannot be changed merely because we have apostolical practice for it, but because such is the nature of the Christian priesthood that it can only be continued in that method which God has appointed for its continuance... The apostolical practice indeed shows that episcopacy is the order that is appointed, but it is the nature of the priesthood that assures us that it is the unalterable.... The argument proceeds thus: The Christian priesthood is a divine positive institution, which as it could only begin by the divine appointment, so it can only descend to after ages in such a method as God has been pleased to appoint. The apostles... instituted episcopacy alone; therefore this method of episcopacy is unalterable, not because an apostolical practice cannot be laid aside, but because the priesthood can only descend to after ages in such a method as is of divine appointment ${ }^{1}$.

Hoadly poured scorn upon the doctrine, because there was so much uncertainty about the maintenance of the succession that "we can never say that we are in the church." Law answers that there is sufficient historical evidence to satisfy us :

And though your lordship has told the world so much of the improbability, nonsense, and absurdity of this succession, yet I promise your lordship an answer, whenever you shall think fit to show when, or how, or where this succession broke, or seemed to break, or was likely to break ${ }^{2}$.

1 Westminster Library Reprint, pp. 159 foll.

2 Ibid. p. I62. 


\section{The Revolution and Since}

The doctrine itself is sufficient guarantee for the fact :

I shall content myself with offering this reason to your lordship, why it is morally impossible it ever should have broken in all that term of years from the apostles to the present times. The reason is this : it has been a received doctrine in every age of the church, that no ordination was valid but that of bishops. This doctrine, my lord, has been a constant guard upon the episcopal succession ; for seeing it was universally believed that bishops alone could ordain, it was morally impossible that any persons could be received as bishops, who had not been so ordained.

Now is it not morally impossible that in our church any one should be made a bishop without episcopal ordination? Is there any possibility of forging [episcopal] orders, or stealing a bishopric by any other stratagem ? No, it is morally impossible, because it is an acknowledged doctrine amongst us that a bishop can only be ordained by bishops. Now as this doctrine must necessarily prevent any one being a bishop without episcopal ordination in our age, so it must have the same effect in every other age as well as ours ; and consequently it is as reasonable to believe that the succession of bishops was not broken in any age since the apostles, as that it was not broken in our own kingdom within these forty years ${ }^{1}$.

Opinions may differ with regard to the force of some of Law's arguments; but there can be no question that the belief which he sought to uphold by them was the belief of the church of England, and that he, not Hoadly, was the true representative of Anglican conviction.

Two general treatises on Christian divinity published about the same time may be mentioned here.

1 Westminster Library Reprint, p. 162. 
Though of no very great value in themselves, they represent fairly the orthodox opinion of the period.

The earlier of the two is the Theologia Speculativa of Richard Fiddes, the biographer of Wolsey. It was published in I7I8. In treating of the article of the holy catholic church, Fiddes, who acknowledges his obligation to his very good and ingenious friend, Mr Law, observes :

That the church is a distinct society, not only exclusive of unbelievers, but of certain persons professing Christianity, is evident from the sacrament pre-required to their admission into it ${ }^{1}$.

This society is a regular society, in which different functions are assigned to different officers :

The great question is, whether that order of persons, who are now called bishops, be such as supposes they have the supreme power of jurisdiction in the church, and particularly the power of ordaining the clergy, from the apostles... . Nothing is more certain from scripture than that some particular persons only could ordain. This will no more admit of dispute, than whether Timothy was sent to Ephesus, or what was the reason of his going thither; which was, to ordain elders.... [Thus] it is plain...that none can ordain but such as succeed Timothy, or some of his order, in the same commission ${ }^{2}$.

The presbyterians, theoretically, maintain the same doctrine, though they differ from Anglicans as to the meaning of the episcopate.

If they know anything of their own principles, [they] are under an equal obligation with us in general to assert the divine right of the episcopate, in what hands soever it be lodged. The satisfactory way... is to enquire what historical

1 Fiddes, vol. I. p. 567.

2 Ibid. p. 573. 


\section{The Revolution and Since}

authentic evidence we have concerning the distinction of the episcopal order, as we assert it, in opposition to that of presbyters, as asserted by those dissenters, who have been formerly (upon whatever views they are now silent in the controversy) some of the most strenuous asserters of a divine right of succession in the clergy, and of the powers peculiar to them ${ }^{1}$.

From the evidence of Irenaeus, especially, Fiddes concludes :

that...there were particular bishops, so far superior to the order of presbyters in the church, that they alone were reputed the successors of the apostles, and were invested in certain respects with the same ecclesiastical powers in their age that the apostles themselves were originally invested with. So that if ordinations to the sacred office had been unlawful or invalid, either without the authority of the apostles or in opposition to it, they must be equally unlawful or invalid when they are performed either without or against the authority of their successors.... For nothing can properly be meant by a successor of the apostles, but one who succeeds them in certain apostolical powers.... [The ancient writers] all unanimously agree in this conclusion, that bishops are an order superior to presbyters, to whom the supreme power of jurisdiction belonged, and who had the sole power of ordaining others, and that they did accordingly in fact succeed in the episcopate, and alone exercise that power ${ }^{2}$.

Fiddes asserts the unbroken succession in our own church :

As to those who do not derive their ordinations in the same authentic manner, they are here out of the question, and when they are called upon to give an account, by what authority they exercise the sacerdotal powers, or who gave them that authority, must be left to answer for themselves

1 Fiddes, vol. I. p. 574.

2 Ibid. pp. 575 foll. 
as well as they can. We only contend for the necessity of a successive imposition of episcopal hands, wherever the sacerdotal office can be either validly or regularly exercised. It is sufficient to our vindication, that it is so transmitted and exercised in the established church of this kingdom, and that we have good grounds to believe, from the very reason upon which the episcopate was originally instituted, that Christ would continue a succession of it to the end of the world uninterrupted ${ }^{1}$.

In the sequel to this work, which is called Theologia Practica, Fiddes returns to the subject " of the proper officers in the church of Christ." He says :

If we consult the sacred records we shall not find an instance, where any person was invested with this peculiar character, but by the apostles or persons commissioned by them. There are no footsteps of the people's ordaining to the work of the ministry, or of their claiming any such power. ...The succession in each of the three orders was always derived from episcopal hands; and as bishops only had a power to ordain, no ordination by other hands could be, or ever was, admitted as having any force or validity ${ }^{2}$.

Fiddes again touches on the non-episcopal churches :

Whether the necessity pleaded for at the reformation for abolishing the episcopal order was real or only pretended, or however God in cases of necessity may excuse honest and well-meaning persons in the breach of his own constitutions, yet neither in the reason of the thing, nor from any facts recorded in the holy scriptures, can it be proved that facts done by a mere human or other incompetent authority towards conveying any divine powers can be in themselves of the least force or validity.... No such plea [at any rate] can be admitted, or any such favourable allowances
1 Fiddes, vol. I. p. 577.
2 Vol. II. p. 2 I2. 


\section{The Revolution and Since}

made, to unauthorized ordinations where such necessity is not so much as pretended ${ }^{\mathbf{1}}$.

The other Body of Divinity referred to was that of Thomas Stackhouse, first printed in I729, and several times reprinted. Stackhouse has a chapter on Christ's commission to his apostles

which deserves a particular consideration, because on it depends all that power and authority... which the apostles themselves, and after them their successors, claimed and executed in the Christian church $^{2}$.

One of the senses to which the commission may very properly be extended is

As my Father sent me to appoint you my successors, to carry on the work of the gospel when I am gone; so I send you to ordain your successors, that there may not be wanting fit and proper ministers in the church upon your demise ${ }^{3}$.

Stackhouse, a much clearer writer than Fiddes, shows from the apostles' practice and precepts that ministers were always a distinct body of men, and that there were from the first three orders of them. He relies here largely upon the guidance of Comber and of Potter, and upon the argumentative part of Smalridge's sermon above-mentioned.

The farther we go, he says, the clearer the evidence both of the succession and preeminence of bishops appears ${ }^{4}$.

The result is that after the apostles' death

Bishops have by divine appointment, not [by] any voluntary dedition, and to the end of the world ought to have, a power and authority over priests and deacons ${ }^{5}$.

1 Fiddes, vol. II. p. 213.

2 Stackhouse's Body of Divinity, p. 7 I 8 (ed. 2).

3 Ibid.

I Ibid. p. 728 .

5 Ibid. p. 732 . 
After describing various duties of the ministry Stackhouse says :

There are two ecclesiastical offices more; the ordination of such as are appointed to serve in the church; and the confirmation of such as have been baptized and instructed in the Christian faith, both done by the imposition of hands, and both productive to the gifts and graces of the Holy Ghost; which are not, as other ministerial acts, to be performed in common, but are peculiarly the work of the bishops and governors of the church ${ }^{1}$.

After the demise of the apostles

ordination continued where they had left it, in episcopal hands, nor do we find any instance either in scripture or antiquity of inferior orders pretending to that prerogative ${ }^{2}$.

There were not wanting defenders of such convictions even in the highest official ranks of the church of the I8th century. Among these defenders was Isaac Maddox, Bishop of Worcester, who published in I733 his Vindication of the Government, Doctrine, and Worship of the Church of England established in the Reign of Queen Elizabeth.

Neal, in his History of the Puritans, objected to the form of ecclesiastical government which was established under Elizabeth. Maddox defends her choice :

And yet here again the good queen wisely chose not only the most Christian, but the most moderate and catholic scheme of church government. The holy scriptures, and the unquestionable usage of the primitive church, were abundantly sufficient to recommend the appointment of bishops. But as this episcopal form of governing the church

1 Stackhouse's Body of Divinity, p. 739.

${ }^{2}$ Ibid. 
was better suited to the form of the civil government in England (however a different manner might suit the little republic of Geneva); as most of the reformed churches in Germany had the same form in effect, changing only the old Greek names (as Zanchius reporteth) of archbishops and bishops into new and worse Latin names of superintendents and general superintendents; as the more moderate Calvinists, and their great leader Calvin himself, allowed of this superiority of bishops, and thought it very useful... 1 .

The thread of Maddox's sentence is broken off, but he returns to say that Neal accused Elizabeth and her advisers of departing from the Edwardian divines, who did not receive the doctrine of a difference of order between bishops and priests.

By this account 'tis plain $\mathrm{Mr} \mathrm{N}$. would have it believed that bishop and priest were in the opinion of the first reformers synonymous terms, signifying not only the same order, but the same office too ; being, as he says, but two names of the same office. His material proof is the public ordinal ; and to be sure, if anywhere, the reformers speak distinctly, when they are designedly treating upon this subject, and appointing the very forms of ordination and consecration. Here then we join issue, and both appeal to the same ordinal, as a decisive proof ${ }^{2}$.

Maddox puts Neal's words side by side with the opening sentence of the preface, and says

Without stopping for one reflection, let us go on to his next assertion, which runs thus: "The form of ordaining a priest and a bishop is the same."

He exposes this absurdity, and goes on :

Nothing, sure, but the impossibility of supporting his scheme, and proving the parity of presbyters and bishops any other way, could have put Mr N. upon this method of 1 Maddox's Vindication, pp. 53 foll.

$=$ Ibid. p. 59. M. 
attempting it. He had indeed undertaken a difficult task, and must therefore have great allowances in the execution of it. The sense and practice of the whole Christian church for fifteen hundred years in a form of church government so early, so universally, so constantly received, were great obstacles. No instances of presbyters executing the distinguishing offices of a bishop, no example of any man's being a bishop one day and reduced to a mere presbyter the next, as must have been the case, had a bishop, as is sometimes alleged, been no more than a chairman, a moderator, or temporary president of a presbytery. No instances of many bishops in places where there were many priests; on the contrary, we always find one particular person mentioned as the bishop, and sole bishop, of one particular city, even where there were many presbyters. This being the case, and the promiscuous use of names not sufficient to overcome so many arguments, or show the identity of order and office between a bishop and priest, any more than an apostle's calling himself a deacon will prove the apostolate and deaconship to be one order; other methods were to be tried, and the very form of consecrating a bishop, who had before been ordained a priest, be employed to prove there was, in the opinion of the compilers of that form, no such order as bishops in the church, all mere presbyters and nothing more ; not only the same order, but the very office the same'.

Then Maddox quotes from Burnet's History of the Reformation a useful passage, exposing the error of those who used the two-order theory as an engine of attack upon the church of England. The passage is this :

In the ancient church they knew none of those subtilties which were found out in the latter ages. It was then thought enough that a bishop was to be dedicated to his function by a new imposition of hands, and that several

1 Maddox's Vindication, pp. 63 foll. 


\section{The Revolution and Since}

offices could not be performed without bishops, such as ordination, confirmation, etc., but they did not refine in these matters so much as to enquire whether bishops and priests differed in order and office, or only in degree.... The schoolmen...raised [the priest's] order or office so high, as to make it equal with the order of a bishop; but as they [the schoolmen] designed to extol the order of priesthood, so the canonists had as great a mind to depress the episcopal order....

On this I have insisted the more [Maddox is still quoting from Burnet], that it may appear how little they have considered things, who are so far carried with their zeal against the established government of this church, as to make much use of some passages of the schoolmen and canonists, that deny them to be distinct offices. For these are the very dregs of popery ${ }^{\mathbf{1}}$.

Perhaps Archbishop Secker is not one of those to whom we should naturally turn for illustration to the subject of which we are treating. Yet Secker, like his friends Butler and Benson, was a convert to the church, and knew, like them, what the church meant. In I764 he printed a defence of the Society for the Propagation of the Gospel against an American dissenter, who objected to the sending of bishops, or of episcopal clergy, into some of the American colonies, as contrary to what we now call the comity of missions.

Dr Mayhew's book is written, partly against the church of England in general; partly against the conduct of the Society for the Propagation of the Gospel in settling ministers of that church in the Massachusetts and Connecticut; partly against appointing bishops to reside in his Majesty's American colonies...2.

1 Burnet History of the Reformation (ed. Pocock), vol. I. pp. 396 foll.

2 Secker's Nine Sermons (3rd ed.), p. 239. 
His charge on the Society is that they have maintained episcopal churches where other protestant churches were before settled and the administration of God's word and ordinances provided for, with a formal design, which they have long had, to root out presbyterianism etc. in the colonies. Now this design, in pursuance of which, he saith, they have in a great measure neglected the ends of their institution, is falsely ascribed to them.... Undoubtedly they would be very glad if all the inhabitants were of the communion of the church of England; as undoubtedly the doctor would if they were all of his communion. But they have sent no persons to effect this. He attempts to prove the contrary from the following instruction given by them to their missionaries; "That they frequently visit their respective parishioners; those of our own communion, to keep them steady in the profession and practice of religion as taught in the church of England; those that oppose us or dissent from us, to convince and reclaim them with a spirit of meekness and gentleness...." The instruction plainly relates, not to missionaries settled in presbyterian or congregational parishes, for there were none so settled when it was drawn up, but for incumbents of episcopal parishes, though with a mixture of dissenters... ${ }^{1}$.

The real conduct of the Society, with respect to provinces and parishes not episcopal, hath been to contribute towards supporting public worship and instruction amongst such members of the church of England as cannot in conscience comply with the worship and instruction of the other congregations in the neighbourhood, and yet cannot wholly maintain ministers for themselves.... And were it but known, as it seems to be in some measure to the dissenters themselves, how continual and importunate the calls and expostulations of such persons are, the impartial would wonder how the Society could withstand so many of them as it hath done ${ }^{2}$.

\footnotetext{
1 Secker's Nine Sermons, p. 250.

2 Ibid. p. 254.
} 
But the doctor apprehends that...conscience is seldom their motive, and therefore they should not be encouraged. Indeed he scarcely seems to conceive how it can be their motive, and wants to be told "what there is that should give offence to good protestants" in the presbyterian or congregational churches....He recollects that he hath heard some episcopalians say, that they should much prefer the communion of the church of Rome to that of the dissenters. And indeed none are so likely as he, and such as he, to provoke those into saying it, who would think very differently in their cooler hours. But supposing this to be their settled judgment, would he have them left to turn papists, if they will, because they are not so good protestants as they should be ${ }^{1}$ ?...

He admits that some of [the episcopalians] may possibly, without going these lengths, have conscientious scruples about the means of religion in his communion. But he puts the word "possibly" in italics; which intimates that he thinks it barely possible.... We hold it to be probable, we hold it to be evident, that many dissenters, who are far from thinking us worse than papists, yet cannot in conscience use the means of religion in our communion; and surely we are entitled to as favourable an opinion from them. Without maintaining that they have no gospel ministers, or sacraments, or ordinances, or churches, we may apprehend,- whether rightly or wrongly is not to be disputed now, but sincerely, however-that episcopacy is of apostolical institution, and that scripture affords as good proof of this as of the appointment of infant baptism and the - Lord's day. We may apprehend that after the ceasing of extraordinary spiritual gifts forms of prayer were always used, more or less, throughout the church of Christ and are needful for the observance of the scripture rule, Let all things be done decently and in order. Without judging those who reject both these (for to their own Master they stand or fall) we may judge it unlawful for us to join in the

${ }^{1}$ Secker's Nine Sermons, pp. 259 foll. 
rejection of either. Nay, were we only to think their ministry, compared with that of our church, to be unedifying, and make that our plea for preserving a separation from them, we should but follow the pattern which many of the English dissenters have set ${ }^{1}$.

The age of Law and Wilson, Secker and Maddox, was also the age of Wesley. It was one of the extraordinary features in the character of that great man, that he was able to persuade himself that he was a loyal and consistent churchman throughout his long life. It is at any rate certain that his opinions on the subject of ordination underwent a change. In the year I745 he wrote a letter to his brother-in-law, Hall, expressing as clearly as possible the doctrine which he might have learned from Law :

We believe it would not be right for us to administer either baptism or the Lord's Supper, unless we had a commission so to do from those bishops whom we apprehend to be in a succession from the apostles.

We believe there is, and always was, in every Christian church, whether dependent on the Bishop of Rome or not, an outward priesthood, ordained by Jesus Christ, and an outward sacrifice offered therein, by men authorized to act as ambassadors of Christ and stewards of the mysteries of God.

We believe that the threefold order of ministers is not only authorized by its apostolical institution, but also by the written word ${ }^{2}$.

When he penned these sentences, he was on the eve of change. About 50 years before, a youth of 22, named Peter King, who afterwards rose to be

1 Secker's Nine Sermons, pp. 26r foll.

2 Tyerman's Life and Times of John Wesley, vol. r. p. 496. 
Lord High Chancellor, wrote a book on the Primitive Church, in which with juvenile self-confidence he demolished the order of bishops - a feat which in later life he repented of. This book Wesley read on the way to Bristol in January I746. After reading it, he wrote in his journal:

In spite of the vehement prejudice of my education, I was ready to believe that this was a fair and impartial draft ; but if so, it would follow that bishops and presbyters are essentially of one order, and that originally every Christian congregation was a church independent of all others ${ }^{1}$.

The minutes of the Methodist conference of the ensuing year (I747) betray the change of mind.

$Q$. Are the three orders of bishops, priests, and deacons, plainly described in the New Testament?

$A$. We think they are, and believe they generally obtained in the churches of the apostolic age.

$Q$. But are you assured that God designed the same plan should obtain in all churches, throughout all ages ?

$A$. We are not assured of this, because we do not know that it is asserted in holy writ.

$Q$. If this plan were essential to a Christian church, what must become of all the foreign reformed churches?

$A$. It would follow that they are no parts of the church of Christ, - a consequence full of shocking absurdity.

$Q$. In what age was the divine right of episcopacy first asserted in England?

$A$. About the middle of Queen Elizabeth's reign. Till then, all the bishops and clergy in England continually allowed and joined in the ministrations of those who were not episcopally ordained ${ }^{2}$.

1 Tyerman's Life and Times of John Wesley, vol. I. p. 508.

${ }^{2}$ Ibid. p. 509. 
By the year I756, Wesley's reading had been enlarged by another youthful book, also subsequently censured by its author :

I still believe the episcopal form of church government to be scriptural and apostolical;-I mean, well agreeing with the practice and writings of the apostles. But that it is prescribed in scripture I do not believe. This opinion, which I once zealously espoused, I have been heartily ashamed of ever since I read Bishop Stillingfleet's Irenicon. I think he has unanswerably proved that neither Christ nor his apostles prescribe any particular form of church government, and that the plea of divine right for diocesan episcopacy was never heard of in the primitive church.

As to...schism, I cannot find one text in the bible, where... schism signifies a separation from the church, whether with cause or without ${ }^{1}$.

It was long before Wesley made up his mind to act upon this conviction, but the conviction grew. In $\mathrm{I} 780$ he wrote to his brother :

Read Bishop Stillingfleet's Irenicon, or any impartial history of the ancient church, and I believe you will think as I do. I verily believe I have as good a right to ordain, as to administer the Lord's Supper. But I see abundance of reasons why I should not use that right, unless I was turned out of the church. At present we are just in our places ${ }^{2}$.

Four years later, by the imposition of his hands, he set apart Dr Coke, who was a priest like himself, " as a superintendent," with a view to his ordaining methodists in America.

1 Tyerman's Life and Times of John Wesley, vol. II. p. 244.

2 Ibid. vol. III. p. 332. 


\section{The Revolution and Since.}

If anyone is pleased to call this separating from the church (he wrote), he may. But the law of England does not call it so; nor can anyone properly be said so to do, unless out of conscience he refuses to join in the [church] service and partake of the sacraments administered therein ${ }^{1}$.

This act was quickly followed by ordaining methodists for work in England, but John Wesley would not realise that the action was schismatical. His biographer, who rejects the church theory of ordination, describes the position very fairly:

The right or wrong of ordaining is left to others to discuss. There can be no doubt that as a minister of Christ Wesley had as much right to ordain as any bishop, priest, or presbytery in existence; but he had no right to this as a clergyman of the church of England, and by acting as he did he became, what he was unwilling to acknowledge, a dissenter, a separatist from that church. Such was the opinion of Lord Mansfield; and such was the argument of Wesley's brother. Wesley refused to acknowledge this; but feeling the impossibility of the thing, he declined to attempt refuting it. With great inconsistency, he still persisted in calling himself a member of the church of England, and... to the day of his death told the methodists that if they left the church, they would leave him. All things considered, this was not surprising; but it was absurd ${ }^{2}$.

It may be added that it was not because Wesley was only a presbyter, that his ordinations meant separation. If he had been in the fullest ecclesiastical sense a bishop, his ordinations would have been no less schismatic, though they would have had a greater claim to be considered valid.

1 Tyerman's Life and Times of John Wesley, vol. III. p. 436.

2 Ibid. p. 448. 
In his well-known sermon on the Ministerial Office, preached in 1789 , which is still part of the legal formularies of methodism, Wesley declaims against the methodist preachers who "like Korah, Dathan, and Abiram, seek the priesthood also'."

When Wesley's action became known, it naturally gave deep offence to churchmen, even among those who were more or less favourably disposed towards him. George Horne, Bishop of Norwich, spoke of it in his Charge to the clergy of the diocese in I79I. He lays down the principle that

[The gospel ordinances] can no man minister to effect but by God's own appointment : at first by his immediate appointment, and afterwards by succession and derivation from thence to the end of the world. Without this rule we are open to imposture, and can be sure of nothing; we cannot be sure that our ministry is effective, or that our sacraments are realities. We are very sensible that the spirit of division will never admit this doctrine, yet the spirit of charity must never part with it. Writers and teachers who make it a point to give no offence treat these things very tenderly; but he who in certain cases will give no offence to men, will for that reason give them no instruction.

He proceeds to consider Wesley's action :

We are informed that the liberties taken of late years against the ministry of the church have terminated in an attempt to begin a spurious episcopacy in America.... $\mathrm{Mr}$ Wesley, when questioned about this fact in his lifetime, did not deny it, but pleaded necessity to justify the measure. ...A fatal precedent, if it should be followed. For if a presbyter can consecrate a bishop, we admit that a man may

1 Sermon cxv. 
confer a power of which he is not himself possessed : instead of the less being blessed by the greater, the greater is blessed by the less, and the order of all things is inverted ${ }^{1}$.

Horne was probably unaware of Wesley's ordination of presbyters for work in England, or he would have spoken with equal plainness of it. William Jones, of Nayland, records the occasion when $\mathrm{Mr}$ Wesley "was questioned " about the American commission, and adds the following comment :

There are but two possible ways of putting men truly into the ministry : the one is by succession; the other by immediate revelation or appointment from God himself. Paul received his commission to preach, not of man nor by man, but of God, who put him into the ministry. Other ministers of the Gospel receive their commission by imposition of hands from those who had received it before. In this latter way of succession no man can possibly give that which he hath not received.... And as this could not be done by Mr Wesley in virtue of what he was, it must have been done in virtue of what he thought himself to be; a vicar-general of heaven, who was above all human rules, and could give a commission by a superior right vested in his own person. If he acted of himself, as John Wesley, a presbyter of the church of England, he acted against all sense and order; and by taking upon himself what no man can take, he would introduce in the issue more confusion than he would prevent ${ }^{2}$.

In the same year (I79I) that Horne was charging the clergy of Norwich about methodism, Samuel Horsley was doing the same to the clergy of St David's. He thought that more teaching should be given on the subject of church authority.

1 Horne's Works, vol. II. p. 570.

2 Life of Dr Horne, p. 158. 
Upon these topics the clergy of late years have been more silent than is perfectly consistent with their duty; from a fear, as I conceive, of acquiring the name and reputation of high-churchmen.... To be a high-churchman, in the only sense which the word can be allowed to bear as applicable to any in the present day,-God forbid that this should ever cease to be my public pretension, my pride, my glory !... In the language of our modern sectaries, everyone is a high-churchman who is not unwilling to recognise so much as the spiritual authority of the priesthond,--everyone who, denying what we ourselves disclaim, anything of a divine right to temporalities, acknowledges however in the sacred character somewhat more divine than may belong to the mere hired servants of the state or of the laity, and regards the service which we are thought to perform for our pay as something more than a part to be gravely played in the drama of human politics. My reverend brethren, we must be content to be highchurchmen according to this usage of the word, or we cannot be churchmen at all ; for he who thinks of God's ministers as the mere servants of the state, is out of the churchsevered from it by a kind of self-excommunication.... For those who have been nurtured in the bosom of the church, and have gained admission to the ministry, if, from a mean compliance with the humour of the age, or ambitious of the fame of liberality of sentiment,...they affect to join in the disavowal of the authority which they share, or are silent when the validity of their divine commission is called in question,-for any (I hope they are few) who hide this weakness of faith, this poverty of religious principle, under the attire of a gown and cassock, they are in my estimation little better than infidels in masquerade ${ }^{1}$.

To fortify his clergy on the subject of the deference due from the private Christian to the authority of the church, and to a ministry of divine institution, 1 Charges of Samuel Horsley (1830), pp. 28 foll. 
Horsley recommends them to make the Apostolical Fathers, especially St Clement and St Ignatius, their constant study; and, with these, the writings of Hooker, Charles Leslie, and Jones of Nayland.

The book of Jones to which Horsley refers in particular is his Essay on the Church. Jones was moved to write it by his experience in catechizing the children of his parish, and feeling himself somewhat at a loss because the catechism contains no instruction on the church. The church must, he says, in its nature be a society manifest to all men. As a society, it is not the work of man : it is the church of the living God and acts by his authority and appointment.

The church must have orders in it for the work of the ministry; but no man can ordain himself, neither can he, of himself, ordain another, because no man can give what he hath not.... No ambassador ever sent himself, or took upon him to sign or seal treaties and covenants (such as the sacraments of the church are) without being sent; that is without receiving authority so to do from an higher power. The act would be so far from beneficial, that it would be treasonable ${ }^{1}$.

Quoting Law's second letter to the Bishop of Bangor, Jones gives an account of the institution of the ministry which begins thus :

Jesus Christ was sent from heaven by the Father, and invested with the glory of the priesthood by an actual consecration, when the Spirit descended upon him. As the Father hath sent him, so did he send his disciples, and gave them authority to send others; so that the church which followed derived its authority from the church which Christ

1 Works, vol. Iv. p. 418. 
first planted in the world; and the church at this day must derive its authority after the same manner, by succession from the church which went before; the line extending from Christ himself to the end of the world. Lo, said he, I am with you always, unto the end of the world ;certainly not with these very persons, who all soon died, but with those who should succeed, and be accounted for the same ; for a body corporate never dies, till its succession is extinct ${ }^{1}$....

That the apostles appointed others to succeed to their own order is evident from the case of Timothy; who in the ancient superscription at the end of the second epistle is said to have been ordained the first bishop of the church of the Ephesians. He is admonished to lay hands suddenly on no man; and... not to receive an accusation against an elder but before two or three witnesses: therefore he had a judicial authority over that order. Directions are given with respect to the deacons of the same church. Therefore in the first church of the Ephesians there was a bishop, with elders and deacons under him.... In the Christian church throughout the world we find these three orders of ministers for fifteen hundred years, without interruption. The fact therefore is undeniable, that the church has been governed by bishops, priests, and deacons from the apostles downwards; and where we find these orders of ministers duly appointed, the word preached, and the sacraments administered, there we find the church of Christ, with its form, and its authority ${ }^{2}$.

One of the most popular religious books of the close of the I8th century was Charles Daubeny's Guide to the Church (I798). It is, as its name implies, a series of instructions intended to lead dissenters to the church. In a prefatory address to William Wilberforce, whose views did not altogether commend

1 Works, vol. IV. p. 422.

2 Ibid. p. 424. 
themselves to Daubeny, the author laments the prevailing ignorance on the subject among the laity:

The forming of a correct notion of the church, as a spiritual society under the regular establishment of its divine Founder, I consider to be a part of that knowledge which every member of it ought to possess. At the same time I cannot help regarding it as a circumstance most to be lamented, that in consequence of the prevailing ignorance upon this subject the clergy of the present day should be called upon to examine foundations, which by wise masterbuilders have so long since been firmly laid.

Daubeny agrees that the gospels do not prescribe the constitution of this society, but it is none the less divine :

What form of government the apostles agreed to establish in the church, if not expressly communicated to them by Christ in person, must be considered established under the direction of the Holy Spirit.... What that form of government was, we shall be at no loss to determine, if we are disposed to enquire fairly into the subject ${ }^{1}$.

If scripture did not make it plain, the practice of the primitive church would do so; for

it is a known axiom that every law is best explained by the subsequent practice. Let this maxim be applied in the present case $^{2}$.

He quotes the " bold and peremptory" language of Hooker ${ }^{3}$, and says :

If we say then that in every church that was planted, the offices of bishop, priest, and deacon, answering to those of high priest, priest, and levite under the law, were to be found, we shall say no more than the history of the primitive church will warrant ${ }^{4}$.

1 Guide to the Church, p. $27 . \quad 2$ Ibid. p. 28.

See above, p. 57 .

4 Guide to the Church, p. $3 \mathrm{I}$. 


\section{The Revolution and Since}

This constitution is to last till the end :

The church is not merely a number of people, agreeing in the same articles of faith, or in the same acts of religious worship ; but it is moreover a society, holding one visible communion under the same divinely instituted government : a society not of man's, but of Christ's forming; a society or spiritual incorporation of which he is the Head, and all individual Christians, who have been regularly admitted into it, the members. For the church is not a creature of the fancy, deriving an imaginary existence from the whim and caprice of man, but a settled and permanent establishment, the work of divine wisdom. It is moreover not hid in a corner, that men need be at a loss to find it; but a visible society, possessed of those characteristic marks, by which it may at all times be known ${ }^{1}$.

Daubeny expounds the metaphors under which it is described in scripture, and goes on :

Such then is the nature and constitution of the church, as it was originally established by its supreme Head, from whence the apostles, and their successors the bishops, have derived their commission; a branch of that commission which Jesus Christ received from his Father; by virtue of which they challenge obedience from every member of the Christian church, as to the stewards or chief officers in that spiritual society, over which they are authorized to preside ${ }^{2}$. The term " schism," Daubeny says,

denotes a division among the members of which that body is composed; occasioned by a want of obedience to the government which Christ by his apostles settled in the church ; and a consequent separation from its communion, in contradiction to the divine plan of its establishment; the design of which was that all Christians should be joined together in the same mind and in the same worship, continuing, according to the primitive pattern, in the apostles'

1 Guide to the Church, p. 35.

2 Ibid. p. 37. 
doctrine and fellowship, and in breaking of bread, and in prayers ${ }^{1}$.

Thus schism is " a species of rebellion" against the divine founder of the church :

Custom has indeed so far reconciled us to the divisions that have taken place among Christians, that they are no longer seen in the light in which they were seen in the primitive days of the church; whilst charity, forbidding us to speak harshly of the spiritual condition of our brethren, has in a manner tended to efface the sin of schism from our minds. But, though we presume to judge no man... yet must it not from hence be concluded that it is a matter of indifference, whether Christians communicate with the church or not; or that there is a doubt upon the subject of schism, whether it be a sin or not ${ }^{2}$.

The dissenter argues that in separating from the church of England he only does what the church of England itself has done with regard to Rome. Here is the answer :

Ever since the era of the reformation, the church of England has been considered to be the firmest bulwark of protestantism. So far as the dissenter agrees with her in protesting against the errors of the Romish church, so far he may be said to be at unity with her. But when that right, which justifies the dissenter in common with the church of England in separating from a corrupt branch of the Christian church, is extended to justify his separation from a branch of the church confessedly not in the same state of corruption, and of whose members no unlawful terms of communion are required, and to authorise his setting up a church of his own, independent of episcopal government, the dissenter quits the original ground of protestantism, and places himself upon that of schism;

1 Guide to the Church, p. 42.

2 Ibid. p. 44. M. 
and in such case he becomes a schismatic grafted upon a protestant ${ }^{1}$.

Daubeny describes the "disadvantages " of separation in the language of Law :

When you leave the church then, it should be remembered, you leave the ministers and sacraments of Christ behind you. You may indeed appoint other ministers, and institute other sacraments; but let it be observed, these ministers are not the ambassadors of Christ, nor are the sacraments which they administer the sacraments of Christ ; for the essence of an ambassador's office is that he should be commissioned by the party whom he represents, and the essence of a covenant, of which the sacraments are seals, is that it should be binding upon the party in whose name it is made. But ministers of the separation are not ambassadors of Christ, because they have never been sent by him; and with respect to the benefit to be derived from the sacraments administered by them, their disciples must not look to God, for this obvious reason, because God is not bound but by covenants of his own making 2 .

\section{Daubeny writes a "postscript" to "occasional} separatists.'

Occasional separation from the church stands in point of argument on the same ground with occasional conformity to it. If conformity to the church be a sin against the conscience of the party, which was the plea originally set up by those who separated from it in this country, every act of occasional conformity, being a commission of that sin, must be subject to condemnation. [Similarly] if schism, or a wilful separation from the church be in itself a sin, as from the authority of scripture and the primitive writers of the church it is adjudged to be, every occasional separation from it must be seen in a similar point of view. It is a commission of an acknowledged sin; and the only

1 Guide to the Church, p. 152.

2 Ibid. p. I79. 


\section{The Revolution ana Since}

difference between the constant separatist and the occasional one appears to be that the one continues in the habitual practice of that sin, which the other occasionally commits ${ }^{1}$.

Wilberforce in his Practical View had urged upon true Christians to cultivate " a catholic spirit of amicable fellowship" towards all, of whatever sect or denomination, "who, differing from them in nonessentials," agree " in the grand fundamentals of religion." Daubeny, of course, applauds the sentiment, but asks pertinently enough what " the grand fundamentals" are.

Is everything relating to the church of Christ to be deemed non-essential, save what respects the profession of its peculiar doctrines?... Upon this supposition... the conclusion which... readers will draw... will be this; that provided they believe what as Christians they must believe, it is a matter of no consequence what form of religious worship they adopt; whether they hold communion with the church or the meeting house; in other words, whether they assemble as members of the church of Christ, or as members of a schismatic congregation. The admission of this idea cuts up by the roots the unity of the Christian church, and makes what the apostles and first Christians wrote upon this subject something worse than nonsense; for in this case they imposed on their fellow Christians, by making matters in themselves indifferent subjects of very important consideration. In short, this intercommunion (if we may so say) between the church and the conventicle, so utterly inconsistent with the regular economy of divine grace, can never lead to good.... Upon what ground.... are we to conclude that conformity to the established government of the church, which in the primitive days constituted a subject of the first magnitude,

1 Guide to the Church, p. 273. 
is now dwindled down into an unimportant consideration? Can anything which has received the sanction of a divine institution in religion be deemed a non-essential ${ }^{1}$ ?

Daubeny followed up his Guide by an Appendix, in two volumes (I799), consisting of letters to Sir Richard Hill in detailed defence of the position taken up in the Guide. The second letter is mainly occupied with a statement of the early history of episcopacy,-acute and well-informed, but not requiring our special attention, unless it be for a remark like the following, which shows what may be called the historic imagination :

From the premises...we are justified in concluding that all those singular ecclesiastical governors, who received a commission similar to that received by Timothy and Titus, had sundry parts of the apostolic sovereign power conferred upon them, which had never been imparted to presbyters in common. On taking possession of the churches thus committed to their charge, they must find presbyters, ministering in that capacity, in which they had been accustomed to minister under the apostolic supremacy. On the reception of these new commissioned governors amongst them, the presbyters must have been convinced by those reserved apostolic powers of ruling, ordination, and censure,...that they were authorized to succeed in the ordinary jurisdiction and prerogatives of their departing apostle ${ }^{2}$.

Daubeny made no doubt that his doctrine was the old doctrine of the church, and nothing novel :

This catholic doctrine, Sir, respecting the divine original of the episcopal office and the spiritual government in the kingdom of Christ, though liable to abuse (and what doctrine

1 Guide to the Church, pp. 346-349.

2 Appendix, vol. I. p. 77. 


\section{The Revolution and Since}

is not ?) was acknowledged without scruple by Christians of all ranks, as well after as before the empire turned Christian; when emperors, not less than their subjects, submitted themselves to their bishops, as to their spiritual superiors ${ }^{1}$.

$\mathrm{He}$ was as exclusive as any later divine in his employment of the word " a church" :

Every Christian society, possessing the characteristic marks of the church of Christ, I consider to be a separate branch of the catholic or universal visible church upon earth. The church of England, the church of Ireland, and the episcopal church of Scotland and America, possess these marks. In the same light the churches of Denmark, Sweden, and Rome are to be considered ${ }^{2}$; not to mention the great remains of the once famous Greek church, now to be found in the empire of Russia and in the east. All these churches constitute so many branches of the same catholic church of Christ; independent of each other, so far as relates to the direction and appointment of indifferent things, as rites and ceremonies; but connected together as one body, by the profession of the same fundamental articles of faith and the same divinely instituted form of government ${ }^{3}$.

In a later letter Daubeny returns to the subject of the apostolical succession :

One of the principal considerations necessary to be impressed upon the mind of the reader upon this occasion was the commission, from which the act of the minister of the church derived its validity, for the benefit of the parties concerned in it. The commission to administer the sacraments of the church was originally delivered by our

1 Appendix, vol. I. p. 84 .

2 Daubeny was probably unaware of the facts with regard to the Danish episcopate.

${ }^{3}$ Appendix, vol. I. p. I30. 
Saviour to his apostles, accompanied with a power to invest others with the same important office. From this divine fountain all authority in this case must be derived.... A regular reception of the divine commission, through the channel appointed to convey it, has been a circumstance which in every age of the church, from the times of the apostles down to the present day, has been considered essential to the validity of the ministerial office....

If then a commission was granted to particular persons for an especial purpose, and a blessing promised to the actual discharge of it, that blessing must be understood to be co-extensive only with the due discharge of the commission for which it was granted, unless it can be proved that in consequence of some new revelation from heaven the nature of that commission has been changed.... But the visible church of Christ, which has continued under the same episcopal form of government from the beginning, knows that there has been no new revelation and that no circumstances have taken place to justify any alteration in this case.... Upon these grounds, therefore, it is concluded that the blessing originally promised to the regular discharge of the evangelic ministry is confined to that discharge of it...and it is in conformity with this idea, which has prevailed in the church from the days of the apostles down to the present times; namely, that it is the commission which secures the divine confirmation of the ministerial act, that the sacraments administered in the church have been considered as the only valid sacraments ${ }^{1}$.

That Daubeny's teaching was not foreign to the general beliefs of contemporary churchmen may be gathered from the fact that the University of Oxford conferred upon him the degree of Doctor of Divinity, in recognition of his services to the church $^{2}$.

1 Appendix, vol. I. pp. 352-358.

2 See the article on him in Dict. of Nat. Biography. 
A work of similar character to Daubeny's was Thomas Sikes's Discourse on Parochial Communion, published in I8I2. Sikes was himself a man of light and leading, and his connexion with the well-known Joshua Watson, who married his daughter, conveyed his influence to a large circle of churchmen. His book is a plain straightforward treatise on episcopacy and unity, viewed in reference to the parochial system.

If the sacred character and divine authority of the Christian priesthood were correctly understood, it begins, it would greatly conduce to the prevention of those many divisions which at present distract the church of Christ. There are no other means of accomplishing this end, but those of frequent instruction on the subject, and of plainly enforcing the duty of submission to the episcopal authority.

The main doctrine of the book is thus summed up :

Every bishop receives his commission and, with it, his spiritual authority immediately from those bishops who consecrated him, as they derived their powers and privileges from their predecessors, in a direct line from the apostles and our Lord. Our Lord bequeathed his authority to his apostles and their successors to the end of the world.... That is, he left with them his commission and his Spirit for their natural life, entailing them upon that succession of men, upon whom they should lay their hands according to his direction ${ }^{1}$.

Sikes starts with the affirmation that a belief in the holy catholic church is part of the universal creed of Christendom.

1 Discourse on Parochial Communion, p. 5. 
But it is further necessary that we believe this article, not in some loose and general acceptation, but in that alone which was intended by the Founder....We do not leave it to the Socinian to believe in a Redeemer in the sense which pleases him: we do not admit the Quaker's notions of the Holy Spirit ; nor will every acceptation of this article be sufficient to constitute it a true Christian faith. It must be received in its one proper sense, which must be sought by a careful study, first of the sacred scriptures, and afterwards... of the writings of those holy Christians, who living nearest to the days of our blessed Lord and his apostles are the best interpreters of their designs and intentions ${ }^{1}$.

\section{He quotes with relish the saying of Pearson}

That church alone, which first began at Jerusalem on earth, will bring us to the Jerusalem in heaven.... Whatsoever church pretendeth to a new beginning, pretendeth at the same time to a new churchdom, and whatsoever is so new, is none ${ }^{2}$.

Sikes sketches the history of the ministry in the New Testament, and goes on :

From the apostles, then, descending to their successors, some of whom conversed with them and were their disciples, we find that the succession of bishops, and the government of the church by them, still prevailed wherever the gospel was planted ${ }^{3}$.

After giving patristic evidence down to the time of St Austin, he says :

It would be tedious and unnecessary to bring the episcopal succession further downwards. From this time "in toto orbe decretum est," says Jerome; episcopacy

1 Discourse on Parochial Communion, p. 13.
${ }^{2}$ Ibid. p. 18.
3 Ibid. p. 43. 
became the universal mode of Christianity....He who would look for Christianity without bishops may as well look for it without sacraments ${ }^{1}$.

Sikes enquires into the nature of " the pastor's right to minister to the people," and draws very clearly the distinction between order and mission. With evident reference to the famous interview between Wesley and Bishop Butler, he speaks severely of the "saucy itinerant" who takes the whole world for his parish on the ground that he was made a priest of the universal church ${ }^{2}$.

No clergyman, he says, has the liberty of officiating where he pleases, and to whom he pleases; he cannot do it in this kingdom without intrusion upon the cure of other ministers ; for all Christians within the pale of our English church are dispersed into different congregations, and have been regularly committed, by the authority which bishops derive from the divine Head of the church, to the charge of their several ministers.... The selfwilled man, who disregards the prescribed order of the church, and pretends to officiate to persons not committed to his charge, is guilty of intrusion, as well as he who ministers in places to which he has not been regularly deputed ${ }^{3}$.

It is a " wild and factious spirit" which animates every such intruder,

whether he be found in the ranks of the established church, or in those of the separatists; whether he practise the more generous manner of openly dissenting from the church, or the insidious mode of assuming the form of a "true churchman"; whether he go abroad to gather congregations, or remain at home, calling them into his own church... ${ }^{4}$.

1 Discourse on Parochial Communion, p. 54.

${ }^{2}$ Ibid. p. $258 . \quad 3$ Ibid. pp. 238 foll. $\quad$ Ibid. p. 290. 
He who despises this power of mission, which bishops always possessed, despises episcopacy ; and if he despise the episcopal authority, he despises him from whom it is derived $^{1}$.

Sikes, like Daubeny, has a word for the " occasional communicant" in dissenting congregations:

The occasional communicant at the meeting house is necessarily only an occasional communicant at the church. Communion is a habit; and that which breaks the habit, breaks communion. Whatever is only occasional is not communion, and whatever is communion is not occasional. We should think it rather strange in a man professing his regard for humility or for chastity to talk of occasional pride, or occasional whoredom ; for these virtues are habits, and whatever destroys the habit...destroys the virtue. Occasional pride destroys humility; occasional whoredom destroys chastity; occasional schism destroys communion. The occasional communicant is such an amphibious religionist as cannot, by the principles of church communion, be considered as a churchman. ... Occasional communion... has been...peculiar to our separatists; a practice always much opposed by the churchmen, and considered by them as disgraceful and indefensible ${ }^{2}$.

The downright catholicism of Daubeny and Sikes was not so uncommon in the English church of their time as is often thought. A man like Shute Barrington, for instance, Bishop of Durham, could speak of reunion between Rome and "the catholics of the church of England" as the greatest blessing that could befall Christendom,- - though he did not minimize the gravity of Roman errors. His successor, Van Mildert, again and again preaches the via media

1 Discourse on Parochial Communion, p. 350.

2 Ibid. p. 379. 


\section{The Revolution and Since}

of Anglicanism in the same way as the Caroline divines did. Our liturgy, he says, "preserves the most happy medium" between extremes. "We trace in it nothing of the hostility of sectarian prejudice; nothing of rash and crude innovation." Our reformers purified the older service books, but " by no means abandoning the whole, as if nothing that the church of Rome had approved might be tolerated by a protestant community." The preface to the prayer-book, as Van Mildert points out, lays claim to this virtue.

The spirit which animated some other of the reformed churches was not altogether of so unexceptionable a character.... The primitive ordinances, and even the primitive faith, of the purest ages of Christianity were in several instances rudely shaken, or inconsiderately abandoned. In some episcopacy was abolished, and with it many essential qualifications of the priesthood....Almost all, in some particulars, relinquished usages sanctioned by primitive, nay, even apostolical practice. Nor can we observe without regret, that the greater part of those heresies and schisms, which gave the enemies of the reformation so great occasion to bring it into discredit, were the offspring of those churches, who by carrying the supposed work of reformation too far... loosened the very principles on which it ought to have rested ${ }^{1}$.

\section{In another sermon he says :}

It is a cold and cheerless kind of philosophy...that affects to undervalue the outward forms and modes and decencies of religious worship.... Nor is it much less erroneous to regard as a matter of indifference, where, and by whom, the public ministrations of religion shall be performed; whether under the sanction and direction of

1 Theological Works (ed. I838), vol. I. p. I7I. 
long established usage, derived from scripture and from the primitive practice of the apostles and their successors, or with no other security than the variable opinions of self-appointed teachers, or the continual fluctuations of mere human judgment. I mean nothing invidious towards those who differ from us in their views of this subject, when I earnestly entreat you, my brethren, as professed members of our church, duly to appreciate the advantages you enjoy,... with the scriptures continually read to you, with a duly ordained and competently learned ministry to preach and expound them, with a liturgy truly scriptural, ...having also the sacraments... rightly and duly administered for your comfort and support.... While therefore we charitably leave to others full liberty of conscience to worship God according to their own sincere persuasions, however different from our own, be it our concern to show both our sincerity and our thankfulness... by a steadfast adherence to the communion in which we have been brought up and nurtured ${ }^{1}$.

In his eighth Boyle Lecture, Van Mildert defends the Albigenses and Waldenses. They were not merely "bodies of individuals separating from the Romish church because they could not conscientiously comply with its terms of communion."

They are to be vindicated, not only upon the general duty of separation from a church which imposes sinful terms of communion (much less upon the loose principles of modern schismatics, who hold every private congregation of Christians to be a church in itself), but upon the solid grounds of church authority, by which every national or provincial church, duly governed by bishops of apostolical origin, hath a right (taking the holy scriptures for its guide) to frame its own articles and its own ritual, independently of other churches ${ }^{2}$.

1 Theological Works, vol. I. pp. 290 foll., 298.

2 Ibid. vol. II. p. 238. 


\section{The English reformers in particular}

acted not against any lawful authority, but in complete subordination to it; the reformation in this country being carried on under the direction of the spiritual governors of the church, who were bishops as truly and apostolically constituted as any bishops upon earth ${ }^{1}$.

The leaders of the protestant reformation " did not intend anything subversive of the primitive constitution of the church." Generally speaking, they resisted the pope, "not in his episcopal character as Bishop of Rome, nor as metropolitan or patriarch in the province over which he might have lawfully presided,"' but as an usurper of spiritual and temporal authority to which he had no just claim.

Thus far we see nothing which can fairly be construed into an attempt to overthrow the Christian church, no infringement of its legitimate authority, no inclination to set aside the apostolical succession of its ministers, or to slight any one article of the true catholic faith. On the contrary, many of the warmest advocates for the reformation are well known to have manifested an unshaken attachment to episcopacy, as of divine ordinance, and jealously to have adhered to all the great fundamental doctrines of salvation. If these principles had been universally acted upon, vain indeed would have been the efforts of its bitterest enemies to fix a stain upon the reformation ${ }^{2}$.

1 Theological Works, vol. Ir. p. 242.

2 Ibid. p. 256 . It is interesting to see in the Appendix at the end of the volume, what writers Van Mildert chiefly appeals to in support of the statements and opinions above quoted. Laud, Leslie, Hickes, Overall, Hall, Morton, Waterland, these are among them, but Leslie and Hickes are the most frequently cited. 
The last of Van Mildert's Bampton Lectures is on the church and its discharge of the trust committed to it as the preserver of scripture truth. Van Mildert discusses the interpretation of the text about the "pillar and ground of the truth." He understands the church there to be " the church catholic, the visible church here on earth." But he comes still nearer :

Here however it is to be observed that in describing the church as so eminently instrumental to the preservation of scripture truth, and even of Christianity itself, it is spoken of as existing under that apostolical form of government which from the date of its first institution it has invariably exhibited in the far greater part of the Christian world. It is the church episcopally constituted ${ }^{\mathbf{1}}$, which forms our present subject of investigation; not any of those various modes of professing Christianity which may be found in communions of other kinds. For without entering into controversy with those who deny the divine origin of episcopacy, it can hardly be disputed that this form of ecclesiastical polity has so generally prevailed, that in every age from the time of the apostles until the separations which in some instances unhappily took place at the period of the protestant reformation, the catholic or universal church, properly so-called, comprising many particular or national churches, was known and distinguished by its episcopal constitution. Speaking therefore historically only,...we are warranted in thus defining the church; and the question now before us is, how far the church, thus defined, has hitherto proved itself to be the pillar and ground of the truth ${ }^{2}$.

1 The italics are Van Mildert's.

2 Theological Works, vol. IV. p. 223. 
He enumerates the essential doctrines of Christianity, and asks :

At what period of the church have these doctrines, or either [i.e. any] of them, been by any public act disowned or called in question? We are speaking now, it will be recollected, of what in the language of ecclesiastical history is emphatically called THE CHURCH; that which has from age to age borne rule, upon the ground of its pretensions to apostolical succession. And to this our enquiry is necessarily restricted ${ }^{1}$.

Van Mildert passes on to the church of England. Her " moderation," in Timothy Puller's sense of the word", appeals strongly to him. Faithful to the paramount authority of scripture, but insisting on "the necessity of resorting to the aids of human learning in fixing its interpretation," she testifies her deference to the judgment of the church catholic, when it can be duly obtained.

But notwithstanding this care to avoid error on her own part, and to discountenance it in others, no uncharitable invectives, no bitter anathemas, are fulminated against those who separate from her communion: nor is any unwillingness manifested to give the right hand of fellowship to any other churches with whom it is possible to hold lawful communion....Great, too, have been her concessions towards those who have stirred up dissensions among her members: concessions not made for the sake of popularity, or to enlarge her pale for the admission of them who are unsound in the faith, but that separatists might hereby be rendered more willing to listen to her instructions upon essential points, and to examine with candour the lesser matters on which such differences

1 Theological Works, vol. IV. p. 225.

2 Puller is one of his favourite authors. 
existed.... And hence she has been regarded, even by those not of her own communion, as the fit medium of reconciliation between other churches. It is well known, indeed, that some of her most distinguished members have expressly aimed at forming, upon the model of her constitution, some plan of union, which, without a sacrifice of fundamental principles, might unite foreign churches with our own, and bring contending parties to something like mutual agreement.

He sadly adds :

But the failure, hitherto, of every such attempt only serves to show the impracticability of the thing, and may teach us to be so much the less sanguine in our expectations that the purpose will ever be accomplished ${ }^{1}$.

Another of his sermons, on Christian unity, contains a grave warning against the fictitious union, at which "some novel schemes of latitudinarianism" seemed to be aiming, which would involve communion "with such as turn the sacraments into acts of idolatrous superstition, and with such as acknowledge neither sacraments nor priesthood."

Though we enlarge our views of Christianity to its utmost extent, though our charity be as expansive as the gospel itself, we cannot extend its benefits further than that sacred charter extends them.... We cannot take upon us to say that he who denies the divinity of the Redeemer, and he who acknowledges him as his Lord and his God, stand upon equal ground. We cannot instead of one body, one spirit, one hope, one Lord, one faith, and one baptism, acknowledge many bodies of diverse kinds, many discordant spirits, many hopes growing out of dissimilar persuasions, many different objects of worship, many conflicting articles of faith, many baptisms or modes of admission into the

1 Theological Works, vol. Iv. pp. 238 foll. 
Christian covenant; for this would be to annul the charter itself... The peace, indeed, of the whole community, of those who separate from the church as well as of those who adhere to it, mainly depends upon that singleness of heart, that honest simplícity of character and conduct, which never can be otherwise than respected, whatever be the shades of difference which separate parties from each other. It is not the mere semblance of unity, the attempt at a spurious coalition of sects or individuals, that can reasonably be expected to produce this effect. It is the honest and undisguised maintenance, on each side, of what each holds to be the truth, with Christian lenity and forbearance towards what each deems to be error in the other party, which must lay the foundation of peace and goodwill ${ }^{1}$.

The devout and accomplished Reginald Heber had no idea of being a bigoted partisan. In one of his amusing private letters he speaks of " offending one or both of the two fiercest and foolishest parties that ever divided a church,- - the high churchmen and the evangelicals ${ }^{2}$." He represented, or supposed himself to represent, the great body of English churchmen. In a paper written in I8I2 Heber contends for the validity of lay-baptism. It contains some interesting expressions:

- I know of no clergymen, except the Wesleys, who have refused the eucharist to persons who, having been baptized in a dissenting communion, have afterwards come over to the church.... The German Lutheran clergy are as absolutely without episcopal ordination, and therefore in the view of an episcopal church as merely laymen, as the dissenting teachers in our own country. Yet who ever maintained

1 Theological Works, vol. vi. pp. 471, 476.

2 Life of R. Heber, by his Widow, vol. Ir. p. 5 .

M. 
that King George I or the successive queens of this country were not members of the Christian church? Or who has blamed the venerable Societies for the Propagation of the Gospel and Promotion of Christian Knowledge for recognizing, not only the baptism, but the ordination of Lutheran superintendents and elders, and employing as missionaries and as dispensers of the sacrament those who, if your correspondent were correct, are not entitled to receive the eucharist themselves ${ }^{1}$ ?

\section{Writing to a Roman Catholic in I8I4, Heber says :}

I also, as well as you, believe in the holy catholic church. ... By the catholic church we mean that society of faithful people all over the world which is called by the name of Christ and governed, according to the appointment of the apostles, by bishops, priests, and deacons ${ }^{2}$.

\section{A remarkable letter of his is addressed (in I823)} to a chaplain in India who had refused to allow Heber's archdeacon to preach in his church. It reveals a very decided view of what the episcopal office means:

It is my duty to observe that the power of preaching, which the bishop himself possesses, he has a right to delegate to any person in holy orders whom he may think it expedient to employ. It is through him that in the first instance the commission is derived to preach at all, or to exercise any ministry in the church whatever. But a fortiori he who can elevate a layman to the rank of priest can authorize a priest to preach in any place where he is himself entitled to do so.... There is indeed one instance on record (but it is an instance which you will hardly accept as favourable to your cause) in which an Asiatic bishop complains of an arrogant presbyter who refused to receive into the church

1 Life of R. Heber, vol. I. p. 384.

2 Ibid. p. 409. 


\section{The Revolution and Since}

those who went forth to be fellow helpers of the truth... 1 . I do not, I cannot, forget the awful distance between his [Diotrephes'] offence, who resisted an inspired apostle, and his error who questions the right of a short-sighted and sinful person, his fellow-transgressor.... But though the worthiness of the person differs, and though the spiritual gifts have been withdrawn, the commission from Christ is still, as I apprehend, the same ; and it is the official capacity of a bishop which... entitles his regulations to the respect and obedience of his clergy.

The chaplain had apparently objected that a bishop in India had not the same rights and powers as a bishop in England. Heber replies:

A bishop, as such, is not the creature of the civil magistrate. His authority existed before the civil power had recognised him.... And whether it is found in a state of depression and discountenance, as in the episcopal church of Scotland, or in a state of persecution, as in the episcopal church of Greece, or altogether unconnected with the civil institutions of the land, as in the episcopal churches of North America and Malayalim, it admits no other, and it can seek no nobler, source of authority than that of "As my Father hath sent me, so send I you.". ... I am very far indeed from judging those who, from conscientious error, reject the form of episcopal government. To one [? our] common Master they must stand or fall ; and my best desire and my daily prayer to God is that they as well as we may be found standing on the same divine book before him. But I am addressing the avowed member of an episcopal church, who has received his commission to preach from episcopal hands, and whose very continuance in the communion and service of that church is a tacit engagement to submit to episcopal authority ${ }^{2}$.

1 III John 8 foll.

${ }^{2}$ Life of $R$. Heber, vol. II. pp. I60-163. 
Much has been made of the fact that the English missionary societies employed at that time missionaries who, in the language of Heber before he went to India, were " mere laymen." A letter of his in I825 to the S.P.C.K. shows-what perhaps has not been sufficiently observed-that this employment was not unrestricted, and that the anomaly was felt:

I trust I am not illiberal in expressing a hope that the society will supply us with episcopally ordained clergymen. Englishmen by nation, as well as in church discipline, are on many weighty accounts to be preferred. But if these are not forthcoming, I would earnestly recommend a recourse to the ancient and apostolic churches of Denmark and Sweden, from whose universities...there would be no difficulty in obtaining learned and meritorious candidates.... With the individual missionaries of the Lutheran church now in the employ of the society I am far, very far indeed, from having any reason to be dissatisfied.... Still, there is a difference between them and us in matters of discipline and external forms, which often meets the eye of the natives, and produces an unfavourable effect upon them. They are perplexed what character to assign to ministers of the gospel, whom we support and send forth to them, while we do not admit them into our own churches. And so much of the influence and authority which the church of England is gradually acquiring with the Christians of different oriental stocks (the Greeks, Armenians, and Syrians) arises from our recognition of, and adherence to, the apostolic institution of episcopacy, that it is greatly to be desired that all who are brought forward under our auspices in these countries should in this respect agree with us.

A strong perception of these inconveniences has induced three of the Lutheran missionaries employed in Bengal by the Church Missionary Society, with the approbation of 


\section{The Revolution and Since}

that body, and in a considerable degree influenced by my opinion, to apply to me for re-ordination according to the rites of the church of England; and I had much satisfaction in admitting them to deacon's orders on the last St Andrew's day; and though I am far from urging any of those already engaged with us to contract...this closer union, and though I trust I shall not be suspected of showing any unkindness or distance towards those who are content with the species of commission which they have already received, I hope that in their choice of future labourers the Society will not disregard the suggestion which I have ventured to offer ${ }^{1}$.

The firmness of Bishop Heber's convictions on the subject may be seen in the letter which he wrote to the missionaries of the Church Missionary Society at Cotta, who had consulted him about the propriety of their holding conferences with " missionaries of other religious sects" on topics connected with their work among the heathen. Heber warmly approved of the spirit manifested on both sides in this practice, and encouraged the churchmen to go forward with it, while mentioning certain cautions to be observed. The first danger to which these meetings, he said, were liable,

is the risk of levelling, in the eyes of others, and even in your own, the peculiar claims to attention on the part of men, and the peculiar hopes of grace and blessing from the Most High, which, as we believe, are possessed by the holders of an apostolic commission over those whose call to the ministry is less regular, though their labours are no less sincere. God forbid, my brethren, that I should teach you to think on this account highly of yourselves. Far

1 Life of R. Heber, vol. II. pp. 348 foll. Cf. the account of his reordination of Abdul Musseeh on p. 363. 
otherwise. This sense of the advantages which we enjoy should humble us to the dust, when we bethink us who we are, and what we ought to be, who have reccived the Spirit of God by the dispensation of a long line of saints and martyrs,... and who are by the external dispensation, at least, of providence the inheritors of that grace which fell on St Paul. But humbly, yea meanly, as we are bound to think of ourselves, we must not appear to undervalue our apostolic bond of union; and the more so here in India, inasmuch as it is the great link which binds us to the ancient Syrian church [in the midst of which Cotta was placed], and one principal means whereby we hope, with the blessing of our Master, to effect its gradual reformation ${ }^{\mathbf{1}}$.

From across St George's channel comes a voice in the latter half of the I8th century which sometimes reminds us of the days of Bramhall and of Taylor. It is that of Philip Skelton. Presumably towards the close of his life-he died in I787--Skelton delivered a discourse, which he calls "a free and open expostulation with the dissenters," entitled, The Church of Christ can have but one mind. In the course of it he observes

Among all the transactions of the church from the apostolic age down to this, I know of none managed with more temper, more tenderness, more regard to scripture or primitive practice, as delivered to us by written (not pretended, oral) tradition, than the reformation of the church of England ${ }^{2}$.

He describes the great features of this work, and then how it was marred by the puritans.

1 Heber's Indian Journal, vol. II. p. I55 (ed. 1844).

2 Works (ed. I 824), vol. III. p. 357. 
The next thing the puritans took offence at was the hierarchy of the church. They looked on the bishops as the instruments of papal tyranny and the corrupters of true religion. They were therefore of Machiavel's mind, who said, if that monk (meaning Luther) does not cut the very core out of this boil, namely episcopacy, it will grow again, and render vain all he hath done. They, as if taught by this master, were, it seems, so ignorant as not to know that the bishops, of all men. had most reason to oppose the usurpation of the bishop of Rome, who had made himself the only bishop, and reduced all the rest to cyphers. Nor did they consider whether it was in the power of man to abolish at his discretion an order of the church, instituted by God himself, merely because the men who filled this order had degenerated, together with all the rest of the church, into superstition and luxury.

Here again the scheme of our opposers was not to reform, but to destroy; and what was equally bold, to begin a new ministry, with hardly any other mission than such as a number of men, and sometimes one man only, wholly unauthorized, for aught that others could perceive, should assume. From men thus sending themselves, or sent by we know not whom, we are to receive the sacraments. And what is marvellous beyond all conception, this new species of ordination, though apparently [i.e. evidently] of human institution, is now become too sacred to be interrupted, while that which seems at least to be of Christ, is laid aside.

But why, in the name of wonder, may we not as well have a new mission every day? Hath the church, or rather the multitude, lost its faculty, so prolific two hundred years ago, in the equivocal generation of missions? We must not forget, however, that these new orders lay claim to scriptural institution and primitive example. What, all of them ? And without succession? Do we hear of any man in scripture who ordained himself, or who presumed to take the ministry of God's word and sacraments upon him without being sent either immediately or successively by 
Christ? Or can an instance of this nature be assigned during the first fourteen centuries of the church ? Or will even those protestants, who adopted a new mission at the reformation, now suffer anyone to administer the sacraments among them without ordination, obtained in succession from that adoption? Do they not by this strictness practically confess at least the expediency of such a succession? But if a succession of this nature may be warrantably founded on their invention, why not on Christ's institution'.

\section{Skelton turns to the plea of an extraordinary mission :}

Perhaps however they who gave rise to a new current of ordination were immediately authorized so to do by divine inspiration. This, I believe, will hardly be now insisted on. But if it is, and supernatural inspiration proved, even that will not serve this turn. So sacred a thing is the succession of ordination, that the Holy Ghost, who had already enabled Barnabas and Saul to preach the word, ordered them to be separated for the work whereunto he had called them, by fasting, prayer, and imposition of hands, that is, to be ordained; the Spirit of God hereby plainly showing that he himself would not break the successive order of mission established in the church. Without in the least regarding this, or other passages of scripture, that plainly point out the three orders, the reformers I am speaking of, though strenuously insisting on scripture as the only rule of reformation, threw out the episcopal order, and began a new method of authorizing orders, until that time unheard of in the church ${ }^{2}$.

Skelton ends with an appeal to the dissenters to consider...whether we differ about anything of real moment (I speak to you only who agree with us in fundamentals) excepting the single point of church government;

1 Works, vol. III. pp. 360 foll.

${ }^{2}$ Ibid. p. 36r. 
whetherChrist himself did not govern the church episcopally ; whether he gave us any reason to think he intended this method of government should be altered on his leaving the world; whether he did not rather entail it on the church by sending his apostles as his Father had sent him; whether Timothy and Titus were not constituted real bishops, with authority over presbyters and deacons, by St Paul... whether what [that holy martyr, St Ignatius] delineates in this behalf is not evidently traced in the practice of all churches down to the reformation; whether at that period many reformers...did not proceed rather by pique and prejudice, than by reason or authority, scriptural or traditional, in rejecting the episcopal order... whether the merits, as to this, can ever be decided by our preconceptions of either side...or in short by any other method than that of a cool dispassionate appeal to scriptural authority, explained by the practice of antiquity. After having maturely weighed these things, we beg of you then seriously to consider in the last place, whether any set of Christians can warrantably lay aside the succession of orders, so plainly founded by Christ himself, and so long religiously kept up by all his church, and begin a new succession, without even the colour of necessity ${ }^{1}$.

It is much to be wished that this powerful appeal were better known than it is.

For the sole reason that a name so clarum et venerabile may not be passed over, let a few words of the great lay theologian of the church of Ireland be added to those of Skelton. Writing in I8I2 "on the central character of the church of England," Alexander Knox says that the liturgy is the golden chain, or rather " that silver cord (for so Solomon calls the spinal marrow) which unites us to the great

1 Works, vol. III. pp. 373 foll. 
mystical body." Other things, like the XXXIX articles, providentially help to equip us in view of " the conciliatory function to be one day exercised by us."

But our vitality as a church consists in our identity of organisation and of mental character with the church catholic: and as our unbroken episcopacy implies the first, our liturgy, and that alone (because an actual effluence of "the catholic religion") contains the other ${ }^{1}$.

The old school of Anglicans found one of its noblest representatives in the early part of the Igth century in the person of the famous Bishop of Limerick, John Jebb.

An ordination sermon of his, preached in I8Io, sets forth in no uncertain tones, not only the doctrine of the apostolical succession of the ministry (which is assumed, rather than asserted), but also the catholicism which uses the teaching of the past for the guidance of the future. It is on the last words of St Matthew's Gospel.

It was the last act of our Lord's earthly ministry, the preacher begins, to deliver his instructions, and delegate his authority, to the holy apostles; and through the apostles to their legitimate successors in all ages of the church ${ }^{2}$.

To " disciple all nations" means

Receive whole communities into the outward, visible profession of Christianity. Make collective bodies of disciples, whom you may afterwards instruct. Let nations be united in the common bond of catholicity. And let them transmit from generation to generation the means of religious worship, and the light of religious truth ${ }^{3}$.

1 Remains, vol. III. p. 69.

? Practical Theology, vol. I. p. II 7 .

3 Ibid. p. I2I. 
The promise, "Lo, I am with you alway," is

not occasional or temporary, like that of miraculous powers, but conveying an assurance that Christ himself will in spirit and in power be continually present with his catholic and apostolic church; with the bishops of that church, who derive from the apostles by uninterrupted succession; and with those inferior, but essential, orders of the church, which are constituted by the same authority, and dedicated to the same service ${ }^{1}$.

Jebb dwells in an instructive manner on the passage in the epistle to the Ephesians where St Paul speaks of superhuman intelligences as learning from the study of the developing history of the church.

The church, then, be it specially observed, is not a simple accumulation of individuals ; but it is, what holy scripture declares it to be, a regulated society, an organized body; preserving through successive ages its identity of essence and unity of spirit ; receiving from time to time a continual increment of members, and through the instrumentality of those members deriving growth, and strength, and gradual advancement towards that complete maturity, when it shall attain unto the measure of the stature of the fulness of Christ $^{2}$.

Sketching in bold outlines the course of Christian history, Jebb comes to " the glorious reformation."

Of this reformation, he says, the fairest portion is, by the blessing of God, our providential birthright. And in this place, and on this occasion, I cannot forgo the gratification of paying an humble tribute of duty and affection to our venerable parent, the church of England. The pious founders of our national establishment ${ }^{3}$ both deeply

1 Practical Theology, vol. I. p. I22.

2 Ibid. p. 126.

3 He does not mean the church of England itself by this expression, but the system under which it now exists. 
pondered, and sincerely loved, a principle which in literature, in politics, in morals and religion, is far above all price, and which should be engraven on the hearts and consciences of all Christian philosophers, statesmen, and divines; the principle, namely, that to innovate is not to reform.... Adorers of God's special providence, they could not consign to oblivion, as superfluous and superannuated, those documents of most remote antiquity, that "precious life blood of so many master-spirits," which amidst the resolutions of ages had been providentially " embalmed and treasured up, on purpose to a life beyond life ${ }^{1}$." They felt that as the universal consent of all men in all ages is allowed to be the voice of nature, so the unanimous concurrence of councils, churches, bishops, and fathers, ought to be received as the voice of the gospel. Therefore, when they came to reform abuses, they adopted as their motto and their principle that golden decision of the council of Nice, "Let ancient usages prevail."

Such was the spirit in which our reformers executed their holy work; and we enjoy the fruits of their labours,an uninterrupted succession from the apostolic age of bishops, priests, and deacons, not pensioners on the state, not dependants on the people...a body of liturgical services, the collected and concentrated spirit of whatever was most valuable in all Christian antiquity....an exposition of national faith, which, to be rightly apprehended and duly appreciated, must be carefully collated with the sacred scriptures, with the general voice of Christian antiquity, and with the confessions of other reformed communities. On such a comparison, it may be safely affirmed...that the articles of the church of England are more accurate and less rigid, more liberal and less relaxed, more orthodox and less dogmatic, than those of any other society at present in existence. And the reason is plain : our reformers were not desirous, either literally to coincide

1 A quotation from Milton's Liberty of unlicensed Printing. 


\section{The Revolution and Since}

with, or unlimitedly to dissent from, any particular communion, whether that of Geneva, of Augsburg, or of Rome. For it can be established by a cloud of witnesses that the sacred scripture was their test, and the harmony of all churches in all ages their great expositor ${ }^{1}$.

The week before the battle of Waterloo, Jebb dedicated to the archbishop of his province a volume of sermons containing an appendix " relating to the character of the church of England as distinguished both from other branches of the reformation and from the modern church of Rome." He was indebted for help in composing it to Alexander Knox. It is an essay which deserves to be better known than it now is.

At the present day, Jebb writes, it is by no means sufficiently considered that the church of England occupies a very peculiar station in the Christian world; constituting, as it were, a species in herself.

Her specific temperament, indeed, has during the last century been most inadequately recognised at home. But it has not failed to attract the notice of foreign observers. The sagacious Mosheim, for example, and he is not singular in his statement, describes the English church as that correction of the old religion which separates the Britons, equally, from the Roman Catholics, and from the other communities who have renounced the domination of the pope $^{2}$.

To illustrate " the difference between the English church and the great protestant body," and also " the agreement between the English church and the

1 Practical Theology, vól. I. pp. I35-138.

2 Sermons on Subjects chiefly practical (ed. 1832), p. 365. 


\section{The Revolution and Since}

catholic apostolical church of ancient times," the bishop quotes "the memorable Protest" of I529, from which Protestantism takes its name-in which protest it is questioned where the true church is to be found, and maintained that the bible is only to be interpreted by the bible, without restriction or qualification.

The different course pursued by the English church is apparent at first view ; and the contrast will gain strength the more closely it is examined. The church of England, for example, does not affect to doubt where the true church is to be found. Without pronouncing censures on those instances of ecclesiastical irregularity, which God has seen good to permit, and which he may therefore be graciously pleased to excuse, the English church expresses her idea of that " one body," of which the Christian church regularly consists, by her own uncompromising adherence to derivative episcopacy, and by her rejection of all clerical orders which have not emanated from that source. Assured, therefore, of the quarter in which the fulfilment of our Saviour's promise, "Lo, I am with you always"... is to be looked for, she directs her children, and still more her ministers, instead of relying on their own interpretation of the sacred word, to consult the concurrent lights of antiquity. ...Thus it is evident that the church, in the strictly catholic and hierarchical sense of the term, is on the one side recognised and revered; while on the other side not only her guidance is rejected, but her existence is disputed ${ }^{1}$.

The bishop then quotes the Vincentian rule of catholicism, and shows in several ways how much more closely the English church conforms to it than the modern Roman church.

1 Sermons on Subjects chiefly practical, p. 370. 


\section{The Revolution and Since}

But where at this day are those views retained, except in the church of England ? The protestant communions on the continent have not so much as pretended to revere antiquity.... The church of England alone has adopted a middle course: moving in the same delightful path, and treading in the same hallowed footsteps, with Vincentius and the catholic bishops and the ancient fathers; proceeding as far as they proceeded, and stopping where they stopped ${ }^{1}$.

Jebb examines the language of the collects in regard to the church :

These and similar expressions, confined as they are, both in their own original import and by the most authoritative declarations, to the strictly hierarchical church, as a visible and incorporated polity, imply by inevitable consequence that it is the interest, no less than the duty, of each individual Christian to adhere to the fellowship, to study the movements, and with all possible diligence to trace the very footsteps, of this heaven-directed society, in order that he may walk in its light, gain instruction from its movements, and derive animation from its influence ${ }^{2}$.

He specially singles out the prayer "for all sorts and conditions of men " for praise :

This noble devotional composition, primitive in its spirit, though modern in its date, implores that "good estate of the catholic church," in which all wandering sheep shall be brought back to the one fold, and walking in the way of truth, as partners of the same faith, shall not only endeavour after, but attain and enjoy, the unity of the spirit, in the bond of peace. Now, as there is but one way of truth, there can be only one unity of spirit; a blessed

1 Sermons on Subjects chiefly practical, p. 386.

${ }^{2}$ Ibid. p. 388. 


\section{8 \\ The Revolution and Since}

unity of mind and heart with the whole catholic church,not merely with existing communities of Christians, but with that countless multitude which has passed on before. For in truth this retrospective unity with the church of old is the only solid ground for present unity with contemporaries, and for prospective unity with the church progressive upon earth and consummated in heaven. A clear and definite principle of union is indispensable; and such a principle cannot either be discovered or conceived, except in the "following of those who through faith and patience have inherited the promises ${ }^{1}$."

1 Sermons on Subjects chiefly practical, p. $3^{89}$. 


\section{CHAPTER VI}

\section{MODERN ANGLICAN CRITICISM}

IT is unnecessary to trace in detail the history of Anglican opinion on the historic episcopate beyond the date which has now been reached. Bishop Jebb died in the year of Keble's assize sermon, from which the tractarian revival starts. Enough has been said to show that a belief in the divine institution of episcopacy was no invention of the Oxford movement, and no mediaeval theory dug up out of a forgotten past. It was the living tradition of the English church all through the I8th century and even in the first quarter of the rgth. The most: powerful defenders of the doctrine after the Oxford movement had begun were men who had formed their convictions earlier. Henry Phillpotts, Bishop of Exeter, was such a man ; and he had many others with him. There was nothing new in the tractarian insistence upon the apostolical succession. What was to a certain extent new was on the one hand the rigid aloofness with which the tractarians regarded the foreign churches which were without it, and on the other hand the passionate scorn with which the doctrine was repudiated by partisans of the opposing school. Of these two novelties the second, if the 
expression may be allowed, was the newer. Men like Bishop Croft had thought that the doctrine was unduly pressed. Men like Hoadly and the younger Gilbert Burnet could sneer at it, because they sneered at all that was characteristically Christian ; but they knew that they were opposing the doctrine of their church. Men like Warburton, Paley, and Hey, could write of it with critical detachment. Men outside the pale or barely within it, like Baxter, might deny it. But the church of England had seen nothing from the hands of her own sons like the diatribes of William Goode and his associates against the reassertion of what had been taught by all the great Anglican divines from Jewel to Jebb.

That there was much that was irritating and onesided in the writings of some of the tractarians is true; but the new attitude which they took up towards foreign protestantism in general was not altogether unjustified. Earlier English theologians had almost always based their defence of foreign orders upon two grounds. One was the ground of necessity ; they assumed that the foreign reformers could not help resorting to uncatholic methods of ordaining. The other was that the foreign reformers stood (with whatever qualification in particulars) for what was catholic and primitive, as against the modern corruptions of Rome. Both grounds began to fail under the defenders' feet. The misgivings of the Laudian and Restoration writers with regard to the plea of necessity proved to be only too well founded. History made it clear that many of the foreign reformers, 
particularly the Scottish, broke with episcopacy on purpose. And the process of doctrinal disintegration had begun to set in. Things had not gone as far in that direction in 1833 as they have gone in $\mathrm{IgI}_{4}{ }^{1}$; but, in spite of Pusey's early defence of German theology, there was reason for the fears of Hugh James Rose and others. It could no longer be said with truth that foreign protestantism represented the protestantism of a Chillingworth, still less that of a Cosin. To a large extent it was already not only anti-Roman, but anti-Catholic. Their cause was only in a small measure ours.

Meanwhile, partly under the stimulus of continental research, the origin of Christian institutions began to be studied by new methods and in a more disinterested spirit than at an earlier time. Before Dr Pusey died two works had been produced by Anglican theologians, one at Oxford and one at Cambridge, dealing with the subject of episcopacy from a wholly different standing-point from that of the Froudes and the Percivals or the Goodes either. The two works were the Bampton Lectures of Edwin Hatch in 1880, on the Organization of the Early Christian Churches, and the dissertation on The Christian Ministry appended by Joseph Barber Lightfoot to his edition of the Epistle to the Philippians in $\mathrm{I} 868$.

1 Professor Loofs has recently said that he does not know a single learned man in Germany who holds the belief in the person of our Lord which is defined in the decrees of the four great ecumenical councils. 
Some apology is necessary for mentioning the two works in a single sentence. The reason is that controversialists have spoken of them together, as together making it impossible, on critical and historical grounds, to maintain the doctrine of the apostolical succession as it was taught (let us say) by Pearson, or the fact that episcopacy is of apostolic and therefore of divine institution. It was pointed out by the " Principal of a Theological College," in a series of letters to the Times a few years ago, in answer to one such controversialist, that it was impossible to teach the views of Hatch and Lightfoot to theological students as if they were a single whole: it was necessary to choose between them. The caution is not yet superfluous. The two names still sometimes appear together in the effusions of men who should know better. It will be no unfitting conclusion to this enquiry to say a few words on both the works.

Hatch's Bampton Lectures were not at all written with a polemical purpose,-at any rate with no destructive or anti-ecclesiastical intention. They form a singularly lucid and able attempt to explain some phenomena of early church history, which had long been known, by the light of facts accumulated in other departments of knowledge, especially in the department of epigraphy. The formation of the catholic church did not seem to Hatch to be any less divine and predestined because he thought that it could be accounted for on purely natural principles. 


\section{Modern Anglican Criticism}

If the evidence shows, as I believe it to show, that not only did the elements of the Christian societies exist, but that also the forces which welded them together and gave them shape are adequately explained by existing forces of human society, the argument from analogy becomes so strong that, in the absence of positive proof to the contrary, it is impossible to resist the inference that in the divine economy which governs human life, as it governs the courses of the stars, by the fewest causes and the simplest means, the Christian societies, and the confederation of those societies which we commonly speak of in a single phrase as " the visible church of Christ," were formed without any special interposition of that mysterious and extraordinary action of the divine volition, which for want of a better term we speak of as "supernatural1"."

He recalls how according to modern scientific doctrine man's life was evolved out of lower organic forms, without being the less divine :

And so it may be... out of antecedent and, if you will, lower forms, out of existing elements of human institutions, by the action of existing forces of human society, swayed as you will by the breathing of the divine breath, controlled as you will by the providence which holds in its hand the wayward wills of men,... came into being that widest and strongest and most enduring of institutions which bears the sacred name of the Holy Catholic Church. The divinity which clings to it is the divinity of order ${ }^{2}$.

There is nothing derogatory to the church in this teaching. It is compatible with the loftiest conceptions of the Christian ministry. The question is whether it is compatible with all the facts of history, or only with a selection of them.

\footnotetext{
1 Organization of the Early Christian Churches, p. is.

2 Ibid. p. 20.
} 


\section{Modern Anglican Criticism}

Hatch's theory is this. He takes his start with the Christians among the Gentiles. He shows how the principle of association was everywhere at work at the beginning of the Christian era. The Roman empire was covered with associations innumerable, for every imaginable purpose. These associations almost all contained a religious element.

When the truths of Christianity were first preached, especially in the larger towns of the Roman empire, the aggregation of those who accepted those truths into societies was thus not an isolated phenomenon ${ }^{1}$.

Hatch implies that the principle of association was not an original and inherent and necessary part of the gospel.

Such an aggregation does not appear to have invariably followed belief. There were many who stood apart; and there were many reasons for their doing so.... The union of believers in associations had to be preached, if not as an article of the Christian faith, at least as an element of Christian practice ${ }^{2}$.

Of exhortations to this effect he quotes several early examples.

After the sub-apostolic age these exhortations cease. The tendency to association had become a fixed habit. The Christian communities multiplied, and persecution forged for them a stronger bond of unity. But to the eye of the outside observer they were in the same category as the associations which already existed ${ }^{3}$.

The prime factor in the Christian associations was, according to Hatch's theory, an economic one.

1 Urganization of the Early Christian Churches, p. 29.

2 Ibid.

3 Ibid. p. 30. 


\section{Modern Anglican Criticism}

They were in the first instance benefit societies, consisting for the most part of very poor people. The obligation of the well-to-do to help their needier brethren was their chief obligation.

It was in this point that the Christian communities were unlike the other associations which surrounded them. Other associations were charitable: but whereas in them charity was an accident, in the Christian associations it was of the essence. They gave to the religious revival which almost always accompanies a period of social strain the special direction of philanthropy ${ }^{1}$.

Now in the contemporary non-Christian associations of Asia Minor and Syria

the officers of administration and finance were chiefly known by one or other of two names, not far distant from one another in either form or meaning. The one of these was $\dot{\epsilon} \pi \iota \mu \lambda \eta \eta \eta^{\prime}$ s,...the other was the name which became so strongly impressed on the officers of the Christian societies as to have held its place until modern times,... the Greek imi

Thus the first "bishops" of the Christian communities were the financial administrators, who received the offerings of the members and distributed them, after solemnly dedicating them to God and uttering over them, in the name of the assembly, words of thanksgiving and benediction.

When the president became a single permanent officer, he was, as before, the person into whose hands the offerings were committed and who was primarily responsible for their distribution. He thus became the centre round whom the

1 Organization of the Early Christian Churches, p. 3.5 .

2 Ibid. pp. 36 foll. 
vast system of Christian charity revolved. His functions as supreme almoner tended to overshadow his functions as president of the council... The title which clung to him was that which was relative to his administration of the funds,

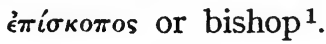

When he comes to describe the process which evolved the single "bishop" out of the committee of "bishops," Hatch affirms that there was an almost, if not altogether, universal tendency that way among contemporary organizations, and that there were various causes specially at work in the Christian communities which told in the same direction. Among these causes

there were some cases in which an apostle had been supreme during his lifetime, and in which the tradition of personal supremacy lingered after his death. There were others in which the oversight of a community had been specially entrusted by an apostle to some one officer. There were others in which special powers or special merits gave to some one man a predominant influence. Rome, Antioch, Ephesus, are examples of such cases. It is, indeed, wholly uncertain how far they are typical: and there is a probability that, where such supremacy existed, it was personal rather than official, inasmuch as those who exercised it do not appear to have had, as such, any distinguishing appellation $^{2}$.

\section{A second cause was that}

there is clear proof of the existence of a theory of the nature of ecclesiastical organization which, from the fact of its persistent survival after a counter-theory had taken its place, may be supposed to have had a strong

1 Organization of the Early Christian Churches, p. 4I.

2 Ibid. p. 86. 


\section{Modern Anglican Criticism}

hold upon the communities among which it existed. To the writer of the Ignatian epistles ${ }^{1}$ each organized community of Christians is a perfect reflex of the whole church of God.... The bishop sat in the Lord's place; the presbyters were what the apostles had been: it was for the rest of the community to listen and to obey.... The theory seems to go back to the very beginnings of the Christian societies ${ }^{2}$.

\section{These facts, Hatch thought,}

seem adequate to account for the fact that the Christian communities were borne along with the general drift of contemporary organizations, and that the council of presbyters had a permanent president.... They are all compatible with the view that the early bishop stood to his presbyters in the relation of...the chairman to the ordinary members of a committee. They do not account for the fact that the bishops of the third and subsequent centuries claimed for themselves exceptional powers, and that the relation of primacy ultimately changed into a relation of supremacy ${ }^{3}$.

This development is traced as follows. When Gnosticism arose, the problem pressed for an answer, what should be the basis of Christian union. It was a great crisis.

But great crises give birth to great conceptions. There is a kind of unconscious logic in the minds of masses of men, when great questions are abroad, which some one thinker throws into form. The form which the "common sense," so to speak, of Christendom took upon this great question is one which is so familiar to us that we find it difficult to go back to a time when it was not yet in being.

1 Hatch wrote before Lightfoot had proved to demonstration that the writer of the Ignatian epistles was Ignatius.

${ }^{2}$ Organization of the Early Christian Churches, pp. 87 foll.

3 Ibid. pp. 89 foll. 
Its first elaboration and setting forth was due to one man's genius. With great rhetorical force and dialectical subtlety, Irenaeus...maintained that the standard of Christian teaching was the teaching of the churches which the apostles had founded, which teaching he held to be on all essential points the same... To that fides catholica et apostolica all individual opinions and interpretations were to be referred ${ }^{\mathbf{1}}$.

In this view, Hatch affirms, which was already in the air, the Christian world gradually acquiesced. The Christian communities were saved from disintegration. But in the consequent up-building of a catholic and apostolic church arose the further question, how the teaching of the churches was to be known, and who were its conservators. In the rabbinical schools there was a succession of rabbis who handed on the sacred deposit of truth :

It might reasonably be supposed that in the Christian churches there had been a similar tradition from one generation of officers to another: that, in other words, the apostles had definitely taught those whom they had appointed, or recognized, as officers, and what had been so taught had been preserved by those who had succeeded those officers.... In the Clementines, for the first time, the president of the community is regarded in the light of the custodian of the rule of faith-in express distinction from the presbyters, who are entrusted only with that which is relative to their main functions, the teaching of the maxims of Christian morality. The point was not at once universally conceded; but in the course of the third century it seems to have won its way to general recognition. The supremacy of the bishop and unity of doctrine were conceived as going hand in hand: the bishop was conceived as having what Irenaeus calls the charisma veritatis; the

1 Organization of the Early Christian Churches, p. 93. 


\section{Modern Anglican Criticism}

bishop's seat was conceived as being, what St Augustine calls it, the cathedra unitatis; and round the episcopal office revolved the whole vast system, not only of Christian administration and Christian organization, but also of Christian doctrine ${ }^{1}$.

\section{In this way Hatch thinks}

that adequate causes have been found not only for the existence of a president, but also for his supremacy without resorting to what is not a known fact, but only a counterhypothesis-the hypothesis of a special institution. The episcopate grew, by the force of circumstances, in the order of providence, to satisfy a felt need. It is pertinent to add that this view... has not the merit or demerit of novelty... St Jerome...maintains that the churches were originally governed by a plurality of presbyters, but that in course of time one was elected to preside over the rest, as a remedy against division ${ }^{2}$.

Hatch adds that the supremacy of the bishop was consolidated by the necessity for unity of discipline, especially in dealing with those who had fallen or faltered under persecution. The " counter-theory" above referred to, which Hatch considers to have superseded the Ignatian, is this. In the Ignatian conception, the bishop represents the invisible Christ; the presbyters represent the apostles. But gradually it came to be thought that the bishop, not the presbyters, represented the apostles, and represented them in the sense of succeeding to their office and powers.

It was a still later development of this view to maintain that the bishops had also succeeded to the power of the

1 Organization of the Early Christian Churches, pp. 97 foll.

${ }^{2}$ Ibid. p. 98. 
apostles in the conferring of spiritual gifts, and that through them, and through them exclusively, did it please the Holy Spirit to enter into the souls either of individual Christians in baptism, or of church officers at ordination. This latest development... passed at length into the ordinals; and it still survives ${ }^{\mathbf{1}}$.

It does not seem necessary here to describe at length Hatch's account of the rise of the presbyterate. The government of elders among the Jews was well established: the system travelled with them wherever they went. It was an obvious thing to do, when elders appeared as officers in Jewish Christian communities. Hatch is not quite so clear as usual when he attempts to account for the appearance of elders in the Gentile churches. But he says that the system of local government by councils or committees was very widely spread; and that respect for seniority was very strong, and that the term "elders" appears in some instances to have been applied to the members of local Gentile councils. In this way he thinks it probable that the presbyterate in the Gentile churches " had a spontaneous and independent origin,"-more probable than "the direct transference of the Jewish office to the Gentile communities." This, he thinks, would account for the fact that the members of the governing council were known by various names: presumably he means the name of bishops, as well as that of presbyters $^{2}$.

1 Organization of the Early Christian Churches, pp. 106 foll.

2 Ibid. p. 65. 


\section{Modern Anglican Criticism}

Hatch's taking book had the singular honour of securing the approbation of Harnack himself. Harnack translated it into German, and published it with additional notes of his own. But Harnack's adhesion to the views of Hatch was somewhat transient. His latest work relating to the subject, The Constitution and Law of the Church in the first two Centuries (English translation I9Io), contains few traces of the influence of Hatch. Its main principles are quite different from those on which Hatch's work is based. Hatch has found few disciples besides. Meritorious as his work is in many respects, it cannot stand as a complete account of the development of the early church and its officers.

Only a few criticisms upon it can be offered here. At the very outset, Hatch begins at the wrong end when he takes the local associations or communities as his point of departure. All recent investigation points to the belief that the general community of Christians throughout the world, is prior to the formation of local associations. Men did not, as Hatch assumes, form local churches, and then transfer the name of church to the aggregate composed of them: it was precisely the other way. The work of Rudolf Sohm, in great measure now adopted by Harnack, shows that the conception of the ecclesia at large comes first, and that the local organizations are only so many manifestations or representative gatherings of the universal ecclesia. Hort's study of the Christian Ecclesia leads to a similar result. He is emphatic in asserting that the constituent elements 
of the one ecclesia are not the many ecclesiae, but the souls who are gathered in them. These great scholars are agreed that the title of the ecclesia implies no lower claim than that of being the new and true Israel, the people of God.

This being so, it cannot be considered true that the joining of believers in " associations " arose from the imitation of a system of associations already in existence. The existing associations very naturally aided the work of forming churches; but the idea of the union of believers lay in the preaching of the gospel itself. It was no spontaneous after-thought. And Hatch has laid far too great a stress upon the economic side of the Christian associations. Important as the economic side is, the associations were based upon something more vitally religious. Corpus sumus de conscientia religionis. Converts were not baptized into a benefit society, but into the body of Christ. What they met for was not primarily to pay in a contribution or receive a dole; they met to worship and to receive or impart spiritual edification. It is a curious and interesting accident that the officers of certain heathen societies who had charge

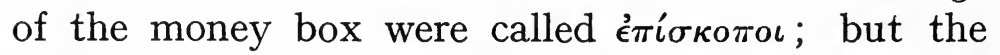
word was a very common one.

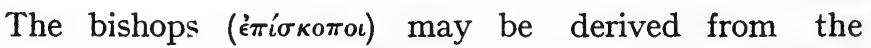
Septuagint ; they may have been copied from the municipal administrations; but they may also-and this is the most probable view-have arisen spontaneously. The word always signifies an overseer, curator, superintendent; but as to what the supervision is concerned with, it contains 


\section{Modern Anglican Criticism}

no indication. It may be souls; and then the word is equivalent to pastors;...but it may also be buildings, economic affairs, etc.; or it may be a combination of the two ${ }^{1}$.

In order to account for the evolution of the monarchical " bishop" Hatch is obliged to fall back, in part at any rate, upon an apostolical practice, and upon the existence of a theory of ecclesiastical organization. It will be felt how forced and artificial is the contrast which he draws between the Ignatian " theory " of the bishop's office and that of Irenaeus. If anything, the earlier image is the loftier. It seems a greater thing to be the representative of the invisible God than to be the successor of all the apostles put together;-and there is not the least conflict between the two conceptions.

Lightfoot's famous dissertation, written twelve years earlier, proceeds on very different principles. It is no attempt to extract a theory from new material, only remotely connected with the Christian documents. It is a sober, painstaking re-examination of the documents themselves, conducted in the spirit of the true historian.

It begins indeed with a doctrinal statement. The Christian church has no sacerdotal system. But the statement is followed immediately by a " necessary qualification." Lightfoot does not pause to argue the question whether the church is and always has been a corporate society: he assumes that it is so.

1 Harnack, Constitution and Law of the Church, p. 58. 
It must be evident that no society of men could hold together without officers, without rules, without institutions of any kind; and the church of Christ is not exempt from this universal law.... The church could not fulfil the purposes for which she exists without rulers and teachers, without a ministry of reconciliation, in short, without an order of men who may in some sense be designated a priesthood ${ }^{\mathbf{1}}$.

Lightfoot introduces this qualification at the outset in order to avoid misunderstanding.

It will be time to enquire hereafter in what sense the Christian ministry may or may not be called a priesthood. But in attempting to investigate the historical development of this divine institution, no better starting-point suggested itself

than the absence of a distinctive priesthood. The reader ought to notice carefully that the institution whose development Lightfoot is about to trace is, as a whole, a "divine institution"."

"Strict loyalty to this conception," however, of a religion without a priesthood, "was not held incompatible with practical measures of organization ${ }^{3}$." "For communicating instruction and for preserving public order, for conducting religious worship, and for dispensing social charities "-so Lightfoot classes, more wisely than Hatch, the purposes to be kept in view- "it became necessary to appoint special officers 4." Lightfoot remarks that in the passages where St Paul speaks of the various offices in the church of his time, the permanent ministry, though lightly touched upon, is as spiritual a thing as the

1 Lightfoot, Philippians (ed. I869), pp. I79 foll.
2 Ibid. p. 180.
3 Ibid. p. 182.
4 Ibid. 
temporary ministry. "The faculty of governing not less than the utterance of prophecy... is an inspiration of the Holy Ghost1." But there is no specific priesthood.

After this prefatory statement Lightfoot begins the historical enquiry.

History seems to show decisively that before the middle of the second century each church or organized Christian community had its three orders of ministers, its bishop, its presbyters, and its deacons. On this point there cannot reasonably be two opinions. But at what time and under what circumstances this organization was matured, and to what extent our allegiance is due to it as an authoritative ordinance, are more difficult questions. Some have recognized in episcopacy an institution of divine origin, absolute and indispensable; others have represented it as destitute of all apostolic sanction and authority.... In this clamour of antagonistic opinions history is obviously the sole upright, impartial referee... . The doctrine in this instance at all events is involved in the history ${ }^{2}$.

At the beginning of the Acts, the twelve apostles are " the sole directors and administrators of the church. For the financial business of the infant community, not less than for its spiritual guidance, they alone are responsible." To relieve the pressure upon them, the diaconate was established. It was a novel thing, not borrowed from the levitical order, nor from the synagogue. It spread from Jerusalem to the Gentile churches. The presbyterate on the other hand was not new, but was taken over from the synagogue. Lightfoot connects its institution in

1 Lightfoot Philippians, p. I83. $\quad 2$ Ibid. p. 184. 
the Christian church of Jerusalem with the dispersion of the apostles which followed on the martyrdom of St James the son of Zebedee. This office also was extended to the Gentile churches. Jewish presbyteries already existed in all the principal cities of the empire. On their very first missionary journey St Paul and St Barnabas are described as appointing presbyters in every church. Doubtless the same thing was done everywhere.

In a note on the first chapter of the epistle 1 , Lightfoot had already established the fact that " bishops" and " presbyters" are synonymous terms. To be strictly accurate, they are not synonyms, but they describe the same officers from somewhat different points of view. He observes that the term " bishops" is applied only to the officers of Gentile churches. Why, we can only conjecture. Lightfoot says, with characteristic caution,

If we may assume that the directors of religious and social clubs among the heathen were commonly so called, it would naturally occur, if not to the Gentile Christians themselves, at all events to their heathen associates, as a fit designation for the presiding members of the new society ${ }^{2}$.

But he subjoins in a note that the evidence for this use of the word is slight, though he observes, after de Rossi, that the Christian brotherhoods were first recognized by the Roman government in their capacity of burial clubs. In this subordinate position Lightfoot places the fact out of which Hatch's whole theory was afterwards constructed.

1 Lightfoot Philippians, p. 93.

2 Ibid. p. 192. 


\section{Modern Anglican Criticism}

Lightfoot proceeds to the consideration of the other, more contested office.

It is clear then that at the close of the apostolic age the two lower orders of the threefold ministry were firmly and widely established; but traces of the third and highest order, the episcopate properly so called, are few and indistinct ${ }^{1}$.

He dismisses as " baseless" the opinion taken by Theodoret from Theodore of Mopsuestia, which weighed so much with many earlier Anglicans, that those who were first called apostles were afterwards called bishops. The substitution of the one name for the other would be inexplicable. "But in fact the function of the apostle and the bishop differed widely." The apostle held no local office.

It is not therefore to the apostle that we must look for the prototype of the bishop. How far indeed and in what sense the bishop may be called a successor of the apostles will be a proper subject for consideration: but the succession at least does not consist in an identity of office $^{2}$.

The history of the name itself suggests to Lightfoot a different account of the origin of the episcopate :

If bishop was at first used as a synonym for presbyter and afterwards came to designate the higher officer under whom the presbyters served, the episcopate properly so called would seem to have been developed from the subordinate office. In other words, the episcopate was formed not out of the apostolic order by localisation but out of the presbyteral by elevation : and the title, which originally was common to all, came at length to be appropriated to the chief among them ${ }^{3}$.

1 Lightfoot Philippians, p. 193.

2 Ibid. p. I94. ${ }^{3}$ Ibid. 
The diaconate began at Jerusalem; the presbyterate is first seen at Jerusalem; and Lightfoot says that if this surmise derived from the name is true, we might expect to find the first traces of the developed episcopate at Jerusalem.

Nor is this expectation disappointed. James the Lord's brother alone, within the period compassed by the apostolic writings, can claim to be regarded as a bishop in the later and more special sense of the term. In the language of St Paul he takes precedence even of the earliest and greatest preachers of the Gospel, St Peter and St John ${ }^{1}$... . The place assigned to him in the spurious Clementines, where he is represented as supreme arbiter over the church universal in matters of doctrine, must be treated as a gross exaggeration;...but his position, as it appears in St Luke and St Paul, explains how the exaggeration was possible. And this position is the more remarkable if, as seems to have been the case, he was not one of the twelve ${ }^{2}$.

On the other hand Lightfoot shows that St James is " not isolated from his presbytery." He acts in concert with it, as the head of it. Perhaps his personal qualifications reacted upon his office and " elevated it to a level which was not definitely contemplated in its origin."

Turning to the Gentile churches, Lightfoot sees no " bishops" there in the New Testament period; but like the great Anglicans of older days he marks two stages in the development. First, the apostles themselves exercise the superintendence of the

1 Gal. ii. 9.

${ }^{2}$ Lightfoot Philippians, p. 195. Hort Christian Ecclesia, p. 77, thinks it probable that he was taken into the place among the twelve left vacant by the death of his namesake. St Paul definitely speaks of him as an apostle (Gal. i. 19). 
churches, sometimes in person and on the spot, sometimes at a distance by letter or by message. Then, when the wider spread of the gospel made such superintendence impossible, they delegated " some trustworthy disciple who should fix his abode in a given place for a time and direct the affairs of the church there." The Pastoral Epistles, which Lightfoot accepted as St Paul's, present this second stage. Timothy and Titus are not, as earlier scholars affirmed, bishops of Ephesus and Crete: their position in those places is temporary.

But the conception is not altogether without foundation. With less permanence but perhaps greater authority, the position occupied by these apostolic delegates nevertheless fairly represents the functions of the bishop early in the second century. They were in fact the link between the apostle whose superintendence was occasional and general and the bishop who exercised a permanent supervision over an individual congregation ${ }^{1}$.

What then happened during the years between the last New Testament books and the earliest noncanonical writings?

As late... as the year 70 no distinct signs of episcopal government have hitherto appeared in Gentile Christendom. Yet... early in the second century the episcopal office was firmly and widely established. Thus during the last three decades of the first century, and consequently during the lifetime of the latest surviving apostle, this change must have been brought about. But the circumstances under which it was effected are shrouded in darkness ${ }^{2}$.

1 Lightfoot Philippians, p. 197. Lightfoot does not accept the patristic explanation of the apocalyptic "angels" of the churches as meaning their bishops.

2 Ibid. p. 199. 
One solution of the problem Lightfoot considers in detail, but thinks it insecure. It is the solution offered by Rothe in his Anfänge der Christlichen Kirche (I837). Rothe surmised that a council of the apostles who still survived was held after the fall of Jerusalem, resulting in a new organization of Christendom. The main object was to meet the advance of Gnosticism. Two fragments of early evidence may be alleged for the surmise. Hegesippus (as quoted by Eusebius) said that the remaining apostles and personal disciples of the Lord met after the fall of Jerusalem, and appointed a successor to the martyred St James,-but, as Lightfoot points out, he seems not to have known of any wider action on their part. Clement speaks of the apostles as having, at some date subsequent to their first appointment of elders, added a further regulation providing for a continued succession;-but, as Lightfoot again points out, Clement does not speak of the episcopate as a separate thing from the presbyterate: the regulation (supposing that there was a regulation) concerned the perpetuity of the office described by the one name or by the other indifferently ${ }^{1}$.

Of more importance than his criticism of Rothe's authorities was Lightfoot's observation upon the known phenomena. This is indeed the weightiest part of the dissertation.

1 A third piece of evidence on which Rothe relied was taken from one of the Pfaffian fragments of Irenaeus. Lightfoot not only showed its irrelevancy, but questioned its genuineness. It may now be said to be certain that these fragments are forgeries. 
Nor again does it appear that the rise of episcopacy was so sudden and so immediate, that an authoritative order issuing from an apostolic council alone can explain the phenomenon. In the mysterious period which comprises the last thirty years of the first century, and on which history is almost wholly silent, episcopacy must, it is true, have been mainly developed. But before this period its beginnings may be traced, and after the close it is not yet fully matured. It seems vain to deny with Rothe that the position of St James in the mother church furnished the precedent and the pattern of the later episcopate. It appears equally mistaken to maintain, as this theory requires, that at the close of the first and the beginning of the second century the organization of all churches alike had arrived at the same stage of development and exhibited the episcopate in an equally perfect form ${ }^{\mathbf{1}}$.

Certain parts of Rothe's hypothesis, however, appeared to Lightfoot to be correct. The emergency which consolidated the episcopal form of government was probably what Rothe alleged. Jerome's account of the rise of episcopacy bears this out.

To the dissensions of Jew and Gentile converts, and to the disputes of Gnostic false teachers, the development of episcopacy may be mainly ascribed ${ }^{2}$.

More important still :

Nor again is Rothe probably wrong as to the authority mainly instrumental in effecting the change. Asia Minor was the adopted home of more than one apostle after the fall of Jerusalem. Asia Minor too was the nurse, if not the mother, of episcopacy in the Gentile churches. So important an institution, developed in a Christian community of which St John was the living centre and guide,
1 Lightfoot Philippians, pp. 203 foll.
Ibid. p. 204. 
could hardly have grown up without his sanction : and... early tradition very distinctly connects his name with the appointment of bishops in these parts.

But to the question how this change was brought about, a somewhat different answer must be given.... There is no reason... for supposing that any direct ordinance was issued to the churches. The evident utility and even pressing need of such an office, sanctioned by the most venerated name in Christendom, would be sufficient to secure its wide though gradual reception. Such a reception, it is true, supposes a substantial harmony and freedom of intercourse among the churches, which remained undisturbed by the troubles of the times; but the silence of history is not at all unfavourable to this supposition. In this way, during the historical blank which extends over half a century after the fall of Jerusalem, episcopacy was matured and the catholic church consolidated ${ }^{\mathbf{1}}$.

Then, in his easy and delightful manner, embodying the results of so much research, Lightfoot takes the records of the various churches one after another.

The notices thus collected present a large body of evidence establishing the fact of the early and extensive adoption of episcopacy in the Christian church. The investigation however would not be complete, unless attention were called to such indirect testimony as is furnished by the tacit assumptions of writers living towards and at the close of the second century. Episcopacy is so inseparably interwoven with all the traditions and beliefs of men like Irenaeus and Tertullian, that they betray ro knowledge of a time when it was not. Even Irenaeus, the earlier of these, who was certainly born and probably had grown up before the middle of the century, seems to be wholly ignorant that the word bishop had passed from

1 Lightfoot Philippians, pp. 204 foll. 


\section{Modern Anglican Criticism}

a lower to a higher value since the apostolic times. Nor is it important only to observe the positive though indirect testimony which they afford. Their silence suggests a strong negative presumption, that while every other point of doctrine or practice was eagerly canvassed, the form of church government alone scarcely came under discussion ${ }^{\mathbf{1}}$.

Perhaps if Lightfoot's essay had stopped at this point, no one would ever have questioned his wholehearted acceptance of the apostolical origin of episcopacy. But the next two sections contain matter which seems to throw an uncertainty over his meaning.

The former of the two sections affirms that the original relation of the two offices, of bishop and presbyter, was not forgotten when episcopacy was universally established. The name of presbyter is still given to bishops by Irenaeus and the Alexandrian Clement. Ambrosiaster, Jerome, Augustine, still speak of the difference as one of custom and convention, not as inherent in the structure and conception of the church :

Nor does it appear, Lightfoot adds, that this view was ever questioned until the era of the reformation. In the western church at all events it carried the sanction of the highest ecclesiastical authorities and was maintained even by popes and councils ${ }^{2}$.

\section{Still more serious :}

Nor was it only in the language of the later church that the memory of this fact was preserved. Even in her practice indications might here and there be traced, which pointed to a time when the bishop was still only the chief member of the presbytery.

1 Lightfoot Philippians, pp. 224 foll.

2 Ibid. p. 228. 
The practical indications which he mentions are two. One is the system which is said to have prevailed at Alexandria, where Lightfoot believed that the presbyters not only appointed (as Jeromeasserted) their own bishop, but also consecrated him. The other was the decree of the council of Ancyra (in 3I4) forbidding chorepiscopi and " even city presbyters" to ordain presbyters and deacons without written permission from the bishop of the diocese.

Thus while restraining the existing license, the framers of the decree still allow very considerable latitude. And it is especially important to observe that they lay more stress on episcopal sanction than on episcopal ordination. Provided that the former is secured, they are content to dispense with the latter ${ }^{1}$.

Of course, however, Lightfoot was under no illusion about the usual practice of the church:

As a general rule, however, even those writers who maintain a substantial identity in the offices of the bishop and presbyter reserve the power of ordaining to the former. This distinction in fact may be regarded as a settled maxim of church polity in the fourth and later centuries. And when Aerius maintained the equality of the bishop and presbyter and denied the necessity of episcopal ordination, his opinion was condemned as heretical, and is stigmatized as "frantic" by Epiphanius 2 .

He goes on to dwell on three great names in the development of episcopacy. Ignatius makes the bishop the centre of unity. Irenaeus makes him the depositary of primitive truth. Cyprian makes him the vicegerent of Christ. With Cyprian we pass into the region of undisguised sacerdotalism.

1 Lightfoot Philippians, p. 230.

2 Ibid. p. 23 I. 
It is not the purpose of the work which we have in hand to criticize the opinions which we bring together; but it is not unreasonable to mention in passing that the two "practical indications" of a substantial identity of order between bishops and presbyters, which Lightfoot's candour felt constrained to adduce, are not beyond the reach of question. The text of the canon of Ancyra is not certain : it is extremely doubtful whether it gave permission to " city presbyters" to ordain, under whatever restrictions $^{1}$. There is no kind of proof, moreover, that chorepiscopi were mere presbyters, survivals from a time when functions were not differentiated. With regard to Alexandria, the statement of Jerome stands alone and unsupported ${ }^{2}$. This great and erudite man is sometimes reckless in his controversial statements ; and even if the statement here is correct, Jerome says no word that implies a consecration by the presbyters of the one whom they have elected for their head. For all that Jerome tells, us, the newly elected remains what he was before, a presbyter like the rest,-or the rest are bishops as much as $\mathrm{he}^{3}$. Thus the only "facts" alleged for non-episcopal ordinations after episcopacy was once established crumble to nothing, or next to nothing.

1 See Gore The Church and the Ministry (r889), pp. 370 foll.

2 The reading of the passage of Ambrosiaster quoted in support may be said to be certainly consignant (i.e. confirm) not consecrant; but even if consecrant were right, it would be an anachronism to identify it without more ado with the "consecrating" of a bishop. As for the testimony of Eutychius, no one would think of ascribing any value to it by itself.

3 See Gore ut supra, pp. 137 foll., 357 foll. 
To these considerations we may add that since Lightfoot's dissertation was published, a few new facts have come to light, which modify in some measure the situation as known in $\mathrm{I} 868$.

In the first place the Didache, or Doctrine of the Twelve Apostles (editio princeps I883), has been discovered. Its evidence is of ambiguous value; but from the way in which it speaks of men bearing the name of apostles as still visiting the churches, it helps to ease the belief that an order superior to the " bishops and deacons," whom it also mentions, was formed from the class called by Lightfoot " apostolic delegates" - the class represented by Timothy and Titus, the class which perhaps included "Andronicus and Junias, of note among the apostles." It at least prolongs the period in which "bishops and deacons" were not the highest ministers at work in Christendom ${ }^{\mathbf{1}}$.

Secondly, the discovery by Morin of a very ancient Latin version of the epistle of Clement ${ }^{2}$ makes it practically certain that what Clement wrote in a certain crucial passage was not what Lightfoot supposed. Lightfoot's translation of it runs :

And our apostles knew through our I-ord Jesus Christ that there would be strife over the name of the bishop's office. For this cause therefore, having received complete

1 See the interesting discussion of the "apostles" in T. M. Lindsay's Church and the Ministry in the early Centuries, pp. 74 foll.

2 Anecdota Maredsolana, vol. Ir., published in I894, after Lightfoot's death, which was in 1889 . 
foreknowledge, they appointed the aforesaid persons ${ }^{1}$, and afterwards they provided a continuance, that if these should fall asleep, other approved men should succeed to their ministration.

The word which Lightfoot renders " a continuance" is $\dot{\epsilon} \pi \iota \mu \nu \nu \nu^{\prime}$. It has no manuscript authority, but is a conjecture of P. Turner of Oxford, who died in r65I. The Latin version, et post modum legem dederunt, turns the scale decidedly in favour of $\dot{\epsilon} \pi \iota \nu \circ \mu \iota^{\prime}$ ('̇ $\pi \iota \nu \circ \mu \eta^{\prime} \nu$, the reading of the Codex Alexandrinus, is probably a mere itacism for the same), " an additional regulation." Thus, without any hesitation, the leading member of the Roman church, writing in 95 or 96 , ascribes the rule for succession in ecclesiastical office to a definite piece of legislation on the part of the apostles, in accordance with instructions from our Lord himself. Such a testimony cannot be passed over lightly, and it gives fresh weight to that theory of Rothe's, which already seemed to Lightfoot to be very weighty.

These two considerations are supplemented by the subsequent work of Lightfoot himself in two quarters. First, when the commentary on Philippians was published, the author of much of the Greek Ignatius was still to Lightfoot " the Ignatian writer," "the writer who. . . forges and interpolates the Ignatian letters." Lightfoot lived to prove, in a way that can hardly be seriously challenged again, that the

1 The reference is to the earlier passage, "So preaching everywhere in country and town, they appointed their first-fruits, when they had proved them by the spirit, to be bishops and deacons unto them that should believe." 


\section{8

Ignatian writer was Ignatius himself. The "extravagant exaltation of the episcopate" with which Lightfoot charges him is therefore to be charged to no one else but the great martyr-prophet of Antioch. And secondly, Lightfoot's labours upon the early history of the see of Rome convinced him that episcopacy there went further back than is sometimes believed. The epistle of Clement is often taken as evidence that Clement himself was not a bishop in our sense of the word. Lightfoot's mature opinion may be summed up in his own words:

So far as I can see, no adequate reason can be advanced why Linus and Anencletus [both of whom were before Clement] should not have been bishops in the later sense, as single rulers of the church $\mathbf{1}$.

It cannot be thought surprising that many of those who read Lightfoot's dissertation thought that it gave away the case for episcopacy as maintained by Bilson and Usher, by Hammond and Pearson. But Lightfoot was himself surprised. Friends urged him to alter the dissertation. He steadily refused. But in the preface to the sixth edition, published in

1 Clement of Rome, vol. I. p. 68 (ed. I89o). People often infer from the silence of Ignatius that the church of Rome was still unprovided with a bishop in IIO or II2. Such people forget that a difference would naturally be expected between letters to the churches which Ignatius had already visited and a letter to the great church towards which he was journeying. And his description of himself as "the bishop of Syria" shows that he supposed the Roman church to be at any rate familiar with the conception. Perhaps we may add that the same description implies an episcopate of a very different kind from that of later times, when every little city had its bishop. 


\section{Modern Anglican Criticism}

I88I, while affirming that his opinions were unchanged, he said:

But on the other hand, while disclaiming any change in my opinions, I desire equally to disclaim the representations of those opinions which have been put forward in some quarters. The object of the essay was an investigation into the origin of the Christian ministry. The result has been a confirmation of the statement in the English ordinal, "It is evident unto all men diligently reading the holy scripture and ancient authors that from the apostles' time there have been these orders of ministers in Christ's church, bishops, priests, and deacons." But I was scrupulously anxious not to overstate the evidence in any case; and it would seem that partial and qualifying statements, prompted by this anxiety, have assumed undue proportions in the minds of some readers, who have emphasized them to the neglect of the general drift of the essay.

The author of the article on the Bishop in the Quarterly Review for January I893, after quoting this passage, goes on to say:

Even after this statement the misrepresentations continued, and soon after the close of the Lambeth Conference of $1888^{1}$, Bishop Lightfoot felt it to be his duty to collect and print a series of extracts from his published writings bearing on this subject. There is nothing new in them. Their value is that they show distinctly what the author's opinion was and had been throughout; and that they were collected by himself. His trustees have done good

1 It was this conference which drew up the "Lambeth Quadrilateral," as it has been called, embodying the conditions on which the Anglican bishops are prepared to contemplate union with other bodies of Christians. The acceptance of " the historic episcopate" is one of the four conditions. 
service in reprinting them together with the essay ${ }^{1}$ and the following note:- "It is felt by those who have the best means of knowing that he would himself have wished the collection to stand together simply as his reply to the constant imputation to him of opinions for which writers wished to claim his support without any justification ${ }^{2}$."

The passages which Lightfoot collected include several from the dissertation itself, especially those which connect the establishment of episcopacy with St John. The last of them is this :

If the preceding investigation be substantially correct, the threefold ministry can be traced to apostolic direction; and short of an express statement we can possess no better assurance of a divine appointment or at least a divine sanction. If the facts do not allow us to unchurch other Christian communities differently organized, they may at least justify our jealous adhesion to a polity derived from this source ${ }^{3}$.

To these extracts Lightfoot added one from a sermon preached at Glasgow in 1882 :

While you seek unity among yourselves, you will pray likewise that unity may be restored to your presbyterian brothers. Not insensible to the blessings which you yourselves enjoy, clinging tenaciously to the threefold ministry as the completeness of the apostolic ordinance and the historical backbone of the church,... you will nevertheless shrink... from any mean desire that their divisions may be perpetuated in the hope of profiting by their troubles.

1 In Dissertations on the Apostolic Age, pp. 241-246. They are also printed at the end of the little volume consisting of this reprinted article from the Quarterly.

${ }^{2}$ Bishop Lightfoot, reprinted from the Quarterly Review, Macmillan and Co., I894, pp. 32 foll.

3 Philippians (ed. 1869), p. 265. 


\section{Modern Anglican Criticism}

$48 I$

"Divide et impera" may be a shrewd worldly motto ; but ..." pacifica et impera" is the true watchword of the Christian and the churchman.

This is from a "Church Congress" sermon of I887 :

But if this charge fails, what shall we say of her isolation? Is not this isolation, so far as it is true, much more her misfortune than her fault? Is she to be blamed because she retained a form of church government which had been handed down in unbroken continuity from the apostolic times, and thus a line was drawn between her and the reformed churches of other countries? Is it a reproach to her that she asserted her liberty to cast off the accretions which had gathered about the apostolic doctrine and practice through long ages, and for this act was repudiated by the Roman church? But this very positioncall it isolation, if you will-which was her reproach in the past, is her hope for the future. She was isolated because she could not consort with either extreme. She was isolated because she stood midway between the two. This central position is her vantage ground, which fits her to be a mediator, wheresoever an occasion of mediation may arise.

This is from his address at the reopening in 1888 of the chapel of Auckland Castle, which he restored, and where he now lies, at the feet of Cosin who founded it :

But while we lengthen our cords, we must strengthen our stakes likewise. Indeed the strengthening of our stakes will alone enable us to lengthen our cords with safety when the storms are howling around us. We cannot afford to sacrifice any portion of the faith once delivered to the saints; we cannot surrender for any immediate advantages the threefold ministry which we have inherited from apostolic times, and which is the historic backbone of the church.

M. 
But neither can we on the other hand return to the fables of mediaevalism or submit to a yoke which our fathers found too grievous to be borne, and a yoke now rendered a hundredfold more oppressive to the mind and conscience, weighted as it is by recent and unwarranted impositions of doctrine.

Such is Lightfoot's testimony to the episcopal order ${ }^{1}$.

The object which we have had before us in this enquiry has not been to ascertain whether the doctrine of the apostolical succession-succession from the apostles through an unbroken line of bishopsis borne out by the facts. Ours has been the humbler task of determining whether it has been the teaching of the Anglican church. We have considered to some extent the formularies in which the collective mind of the church has been expressed; we have considered in greater detail the way in which the living voice of her divines has made itself heard from age to age. The general result is fairly clear. The doctrine which Cranmer and his associates embodied in their ordinal has been upheld from that day to this by the great mass of Anglican writers who have touched upon it at all. Some of the greatest Anglican theologians have not had occasion to write about it-for instance, in their respective ages, William Forbes of Edinburgh, George Bull, Joseph Butler-but no one could doubt that they shared the belief. Simon Patrick, in his day, was able to

1 There is an excellent sketch of the history of the controversy from Lightfoot onwards in Lindsay Church and the Ministry, pp. 365 foll. 
show convincingly that the men were wrong who said that the belief was not held in our church after the reformation until the rise of Laud, or of Bancroft, or of Saravia. The present study will show that the belief was not dormant between Simon Patrick's time and the beginning of the tractarian revival. Steadily throughout the whole period from Cranmer down to Lightfoot it has been the standard teaching of the English church, though voices have spoken now and then in criticism of it, and those who spoke have not been cast out for what they said. Throughout the whole period the same authoritative formularies have received the assent, willing, or perhaps in some cases reluctant, of all her ministers. The only changes in those formularies have been such as to make them more explicit in the assertion. The only changes in the public law of the church have been made for the purpose of stopping any evasion of what was all along the intention of the law.

Towards the foreign non-episcopal churches the attitude of representative English churchmen has varied. Cranmer and other churchmen discussed the Augsburg Confession with German "orators" who came over to treat of union. Parker wished Martyr or Calvin to attend the conference at Poissy in I56I; they were as able, he said, to stand in defence of a truth, assisted by him whose cause it is, as the Romanist adversaries striving against God. "If we were all careful," he said, " to help the re-edifying of so great a church as France is to 


\section{Modern Anglican Criticism}

Christ again, it could not but turn to our own quiet at home, to have more friends in conjunction of religion." The sending of commissioners to the synod of Dort was the act of the king, not of the church ; but no record of protest is known, though the commissioners maintained an independent attitude at the time, and the church of England accepted no responsibility afterwards for what was done at it. The encouragement given by high authorities to the work of John Dury among the foreign protestants, the correspondence of Sharp and Wake with Jablonski and the Prussians, not to mention more private and personal expressions of goodwill, were signs that the church of England, through her leading men, felt that the cause of the foreign protestants was in the main her cause.

So much was this the case that communion was freely practised on both sides-at least where the foreign churches permitted it. Saravia, while still in Holland, communicated when he could at the English service. Wake's correspondence shows what numbers of French protestants did the same in Paris. Saywell shows how foreign protestants visiting England were admitted to communion here. In return, Cosin says that English churchmen were not forbidden to communicate in the congregations of foreign protestants in England. He himself communicated with them abroad. But even Usher expressed hesitation about it. Probably men like Scudamore and Clarendon, Morley and Hickes, who definitely refused to do so, were a minority; but, 


\section{Modern Anglican Criticism}

as we have pointed out, the very fact that Cosin pleaded so vehemently that it was the right thing to do, while others declined, is a sufficient indication that there was no public, official, recognized intercommunion.

That there were other reasons for refusing to communicate with the foreign churches is clear enough; but the reason which most concerns us here is that which was derived from the uncertain validity of their orders, and consequently of their sacraments. This was a growing reason. Probably in the early times of the reformation, when the dust of contest was thick in the air, the question hardly emerged. Things were assumed to be right. Archbishop Parker speaks in one place of "Luther, Calvin, and other orthodox clergymen ${ }^{1}$, " - - and indeed Calvin was strictly " a clergyman," for he had received minor orders. Hooker, who was aware that Beza had none, yet shows that his sympathy was with Beza rather than with those who challenged his orders at Poissy ${ }^{2}$. By and by, a certain number of English theologians began to express their doubts. Jeremy Taylor frankly says that he knows not what to think. Waterland, in lofty scorn of consequences, sticks to principle and pronounces that their orders are invalid. To Heber, though there is a tinge of irony in his language, their ministers, " in the view of an episcopal church," if not in his own, are mere laymen. Others defended them,-mostly on the

1 Parker's Correspondence, p. II 2.

2 Eccl. Pol. bk vir. ch. xiv. § r I. 
ground that if their orders were invalid, the churches were no churches; and they could not face that result. A few, like Field and Mason, and Forbes of Corse, and Wesley afterwards, took the definite line suggested by Jerome and the mediaevalists, that the power of ordination is inherent in the presbyter's office: they did not enquire whether the men who started the new successions were in all cases presbyters. They acknowledged that nothing but necessity could justify the presbyter in using this power. They took it for granted that the necessity was there. Others went on safer ground. Hooker, Ferne and Thorndike recognized no such latent power in the presbyter as such ; but they recognized that churches must do the best for themselves that they can, and were ready, if the necessity was proved, to receive on a ministerial footing those whom the hard-pressed churches had made ministers, without asking after the status of those who ordained them. No Anglican theologian of repute has ever maintained the validity of presbyterian orders except where no others could be had. Many of those who admitted their validity on that proviso persuaded themselves that it was a temporary concession, and that before long these defective churches would recover an episcopate. Naturally, this was the case with the earlier theologians-a Saravia, a Hooker-rather than with the later ones, when presbyterian traditions were more inveterate ${ }^{1}$.

1 These observations hold true of the presbyterian church in Scotland as much as of any other foreign church. 
With regard to dissenting ministries in England there were no two opinions. Those who denied the validity of presbyterian ordinations abroad denied their validity a fortiori in England. No plea of necessity here could for a moment be allowed. Some of those who most stoutly championed the validity of those orders beyond the sea, sternly denied it here. Of these, a few took the Cyprianic ground that whatever validity there might otherwise have been in such ordinations was nullified by schism. Others, like Cosin, attempted no logical defence. Presbyterian orders might be all very well at Charenton, but they were quite a different thing near Durham. To most, however, the question was of little practical importance-at least after $\mathbf{1 6 6 2 .}$ No man in presbyterian orders could be admitted into the ministry of the church of England without a fresh ordination, whether he had received his former orders abroad or at home. And so long as he did not seek such admission, his status was only a matter of academic concern. However valid his orders might be, there was no idea of intercommunion with him or the body to which he belonged, so long as it remained in schism. If Wesley had succeeded in persuading the wandering Greek bishop to consecrate him bishop when he ordained his preacher a priest, it might have made Wesley's subsequent ordinations valid, but they would have remained schismatical.

It was not until Wesley and the subsequent movement began to break up the discipline of the church 
of England that any considerable number of churchmen conceived the idea of communion between the church and the separated bodies, so long as they remained separate. Separatists had often been invited and urged to come to church, to come to the communion of the church. It was a way of stopping their separation from becoming final and complete. As Baxter said, it was " a healing custom." So long as men could find it consistent with conscience to make an "occasional " communion with the church, they were not wholly lost to it. But those who took this line of encouraging occasional communion had no idea of recognizing the separatist bodies to which such communicants were attached. They ignored them. The thought of going in return to the conventicle and communicating there was wholly foreign to most minds. The one thing which men wished was to prevent a temporary estrangement from hardening into permanent schism. Even the least dogmatic of divines hoped to bring the malcontents back, and to gather them round the ancient church and its accredited ministry. If the methods which they adopted were not always logical, the purpose was admirable, and the largeness of spirit very attractive. A Tenison had no wish to merge the church of England in a combination of amicable sects, but to win the sects away from their sectarianism into the unity of the church. 


\section{APPENDIX A}

HAS THE REFORMED CHURCH OF ENGLAND EVER ADMITTED INTO HER MINISTRY MEN NOT EPISCOPALLY ORDAINED?

IT might have been thought that this question was settled by the Preface to the Ordinal, even in its earlier form, before the alterations of 1662 and the Act of Uniformity. But it has been held both in earlier days and in our own that before the restoration period it was possible for men to hold ministerial office in the church of England without episcopal ordination, and that an Act of Parliament was expressly framed to admit of it in the case of foreign orders.

\section{The Act I3 Eliz. cap. I2, § I.}

This Act provides as follows:

That the churches of the queen's majesty's dominions may be served with pastors of sound religion, be it enacted ...that every person under the degree of a bishop which does or shall pretend [i.e. claim] to be a priest or minister of God's holy word and sacraments by reason of any other form of institution, consecration, or ordering than the form set forth by parliament,... before the feast of the nativity of Christ next following shall in the presence of the bishop 
or guardian of the spiritualities of some one diocese where he has or shall have ecclesiastical living declare his assent and subscribe to all the articles of religion which only concern the confession of the true Christian faith and the doctrine of the sacraments comprised in a book entitled : Articles, etc.

It is contended that this clause is designed to permit persons in presbyterian orders to qualify for ministerial office in England by subscribing to the articles, without any fresh ordination. The following facts are against this view.

(I) That this was not the intention of the Act is certain. Bishop Burnet, who would have entertained no objection to such a provision, pointed out that the object of parliament was quite different. It was to exclude priests who had received orders under Mary or Henry VIII (or in foreign countries) unless they gave proof of a cordial acceptance of the reformation $\mathbf{1}$.

(2) The ordinal, with its preface and all, was still in force as " the form set forth by parliament." It would be strange, without fuller reference to that form, to admit in such vague terms persons claiming to have been made ministers in a manner subversive of the whole purport of the preface. The language of the Act of I57I suits any form of ordination by bishops, western or eastern : it is incompatible with a form of ordination by any other kind of agents.

(3) Hardwick ${ }^{2}$ shows that the Act, so far from being regarded as a concession by the puritan (i.e.

1 Birch's Life of Tillotson, p. 172.

2 History of the XXXIX Avticles, p. 228 (ed. 1859). 
presbyterian) party at the time, " encountered the hostility of the Admonition to Parliament put forth in the following year."

(4) The Act of I57I does not appear to have been appealed to in any of the cases which came before the law courts,-not even by Travers, who quotes it as applying only to Roman orders, though he suggests that it might be treated as offering a loop-hole for himself.

(5) The attempt was made in the case of a man named Smith to construe the word " only" in the Act as restricting subscription to a certan number of the XXXIX articles. Smith, so far as is known, was duly ordained; but if his contention had been made good, it would have been possible for a man to pass under the Act who rejected article XXXVI Of Consecration of Bishops and Ministers. This was overruled by the judges. They ruled that the Act required subscription to all the articles without exception. The word "only" applies not to what follows, but to the word "which," as was frequent in the language of the period ${ }^{\mathbf{1}}$.

\section{Sample cases.}

It is well known that from mediaeval times a distinction in law was drawn between what were called beneficia simplicia and beneficia curata. To the former, which were "sinecures," laymen were frequently presented. Deaneries, cathedral canonries, and the like, were held by laymen, under

${ }^{1}$ See Collier Eccl. Hist. (ed. 1846), vol. vi. p. 489. 
dispensations ${ }^{1}$. Thomas Cromwell, for instance, was Dean of Wells. Isaac Casaubon, described as mere laicus, was a canon both of Canterbury and of Westminster. The thing was an abuse, and Englishmen complained when so many foreigners, like Peter du Moulin the elder, were appointed to these posts. But it has yet to be shown that such foreigners were admitted to minister the sacraments. Some of them certainly preached; but many people, especially in Elizabeth's reign, were licensed to preach and read prayers who were expressly forbidden to perform any function belonging strictly to the priesthood.

It must also be observed that until quite recent times men could legally be instituted to benefices, even with cure of souls, before ordination, though the benefices were voidable if the incumbents were not ordained priests within a given period. The door was thus opened to irregularities; but whether such irregularities actually occurred in consequence seems uncertain. At any rate the custom did not originate with the reformation, and if insufficiently ordained men took advantage of it, these were merely cases of carelessness on the part of individual officers, not implying the deliberate consent of the church.

Certain cases of doubtful orders have attracted attention.

1 Numerous examples are given by E. Denny in his valuable paper on The English Church and the Ministry of the Reformed Churches (Church Historical Society publications, No. 57). 
(I) Perhaps the most celebrated is that of Whittingham, Dean of Durham. In the eye of the law he was a layman. In the case of Barrington, the Chief Justice Hobart ruled that by special license from the king a dean might be a layman, " as was the Dean of Durham ${ }^{1}$." But Whittingham would not at all accept that position. He stoutly asserted the validity of his call to the ministry, in spite of the English law, and presumed to minister the sacraments.

By way of answer, he confesseth that he is neither deacon nor minister according to the order and law of this realm. But that he is a mere layman he denieth. For, saith he, I was ordered in Queen Mary's time in Geneva, according to the form there used, which I think to be one in effect and substance with the form now used in England, or allowed of in King Edward's time. Which orders of mine were as agreeable to the law of this realm as any other form, until the eighth year of the queen's majesty's reign.

It is the Chancellor of the Archbishop of York who writes this report to the lords of the council. $\mathrm{He}$ rejects with severe condemnation Whittingham's view of the law:

The latter part of his answer is wholly untrue.... For in the first year of her majesty's reign, in the same moment of time and by the same authority that Queen Mary's ordering was repealed King Edward's was revived; and many learned and godly ministers were made before the eighth year and since the first of her majesty's reign.

1 Denny, ut supra, p. 60. 
An attempt was made by one of the lay members of the commission which investigated the case to prejudice the judgment.

It could not but be ill taken, he wrote to Burghley, of all the godly learned both at home and in all the reformed churches abroad, that we should allow of the popish massing priests in our ministry and disallow of the ministers made in a reformed church.... For himself [the writer]... he thought in conscience he might not agree to the sentence of deprivation for that cause only ${ }^{1}$.

Archbishop Sandys strongly opposed this presentment of the case. He too wrote to Burghley:

The dean hath gotten mo friends than the matter deserveth. The discredit of the church of Geneva is hotly alleged. Verily, my lord, that church is not touched. For he hath not received his ministry in that church, nor by any authority or order from that church, so far as yet can appear ${ }^{2}$.

The fact was that Whittingham had been ordained, if it could be called by that name, by some members of the exiled English congregation. Strype is perhaps going beyond the evidence when he says that they were "a few lay persons in a house at Geneva." Whittingham produced a certificate, wholly informal in character, dated no earlier than July 8, I575, to the effect " that it pleased God by lot and election of the whole English congregation there orderly to choose $\mathrm{W}$. W. to the office of preaching the word and ministering the sacraments." When

${ }^{1}$ See the whole account in Strype Annals (ed. 1824), vol. II. part II. pp. 168 foll.

2 Ibid. p. 620. 
this certificate was set aside, another was produced which put "the suffrages" in place of "lot and election " and added " that he was admitted minister, and so published, with such other ceremonies as there [at Geneva] is used and accustomed ${ }^{\mathbf{1}}$." Among the persons taking part in the transaction there may have been some who were in holy orders; but it is not certain. Whittingham himself does not seem to have laid stress upon the point.

Sandys, whose exile had been spent at Strassburg, told Burghley that such measures had never been attempted by " any English church in Germany," and that it was quite unnecessary at Geneva, as there were "sufficient ministers" among them to supply the room ${ }^{2}$.

But, he added, if his ministry without authority of God or man,-without law, order, or example of any church,may be current, take heed to the sequel. Who seeth not what is intended? God deliver his church from it. I will never be guilty of it $^{3}$.

Whittingham's case was never finally decided, because he died within six months of his examination by the commissioners. But Archbishop Whitgift was certainly right when he said that "if $\mathrm{Mr}$ Whittingham had lived, he had been deprived,

1 Strype Annals, vol. Ir. part Ir. pp. I7 I, 172.

2 There was even a bishop there for some part of the timeCoverdale.

3 Ibid. p. 620. Hutton, then Dean of York, afterwards Archbishop, appears to have taken Whittingham's part with some vehemence. In view of his own expressed views of episcopacy (see above, p. 30) his reasons must have been personal, not theological. 
without special grace and dispensation ${ }^{1}$." The queen had already said in her letter to Archbishop Sandys that the commission was to " enquire of his ministry," and that if he were not " ordered by some superior authority, according to the laws and statutes of our realm," they were to dismiss him ${ }^{2}$.

(2) The second case which has been alleged is that of John Morison ${ }^{3}$.

He had been ordained by the General Synod of the county of Lothian. During the sequestration of Archbishop Grindal, Aubrey, his vicar general, issued a license to Morison to preach and administer the sacraments throughout the province of Canterbury. The " consent and express command " of the archbishop himself are recited in the license. It has been suggested that one of the still surviving Scotch bishops may have taken part in Morison's ordination; but if that was the reason why Grindal consented to the license, it is strange that the fact was not mentioned in the license, where other facts are spoken of which made the ordination seem somewhat like a normal one. It is perhaps more to the point to observe that the license contained two saving clauses,-quantum in nobis est et de jure possumus, - and quatenus jura regni patiuntur. These clauses may be taken to imply a consciousness that Aubrey, and his master, were perhaps acting ultra vires, and that Morison must take the risk.

1 Strype's Whitgift, vol. III. p. 185.

2 Strype Annals, vol. II. part II. p. I7I, cf. p. I70.

3 The facts are given by Denny, ut supra, pp. 62 foll., from Strype's 'Grindal, pp. 402 and 596. 
On the whole, the case must be considered to be made out. But the license was not issued by the church of England, though it was issued by authority of its highest minister. It was not covered by the law of the realm, and was in direct contravention of the prayer-book of the church.

(3) Per contra we have two cases of men who were deprived during this period as incapable of the preferments which they held. Of these the first is that of Townsend, who had been instituted by his bishop, Parkhurst of Norwich, but was ejected in I570 on the ground that he was not properly qualified, although he is described as clericus. There seems ${ }^{1}$ reason to think that he had received protestant orders of some kind.

(4) The other is that of a man named Thwaites, who was deprived in 1575 or 1576 under the Act of I57I because (I) he was not a minister according to the ordinal prescribed by law, and (2) had not subscribed to the articles as required by the Act. It does not appear to be certain what form of ordination Thwaites had received, whether Marian or presbyterian :-in either case his refusal to sign the articles was sufficient to disqualify him. But the probability is that his refusal to sign arose from ultra-protestant opinions rather than the opposite ${ }^{2}$.

(5) The evidence in these two cases is inconclusive, but it is otherwise with the celebrated case of Walter Travers. Here the facts are undisputed,

\footnotetext{
1 See Denny, ut supra, p. 8r.

2 Denny, p. $4^{8}$.
}

M. 
and the bearings of them are plain. Walter Travers, " disliking the way of ordination by bishops according to the English book, went over to Antwerp, and there was made minister by some elders and ministers, and namely by Villers and Cartwright, in a private congregation, after the form of Geneva ${ }^{1}$." In I584 Travers applied to be made Master of the Temple. Archbishop Whitgift objected that he was " either in no degree of the ministry at all, or else ordered beyond the seas, not according to the form in this church of England used 2." Travers was told that he must be duly ordained before his application could be thought of. His reply was an able one. $\mathrm{He}$ wrote to Burghley:

Whereas I am required to enter into the ministry again, being once sufficiently called thereunto, according to the rules of God's most holy word, with prayer and imposition of hands, and agreeably to the order of a church of the same faith and profession with this church of England, as may appear by the testimonial I have thereof, may it please your good lordship to consider of the reasons following concerning the matter.

The calling to the ministry is such an action as he that in a church orthodox, and not heretical or schismatical, hath once received sufficiently for the substantial points to be observed in it by the ordinance of God in any part of the holy catholic church, wheresoever he may after be required to any place wherein he may exercise that calling, is not to be urged to any new imposition of hands and vocation to the ministry, but is to be acknowledged sufficiently qualified for any action that a minister may perform.

1 Strype's Whitgift, vol. I. p. 477.

2 Ibid. p. 34I. 


\section{Appendix A}

Travers gave good reasons for this assertion, and then went on :

All the churches professing the gospel receive likewise to the exercise of the ministry among them all such as have been called lawfully before in any of the churches of our confession. And in the church of England not only the same hath been always observed unto this day, but also priests ordered according to the manner of the church of Rome, to the r3th year of her majesty's reign, were suffered to do any work of the ministry and to enjoy the livings pertaining thereunto without any manner of question of other calling than the order of priesthood which they had received. Since that time, it was yet lawful for them as curates to do any act of ministry; only it is provided by statute that from that time they shall not enjoy the livings, except they first assigned the articles agreed on in the convocation house, $\mathbf{1 5 6 2}$. So that to this day it is not required of them to be called again according to the order now established, but only that they subscribe according to the statute.

His language implies that in his opinion the statute was only intended for priests in Roman orders. He goes on :

The reason of all which I take to be, beside that the calling to the ministry by the ordinance of God ought to be but once and not repeated, the great inconvenience feared of such repetition, as the disunion of the churches, whose communion is broken by such offence, and the making void of all former acts of ministry done by them....Therefore to avoid the renting of the churches one from another, and rebaptization of those who had been baptized before, and the annulling of marriages solemnized before by others, with many such like, it hath been always thus practised in this church, and all other churches of our profession. 
He then asks whether he might not be allowed to pass under the Act by subscribing :

Whereupon I humbly beseech your good lordship to consider whether that subscribing to the articles of religion ...(which most willingly and with all my heart I assent unto as agreeable to God's word), such my doing, by virtue of that statute, do not as fully enable me for dealing in the ministry as if $I$ had been at the first made minister by the form established in this church ${ }^{1}$.

In spite of his great influence with Burghley, Travers did not obtain the coveted mastership. He was, however, lecturer at the Temple, and there preached in the afternoons in reply to Hooker's " pure Canterbury" delivered in the mornings. At length, early in 1586, Whitgift inhibited him. Travers appealed against this inhibition. He sent in a fresh paper of reasons why his Antwerp ordination should be accepted. The paper is preserved, with Whitgift's animadversions in the margin. Naturally it went over the same ground as before. To Travers' contention that ordination in one country ought to hold good in another Whitgift assents, but adds

And yet the French [reformed] churches practise otherwise, neither will they admit any of our ministers, ordained according to the laws of this church, to exercise his function among them without a new kind of calling according to their platform.

\section{Travers writes :}

The universal and perpetual practice of all Christendom, in all places and in all ages, proveth the ministers lawfully made in any church of sound profession in faith ought to be acknowledged such in any other.

1 Strype's Whitgift, vol. III. pp. II 5 foll. 
The animadversion is :

Excepting always such churches as allow of presbytery, and practise it.

Travers quotes the case of St Polycarp, who was allowed to celebrate the eucharist at Rome. "This is true," runs the grim comment,

but Mr Travers's case is far differing from it. For Polycarpus went not to Rome to be made minister, but being ordained minister according to the order of the church wherein he lived was suffered to execute his function at Rome. But Mr Travers, misliking the order of his country, ran to be ordered elsewhere by such as had no authority to ordain him, to the contempt of the ministry of this church, and the manifest maintenance of schism. And as well may $\mathrm{Mr}$ Cartwright and his adherents now make ministers at Warwick to serve in this church of England as he and Villiers might have done at Antwerp.

Travers affirms that

In this church of England many Scottish men and other, made ministers abroad, have been so acknowledged, and executed their ministry accordingly, and yet do still among us.

The archbishop's note is laconic, but of great historic interest:

I know none such: and yet their case is far differing from his.

Travers says that afore Mr Whittingham's case no objections were raised, and that Whittingham himself was not ejected. Whitgift observes:

This is untrue. For if Mr Whittingham had lived, he had been deprived, without special grace and dispensation. Although his case and $\mathrm{Mr}$ Travers are nothing like. For 
he in time of persecution was ordained minister by those which had authority in the church persecuted. But $\mathrm{Mr}$ Travers in the time of peace, refusing to be made minister at home, gaddeth into other countries to be ordained by such as had no authority, condemning thereby the kind of ordering ministers at home.

Travers returns to the Act of I3 Elizabeth and the terms on which it admitted popish priests to serve without reordination. Whitgift remarks :

When the like act is made for his ministry, then may he allege it. But the laws of this realm require that such as are to be allowed as ministers in this church of England should be ordered by a bishop, and subscribe to the articles before him.

Travers cites the language of the XXIIIrd article as in his favour. Whitgift writes in the margin

This doth not justify his calling.

Lastly Travers avers that the late Archbishop of Canterbury, Grindal, knew his circumstances and was content that he "should preach in England." The Bishop of London, Aylmer, had been contented that he should preach at the Temple, as he had now done for six years. Whitgift himself, he said, had taken no exception. The archbishop notes :

This is to abuse our patience. He never allowed of your kind of calling; neither can he allow of it ${ }^{1}$.

(6) We will next consider the case of the celebrated Saravia. It might have been supposed that he was admitted to his canonry at Canterbury

1 Strype's Whitgift, vol. IIr. pp. I 82 foll. 
on similar terms to those on which Casaubon and others were admitted. But he could not have been thus admitted to the parochial cure which he held; and it is certain that he did not hold a quasi-laic position in the church of England. The one fact about him which every educated English churchman knows is that he gave the last sacraments to Hooker. Was he qualified to do so by any other ordination than what he had for his ministry in the reformed church in Holland?

Bishop John Wordsworth seems to assume that he had received Roman orders before coming to England ${ }^{1}$. This is most unlikely. There was indeed a succession of bishops in Holland until the death of Van Stryen in $1594^{2}$. But Saravia's father was a protestant minister before him. How would a protestant minister's son obtain orders from those bishops without leaving the community of his father?

It is natural to suppose that Saravia was ordained when he took up his abode permanently in England in 1587 , if indeed it was not done during his earlier sojourn in this kingdom. That no record of his ordination here is to be found is no proof that he was not ordained. The more curious fact is that he makes no allusion to a fresh ordination in his prefaces, where so many biographical notes are to be found. Why, when he urges his countrymen to restore episcopacy in their church, does he not advise

1 Ordination Problems, p. 126.

2 Neale Jansenist Church of Holland, p. I 5. 
them to do as he had done and obtain the better ordination of an episcopal church? Why does he take what appears to be the opposite line of saying that there was no difference between the two churches and that his reason for joining the church of England was to show it? If he was, in fact, episcopally ordained in England, we can only suppose that his silence on the point was due to the wish not to frighten his former countrymen away from a reform in the catholic direction by seeming to condemn their existing orders as void. That he did not consider them as wholly void is plain from his own words, though he infinitely preferred the catholic way of ordination.

But however his silence on the matter is to be explained, his language about episcopacy and ordination is such as to make it almost inconceivable that he should not have taken the opportunity to regularize his priestly status. And another will besides his own was concerned, and that a very masterful one. His benefices were under the eye of Whitgift, and there is reason to think that Whitgift had a hand in obtaining some of them for him. Was Whitgift the man to appoint, or to connive at appointing, a person in presbyterian orders to English benefices, especially benefices with cure of souls? How could he have done so within a year or two of saying, "I know of none such," in the case of Travers? It is true that Whitgift drew a distinction between the case of Travers and that of men born and bred in the defective foreign 
churches; but his "I know of none such" shows how he would have regarded the intrusion of the foreign presbyter-made presbyter. It may be added that Bancroft collated Saravia to another parochial benefice in his own diocese and patronage. Bancroft was at least as unlikely as Whitgift to advance a man of defective orders ${ }^{1}$.

(7) The next case is that of De Laune ${ }^{2}$. At present the closing statement of Birch, or Cosin, with regard to him, that De Laune was admitted to a benefice without reordination, stands unverified. But it may be accepted as true. Bishop Overalland probably other bishops of the period-was willing to institute the man at the man's own peril. If : after the time fixed by the law parishioners or others objected that he was not in priest's orders, the man would be obliged to defend himself and his

1 The Rev. G. F. Hodges has pointed out to me that James Owen, a presbyterian controversialist of the end of the I 7 th century, who inveighs against Saravia along with Laud as having introduced the belief of the jus divinum into England, gives a list of foreigners who, he thinks (in most cases wrongly), held English benefices on the strength of presbyterian orders, but does not include in it the name of Saravia, though he had mentioned him but a few pages back. This may possibly indicate that Owen knew that Saravia had received episcopal orders. It would certainly have enriched Owen's list if he could have put Saravia in it. On the other hand he seems to imply in one place that Dury was the first man to be reordained on joining the church of England-a statement which he took from Prynne, as perhaps Cosin did also. See his pamphlet A plea for Scripture Ordination, pp. 66, II7 (published in 1694). $\mathrm{Cp}$. The Validity of the Dissenting Ministry, or the Ordaining Power of Presbyters (an abridgement of the former pamphlet, but with some additions, published in I 716), pp. 62 foll.

2 See above, p. 79. 
orders in the bishop's court, and perhaps lose his benefice. Overall could not feel sure that De Laune's orders would prove sufficient in the eye of the law; and his uncertainty in the matter is good evidence that such occurrences were at any rate rare and the state of the law undetermined. His offer to institute, however, on these terms shows that Overall was unwilling to raise any other difficulty besides the legal one. Apparently he did not feel that the institution would inflict a wrong upon the parishioners, or be a cause of scandal to the church. This was, of course, only Overall's individual view ; and even Overall was not infallible. At the same time it is certain that Overall made a great distinction between the foreign ordination and ordination by unauthorized Englishmen.

(8) A few other cases have been at times brought forward but must now be considered settled against the presbyterian claim. They may be mentioned here together. John Véron is proved to have been duly ordained by Bishop Ridley ${ }^{1}$. Peter Du Moulin, the younger, is expressly recorded to have been ordained by Bishop Williams2. Gataker, the wellknown puritan, was ordained by Sterne, Bishop of Colchester ${ }^{3}$.

1 Denny, ut supra, p. $5^{8}$.

2 Denny, p. 78, quoting Hacket's Scrinia Reserata.

3 Denny, p. 8o. Mr Denny in the same note makes a curious slip concerning the date of Bishop Patrick's ordination by the presbyterian classis. He was only eight years old in 1634 . 


\section{Some general statements.}

Writers on behalf of the recognition of presbyterian orders make much use of certain stock quotations, in which it is affirmed in general terms that such orders were at one time recognized. Among the best known are the following.

(I) Travers' statement given above :

Many Scottish men and other, made ministers abroad, have been so acknowledged.

Whitgift's comment, "I know none such," is sufficient.

(2) Bishop Hall's Defence of the Humble Remonstrance, section XIV:

[First] The sticking at the admission of our brethren returned from reformed churches was not in the case of ordination but of institution; they had been [probably " had" is used in the conditional sense = would have been] acknowledged ministers of Christ without any other hands laid upon them; but according to the laws of our land they were not, perhaps, capable of institution to a benefice unless they were so qualified as the statutes of this realm do require. And secondly I know those, more than one, that by virtue of that ordination which they have brought with them from other reformed churches have enjoyed spiritual promotions and livings without any exception against the lawfulness of their calling.

Hall is speaking of two different classes of men. The first are Englishmen who have been ordained abroad, like Whittingham or Travers. The second are Scotchmen or foreigners. Those of the former class, he says, could not lawfully be admitted to 
benefices, even though their orders might have been considered valid. The law of the land was against it. Bishops might have their own opinions about the sufficiency of the ordination of these men, but they could not institute them with any prospect of security. Of the second class, consisting of such men as De Laune or Morison, Hall says that he knew " more than one" who had received preferment. He does not say how it came about that the law appeared to admit of the institution of this latter class while precluding that of the former. The law-I3 Eliz. cap. I2-dealt with both classes alike. But the prevailing sentiment of churchmen made a broad difference between the two classes, and was ready to make an allowance for the second which it refused to the first. It is of course possible that Hall may have been mistaken about the facts, as he appears to have been mistaken about the law; but it is also possible that he was right, and that a few cases like that of De Laune were to be found. "More than one" is a cautious phrase. But, few or many, such cases were contrary both to the prayer-book and to the statute.

(3) Cosin's language has been quoted on p. 224. Cp. p. 229 .

It is clear that De Laune's case was one of those to which Cosin alludes. Indeed, considering how much Cosin takes the line of a special pleader, it would not be unnatural to suppose that his " some" is a generalization of De Laune, with perhaps Whittingham thrown in. 


\section{(4) Clarendon. See p. I77.}

It may be questioned whether Clarendon's sentence beginning "This was new" is a statement of Clarendon himself, or whether it is part of his report of an argument which he had heard in the house, like the sentence which follows. In any case Clarendon is probably not speaking from personal knowledge. He was most likely acquainted with Hall's Defence of the Humble Remonstrance. He was certainly intimate with Cosin and acquainted with Cosin's views on this particular question.

(5) Burnet, History of his own Time (ed. I838), p. I25, says in reference to the same Act of Parliament of which Clarendon is here speaking:

Another point was fixed by the act of uniformity which was more at large formerly; those who came to England from the foreign churches had not been required to be ordained among us; but now all that had not episcopal ordination were made incapable of holding any ecclesiastical benefice.

Burnet is probably dependent upon Clarendon. (6) Fleetwood, whose words will be seen on p. 37I, is still less of an independent authority. The system to which he refers, if it ever existed, had passed away before he was born, and he only repeats what he had learned from Cosin, whose letter to Cordel he prints, and perhaps from Burnet or from Clarendon.

Putting all these sources together, we shall probably be right in concluding that there were a few instances of the admission of men in foreign presbyterian orders to English cures. But the 
church of England in its corporate capacity did not sanction them, nor did the law of the realm. Current opinion may have favoured them, but they were none the less a defiance of the established rule.

Two other sets of facts must be briefly mentioned.

I. In the I8th century and the beginning of the Igth the greater part of the missionary work of the English church in India was done through the instrumentality of foreign Lutheran ministers. Many of these men were not in the first instance sent out by the English societies, but by the Danish mission, and were subsidized and employed by the English. Some of them, like the apostolic Swartz, having begun in this way were gradually absorbed into the operations of the English church in India; Swartz became to all intents and purposes an Englishman, even to writing his name in this form.

The anomaly was striking; but it will be seen by the expressions of Bishop Heber, quoted on p. 436 , that the orders of the Lutheran missionaries were by no means recognized by the church of England and its representatives. To Heber, much as he admired them, they were laymen. If sometimes they read prayers for English congregations who had no chaplain, and preached to them, it was not because their priesthood was acknowledged; some of the missionaries did so when they had received no ordination at all ${ }^{\mathbf{1}}$. Those whom they ordained, Heber ordained afresh when he could.

1 See the account of the younger Kohlhoff in Pearson's Memoirs of Swartz, vol. II. p. I26. 
II. Perhaps the nearest thing to a recognition of presbyterian orders in the Anglican communion is to be found in the history of the church of Scotland. As has been stated in the text, p. 275, no attempt was made, either in I6Io or in I66I, at the reintroduction of episcopacy into that country, to reordain the mass of the presbyterian clergy, though individual clergymen who desired it were reordained. Presbyterian and episcopalian ministers worked side by side in the same church, and no distinction appears to have been made. This was the "expedient" which in I66o commended itself at first for England also to a mind as zealously catholic as that of Morley $^{1}$. It was, however, after all, no recognition of presbyterian orders; it was only a patient method of getting rid of them. They were borne with for the time being, in order gradually to eliminate them. There was no scheme for their continuance in the future.

1 See p. 176. 


\section{APPENDIX B}

THE FOREIGN REFORMED CHURCHES AND THE PLEA OF NECESSITY

IT may be useful to give a conspectus of the foreign reformed churches and their respective ministries, with a view to determining how far their departure (where they have departed) from the episcopal principle was justified by the law of necessity. In this conspectus no notice is taken on the one hand of the Old Catholics, who have of course retained the principle, or on the other of the various sects, largely of English origin, which have penetrated Germany and other countries of the continent.

I. The oldest reformed or protestant body in Europe are the Waldensians. Their origin is lost in obscurity, and it would be rash to make positive statements with regard to the history of their ministry ${ }^{1}$.

1 The chief authority on the subject is Karl Müller's book Die Waldenser und ihre einzelnen Gruppen bis zum Anfang des I 4 ten Jahrhunderts (Gotha, I886). The articles by $\mathrm{H}$. Böhmer in Hauck-Herzog Realencyklopädie and by F. X. von Funk in Wetzer and Welte's (Roman Catholic) Kirchenlexicon are excellent. We may add, for the Italian Waldensians, the works of E. Comba, History of the Waldensians of Italy, and I nostri Protestanti (Firenze, 1895). 
The French Waldensians, who have given the name of their I2th century founder to the whole community, had among them three orders of ministers, corresponding to those of the church. But the French Waldensians are an extinct body, though no doubt they have left influences upon the more modern protestantism of their country.

Upon their first passing of the Alps, they were fused with a still older body of men on Italian or Lombard soil, whose origin cannot be traced. The existing Waldensian church of Italy is derived from the fusion of the two. Müller says that originally the distinction between the three offices was observed among them, as among the French Waldensians. The names of bishops and presbyters - the latter name generally translated into " seniors "-are still to be traced among them in the second half of the I5th century ${ }^{1}$. . But the same authority informs us. immediately after that " later the degrees of bishop" and presbyter ran into one, so that no distinction between them remained, and both degrees were conferred by a single act of ordination. This connexion," Müller says, "is found in the second half of the I4th century. When it came about is uncertain."

All kinds of conjectures have been formed with regard to the first beginnings of this Italian or Lombardian society and its ministry. Some have supposed that they had an episcopal succession taken over from the catholic church of the country

1 Müller Waldenser, p. I23. 
in which they lived, and with which they were on friendly terms. Some have supposed them to be descended from the little known sects of the 4th century, like the Euchites and the Paulicians. They themselves, in the $5^{\text {th }}$ century, prided themselves on being of primitive origin, anterior to the corruption which Constantine and his famous donation poured into the church. It is possible that their claim was well founded, but it cannot now be proved.

The Waldensians were chiefly known to Englishmen of the I7th and I8th centuries through the persecutions which they underwent. They were, of course, the "slaughtered saints" of Milton's sonnet. Books like that of Jean Leger and, still more, of Peter Allix, who came to this country and was made a canon of Salisbury, attracted a great deal of attention. The valleys of Piedmont became to many English people a kind of holy ground.

The present Waldensians have no episcopate, though there is a quasi-diocesan organization among them; but a vigorous and progressive section of them is favourably disposed towards episcopacy and towards a more catholic Christianity in general.

II. Next in order of seniority are the Unitas Fratrum or Moravians. Their history, in its early chapters, is curiously bound up with that of the Waldensians.

Their original home was in Bohemia. The church of Bohemia in the I5th century stood apart from the Roman communion over the question of 
receiving the blessed sacrament in both kinds. The Unitas were at first a kind of guild within this separated church ; but they came to have a great horror of everything Roman, and in $I_{467}$ they determined to seek for themselves a ministry independent of the Roman succession. After enquiries in many directions-enquiries which obtained and deserved the praise of Thorndike ${ }^{1}$ - they heard of a Waldensian elder or bishop in Austria, to whom they applied. From him they received, as they believed, a legitimate episcopal consecration untainted by anything Roman. The orders thus obtained by the Unitas have been preserved ever since, though at two periods there has been some irregularity in the transmission of their episcopate, which prevents it from being wholly satisfactory from the point of view of the ecclesiastical historian $^{2}$.

The connexion between the Unitas and the church of England has been traced by G. A. Wauer, in a little book translated under the title of The Beginnings of the Brethren's Church in England (I90I). At the restoration of Charles II, John Amos Comenius, who had visited England in I64I, made a moving appeal to the church of England on behalf of his community, then in deep affliction. Speaking of himself as "inter ultimos ultimus antistes," he commended it to us.

1 See p. 194.

2 See Report of the Committee appointed by the Archbishop of Canterbury to consider the Orders of the Unitas Fratrum or Moravians (I907). 
To you...we leave and commit, according to the example of the...divine Master...our dear mother, the church herself. Whether God will deem her worthy to be revived in her native seats, or let her die there and resuscitate her elsewhere, in either case do you, in our stead, care for her. Even in her death, which now seems to be approaching, you ought to love her, because in her life she has gone on before you for more than two centuries with examples of faith and patience ${ }^{1}$.

Comenius could not have foreseen how closely his community was destined to be associated with the church to which he commended it. Jablonsky, Wake's correspondent, was Comenius's grandson. Collections were made in England, at Wake's instance, on behalf of "the episcopal reformed churches, formerly in Bohemia, and now in Great Poland and Polish Russia." But with Zinzendorf, who received the episcopate, at one remove, from Jablonski, began the establishment of a branch of the Unitas in England. The Unitas had every wish to act in loyalty to the authorities of the church in England; but the I8th century was a time of great legal restriction in the way of religious developments, and in spite of entire goodwill on both sides, the Moravians, as they were now called, were reduced to registering themselves as dissenters, in order to obtain the protection of the law. It was all the more disappointing inasmuch as both Wake and Potter had recognized and welcomed them as a true. " protestant episcopal " church. A scheme for joint consecrations and ordinations had been prepared,

1 De Schweinitz History of the Unitas Fratrum, p. 604: 
and the apostolic Wilson had undertaken to act as superintendent or bishop of the community in this kingdom.

A more hopeful state of things has now arisen. The Lambeth Conference has revived the scheme of joint consecrations, and the Unitas has welcomed the arrangement; and there is good reason to hope that this venerable body, so rich in spiritual gifts and in missionary activity, will before long be in direct communion with the church of England, without loss of dignity to either party, and without any compromise of catholic principle.

III. We turn now to the churches whose reformation was coeval with our own, and first to those of the Lutheran confession.

(I) The church of Sweden stands alone among these churches in having preserved the apostolical succession $^{1}$. Exception to Swedish orders might perhaps be taken on the ground that the church of Sweden has no "laying on of hands" in completion of baptism, or that its priests have not previously served in a diaconate. But that there has been a personal succession of bishops unbroken from pre-reformation times to our own will hardly be questioned again. The last doubts have been removed by the researches of Dr Lundström, the present Domprost of Upsala Cathedral and Professor in the University.

${ }^{1}$ See A. Nicholson Apostolical Succession in the Church of Sweden (1880) and Vindiciae Arosienses (1887). See also The Church of England and the Church of Sweden. Report of the Commission appointed by the Archbishop of Canterbury (I9II). 
The church of Sweden had long been a reformed church before it assumed definitely the Lutheran position. It was not till I593 that it adopted the confession of Augsburg. Under Gustaf Vasa, under his sons Erik and John, it had maintained its position as an evangelical and catholic national church, without tying itself down to any formularies but its own. But under the peril of the accession of a Romanist king, Sigismund, it could no longer stand alone. Its teaching from the beginning of the reformation had been predominantly that of Luther and Melanchthon, and it was natural that, when driven to take a side among the contending parties of reformed Christendom, it should choose to put itself definitely with its nearest neighbours of the reformation and declare itself Lutheran. But it has always retained a consciousness of being something more than Lutheran, and loved to claim its continuity with the church of older days.

It is sad that it could not rather have made common cause with the church of England, from which in so large a degree it originally received its Christianity. But there was little mutual intercourse between the countries, and little mutual acquaintance between the churches. Even the Thirty Years War did not convey to England in general the knowledge of what was peculiar in the status of the church of Sweden. The church of Sweden, on its side, thought of the church of England as a Calvinistic body. The Kyrkohistorisk Arsskrift for I9I2 contains an interesting article by 
Dr Lundström which gives an account of an overture made by representatives of the church of England to the church of Sweden in I7I8. The leader in the movement was Robinson, Bishop of London, well known for his share in the treaty of Utrecht, and as the last ecclesiastic to be employed in the English diplomatic service. Robinson had been for a long time the English envoy in Sweden. He and other English divines expressed to Count Gyllenborg, the Swedish secretary of state, their concern at the progress of Romanism, especially among the princely houses of Europe. They earnestly desired that the Swedish church, as "a sister church" to their own, would enter into closer relations with that of England. They represented that the differences between the two were unimportant in comparison with the fact that both were wholly at one on the fundamental articles of faith. There was some divergence of opinion on the Lord's Supper, but they did not think it sufficient to divide the churches.

Finally they had taken Gyllenborg himself to witness how sincerely they had shown their desire for a fraternal concord between their church and ours, inasmuch as, however earnestly they opposed the toleration of the many sects in Great Britain, they favoured and protected the evangelical Lutherans in every possible way. They had further reminded him-the Bishop of London had done so in particular-of the kindness they had always had for the maintenance of our Swedish churches in Pennsylvania, where our priests and those of the English church lived together in such great and brotherly unity, that they very often preached in one another's churches, and looked after one another's congregations when the ordinary clergy were 
hindered by being away from home. But they complained on the other hand that their churches among us [i.e. in Sweden] were looked upon and treated in the same way as those of the papists, the Calvinists, and the other sects which were as far removed from them as from us. This, they added, must in the end cause an extremely mischievous coolness, not to say an open enmity. But in this way the enemies of us both gained occasion to weaken both churches. ...Among these enemies they reckoned not only the papists, but also the Calvinists, and other sects, which now for some time had been too much encouraged and permitted by the English government, to the great detriment of the English church.

Alas, the replies which Gyllenborg received from the Swedish bishops to the circular letter in which he gave them this information were far from encouraging. So far as they have been preserved, they show that the church of England was looked upon with suspicion, as a patroness of sectarian licence and of Calvinistic doctrine. Nothing came of the proposal.

The proposal is now renewed, with a less polemical aim, with fuller knowledge on both sides, and with better hopes of success.

(2) The churches of the other two Scandinavian kingdoms, Denmark and Norway, were not so fortunate. If there had been any goodwill towards episcopacy, it might have been preserved; but there appears to have been none. The bishops were chiefly looked upon as great lords, not as ministers of religion. As early as 1526 the Danish bishops practically broke with the Roman curia over money questions, and had the support of their country in 
the matter. In $\mathbf{5 3 3}$ they sent a distinct ultimatum to Rome. For the most part they had no strong objections to religious reform. The most respected of them, Ove Bilde, Bishop of Aarhus, conformed to the new order of things when it was once established, and lived in lay communion with the reformed church. Another, Knud Gyldenstjerne, who never got beyond being a bishop-elect, translated Luther's catechism into Danish. A slight pressure from the king or the rigsraad would have induced the Danish bishops to consecrate Gyldenstjerne and others without waiting for papal confirmation.

But this was far from being the wish of Christian III. No sooner had he got the mastery of his opponents, in 1536 , than he threw all the bishops and bishops-elect into prison, and only released them on condition of resigning their sees and the revenues belonging to them, and promising never again to lay claim to them ; -in the case of one or two of the younger ones, he added the condition that they should marry. Then he applied to Luther, who despatched Bugenhagen-himself only in priest's orders-to crown the new king, and to inaugurate the new ecclesiastical régime by ordaining or setting apart new superintendents or bishops in place of those who had been ejected.

From the superintendents thus set apart the present clergy of Denmark have their succession. Norway and Iceland are in the same condition. It is on record that one Icelandic bishop in the Igth century was desirous that English bishops should 
be invited to take part in his consecration-doubtless political sentiment forbade an application to the Swedes-with a view to repairing the broken succession. Martensen, then primate of the Danish church, emphatically refused, and in his sermon at the consecration denounced the idea ${ }^{1}$.

(3) In Germany, and that part of Germany which espoused the Lutheran doctrine, there was much variety of organization to begin with. The maxim cujus regio, ejus religio, naturally bore effect in a country so much broken up into small states ${ }^{2}$.

The Augsburg Confession concludes with the words :

Our meaning is not to have rule taken from the bishops; but this one thing only is requested at their hands, that they would suffer the gospel to be purely taught, and that they would relax a few observances which cannot be held without sin. But if they will remit none, let them look how they will give account to God for this, that by their obstinacy they afford cause of division and schism, which it were yet fit they should aid in avoiding ${ }^{3}$.

But in spite of this declaration episcopacy, in the old sense, became extinct in Germany. The title remained in some places ; in some the episcopal revenues remained also. There were places where the "bishopric" was held turn and turn about by a Roman Catholic and a Lutheran. The see of

${ }^{1}$ See an article in the Church Quarterly Review for April, I891, on the Loss of the Succession in Denmark.

2 A brief account of the organization of Lutheran churches will be found in T. M. Lindsay's History of the Reformation, vol. I. pp. 400 foll.

3 The translation is taken by Lindsay from Schaff. 
Osnabrück was held in this manner by more than one English prince, as a member of the house of Hanover. Why did not bishoprics remain a religious reality in the life of Germany?

It cannot be said that no bishops in Germany were favourable to reform. There was Hermann of Köln for an example. What attempt was made to obtain his help for the perpetuation of the ancient succession? Bancroft mentions several German bishops who might have proved useful for the purpose.

One Sydonius, being thrust (as it seemeth) from the bishopric of Merseburg, as cleaving wholly to popery, was afterwards, upon his leaving of the pope, and upon promise made to maintain the reformation of religion made in his absence, restored to his bishopric. And after him succeeded (as I take it in that bishopric) George the prince Anhalt,... being chosen thereunto, as he saith himself, universo capituli consens $u$, by the consent of the whole chapter ${ }^{1}$.

Any one glancing down the lists of bishops in Gams' Series will see again and again, in those parts of Germany which accepted the reformation, and in other parts also, the "resignation" of bishops in the I6th century. What became of them? What became of the bishops marked as apostata, like Erhard of Queis, Bishop of Pomesania, George of Polentz, Bishop of Samland, John of Monnichhausen, Bishop of Curland? No doubt the answer could be found; but it would probably not favour the plea of necessity set up for the broken succession in Lutheran Germany.

1 Survey of the pretended Holy Discipline, p. II7. George of Anhalt was never consecrated; but why not? 
Attempts have been made from time to time to repair the breach. It is not easy always to see why they failed. While Northern Germany was really Lutheran, there was always Lutheran Sweden to turn to. When Frederic I of Prussia failed to obtain what he wanted from the church of England, why did he not ask Jablonsky himself-who had no misgivings about his Moravian episcopate-to supply the need?

The fact is that Luther and his associates, even Melanchthon, while willing to accept episcopacy where it came easily to hand, did not think it worth any effort to secure. They had begun to ordain without bishops years before the Confession of Augsburg, and felt no scruple about it.

(4) The plea of necessity cannot be urged with much more confidence on behalf of the Swiss and French protestants.

Bingham, in his French Church's Apology for the Church of England (pp. 2I8 foll.), has an interesting passage on the subject. After dwelling at length upon the well-known history of Antonio Caraccioli, the Bishop of Troyes, who became a protestant and endeavoured to retain his see at the same time, Bingham proceeds with this summary of other cases:

The popish authors themselves tell us, there were about this time [i.e. $156 \mathrm{r}$ ] several other bishops in France, who were well wishers to the reformation, such as Odet Colinius [Coligny], Cardinal Castilion, the Admiral [Gaspar de Coligny]'s brother ; Johannes Monluc, Bishop of Valence ;

1 Odet was never consecrated. 
Sanromanus, [Arch]bishop of Aix; Johannes Barbançon, Bishop of Pamiers; Johannes de Sangelasio, Bishop of Utica [Uzès] ; Francis de Noailles, Bishop of Aquae Augustae [Dax]; Carolus Gillarius, Bishop of Chartres; together with Lewis d'Albert and Claudius Reginus, two bishops of the territory of Bern [Béarn] under the protestant Queen of Navarre.

Other instances are given by Peter du Moulin, in the preface to his translation of his father's Novelty of Popery, to which Bingham also refers. An archbishop of Vienne, a bishop of Orleans, a bishop of Meaux $^{\mathbf{1}}$, were prepared to join the protestant party; "but the great stream of the state proved too strong for them to swim against ${ }^{2}$."

But, again it must be said, the French and Swiss reformers as a rule, like the German ones, cared too little for the continuity of the historical orders to go much out of their way to secure it. They had at first no quarrel with episcopacy, as such; but they were quite contented without it. Indeed they were contented to be without any orders but such as they felt to have been conferred upon them

1 On Briçonnet, Bishop of Meaux, see H. M. Bower The Fourteen of Meaux, passim, and cp. Lindsay Reformation, vol. II. p. 14x. For further names of sympathetic bishops see Jervis Church of France, vol. I. p. II5.

2 The examples which $\mathrm{Du}$ Moulin gives in the same preface of French protestant chaplains in orders received from bishops prove to be only those of Brevint and Durel ; see above, p. 223. "And lately," he says, " a learned French divine, before he returned out of England into his country, was presented by me to the right reverend and famous Bishop of Lincoln, who conferred the holy orders upon him." This is no doubt the case of Du Moulin's relative, Pierre Jurieu. Why did none of these learned foreigners carry back with them the highest order? 
by the direct calling of God. Calvin, as has been already mentioned, was never ordained by any one, except, as a boy, to the subdiaconate; Beza was never ordained at all. Ordinations conferred by these men cannot be called presbyterian orders; and all the arguments derived by Field or Mason from the identity of presbyters and bishops fall to the ground, unless it can be shown that the ordaining hands were at any rate those of presbyters. This would be difficult to show in the case of the Calvinistic churches of France and Switzerland, and perhaps of Holland also. They may perhaps be upheld on other grounds, but not on that of an inherent power of catholic presbyters to ordain ${ }^{\mathbf{1}}$.

(5) In the case of Calvinistic Scotland, the plea of necessity is, of course, wholly out of place. Scotland became dogmatically presbyterian. And here perhaps the argument from the identity of bishops and presbyters may with more force be urged. Though it seems uncertain whether John Knox was ever ordained priest ${ }^{2}$, and though others

1 There were bishops in other parts of Europe who joined the reformation, like Vergerius. Dixon History of Church of England, vol. III. p. 235, adopts the belief that John a Lasco was a bishop.

2 The article on him in Dict. Nat. Biogr. shows that he received minor orders, and it quotes a Roman Catholic contemporary as saying that he "contrived to be made a presbyter"; but whether that means such a presbyter as the Roman Catholic writer himself acknowledged or not is not clear. As he was made a chaplain to Edward VI, he may perhaps be added to the list of those who have been allowed to minister in the church of England without being ordained by bishops. Lindsay Reformation, vol. II. p. 285, says that he was in priest's orders in I540. Grub's account seems somewhat inconsistent. He says (Eccl. Hist. of Scotland, vol. II. p. 3I) 
who held office with him in the reformed church of Scotland were in the same position ${ }^{1}$, yet it can hardly be doubted that most of those who founded the presbyterian system in Scotland were themselves presbyters, and the succession has, no doubt, been maintained, and even jealously insisted upon.

that Knox was ordained priest at about the age of 25; yet on the next page complains that at his call to minister to a congregation he received no imposition of hands.

1 See the editor's note in Keith's History, vol. IIr. p. I3 (ed. I850), and Grub, vol. II. p. I8I. 


\section{APPENDIX C}

ORDINATION AMONG THE NONCONFORMISTS OF ENGLAND

IT is frequently asserted by controversialists that logically the ministers of the various English nonconformist bodies stand on the same footing as the ministers "beyond the seas," for the validity of whose orders English churchmen have sometimes earnestly contended. Nothing disrespectful to the nonconformist ministries is meant by what we have to say in this Appendix; but for two reasons at least it is necessary to demur to the view thus expressed. In the first place the English nonconformist bodies, however noble in many ways their history is, do not occupy the same position as the reformed churches of the continent. Even if it be allowed that they were justified in separating from the reformed church of England, they would not themselves contend, nor would any one of them contend, that they represent the ancient national Christianity of England in the same way as the protestant churches of Denmark or of Switzerland represent the historic Christianity of their respective countries. They represent sectional interests at most. And in 
the second place it is a mistake to class them all together for the purpose now in view. Their original tenets with regard to "ministering in the congregation" differ widely from each other, though there is a tendency to converge ; and the various ministries themselves have had very dissimilar histories.

The reader would be well advised to study three articles in the back numbers of the Church Quarterly Review, which throw the light of true historical knowledge upon this question. The first is in vol. xIV. (April, I882), Not Nonconformists, but Dissenters. The second is in vol. XIX. (October, I884), Ordination, Nonconformity, and Separatism. The third is in vol. xxxI. (January, I89I), The Anglican Ordinal and Non-episcopal Ordination. Perhaps nowhere within so brief a compass is it possible to find so much illumination on the principles concerned.

(I) In theory the presbyterian conception of orders, imported from Geneva by way of Scotland, does not differ radically from that which has prevailed in the universal church. It only differs from it in respect of the officers empowered to ordain. This is, of course, a most important difference in practice; nevertheless the idea of the ordination in itself is not necessarily changed by entrusting it to presbyters instead of bishops. Many presbyterian divines have enforced the doctrine of the apostolical succession as urgently as episcopalians. It is understood that the laying on of the hands of the presbytery represents a solemn commission from the church universal, in the name of which the presbytery act. The power 
which they exercise is not wholly derived by delegation from the particular church for whom the minister to be ordained is intended. It comes from the whole historic Christianity of all generations. It is continuous with the authoritative ministry of the early church. Its source is in the commission given by our Lord to his first disciples and in the first inspiration with which he endowed them for their work. It stands for continuity, for the principle of order, for unity among the Christian churches.

Most of the first English presbyterians were in the strict sense " nonconformists," like Baxter. They had no intention of becoming "separatists," or founding a church apart from the episcopal church of England. Even when they began to ordain after the restoration-thefirst presbyterian ordination after that date took place in 1672 - they regarded it only as a temporary expedient. Baxter, writing in 1679 , said that they did it "pro tempore, until God shall give them opportunity to serve him in the established way, it being reformed, and well ordered parish churches which are most agreeable to their desires ${ }^{1}$." Many presbyterian ministers went on ministering for many years without having received any ordination at all.

But this attitude was not very long continued. It became clear that presbyteral ordination was not going to be recognized in the church of England, and those who clung to it were obliged to choose between the two alternatives. A large proportion of them

1 The Nonconformists' Plea, p. 246. 
drifted into the separatist position. They even came to associate with themselves in the act of ordination the men who had been their most determined foes, the independents. The difference in principle, however, between these co-operating parties could hardly be concealed. Stoughton records an ordination in I689, which was intended to have been a joint ordination by presbyterians and independents, where the conflict became acute ${ }^{1}$. The incongruity was still noticeable even at a later time ${ }^{2}$.

(2) The independent, and we may add the baptist, conception of ordination was originally as different from that of the presbyterians as was their relation to the church of England. "Come out of her, my people," was the text which expressed their view of the church; and they had no feeling for connexion with past history, and no feeling for religious authority, to express in their ordinations. The only authority called into action was the authority of the congregation which elected the man to minister to them. The other ministers, who took part in the service, assumed no authority, and no responsibility. "No examination by the ordainers took place.... The neighbouring ministers merely recognize their brother ${ }^{3}$." If an imposition of hands took place, which appears to have been not invariably the case, it was not supposed to convey authority;

i Religion in England, vol. v. p. 284.

${ }^{2}$ C. Q.R. October, $\mathrm{I} 884$, p. 44.

$3 \mathrm{~T}$. S. James History of Litigation and Legislation respecting Presbyterian Chapels, p. 804; quoted in C.Q.R. ut supra. 
it was not supposed to convey grace. It was only an outward token of acknowledgement and of good will.

The "Declaration of Faith, Church Order, and Discipline," under which the congregational churches are now governed, says that

they believe that church officers, whether bishops or deacons, should be chosen by the free voice of the church [i.e. the local church]; but that their dedication to the duties of their office should take place with special prayer, and by solemn designation, to which most of the churches add the imposition of hands by those already in office ${ }^{1}$.

(3) There is no need to speak of the Society of Friends-one of the most effective agencies for good that Christendom has ever seen. They have no ministry, and no ordination. It only remains to mention the Methodists.

It seems to be carelessly assumed by some people that the methodist ministry springs from Wesley, and has therefore at least a presbyteral value. This is not the case, except with the "episcopal" methodists of America, who spring from Coke and Asbury, acting on the commission which John Wesley gave them to be "superintendents" of the society in the United States. Although Wesley on several occasions at the end of his life ordained some of his preachers, he inaugurated no system of ordination among them. As is well known, he earnestly wished the society never to separate from the church, however little

1 This last was a concession to presbyterianism. See Stoughton, vol. v. p. 294. 
heedful he was of the means to secure that end. It was not until the presidency of Jabez Bunting in 1836, that the methodists began to ordain. Ever since I795, four years after the founder's death, the preachers had resumed the practice of administering the sacraments in their chapels, - a practice which had begun long before, without any authorization, but had been stopped by the conference of I755. But the theory which governed their practice, if theory there was, amounted to this, that men called by the providence of God to preach the gospel are empowered, indeed compelled, to give the sacraments where they cannot be obtained under proper conditions in the church. Thoughts of fuller union, or reunion, with the church were still in the air. But that union was not destined to take place then. Bunting was the man who did away with the halfand-half position. "He completed the detachment of methodism from its Anglican base; he found it a society and consolidated it into a church ${ }^{\mathbf{1}}$."

Bunting does not seem ever to have received any kind of ordination, and no succession which originates with him can claim to have any ecclesiastical value. Its merits have to be looked for in other directions.

The same observations will apply to the ministries of the offshoots from Wesleyan methodism.

1 Dict. of Nat. Biogr., Bunting, Jabez. 


\section{APPENDIX D}

\section{SCHISM AND COMMUNION}

THE church of England has been compelled by her position to devote a great deal of attention to the subject of schism, and it would require a large volume to give an adequate account of the many treatises which have cleared her from the charge of schism in relation to Rome, or condemned the protestant dissenters who have left her. The tone and temper of these treatises have varied greatly. John Hales moves in a different world of thought from Henry Hammond. Sherlock and Stillingfleet do not contemplate quite the same situation as Bennett or Daubeny. But all of them have at bottom the same ideal, of a single organization, in which all Christians ought to be able to communicate together, neither giving nor taking offence over matters which do not immediately involve the salvation or loss of souls. In loyalty to ancient catholic principle, they have been unable to acquiesce in the existence of more than one Christian body in one locality, except possibly as a temporary arrangement, with a view to a more complete union. 


\section{AUTHORITATIVE DOCUMENTS OF THE CHURCH}

The teaching of the church of England as a whole on this subject has been not obscurely expressed at more than one period since the work of reformation began.

The constitutions and canons ecclesiastical of I603 speak thus :

9. Authors of Schisms in the Church of England censured.

Whosoever shall hereafter separate themselves from the communion of saints, as it is approved by the apostles' rules, in the church of England, and combine themselves together in a new brotherhood, accounting the Christians who are conformable to the doctrine, government, rites, and ceremonies of the church of England to be profane and unmeet for them to join with in Christian profession, let them be excommunicated ipso facto, and not restored but by the archbishop, after their repentance and public revocation of such their wicked errors.

\section{Io. Maintainers of Schismatics in the Church of England} censured.

Whosoever shall affirm that such ministers as refuse to subscribe to the form and manner of God's worship in the church of England, prescribed in the communion book, and their adherents, may truly take unto them the name of another church, not established by law, and dare presume to publish it, that this their pretended church hath of long time groaned under the burden of certain grievances imposed upon it and upon the members thereof before mentioned by the church of England and the orders and constitutions therein by law established; let them be excommunicated, and not restored until they repent and publicly revoke such their wicked errors. 
II. Maintainers of Conventicles censured.

Whosoever shall hereafter affirm that there are within this realm other meetings, assemblies, or congregations of the king's born subjects than such as by the laws of this land are held and allowed, which may rightly challenge to themselves the name of true and lawful churches; let him be excommunicated, and not restored but by the archbishop, after his repentance and public revocation of such his wicked errors.

It is, of course, to be noted that when these schisms are spoken of as being "in the church of England," the reason is that at the time of composition all baptized Englishmen were considered to be a single church. A schism from the church is therefore a schism in it. It may also be observed that when the laws of this land at last allowed other meetings to be held than those of the church of England, such toleration did not remove the ecclesiastical objection to them, or do away their schismatic character from a religious point of view.

The twenty-seventh canon is headed

Schismatics not to be admitted to the Communion.

It runs :

No minister, when he celebrateth the communion shall willingly administer the same to any but to such as kneel, under pain of suspension, nor under the like pain to any that refuse to be present at public prayers according to the orders of the church of England, nor to any that are common and notorious depravers of the book of common prayer and administration of the sacraments,... except every such person shall first acknowledge to the minister, before the churchwardens, his repentance for the same, and promise by word, if he cannot write, that he will do so no more.... 
It must appear strange that any one who could "deprave" the church of England and its ways should be thought likely to present himself for communion in it. But the reason is obvious. No one was allowed by law to hold any office in the kingdom unless he was in communion with the established church. Horrible, therefore, as the profanation was, candidates for a mayoralty or any similar position came to the communion to qualify, if their consciences were elastic enough to permit them, although they might denounce the established church as a synagogue of Satan, and deride her ceremonies as rags of Rome. The canon of $\mathrm{I} 603$ discloses the mind of the church on this matter. So far was the church from liking and approving the system which made such indecencies possible, that sentence of suspension was passed upon any minister who should abet them by giving the communion to "occasional conformists" of this type. It was not the church of England which urged men to come to her altars whether they believed her doctrine or not.

Practically the last time that the church of England was allowed by state authorities to speak with a collective voice, before it was silenced for I50 years, that voice was raised to insist upon the sinfulness of schism. Bishop Fleetwood said in I7I2 that when men returned from schism to the communion of the English church, they were not required to make confession of their errors. He had probably forgotten the canons of 1603 . As a matter 
of fact they had probably been seldom acted upon. No form had been provided for carrying out the instructions of the canons. But two years after Fleetwood wrote those words, the church made good the omission. Convocation drew up a form for the reconciliation of penitents returning from Rome or from " the separation."

It is in many ways a beautiful office. The lesson is that of the joy of the Shepherd for the recovery of the lost sheep. "If the penitent comes from the separation," then the " hymn " to be used is Psalm cxxii., "I was glad when they said unto me: we will go into the house of the Lord." The bishop or priest who admits examines the penitent whether he accepts the sufficiency of the scriptures and believes the apostles' creed. On his assent, the bishop or priest proceeds :

Art thou truly sorrowful that thou hast not followed the way prescribed in these scriptures for the directing of the faith and practice of a true disciple of Christ Jesus ?

Answer. I am heartily sorry, and I hope for mercy through Jesus Christ.

He asks further :

"Dost thou allow and approve of the orders of bishops, priests, and deacons" - -adding, if the penitent has been a teacher in some separate congregation, "as what have been in the church of Christ from the time of the apostlesand wilt thou as much as in thee lieth, promote all due regard to the same good order and government of the church of Christ?" 
If the penitent be one who has relapsed, he is to be asked :

Art thou heartily sorry that when thou wast in the way of truth, thou didst so little watch over thy own heart, as to suffer thyself to be led away with the shows of vain doctrine? and dost thou steadfastly purpose to be more careful for the future, and to persevere in that holy profession, which thou hast now made?

To which a humble and suitable reply is made, followed by absolution, prayers, and final exhortation ${ }^{1}$.

\section{OPINIONS OF DIVINES}

The sin of schism may be approached from various sides. It may be considered from the ethical point of view. The sinfulness of it may be held to consist in the want of charity, breaking up the unity which heavenly love would form. This was characteristically the line taken by St Augustine and by John Hales. Or, without excluding the consideration of charity, its chief sinfulness may be thought to consist in want of obedience to constituted rule and authority. This is perhaps the more usual way of regarding it. It is the way of St Cyprian and of Henry Dodwell.

Or it may be approached in the more matter of fact way of considering what acts constitute it. Here it may be chiefly looked at as a negative thing. Abstinence from church services, the forsaking of the assembling together, refusal to take part in the corporate life of the church, may be viewed as

1 See Cardwell Synodalia, vol. ir. pp. 796 foll. 
schismatic. It has sometimes been asserted that this negative aspect was the only one which really concerned the great divines of the Caroline age : they only complained that men would not come to the communion of the church. The assertion will not bear examination. Schism was, or might advance into being, a positive thing also. It might and did express itself in distinct acts, and, naturally, the more it thus expressed itself, the more flagrant it was thought.

The acts which constituted schism were such as these. To gather people together for the purpose of worshipping apart from the church, for joining in unauthorized devotions, for receiving instruction and exhortation from unauthorized teachers, was plainly schismatic. The Five Mile Act of 1665 and the Conventicle Act of 1670 were not acts of the church : their object was political, not religious; but they sufficiently illustrate the prevailing views. The Five Mile Act complains that people " have settled themselves in divers corporations ${ }^{1}$ in England, sometimes three or more of them in a place, thereby taking an opportunity to distil the poisonous principles of schism and rebellion." The Conventicle Act makes it penal for any one over sixteen years of age to be " present at any assembly, conventicle, or meeting, under colour or pretence of any exercise of religion in other manner than according to the liturgy and practice of the church of England." Such conventicle

1 "Corporations" here mean the corporate boroughs where they settled, not the schismatic bodies. 
was defined as an assembly at which " there shall be five persons or more assembled together, over and besides those of the same household, if it be in a house where there is a family inhabiting," or, if it be elsewhere, "then where any five persons or more are so assembled as aforesaid."

To assemble but once in this fashion was an act of schism; to continue to do so was of course to become habitually schismatic. When the persons so joining formed themselves into incorporated societies, when those societies entered into league with similar societies in other places, when they assumed the name of churches, local or diffused, the schism was more pronounced. If they undertook to administer the sacrament in these assemblies, then, from the point of view of the church, they came directly under the Cyprianic condemnation of those who erected " altar against altar." This was far more heinous in church eyes than the fortuitous gatherings for extempore prayers and preaching. And when they added to this the definite setting apart of ministers and a line of ministers of their own, the schism was complete. All remains of union with the church considered as a visible society were destroyed. There might perhaps remain inward ties, of common beliefs, and even of mutual regard; but the outward bond was gone. "Ordination is separation," was the unchallenged verdict of Lord Mansfield. It was in order to avoid any semblance of such separation that the Moravians on settling in England were anxious to establish the system of joint ordinations. 
That schism was sinful was held by all churchmen, and by most dissenters. But it was always a question, on whose shoulders the sin lay. Church writers readily admitted that there was a state of schism between the church of England and the church of Rome, and where there is schism there is sin. But they maintained that the sin was Rome's. Rome, as Jewel affirmed, had cast us off, through no fault of ours. Even if we had renounced Rome, we were justified in doing so, nay, were compelled to do so; because the only terms on which we could retain communion with Rome were sinful terms. Where sinful terms of communion are imposed, a Christian, or a Christian church, is bound to refuse communion, and the guilt of the consequent schism attaches to those who insist upon such terms. In the case of the protestant dissenters the whole argument turned upon the point whether the terms of communion with the church of England were or were not sinful. Church writers were ready to admit that if they were thought to be sinful, those who thought so were bound in foro conscientiae to secede; but if they did not think so, they were bound by the laws of scriptural and primitive Christianity to put preferences aside and communicate with the church. Otherwise they were guilty of schism.

At this point comes in the controversy over " occasional conformity."

The fiercest assailants of occasional conformity were the dissenters. They objected, not on the ground that for a dissenter to communicate with the 
church of England was disloyal to his dissenting church. If the church of England had been a less corrupt and degraded church, something might be said for communicating with it. But so hopelessly bad and unspiritual was the whole position of the church of England that to communicate with it was as bad as communicating with Rome. Defoe, in I697, put forth his Enquiry into the Occasional, Conformity of Dissenters, in which he described the practice as halting between God and Baal. He affirmed that none but Christians of an amphibious nature could believe one way and worship another. The churchman and the dissenter, he said, held " two religions."

The persons thus attacked were, of course, chiefly nonconformists, and not separatists. Howe, whom Defoe singled out for his attack, replied. He contended that if occasional conformity to some other communion was a fault, it was not a fault that ought to exclude a person from his own. Baxter called it " a healing custom." Calamy thought it an indispensable duty. Humphrey wrote to a friend

Our moderate nonconformist presbyterians are for their stated communions with the congregations whereof they are pastors or members ${ }^{1}$; but they will join in their parish churches for occasional communion, or else they think themselves to be guilty of schism. Thus Dr Bates does sometime in the year receive the sacrament in his parish, and $\mathrm{Mr}$ Baxter did often in the parish where $\mathrm{I}$ am. But as for myself, I declare my stated communion to be with the

1 Baxter, however, seems not to have followed this rule; see above, p. 279. 
church,...and my occasional communion with the nonconformist meetings, where I go sometimes and sometimes am called to preach. In short, I am a nonconformist minister, but a conforming parishioner, and I know nobody ...that is offended at it.... Ask your minister, when you were baptized, into what church was it? whether it was not into the church universal? Ask him then, whether that which gives a man right to be a member of the universal church does not give him right of occasional communion with all true churches that are but parts of it ${ }^{1}$.

The spirit revealed in these words, and in the practice referred to, is an attractive spirit, very different from the scorn and hatred shown by the early separatists. There were many churchmen who warmly welcomed this attitude, though they were not satisfied with it. It was better that the nonconformist, or the separatist either, should come sometimes to church and to the communion table than that he should never come at all, but should turn his back on both with abhorrence. If he came once a year, or once in two years, he could not feel so bitterly hostile to the church after all. Perhaps before long he might be induced to come oftener, to come regularly, to come to church and go nowhere else. It was a confession that there was nothing wrong in coming to church. It was a confession that the church imposed no sinful conditions of communion. Churchmen seized upon the admission and urged it vigorously. It must not be supposed that they condoned the schismatic communions because of the

1 Quoted by Abbey and Overton English Church in the Eighteenth Century, vol. I. p. 427. For many instances to the same effect, see Williams' Case of Lay Communion in London Cases, p. 65. 
occasional communion in the church; still less that they regarded the dissenting societies in the same light as Humphrey regarded the church of England, as "true churches" forming "parts" of the universal church. But they caught at this occasional conformity as the best that could be had for the moment, and hoped for what it might lead on to.

This is for the most part the animus of those tracts which were gathered together and published in the volume known as the London Cases ${ }^{1}$. A good example may be taken from the tract written by Tenison, then not yet bishop. The style is homely and good-humoured.

Do as much as you can do. Do as much as the dissenters who are most eminent for learning, piety, preaching, writing, experience, and fame, sometimes actually do. They have owned our communion to be lawful. They have received the communion kneeling. They have bred up children to the ministry of this church. They have joined in the liturgy.... Do as the ancient nonconformists did, who would not separate, though they feared to subscribe; who wrote with such zeal against those of the separation that Mr Hildersham was called "the Maul of the Brownists."

Do more for the peace of God's church than for a vote, or office, or fear of legal penalty. Come as Christians to the sacrament, and not as politicians. Those who have done so [and] yet break the unity of the church, are said to use the arts of Jesuits, and to be without all excuse, by a dissenter, who writes with commendable temper....

1 A Collection of Cases and other Discourses lately written to recover Dissenters to the Communion of the Church of England, by some Divines of the City of London. Third edition. 1698.

M. 
For peace sake, let that be more constant, in which your conscience alloweth occasional exercise. A member who joins himself to any established church, and also to any churches which are set up, not as legal supplements of it but as forts against it, seems to be a kind of wooden leg, if I may represent so grave a matter by so light a similitude. $\mathrm{He}$ is tied on and taken off at pleasure; he is not as by natural ligaments and nerves knit to such ecclesiastical bodies. If all would do constantly what they can in conscience do sometimes, they would create a better opinion of themselves... and hinder all the destructive breaches amongst us ${ }^{1}$.

\section{The learned Cave presses the argument from con- sistency :}

We beg that those who by their conformity have declared that they can close with our communion would still continue in the communion of our church. This is a request so reasonable, that I hope it cannot fairly be denied. Whatever dissatisfactions others may allege to keep them at a distance from us, these men can have nothing to pretend, having actually showed that they can do it. For I am not willing to think that herein such men acted against their consciences, or did it merely to secure a gainful office or a place of trust, or to escape the lash and penalty of the law. These are ends so very vile and sordid, so horrible a prostitution of the holy sacrament, the most venerable mystery of our religion, so deliberate a way of sinning, even in the most solemn acts of worship, that I can hardly suspect any should be guilty of it, but men of profligate and atheistical minds, who have put off all sense of God, and banished all reverence of religion. I would fain believe that when any of our brethren receive the sacrament with us, they are fully persuaded of the lawfulness of it, and that the

1 T. Tenison Argument for Union (I683), pp. 4I foll.; London Cases, 3rd ed., p. 493. 


\section{Appendix $D$}

principle that brings them there is the conscience of their duty. But then I know not how to answer it, why the same principle that brings them thither at one time should not bring them also at another, and that we should never have their company at that solemn and sacred ordinance but when the fear of some temporal punishment or the prospect of some secular advantage prompts them to it.... I beseech our dissenting or rather inconstant brethren to reason a little. If our communion be sinful, why did they enter into it? If it be lawful, why do they forsake it ${ }^{1}$ ?

Cave clearly regards the act of communion as " entering" the body communicated with, and as clearly regards the returning to another body as " forsaking " it.

Grove, afterwards Bishop of Chichester, speaks in the same manner. $\mathrm{He}$ is encouraged by the numbers of former dissenters who have lately joined in the holy communion in London churches.

Those that are already come in will not stand in need of any further persuasion, but only that they would continue constant in that communion they have now embraced. For if they should leave us again, and return to their separate assemblies, they would seem by this to condemn themselves. For if it were lawful for them to communicate with us once, it must be lawful for them to do so still ; and they will not refuse to submit to authority in all things that may lawfully be done. I cannot therefore see how they can avoid being self-condemned, if they should forsake our communion ; for if they judged it unlawful, they sinned wilfully when they entered into it ; if they think it lawful, they would then sin in withdrawing from it ${ }^{2}$.

\section{London Cases, p. 50r.}

2 London Cases, p. 2. Cp. Sharp's Discourse of Conscience, ibid. p. 159. 
William Sherlock goes beyond Grove or Tenison in his disapprobation of playing fast and loose with communion. In his Resolution of some cases of Conscience which respect Church Communion, he sets the matter forth in a very lucid manner. Defining the church as " a body or society of men, separated from the rest of the world, and united to God and to themselves by a divine covenant," he teaches that church communion does not consist entirely in personal and presential communion in religious offices. It is "something antecedent to all the acts and offices of communion."

Now should any man who is no member of the church, nor owns himself to be so, intrude into the church, and communicate in all holy offices, this can be no more called an act of communion than it can be said to make him a member of the church of which he is no member, and resolved not to be. Prayers and receiving the sacraments, etc., are acts of communion when performed by church members in the communion of the church; but they are no acts of communion when performed by those who are no church members, though, to serve a turn, they thrust themselves into the society of the church. As for instance, suppose a member of a presbyterian or independent conventicle should, for reasons best known to himself, come to his parish church... and receive the Lord's supper,... does this make this man a member of the church of England, with which he never communicated before and, it is likely, will never do again ? If it does not, all this is no act of communion, which can be only between the members of the same body.

"Since the decay of church discipline," such 
things may sometimes be done by those who are not members; but this

is such an abuse, as would not have been allowed in the primitive church, who denied the communion to schismatics, as well as to the excommunicate upon other accounts'.

Sherlock shows very plainly the impossibility, on primitive and scripture principles, of two churches in the same place.

Churches at a distance may be distinct churches, under their distinct bishops, but yet in the same communion; but distinct churches in the same place can never be of the same communion, for then they would naturally unite and cement into one. There must either be antibishops, or schismatical presbyters, set up in opposition to their bishops, under different and opposite rules of worship and discipline; which makes them rival and opposite churches, not members of each other. From hence I think it plainly appears that all separation from a church wherein we live, unless there be necessary reasons for it, is schism.... This has often made me wonder, what those men mean, who take all occasions to quarrel at our constitution, and assign a great many reasons why they cannot communicate with us, and yet at the same time will not own that they have made any separation from us. What middle state now shall we find for these men, who will neither continue in the church, nor allow themselves to be out of it?...For two churches to renounce each other's communion, or at least to withdraw ordinary communion from each other, from a professed dislike, and yet still to continue in a state of communion with one another, is a downright contradiction. To be in communion is to be members of the same body and society; he that can prove and he 
that can believe two opposite societies, founded upon contrary principles, and acting by contrary rules, and pursuing contrary ends, to the ruin and subversion of each other, to be the same body and the same society, are very wonderful men to $\mathrm{me}^{\mathbf{1}}$.

Sherlock passes on to occasional communion. To him this is a contradiction in terms :

This [i.e. what is meant by fixed or constant and by occasional communion] is a question which would grievously have puzzled St Cyprian and St Austin and other ancient fathers, who never heard but of one sort of communion. For indeed there is no place for this distinction...according to the principles of catholic communion. To be in communion with the church is to be a member of the church; and I take it for granted that a member signifies a fixed and constant, not an occasional member,-not a member which is one day a member, and the next day, upon his own voluntary choice, is no member.... It is as plain a contradiction to talk of an occasional act of communion, as of occasional membership ${ }^{2}$.

We might talk of occasional communion with the church in a place where we are travelling, and of constant communion with the church of the place where we live; but this is a wholly different thing from what the dissenter claims to do when he comes to the church communion.

For in the first case we only communicate with such churches which are, all in communion with each other, and therefore he who is a member of one is a member of them all, and communicates with them wherever he is, as a member. But he who is a fixed member of a presbyterian or independent church cannot communicate so much as

1 London Cases, p. 25.

2 Ibid. p. 26. 


\section{Appendix D}

occasionally with the church of England as a member, because he is a member not only of another particular, but of a separate church ; and it is impossible for any man who is one with himself to be a member of two separate churches; and whatever acts of worship we join in with other churches, of which we are no members, they are not properly acts of communion ${ }^{1}$.

Sherlock is not blind, if he is a little ironical, towards the good intention of the occasional communicant. He deals with it in the same way as Tenison and Grove :

In this divided state of the church there are a great many among us who think they cannot maintain constant communion with the church of England, as constant and fixed members, who yet upon some occasions think they may communicate with us in all parts of our worship, and actually do so. Now when these men who are fixed members, as they call it, of separate churches, think fit to communicate in all parts of worship with the church of England, we charitably suppose that men who pretend to so much tenderness of conscience and care of their souls will do nothing, not so much as once, which they believe or suspect to be sinful at the time when they do it; and therefore we conclude that those who communicate occasionally with the church of England do thereby declare that they believe there is nothing sinful in our communion; and we thank them for this good opinion they express of our church, and earnestly desire to know how they can justify their ordinary separation from such a church as requires no sinful terms of communion. If anything less than sinful terms of communion can justify a separation, then there can be no end of separations, and catholic communion is an impossible and impracticable notion ${ }^{2}$. 
Finally Sherlock passes on to the question " whether it be lawful to communicate with two distinct and separate churches." The number can hardly have been great, but he shows that there were already some liberal minded churchmen who thought it lawful, not only for dissenters to do it, but for themselves likewise to do it in return.

This is thought of late days not only a very innocent and lawful thing, but the true catholic spirit and catholic communion to communicate with churches of all communions, unless perhaps they may except the papists and quakers. It is thought a schismatical principle to refuse to communicate with those churches which withdraw communion from us. And thus some who communicate ordinarily with the church of England make no scruple to communicate in prayers and sacraments with presbyterian and independent churches; and presbyterians can communicate with the church of England and with independents, whom formerly they charged with downright schism; and some think it very indifferent whom they communicate with, and therefore take their turns in all. But this is as contrary to all the principles of church communion as anything can possibly be. To be in communion with the church is to be a member of it; and to be a member of two separate and opposite churches is to be as contrary to ourselves as those separate churches are to each other. Christ hath but one church and one body, and therefore where there are two churches divided from each other by separate communions, there is a schism and rent in the body; and whoever communicates with both these churches, on one side or other communicates in a schism². 
Sherlock is aware that his argument will only weigh with those who retain something of the catholic conception of the church :

Now if schism be an innocent thing, and the true catholic spirit, I have no more to say, but that the whole Christian church ever since the apostles' times has been in a very great mistake; but if schism be a very great sin, and that which will damn us as soon as adultery and murder, then it must needs be a dangerous thing to communicate with schismatics. The sum of all in short is this. Besides those men who justify their separation from the church of England by charging her with requiring sinful terms of communion (which is the only thing that can justify their separation, if it could be proved), there are others who separate lightly and wantonly, for want of a due sense of the nature of church communion and our obligations to preserve the unity of the spirit in the bond of peace. They have no notion at all of a church, or no notion of one church, or know not wherein the unity and communion of this church consists ; and these men think it is indifferent whether they communicate with any church at all, or that they secure themselves from schism by communicating sometimes with one church and sometimes with another; that they may choose their church according to their own fancies, and change again whenever their humour alters...

So Sherlock concludes with an earnest appeal to deal with the question in a less frivolous spirit.

In $A$ Letter to Anonymus, who had criticized his Church Communion, Sherlock deals with some further points :

What now is all this to me? I don't charge our dissenters with schism from [i.e. because of] the invalidity of their orders, but for their causeless and sinful separation 
Let us suppose that they have no need of any orders, or that such orders as they have are good, or that they had episcopal orders and were governed by bishops of their own, as the Donatists were, yet they would be never the less schismatics for that, while they separate from the church of England and from each other. If orders be necessary, and they have no orders, then they are no churches at all; if they have true orders, and are true churches, but yet divide Christian communion by separating from any sound part of the Christian church, they are schismatics ${ }^{1}$.

1 London Cases, p. 40. For a very direct, if brief, condemnation of the practice referred to, see the end of Benjamin Calamy's Considerations about the Case of Scandal, ibid. p. 240: "Such a kind of conformity as some practise, and call 'occasional communion,' which is coming to church and sacrament to serve a turn, is truly scandalous to all good men, of what persuasion soever." 


\section{INDEX}

Act I3 Elizabeth cap. I2, 8o, $229,285,489,508$

Act of Uniformity, I77, 278, 368,509

Aerius, his "heresy" on episcopacy, 28, 30, 38, 39, 4I, 46, 5I, 58, 9I, 96, 97, IOI, I09, I32, I39, I46, I8I, 220, 240, $245,246,249,355$

Andrewes, on the jus divinum of bishops, 66; on the foreign churches, 70 ; at consecration of Scotch bishops in I610, 70 foll.; referred to, $80, I_{15}$, 147

Anglicanism, its special characteristics, I foll., I 7, I68; (Hooker) Io, (Bramhall) I9, 203, 207 foll., (Bull) 20, (Saravia) 44 , (Andrewes) 70, (Mason) 87 foll., (Crakanthorp) 95, (Carleton) 107, (Taylor) 128, I3I, (Laud) 146 foll., (Mead) 157, (Ferne) I6I, (Clarendon) I 73 foll., (Thorndike) I 89 foll., (Gauden) 196, (Cosin) 221, 23I, (Parker) 255, (Puller) 263 foll., (Jane) 286, (Comber) 292, (Beveridge) 296, (Cave) 300, (Burnet) 314 foll., (Hickes) 321 foll., (Nichols) 358, (Bingham) 367, (Maddox) 400, (Daubeny) 4I 7, (Van Mildert) 427, 43I, (Heber) 436 foll., (Skelton) 438, (Knox) 44I, (Jebb) 444, 445 foll., (Lightfoot) $48 \mathrm{I}$

Antiquity, the appeal to, I foll.
Bancroft, on episcopacy, 45 foll. ; consecrates the Scotch bishops, 72

Barrington, Shute, 426

Barrow, Isaac, 244 foll.

Baxter, I21, 213 foll., 233, 266, $279,283,367,543$

Beveridge, anecdote of, 287 ; on lay prebendaries, 288 ; against hypothetical reordinations, 288 ; on apostolical succession, 294 foll.: on dissenting ministries, 296; admits none but episcopal ordination, 297

Beza, I6, 29, 4I, 44, 46, I55, 485,526

Bilson, 47 foll.

Bingham, his Antiquities, 363 foll. ; his French Church, 366 foll.

Bishops, a distinct order from presbyters, affirmed by Hutton, 30 ; by Sutcliffe, 40 ; by Hooker, 6o; by Andrewes, 66, 67; by Forbes, I03; by Hall, II 5 ; by Taylor, I 26 ; by Laud, 147; by Cosin, 219 (but cp. 225); by Pearson, 237; by Prideaux, 319 ; by Dodwell, 334 ; by Sherlock, 34I foll. ; hy Bingham, 363 ; by Burnet, 402 ; by Maddox, 402; denied by Field, $6 x$ foll. ; by Mason, 9I foll.; by Usher, I 20,122 ; by Mead, I56; by Wesley, 407; the question dismissed by Davenant, I08 ; by Ferne, I63; by Cave, 299 
Bohemian Brethren, see Unitas Fratrum

Bramhall, his catholicism, I9, 203 ; influenced by Ward, II8; large-mindedness, I69, 203, 206 ; on episcopacy, 204 foll. ; on relation to Rome, 207; dissociates himself from protestantism in general, 209 foll. ; on Scotch presbyterianism, 2 I 2 foll. ; on communion with foreign protestants, 2I3 ; on succession among them, 2I5; reordains presbyterian ministers, 2I7; his letters of orders a precedent, 290

Brett, 327 foll.

Bull, his catholicism, 20

Burnet, on the Act of I 3 Eliz., 80,490 ; on Leighton, 274 ; on the comprehension scheme, $285,286,288$; his defence of Anglican orders, $3^{\text {I } 2}$ foll. ; his Articles, $3 \mathrm{I} 5$ foll. ; on the changes in the ordinal, 319; quoted with approval by Hickes, 327 ; by Maddox, 402

Canons of I 57 I, 9

Canons of 1603, 16, 207, 264, 326,535

Carleton, George, I05 foll.

Cave, 299, 546

Charles I, I42, I67 foll., 308, 340

Chillingworth, I54

Churches, the foreign reformed, their relations with the church of England, (Saravia) 33 foll. 42 ; (Hooker) 53 ; (Andrewes) 70 ; (Bancroft) 72 ; (Overall) 79 ; (Mason) 8I, 88, 9I foll. ; (Crakanthorp) 99; (Carleton) ro6; (Davenant) I ro; (Hall) I I2; (Usher) I2I ; (Taylor) I28, I3I, I33; (Laud) I46, I 48 foll.; (Heylin) r 53; (Mead) I 57 foll.; (Ferne) r6r; (Morton) I65 : (during the Commonwealth) I 70 foll. ; (Clarendon) I72 foll., I77 foll.; (Morley)
I76 ; (Thorndike) I84, I93 : (Bramhall) 205-209, 2I3, 2I5 ; (Cosin) 22I-232 ; (Gunning) 234; (Pearson) 24I ; (Parker) 255; (Scott) 257; (Pierce) 26I ; (Puller) 264 foll. ; (Croft) 268; (Sancroft) 270; (at the Revolution) 285, 288 foll. : (Tillotson) 286; (Comber) 293; (Stillingfleet) 307 ; (Burnet) 3I3, 3I6 ; (Hickes) 322-325, 326; (Brett) 329; (Leslie) 337; (Lindsay) 339; (Sherlock) 340; (Wake) 346 foll. ; (Sharp) 348 foll.; (Nichols) 358 foll.; (Bingham) 366 foll.; (Fleetwood) 372; (Waterland) 374, 376, 378 ; (Wesley) 407; (Van Mildert) 427, 43I foll.; the ordinations in them, $5 \mathrm{I} 2$ foll.

Clarendon, I7I foll., 220, 23I, 509

Comber, 290 foll.

Comenius, $18,5^{\text {I } 5}$

Comprehension, 272, 28I, 284

Cosin, 79, 89; on episcopacy, 218 foll.; his account of English catholicism, 220 ; resentment against Roman Catholics, 22I, 232 ; communion with French protestants, 222 foll.; considers presbyterian orders valid, 224 foll. ; thinks that they were formerly recognized in England, 224, 229, 508; his will, 23I ; his episcopal action, 232 ; his connexion with Sancroft, 269; his grave, 48I

Crakanthorp, 89 foll.

Cranmer, his appeal, 2 ; on the three orders, 24 ; on apostolic succession, 24; referred to, 307,328

Croft, his Naked Truth, 266 foll.

Daubeny, Charles, 4I 4 foll.

Davenant, John, Io8 foll.

De Laune, 79, 505

Denmark, the church of, I62, $215,336,421,436,520$ 
Dodwell, 33I foll.

Dort, synod of, 20, 105 foll., I I 8 , 484

Downham, George, 65

$\mathrm{Du}$ Moulin, the elder, 66, 69, I 55 ; the younger, 506,525

Durel, 1 70, 172, 223

Dury, John, 88, I I0, I34, I5I, I57, I59, 484; reordained, 229, 505

Episcopacy, bound up with the catholic tradition, I, 20 ; endeared to Englishmen by the Marian martyrdoms, 23, 8I ; by those of Laud and Charles I, I67; traced to the apostles by the authoritative formularies of Anglicanism, 24; by Cranmer, 24 ; by Whitgift, 27 foll.; by other Elizabethan divines, 3o, 31,37 foll., 40 ; by Bancroft, 45 ; by Bilson, 47 ; by Hooker, 55 foll. ; held to be necessary to the existence of a church by Saravia, 34 ; apparently by Hall, II 7 ; by Taylor, I29; by Laud, 146, 148 ; by Mountague, $\mathrm{I}_{52}$; by some at the Restoration, 178 ; apparently by Gauden, I98 ; by Barrow, 245; by Beveridge, 298 ; by Hickes, 323 ; by Brett, 329 ; by Hughes, 362 ; by Daubeny, 4I 5,421 ; by Van Mildert, 430 ; by Heber, 434 ; the contrary affirmed by Hooker, 59 ; by Andrewes, 70 ; by Forbes of Corse, I04; by Usher, 122; by Ferne, 162; by Morton, 165; by Thorndike, 184, I86; by Bramhall, 206, 21 5 ; by Cosin, 228; by Saywell, 236; by Samuel Parker, 255 ; by Scott, 259 ; by Puller, 265 ; by Croft, 268; by Leighton, 275 ; by Burnet, 3I3, 316; by Sherlock, 340 ; by Thorp, 344

Ferne, I 59 foll.
Fiddes, 396 foll.

Field, his catholicism, I 3 ; on identity of bishops and presbyters, 6r foll.

Fleetwood, 370 foll., 509, 537

Forbes, John, of Corse, Ioo foll.

France, reformed churches in, 524 foll.

Fulke, William, 3 I

Fuller, misrepresents Cosin, 222

Gauden, I 95 foll.

Germany, reformed churches in, 522 foll.

Gilpin, Bernard, 106

Goode, William, 22, $45^{\circ}$

Graham, bishop of Orkney, II 2

Grotius, 18, 80, 213, 266

Grove, 547

Gunning, correspondence with Cosin, 228, 232; his principles described by Saywell, 233 foll.; referred to, 3I $\dot{9}$

\section{Hacket, 147}

Hall, Joseph, II I foll. ; requests Usher to write on episcopacy, II8; correspondence with Laud, 145 ; on foreign orders, 507

Hammond, r 34 foll.

Harington, 25

Hatch, Edwin, 452 foll.

Heber, 433 foll., 5 Io

Heylin, 72 ; assails Usher, 123; on episcopacy, I52; Cosin writes to him, 222

Hickes, his change of views, 322 ; his appeal to foreign protestants, 323 foll. ; on the Scotch presbyterians, 324,325 ; on Burnet's views, 326

Homilies, Books of, their catholicism, 7

Hooker, his catholicism, II ; on presbyterianism, 53, 54; on the reformed churches, 53; on episcopacy, 55 foll. ; on extraordinary vocations, 60

Horne, George, bishop of Norwich, 4 IO 
Horne, Robert, bishop of Winchester, 8

Horsley, 4I I foll.

Hughes, 360 foll.

Hutton, Matthew, 30, 495

Jablonski, 349, 5I6

Jane, 286

Jebb, John, 442 foll.

Jewel, his challenge, 4 ; on episcopacy, 25 foll.

Jones, William, of Nayland, 4II , 4I 3

Jus divinum, its different senses, $65,68,70,92, I_{42}$ foll., I44, $229,230,250,300,305$

King, Peter, 406

Knox, Alexander, 44I

Knox, John, 526

Laud, his letters to Hall, I45 ; " no bishop, no church," I 49 ; the foreign churches, I 49 foll. ; his martyrdom, I67

Law, his Three Letters, 384 foll.

Leighton, 274 foll.

Leslie, 335 foll.

Lightfoot, 463 foll.

Lindsay, 89, 339

Lloyd, William, on the fabled presbyterianism of Scotland in early ages, IO4

Macaulay, referred to, 25, 29

Maddox, 400 foll.

Martyrs, English bishops, 23, 8I

Mason, Francis, 80 foll.; on foreign orders, $8 \mathrm{I}, 89$ foll.

Mead, Joseph, I 56

Moravians, the, see Unitas Fratrum

Morison, 496

Morley, I 7I, I 76

Morton, I 63 foll.

Mountague, I 49, I5I

Nichols, $35^{8}$ foll.

Nonconformists, 278,530 ; ordination amongst them, 528 foll.
“Occasional conformity," 278, $329,488,536$ foll., 542 foll.

"Occasional separation," 4 I8, 426

Orders, may in some cases be dispensed with, $182,185,188$

Ordinations per saltum, 72

Overall, Convocation Book, 73 ; accepts foreign presbyterian orders, 79, 505; share in Mason's work, 89; connexion with Cosin, 89, 218, 230, 232

Parker, archbishop, approves of Jewel's $A$ pology, 4 ; his Declaration, 8 ; his consecration, 25 ; on foreign protestants, 483 , 485

Parker, Samuel, his Erastianism, 25I; on the divine right of episcopacy, 253; on protestantism, 255 ; on the foreign churches, 255

Patrick, shows that the English church never recognized presbyterian orders, 249 foll.; on separation, 279; Comber's letter to, 290

Pearson, on episcopacy, 237 foll.; on apostolical succession, 240 ; on promiscuous ordinations, 240 foll. ; referred to, 319

Phillpotts, Henry, 288, 449

Pierce, Thomas, 26I foll.

Potter, his Discourse of Church Government, 35I foll.; befriends the Moravians, $5 \mathrm{I} 6$

Presbyterian orders held invalid, I09, I2I, I28, I4I, I66, I68, I 76, I93, 20I, 243, 249, 284, $293,296,326,330,333,350$, $355,363,370,376,377,378$, $382,383,393,397,398,433$, 487

Prideaux, Humphrey, $31 ;$ foll.

Protestantism, a word of doubtful meaning, 209, 226, 255 , 264,285 foll., $405,417,446$

Puller, Timothy, his Moderation of the Church of England, 263 foll., 43I 
Reordination, conditional or otherwise, 71, 79, 130, I76, I 77 foll., 217, 224, 229, 249, $274,283,284,288,289,290$, 368, 37 I foll., 383,436

Robinson, John, bishop of London, $5^{19}$

Sage, 134

Sancroft, on episcopacy, 269; on foreign churches, 270 ; attitude to dissenters, $27 \mathrm{I}$ foll.; his comprehension scheme, 272 foll.

Sanderson, I4, foll., I69

Sandys, 494 foll.

Saravia, on episcopacy, $3 x$ foll. ; his hopes for catholic reformation, 42 ; his view of the reformed churches, 42 ; his ordination, 502 foll.

Saywell, on the communion between English and foreign churches, 234 foll.

Schism, the church of England on, 534 foll. ; (Jewel) 4 foll. ; (Saravia) 34 ; (Taylor) 133 foll.; (Ferne) I62; (Thorndike) I81 foll., 185, I87, I89, I92 ; (Gauden) 198, 202 foll. ; (Bramhall) 208 foll.; (Gunning) 235; (Scott) 258 foll.; (Puller) 264 foll.; (Comber) 290 foll. ; (Beveridge) 298; (Stillingfleet) 302, 303; (Burnet) 31 7; (Hickes) 323; (Brett) 329 foll.; (Dodwell) 33I ; (Leslie) 337 ; (Sherlock) 342, 548 foll.; (Thorp) $344 ;$ (Potter) 35r, 358; (Fleetwood) 372; (Waterland) 374 ; (Smalridge) $38 \mathrm{I}$; (Wesley) 408 foll.; (Daubeny) 4 I6 foll.; (Van Mildert) 427 foll., 432

Scotland, the presbyterian church of, 53,70, IO $_{4}, \mathrm{II}_{2}, \mathrm{I}_{4} 6$, $212, \quad 275, \quad 291, \quad 293, \quad 323$, $324,325,329,371,372$, 526

Scott, John, on the church, 256 ; on episcopacy, $25^{8}$ foll. ; on ordination, 26o; against hypothetical reordination, 288

Scudamore, I 75

Secker, 403 foll.

Separatists, 279

Sharp, abp of York, 288, 33I, 348 foll.

Sherlock, William, 340 foll. ; on schism, 548

Sikes, Thomas, $4^{2} 3$ foll.

Skelton, Philip, 438 foll.

Smalridge, 378 foll.

Spotswood (or Spottiswood), 70 foll.

Stackhouse, 399 foll.

Stillingfleet, his Irenicum, 300 foll.; his recantation, 310 ; his influence on Hickes, 322 ; on Wesley, 408; his Unreasonableness of Separation, 309 ; referred to by Dodwell, 333

Succession, the apostolical (Cranmer) 24 ; (Fulke) 3I ; (Sutcliffe) 40 ; (Bancroft) 46 ; (Bilson) 49 foll. ; (Hooker) 56, 60 ; (Andrewes) 68; (Overall) 74, 76; (Mason) 81, 83, 84; (Carleton) 107; (Davenant) I09; (Usher) II9; (Taylor) I24; (Hammond) I 38 foll.; (Sanderson) I44; (Mountague) I52; (Morton) I64; (Thorndike) I84, I87 foll., I94; (Gauden) 199, 202 ; (Bramhall) 203 foll., 2 I 4 ; (Cosin) 218 foll., 223; (Pearson) 240, 242 ; (Barrow) 248; (Scott) 258, 260; (Beveridge) 294 foll.; (Cave) 300 ; (Stillingfleet) 307, 310; (Burnet) 3I3 foll.; (Prideaux) 320; (Hickes) 324; (Brett) 330; (Dodwell) 332 foll. ; (Leslie) 335, 338 ; (Thorp) 344 ; (Bonnet) $35^{\circ}$; (Potter) 353; (Nichols) 360 ; (Hughes) 362 ; (Waterland) 376 ; (Smalridge) 379 ; (Wilson) 382 ; (Law) 384-395 ; (Fiddes) 397; (Stackhouse) 399; (Wesley) 
406 ; (Horne) 410 ; (Jones) 4II, 4I3; (Daubeny) 4I6, 420 foll. ; (Sikes) 423; (Van Mildert) 429; (Heber) 437; (Skelton) 439; (Jebb) 442 ; (Phillpotts) 449; (Lightfoot) 480 Sutcliffe, Matthew, 40

Sweden, the church of, 162, I95, $215,336,421,436,517$ foll.

Taylor, Jeremy, 123; on the foreign churches, I 28 foll. ; on communion with them, 133

Tenison, 290, 545

Thorndike, on the primitive polity, I8o; excuses foreign protestants, I8I, I84 foll. ; distinguishes between them, I93 : admiration for the Bohemian Brethren, I94; his views on English dissenters, 187; thinks the church has power to overlook defects of ordination, 188 ; no communion to be held with dissenters, I69, 188 foll. ; on catholicism and the English church, I89 foll. ; on Romanism, I92; requires repudiation of schism, I93 Thorp, 343 foll.

Thwaites, 497

Tillotson, 282 foll. ; anecdote of, 287

Toleration, 277,280
Townsend, 497

Travers, 497 foll., 507

Unitas Fratrum (the Bohemian Brethren, or Moravians), I8, I62, I94, 2I 5, 234, 28I, 349, $5 \mathrm{I} 4$ foll., $54 \mathrm{I}$

Usher, 118 ; his Reduction, I20 ; on the foreign churches, I2I foll. ; requests Hammond's aid, I 37

Van Mildert, 427 foll.

Wake, his account of Sancroft's comprehension scheme, 272; his controversy with Bossuet, 345 ; his correspondence with the Gallicans, 346 foll. ; a patron of the Moravians, 516

Waldensians, the, I94, 428, 512 foll., 5 I 5

Ward, Samuel, i 8

Waterland, 373 foll.

Wesley, John, 406 foll., 4Io foll., 425,433

Whitgift, on episcopacy, 26 foll. ; on Whittingham's case, 495 ; on Travers, 498 foll.

Whittingham, 229, 493

Williams, archbishop, I47

Wilson, Thomas, $3^{81}$ foll.

Zinzendorf, 516 


\title{
SELECTION FROM THE GENERAL CATALOGUE
}

\author{
OF BOOKS PUBLISHED BY \\ THE CAMBRIDGE UNIVERSITY PRESS
}

The Sufficiency and Defects of the English Communion Office. By A. G. Walpole Sayer, B.D. Crown 8vo. $3^{\text {s net. }}$

The Liturgy of the Primitive Church. By R. M. Woolley, B.D. Crown 8 vo. 5 s net.

The Bible of To-day. By the Rev. Alban Blakiston. Large crown 8 vo. $3^{\text {s net. }}$

Early Latin Hymnaries. An index of Hymns in Hymnaries before r roo. With an appendix from later sources. By James MEARns, M.A., Vicar of Rushden, Buntingford. Demy 8vo. With a frontispiece. 5s net.

The Canticles of the Christian Church Eastern and Western in Early and Medieval Tines. By the same author. Demy 8vo. With 3 plates. 6s net.

St Basil the Great. A Study in Monasticism. By W. K. Lowther Clarke, B.D., formerly Fellow of Jesus College, Cambridge, Rector of Cavendish, Suffolk. Demy 8vo. $7 \mathrm{~s} 6 \mathrm{~d}$ net.

The History of the Islands of the Lerins. The Monastery, Saints and Theologians of S. Honorat. By A. C. Cooper-Marsdin, D.D., Honorary Canon of Rochester. Demy 8vo. With 15 plates. ros $6 \mathrm{~d}$ net.

Saint Theresa. The History of her Foundations. Translated from the Spanish by Sister AGNes Mason, C.H.F. With a preface by the Right Hon. Sir E. M. Satow, G.C.M.G. Crown 8vo. With 11 illustrations and map. $4 \mathrm{~s} 6 \mathrm{~d}$ net.

Church Life and Thought in North Africa, A.D. 200. By Stuart A. Donaldson, D.D., Master of Magdalene College, Cambridge. Crown 8vo. 5 plates. 3 s $6 \mathrm{~d}$ net.

Paganism and Christianity in Egypt. By Philip David SCOTT-MonCRIEFF, M.A. Crown 8vo. With a frontispiece. 6s net.

The Historic Church. An Essay on the Conception of the Christian Church and its Ministry in the Sub-Apostolic Age. By J.C. V. DUReli, B.D. Crown 8vo. 5s net.

The Early English Dissenters in the Light of Recent Research (1550-164I). By Cham plin Burrage, Hon. M.A. (Brown University), B.Litt. (Oxon). In two Volumes. Illustrated. Volume I. History and Criticism. With 5 illustrations. Volume II. Illustrative Documents. With 5 illustrations. Demy 8vo. zos net. 


\section{THE CAMBRIDGE HANDBOOKS OF LITURGICAL STUDY}

General Editors: H. B. Swete, D.D., and J. H. Srawley, D.D.

The Ancient Church Orders. By Arthur John Maclean, D.D., Hon. D.D. (Glasgow), Bishop of Moray, Ross and Caithness. Small crown 8vo. 4 s net.

The Church Year and Kalendar. By John Dowden, D.D., Hon. LL.D. (Edinburgh), late Bishop of Edinburgh. Small crown 8vo. 4 s net.

The Early History of the Liturgy. By J. H. SRawley, D.D., Examining Chaplain to the Bishop of Lichfield. Small crown 8vo. 6s net.

The Offices of Baptism and Confirmation. By T. Thомpson, M.A. Small crown 8 vo. 6 s net.

\section{THE CAMBRIDGE DEVOTIONAL SERIES}

Prices for each volume, Cloth, is $6 \mathrm{~d}$ net; White Cloth extra, 2s net; Lambskin, 2s $6 \mathrm{~d}$ net.

Selections from the Confessions of St Augustine. Newly translated by W. MONTGOMERY, B.D.

Saint Bernard, Abbot of Clairvaux. Selections from his letters, meditations, sermons, hymns and other writings, rendered into English by Horatio Grimley, M.A.

The Imitation of Christ; or, The Ecclesiastical Music. By Thomas ì Kempis. An English translation edited by J. H. Srawley, D.D.

Saint Francis and his Friends. Rendered into English from Franciscan Chronicles by Horatio Grimley, M.A.

Blaise Pascal. Thoughts. Selected and translated by Moritz KaUfmanN, M.A.

The Interlinear Psalms. The Authorised Version and the Revised Version, together with the Marginal Notes of the Revised Version.

The Sermons of Thomas Adams, the Shakespeare of Puritan Theologians. A selection edited by JOHN BRown, D.D.

The Sermons of Henry Smith, the Silver-tongued Preacher. A selection edited by JoHn Brown, D.D.

Agathos, The Rocky Island, and other Sunday Stories and Parables. By SAMURL WILBERForCE. With an introductory note by A. J. MASON, D.D.

\section{Cambridge University Press}

C. F. Clay, Manager: Fetter Lane, London 
DATE DUE

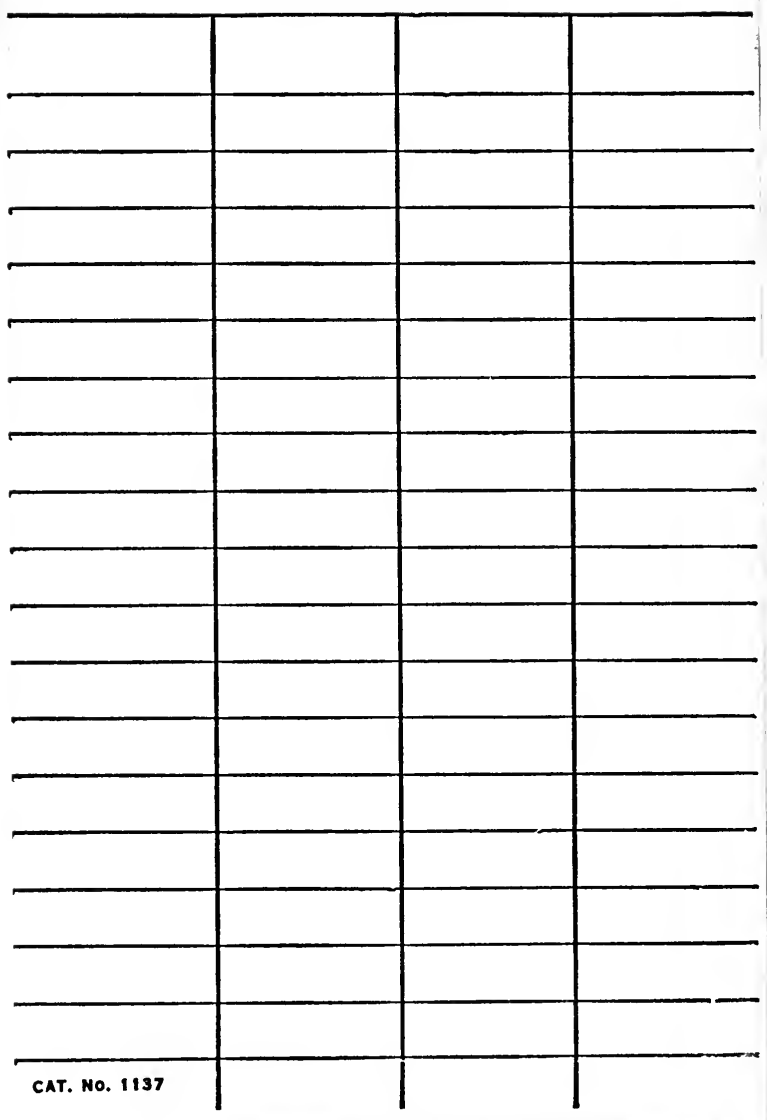




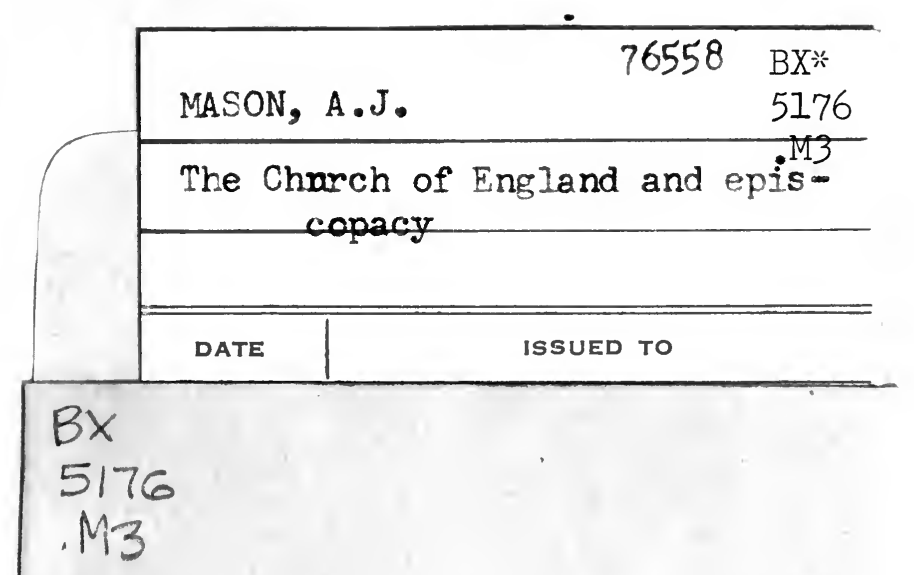


a.

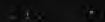

